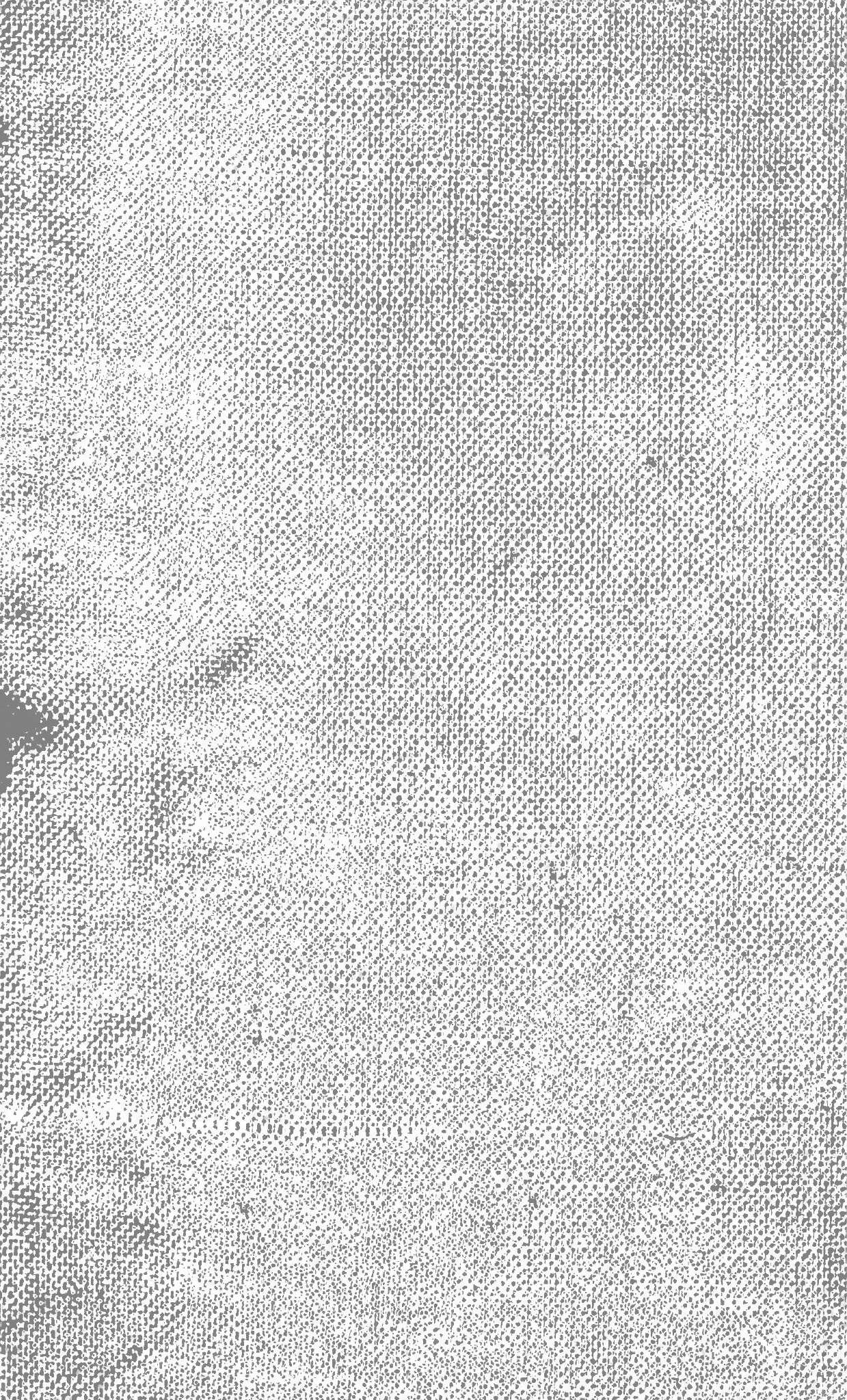




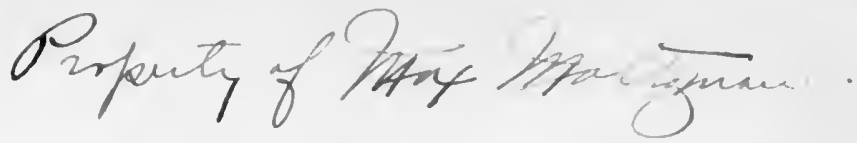

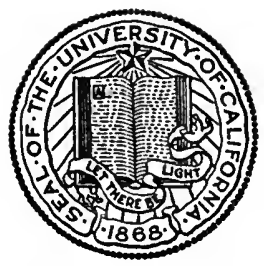

THE LIBRARY

OF

THE UNIVERSITY

OF CALIFORNIA

LOS ANGELES

SCHOOL OF LAW

\author{
GIFT OF \\ John Hogan
}



Digitized by the Internet Archive in 2007 with funding from Microsoft Corporation 


\title{
The Law of \\ Architecture and Building
}

A Consideration of the Mutual Rights DUTIES AND LIABILITIES OF ARCHITECT OWNER AND CONTRACTOR, WITH APPENDICES AND FORMS.

\footnotetext{
BY

CLINTON H. BLAKE, JR., A.B., A.M., LL.B. of the Nerw York and Federal Bars
}

\author{
WITH A SPECIAL INTRODUCTION BY \\ AYMAR EMBURY II \\ Member \\ American Institute of Architects
}

NEW YORK

THE WILLIAM T. COMSTOCK CO. 


$$
\frac{T}{1916} 2
$$

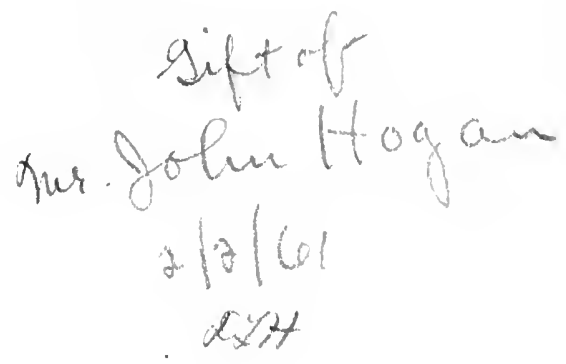

Copyright, 1916

By CLINTON H. BLAKE, JR 
To

M. C. B. 



\title{
SPECIAL INTRODUCTION
}

\author{
By Aymar Embury II., \\ (Member American Institute of Architects.)
}

Architects as a class are indisputably earnest and careful in their work, but very properly devote the most part of their attention to construction and design. The business end is to most of us incidental, and while we try to keep our accounts straight and our contracts in form, our legal rights and obligations and the legal rights and obligations of our clients and contractors receive far less consideration at our hands than they should.

Because of the attention which we pay to the construction, we do not very often erect unsafe buildings, but our handling of the legal and business end of our work has not been commensurately good. If we do not have more trouble with our contractors, our owners or our Building Departments, it is because of their complacence, and not because of our understanding of sound legal and business principles.

Conscious violations of the building law by architects are not frequent, yet they are by no means uncommon, and are often forced by the poorly written and untechnical statutes of many of our States. In my home town for example, 
the building code for many years provided that all cement mortar should be mixed with long catthe hair: of course that particular section of the ordinance was violated as often as there was a building erected in the town, and yet what else could be done?

However, ignorance of the building code does not as a rule bring as serious consequences upon the head of the architect as does ignorance of the rather unusual quasi-judicial position which he occupies, and that more architects do not get into very serious trouble is probably more due to the complacence of their clients, than to the correctness of the positions assumed by the architects. As a matter of fact this book came to be written because Mr. Blake, acting as my attorney, discovered that I had very curious and false notions of my duties and responsibilities, and finding that the clients for whom I worked, had other views equally curious and untenable, the idea naturally suggested itself that brief and authoritative statements of the law in its relation to architect and client alike, would be valuable.

Another thing which makes such a hand book almost a necessity is that a copy of the laws would not help much, even if one took the time and trouble to wade through a young library of "Acts" to find the ones which concern building and building contracts. The law is made as much by the interpretations placed upon it by various judges, as by its letter; and the judicial precedents and interpretations established in the different juris- 
dictions are of vastly more importance than the mere texts of the statutes alone.

Of course I am writing from the standpoint of the layman, and without much real knowledge of the abstruse workings of the legal mind; but that is the way it seems to me. Therefore I wish to find out just what I ought to do to protect myself from my client and to protect my client from my builder. In case of trouble I must go to a lawyer, unless from previous cases of similar kind I have gathered a knowledge of the proper steps to take; it is certain that I will not go to a lawyer until I find myself in trouble, and then I may find that I have done all sorts of things which I ought not to have done, and left undone those things which I ought to have done, and there is no health in my case. Yet a little care and foresight and especially a little knowledge would have kept me from doing things (to a lawyer) obviously foolish and even criminal.

Most architects do not at all know how much authority is conferred upon them, and most clients do not know either, so that, depending upon the temperament of the architect and of the owner, in some jobs the architect becomes a mere servant, who has to carry out the owner's mandates without regard to contractual limitations, while in other jobs the architect becomes a sort of petty dictator, whose statements are accepted by the owner and the builder as final and binding.

This condition of affairs exists-and can only continue to exist-because of the very complete 
ignorance on the part of the owner and of the architect as to the exact status of their relations. Most of us perhaps are willing to usurp authority if we think no ill will follow, but most of us also would be very careful if we knew that such usurpation might have the most unpleasant financial consequences. The architect can afford neither to be the tool nor the boss of his client, and he should be able to proceed with his work with fairness to the owner and to the builder, and without fear that in the exercise of his authority, he may become liable to discharge without compensation.

I think most architects have more trouble with clients than they do with builders. This is perhaps only natural, since builders are in the business all the time and know the ropes, at least in a general sort of way, while a very great majority of owners are building for the first and only time, and have very little knowledge of what they are undertaking when they sign a contract, or even when they ask an architect for sketches.

The question of the architect's liability is something that most architects do not understand at all. I was very greatly surprised to learn that I had no authority to alter the definite letter of the specifications or allow any departure from the terms of the contract without the consent of the owner. Prior to the receipt of this information I had probably never constructed a building in which the specifications were literally adhered to, and it is also possible that I have not constructed 
one since; but at least I have been careful to see that I permitted no changes, without the owner's consent, which would cost any very great amount to alter back to conform with the original specifications.

Probably most architects do permit minor changes which result in the betterment of the job, or which make things easier for the contractor without detriment to the job, and for which there is no extra asked or expected. Architects are accustomed to use their own judgment in making these changes, and most clients are willing to accept the architect's judgment on such points. However when a careful client, over zealous for his own interest, discovers that such a change has been made, over his head, as he thinks, he is apt to place the worst possible construction upon it. $\mathrm{He}$ can if he likes, insist upon work being done in exact accordance with the original contract and it may cost the architect a lot of money to do it.

I remember in one of my own jobs, I had specified that nothing but galvanized nails should be used in the exterior trim; in some way the clause slipped by the contractor (I do not think there was any ill intention on his part) and a very considerable portion of the exterior trim was applied to the house, between inspection visits, with ordinary nails. To remove these nails would have destroyed the trim, and would have resulted in the loss to the contractor of a very considerable sum. Furthermore it would have taken from 
four to six weeks to secure new trim, and have delayed the job sufficiently to mean extreme discomfort to the owner. I did what I thought fair and best; had the nail heads well set in and puttied at once, and galvanized nails added in sufficient number to hold the trim. I am informed that by this act I assumed a rather grave responsibility, yet I hardly see that any other action would have been beneficial to the job. I know now that I should have secured the prior consent of my client in order to clear myself of any possible financial responsibility.

It is cases like this that have made me extremely glad to have this book of Mr. Blake's to read over. In the first place I am going to fix the general principles of the law in its relation to the architect, builder and owner, firmly in mind, and in the second place by use of the index I can discover what I should do in any particular case where there is a possibility of trouble arising. Of course in a case of actual trouble, I shall still go at once to my lawyer, but I shall be able to go with my record absolutely clear, and with the certainty that both the law and its interpretation will be on my side.

Aymar EMBURy II.

New York City, October, I9I5. 


\section{AUTHOR'S PREFACE}

During the years I9I3-I4 I contributed to Architecture a series of articles the purpose of which was to define and set forth, in comparatively simple and yet practical form, the respective rights, duties, and liabilities, of architect, owner, and contractor.

The request for the preparation of these articles was born of the realization by the publishers of Architecture of the fact that, among architects especially, the legal rights and liabilities affecting the architectural profession were, in general, neither appreciated nor understood, and of the desire to place before them a statement of the basic rules of law governing and affecting the practice of their profession, in a form which would be at once sufficiently free from special legal phraseology to be understood by a layman, and at the same time sufficiently comprehensive and detailed in the citation of cases to enable the reader to refer to the leading cases if desired.

The desire which has been expressed that the articles contributed to Architecture be published in a fuller and more detailed form, and in a form available for general reference and office use, is the raison d'etre of the present volume. The text has been enlarged and revised and additional cita- 
tions of recent decisions added. There has been added, also, a table of cited cases and a number of special appendices and forms.

My endeavor, in general, has been twofold: First, to provide a text which will enable the architect, owner, or contractor, to understand or readily ascertain his respective duties and liabilities, and the elementary and general legal rules which govern them; second, to make the discussion of the various points treated sufficiently detailed and technical so that it may be of aid to the legal, as well as to the architectural, profession. For this reason, especially, the citation of authorities has been made as thorough and as comprehensive as possible.

There will be found collected, in considerable number and detail, citations of authorities covering the various matters referred to, and illustrative of the manner in which they have been treated and passed upon by the courts of the several States and especially by the courts of New York, by the Federal courts, and by the courts of other countries. The cases cited have been personally checked and verified and an earnest endeavor made to insure their accuracy, both in citation and in application.

There are certain broad and many less broad but none the less vital principles, governing the rights, duties and liabilities, of architect, owner, and contractor, which it is essential they should understand, if they are to be able to deal with one another with a minimum amount of legal contro- 
versy, and with a proper and desirable degree of mutual understanding and satisfaction. The general right of the architect to compensation, the ownership of plans, the right to charge for preliminary sketches and preliminary work, the respective rights of the parties under the lien laws of the various States, the ever troublesome questions of estimated cost, extras, alterations in plans and superintendence-all of these are matters which, to one acquainted with the broad general legal principles by which they are governed, will present no great amount of difficulty but, to another not so warned and forearmed, will present almost innumerable opportunities for serious financial loss, unnecessary and expensive litigation, misunderstandings with clients, architects, or contractors, as the case may be, and a very considerable amount of entirely unnecessary worry and difficulty.

Part I of the text deals with the relationship and the mutual rights and liabilities of the architect and the owner.

Part II deals with the relationship and the mutual rights and liabilities of the owner and the contractor.

Part III deals with the matter of liens, including the lien rights of the architect, of the contractor, and of the subcontractor.

Part IV deals with the relationship and rights and liabilities of the architect and the builder, so far as they are not necessarily referred to and discussed under the prior headings, and contains a 
general summary of the more important points in the text, from the point of view, especially, of the architect, together with general suggestions based thereon.

The Appendices contain a number of selected decisions in leading cases for general reference reading supplemental to the text, the new Standard Documents, Forms, Canons of Ethics, and Schedule of Minimum Charges of the American Institute of Architects, and the Schedule of Charges of Architects, as approved by the New York Chapter of the American Institute.

The special forms which follow Appendix E are adapted from forms used in actual court proceedings. They include a number of the more useful and more generally needed forms in lien actions. It has been thought unnecessary to encumber the text with all the forms required from time to time in such proceedings, in view of the many excellent forms already published, and the fact that it is not the purpose of the present text to deal exhaustively with the subject of liens, but rather to emphasize those points therein which are especially applicable to the mutual relations of the architect, the owner, and the contractor.

For special or more detailed investigation as to any particular point in the text, reference may be had to the special authorities dealing with that point alone, as distinguished from the general subjects which it is the purpose of the present pages to discuss.

I wish to acknowledge my indebtedness in gen- 
eral to all of the standard legal digests and encyclopedias, and to the various authors to whom I have endeavored to give full credit in the reference notes. I must acknowledge, especially, the courtesy of The American Institute of Architects, in granting to me permission to publish the Standard Documents, Forms, Canons of Ethics and Schedule of Minimum Charges issued by the Institute and which comprise Appendix B. A similar acknowledgment is due the New York Chapter of the American Institute for the permission granted to publish its Schedule of Minimum Charges.

If the following pages prove helpful in any way to my many good friends in the Architectural profession or to my fellow-members of the Bar, I shall feel amply repaid for the time and effort given to their preparation.

Clinton H. Blake, Jr.

New York City, October I5th, I9I5. 



\title{
TABLE OF CONTENTS.
}

\author{
PART I. \\ THE ARCHITECT AND THE OWNER.
}

\author{
CHAPTER I. \\ THE RELATIONSHIP IN GENERAL. \\ [References are to Pages.]
}

$\S$ 1. Similar to Other Professional Relationships......... 3

§ 2. Exceptions to Rule........................... 3

$\S$ 3. Absolute Good Faith Required.................. 5

8 4. Architect to Have No Concealed or Conflicting Interest in Contract............................. 6

8. Limitation of Rule-Estoppel of Owner........... 9

$\S$ 6. Assumption of Good Faith..................... I0

CHAPTER II.

THE ARCHITECT AS AGENT OF THE OWNER.

8 7. Importance of Agency Relationship............. I2

8 8. Agency, Express and Implied.................. I2

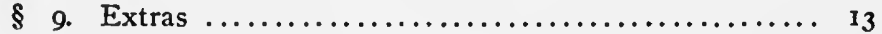

$\S$ Io. Illustrations of Rule....................... I8

$\S$ 11. Other Limitations on General Agency.............. 23

$\S$ 12. Special Agency-To be Carefully Exercised......... 25

\& 13. Estoppel of Owner.......................... 26

§ 14. Delegation of Powers-The General Rule........... 27

$\S$ 15. Limitation of Rule......................... 28

§ I6. Due Care Required in Delegation of Authority........ 30

$\S$ 17. Power to Act in Emergencies................... 31

$\S$ I8. Dangers of Implied Authority................. 32

§ 19. General Precautionary Suggestions.............. 33 xvii 
xviii

CHAPTER III.

THE COMPENSATION OF THE ARCHITECT.

$\S$ 20. Introductory $\ldots \ldots \ldots \ldots \ldots \ldots \ldots \ldots \ldots \ldots \ldots \ldots \ldots \ldots$

$\S 21$. Theory of Recovery-Contract and Quantum Meruit 37

$\S 22$. Recovery in Absence of Special Conditions or Agree-

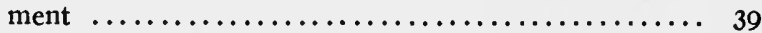

$\S 23$. Effect of Specified Conditions................... 40

$\S 24$. Conditions $\operatorname{Re}$ Cost........................ 40

$\S 25 . \quad$ Limitation of Rule.......................... 42

$\S 26$. Necessity of Delivery...................... 44

$\S$ 27. Delivery and Acceptance Distinguished............ 46

$\S 28$. Necessity of Actual Contract-Custom Alone Insuffcient to Sustain Recovery................... 47

$\S$ 29. Illustration of Rule........................ 48

$\S 30$. Competitions ............................. 52

§ 31. Proper Care and Skill Required................ 53

$\S$ 32. Modification of Contract...................... 54

$\S 33$. Rescission of Contract by Owner-Preliminary Sketches ............................. 55

$\S 34$ Illustration of General Rule................. 56

$\S$ 35. Cannot Compel Client to Complete.............. 57

$\S 36$. Measure of Damages on Refusal to Complete........ 58

$\S 37$. Basis of Computation of Value of Services......... 58

$\S 38$. General Suggestions...................... 6r

CHAPTER IV.

DUTIES AND LIABILITIES OF THE ARCHITECT.

§ 39. In General............................... 67

$\S 40$. Plans and Specifications....................... 69

$\$$ 4I. Mistakes ................................. 69

$\S$ 42. Negligence-Measure of Damages............... 69

$\S$ 43. Limitation of Rule-Architect not Liable if Plans Not Adhered To............................. 70

$\S 44$ Burden of Proof-Illustrations of Rule........... 70

\$ 45. Repairs and Superintendence................. 74

$\S 46$. Reasonable Care and Diligence Required-Illustrations of Rule........................... 75

$\S 47$. Negligence a Question of Fact................ 86

$\S 48$. Burden of Proof........................... 86

$\S 49$. Architect as Arbitrator........................ 86

$\S 50$. Certificates $\ldots \ldots \ldots \ldots \ldots \ldots \ldots \ldots \ldots \ldots \ldots \ldots, 87$ 
CHAPTER V.

DEATH OF ARCHITECT AND OWNERSHIP OF PLANS.

$\S$ 5r. Death of Architect........................ 89

$\S 52$. Ownership of Plans........................ 90

PART II.

THE OWNER AND THE CONTRACTOR.

CHAPTER I.

IN GENERAL.

$\S 53$. Introductory $\ldots \ldots \ldots \ldots \ldots \ldots \ldots \ldots \ldots \ldots \ldots \ldots . . \ldots 5$

$\S 54$. Compensation of Builder-Extras and Modification of Contract............................. 95

$\S 55$. The Architect's Certificate.................... I0I

\$ 56. Damages ................................ 107

$\S 57$. Right to Plans.......................... 109

$\S 58$. Liability of Contractor for Work of Subcontractor.... I Io

$\S 59$. Recoupment from Subcontractor................. iro

$\S 60$. Time of Payment.......................... II

§ 6r. Substantial Performance...................... III

CHAPTER II.

REQUISITES OF CONSTRUCTION CONTRACT.

$\S 62$. In General.............................. II

$\S 63$. Importance of Statutory Provisions.............. II7

$\S 64$. Void and Illegal Contracts................... II7

CHAPTER III.

TERMS AND OPERATION OF BUILDING CONTRACT.

§ 65. The Architect as Arbitrator................... II

$\S 66$. Limitation of Rule......................... I20

\$ 67. Extras ................................ 122

$\S 68$. Right of Owner to Complete.................. I24

$\S 69$. Suspension of Work by Mutual Consent.......... 125 
§ 70. Liquidated Damages........................ 125

§ 71. Contract Not to Usurp Jurisdiction of the Courts.... I30

CHAPTER IV.

"THE STANDARD DOCUMENTS."

$\S$ 72. In General.

PART III.

LIENS.

CHAPTER I.

IN GENERAL.

§ 73. Definition ............................. I39

\$ 74. History of Lien Legislation.................. 140

§ 75. Early Conception and Development of Doctrine...... I4I

$\S 76$. Constitutionality ......................... $\mathbf{r}_{42}$

$\S$ 77. Lien a Statutory Remedy..................... I43

\& 78. No Personal Liability......................... I44

$\S 79$. Necessity of Contract...................... 144

CHAPTER II.

THE LIEN OF THE ARCHITECT.

\& 80. Development of Doctrine..................... 147

§ 8I. Importance of Superintendence.................. I48

$\S 82$. The New York Doctrine..................... 150

§ 83. The Massachusetts Doctrine.................. I5.I

\$ 84. The Doctrines Contrasted-Discussion............. 154

§ 85. Reference to Particular Statute Essential........... I55

$\$$ 86. Lien by Contract............................ I55

$\S 87$. Lighting Fixtures............................ 156

$\S 88$. Consent of Owner......................... I57

CHAPTER III.

THE LIEN OF THE CONTRACTOR.

$\S 89$. Classes of Lienors......................... 160

$\S 90$. Various Statutory Provisions................. I62 
$\S$ 9r. Performance Must Be Proven................. I62

$\S$ 92. Substantial Performance Sufficient-Statement of the Rule .................................. I63

$\S$ 93. Effect of Delay............................ I6 64

§ 94. Limitation of Rule......................... 164

$\S$ 95. Necessity of Architect's Approval............... $16_{4}$

$\S$ 96. Municipal Contract-Approval by City Department as

Condition Precedent......................... 165

$\S$ 97. Collusion-Effect $\ldots \ldots \ldots \ldots \ldots \ldots \ldots \ldots \ldots \ldots \ldots \ldots$

$\S$ 98. Waiver of Condition by Owner................. I66

$\S$ 99. Certificate as Evidence of Performance............ I66

$\S$ roo. Corporations as Lienors...................... I67

$\S$ Ior. Effect of Fire............................ I67

§ro2. Change in Ownership........................ I68

$\S$ I03. Death of Owner............................ I68

§104. General Assignment......................... I68

$\S 105$. Consent of the Owner...................... I68

CHAPTER IV.

THE LIEN OF THE SUBCONTRACTOR.

$\S 106$. Nature of Lien............................ 170

\$107. The Pennsylvania Doctrine.................... 170

$\$ 108$. The New York Doctrine.................... 170

§rog. Failure of Contractor to Complete.............. I72

\$I I. Rights of Subcontractor as Affected by Contract..... I73

\$II . Employees and Material Men of Subcontractor...... I74

§I12. Necessity and Effect of Filing or Recording of Con-.

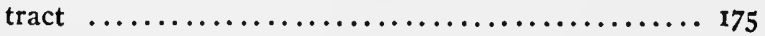

§ı13. Priority of Claims....................... 177

PART IV.

THE ARCHITECT AND THE CONTRACTORCONCLUSION.

\section{CHAPTER I.}

THE ARCHITECT AND THE CONTRACTOR.

§114. Rights and Liabilities in General............... I8

$\S$ II5. Right to Plans........................... I82 
xxii

TABLE OF CONTENTS

[References

CHAPTER II.

\section{CONCLUSION.}

§116. Summary and Final Suggestions............... 183

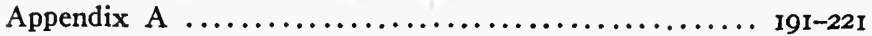

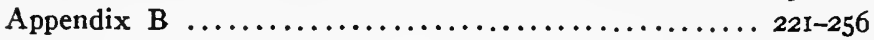

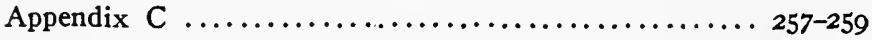

Appendix D ................................ 260-267

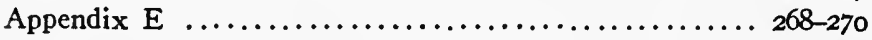

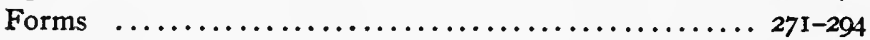

General Index ............................ 295-314

Index to Forms $\ldots \ldots \ldots \ldots \ldots \ldots \ldots \ldots \ldots \ldots \ldots \ldots \ldots \ldots \ldots \ldots, 3^{14}$ 


\section{TABLE OF CASES}

A.

\section{[References are to Pages.]}

Ada St. Methodist Episcopal Church v. Garnsey, 66 Ill. I32. . 42 Adlard v. Muldoon, 45 Ill. I93................... 18 Ahern v. Boyce, I9 Mo. App. 552...............13, 24

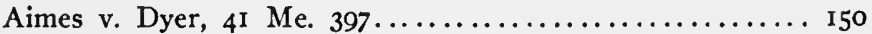
Aitken v. Wasson, 24 N. Y. $482 \ldots \ldots \ldots \ldots \ldots \ldots \ldots \ldots \ldots \ldots \ldots$ Allen v. Bowman, 7 Mo. App. $29 \ldots \ldots \ldots \ldots \ldots \ldots \ldots, 47$ Andrew Lohr Bottling Co. v. Ferguson, 223 Ill. 88, 79 N. E. 35106 Arnoldi v. Gouin, 22 Grant's Chan. (Ontario) 314 .......... I49 Atlantic, etc., Co. v. Donnelly, 59 N. J. L. $48 \ldots \ldots \ldots \ldots \ldots$ I 73 Atlee v. Fink, 75 Mo. 100, 42 Am. Rep. $385 \ldots \ldots \ldots \ldots \ldots$...... 7 Audsley v. The Mayor, 74 Federal $274 \ldots \ldots \ldots \ldots \ldots \ldots, 46$ Ayres v. Revere, 25 N. J. L. $474 \ldots \ldots \ldots \ldots \ldots \ldots \ldots \ldots$............ 176

B.

Badger v. Kerber, 6I Ill. $328 \ldots \ldots \ldots \ldots \ldots \ldots \ldots \ldots \ldots, 5$

Baird v. New York, 96 N. Y. $567 \ldots \ldots \ldots \ldots \ldots \ldots \ldots$........... 108 Baker v. Publishing Co. (Missouri I903), 77 S. W. $585 \ldots \ldots .55$ Ballon v. Black, 2i Neb. 131..................... I70 Baltimore Cemetery v. Coburn, 7 Maryland $202 \ldots \ldots \ldots \ldots$ I 8 Bank of Montreal v. Recknagel, I09 N. Y. 482.......... 73 Bank of Penn. v. Gries, 35 Pa. St. $423 \ldots \ldots \ldots \ldots \ldots \ldots$........ 150 Bannister v. Patty's Exec's., 35 Wis. $215 \ldots \ldots \ldots \ldots \ldots \ldots .28$ Barbee v. Findlay, 221 Ill. 25I, 77 N. E. 590............ 106 Barlow Bros. Co. v. Gaffney, 76 Conn. 107............. 174 Barry v. Cape, I5I Mass. $99 \ldots \ldots \ldots \ldots \ldots \ldots \ldots \ldots \ldots \ldots$ I 8 Bartlett v. Stanchfield, I48 Mass. $394 \ldots \ldots \ldots \ldots \ldots \ldots \ldots$ I 24 Baywater v. Richardson, I A. D. \& E. $508 \ldots \ldots \ldots \ldots \ldots$....... 50 Beckhart v. Rudolph, 68 N. J. Eq. 740, 68 N. J. Eq. 315 ..... I60 Belding v. Cushing, I Gray (Mass.) $576 \ldots \ldots \ldots \ldots \ldots \ldots$........ 145 Benner v. Schmidt, 44 Ill. App. $304 \ldots \ldots \ldots \ldots \ldots \ldots \ldots$ I6 4 Bennett v. Davis, Ir 3 Cal. 337.................... I6 I Berger v. Turnblad, 98 Minn. $163 \ldots \ldots \ldots \ldots \ldots \ldots \ldots$............ Bergfors v. Caron, 190 Mass. I68................. I63 Birmingham Iron Foundry v. Glen Cove Starch Manfg. Co., 78 N. Y. $30 . \ldots \ldots \ldots \ldots \ldots \ldots \ldots \ldots \ldots \ldots \ldots \ldots \ldots \ldots \ldots$ I I, I 43 xxiii 
Blauvelt v. Woodworth, 3I N. Y. $285 \ldots \ldots \ldots \ldots \ldots \ldots \ldots$ I43

Blinn Lumber Co. v. Walker, 129 Cal. $62 \ldots \ldots \ldots \ldots \ldots \ldots \ldots$ I75

Bliven v. New England Screw Co. 23 How. $420 . . . . . . . . .50$

Bloomington Hotel Co. v. Garthwait, 227 Ill. 6r3.......... I64

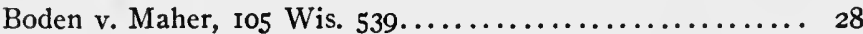

Bohem v. Seabury, I4I Pa. St. $594 \ldots \ldots \ldots \ldots \ldots \ldots \ldots \ldots$ I6 3

Bonagur v. Purificato, I46 N. Y. Supp. I070........... I I2

Bond v. The Mayor, etc., I9 N. J. Eq. 376........... 8,24

Bonestael v. The Mayor, etc., of N. Y., 22 N. Y. 162..... 24

Bonncy v. Ketcham, 5I Ill. App. 32I.............. I44

Booth v. Pendala, 88 Cal. $36 \ldots \ldots \ldots \ldots \ldots \ldots \ldots \ldots \ldots$ I43

Borup v. Von Kokeritz, I62 N. Y. A. D. $394 \ldots \ldots \ldots \ldots$ I03, I05

Bouton v. Supervisors of McDonough County, 84 Ill. $384 . .23,24$

Bowery National Bank v. The Mayor, 63 N. Y. $336 \ldots . . .$. I02

Brainard v. County of Kings, 84 Hun. N. Y. 290 , I55 N. Y.

$538 \ldots \ldots \ldots \ldots \ldots \ldots \ldots \ldots \ldots \ldots \ldots \ldots \ldots \ldots \ldots \ldots \ldots \ldots \ldots \ldots \ldots, 172, I 74$

Brandt v. City of New York, I Io N. Y. A. D. 396 , I86 N. Y.

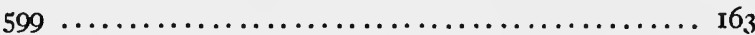

Brin v. McGregor (Tex. Civ. App. 1898) 45 S. W. 923..... 27

Brooks v. Railway Co., ror U. S. $443 \ldots \ldots \ldots \ldots \ldots \ldots \ldots$ I43

Brown v. Decker, I42 Pa. State $640 . \ldots \ldots \ldots \ldots \ldots \ldots \ldots$ II9

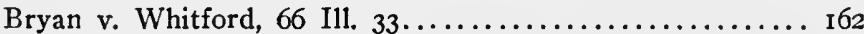

Brydon v. Lutes, 9 Manitoba $463 \ldots \ldots \ldots \ldots \ldots \ldots \ldots \ldots$. 63

Buckingham v. Flummerfelt, I5 N. Dak. I12......... I5I

Budd v. Lucky, 28 N. J. L. $484 \ldots \ldots \ldots \ldots \ldots \ldots \ldots \ldots$ I76

Burger v. Koelsch, 77 Hun. (N. Y.) $44 \ldots \ldots \ldots \ldots \ldots \ldots \ldots$ I 5

Burke v. City of Kansas, 34 Mo. App $570 \ldots \ldots \ldots \ldots \ldots \ldots 24$

v. Coyne, 188 Mass. $401 \ldots \ldots \ldots \ldots \ldots \ldots \ldots \ldots \ldots \ldots \ldots \ldots$

Bush v. Jones (C. C. A.), I44 Fed. $942 . \ldots \ldots \ldots \ldots \ldots \ldots \ldots$......... 06

Butler v. Flynn, 5I N. Y. A. D. $225 \ldots \ldots \ldots \ldots \ldots \ldots \ldots \ldots$ I59

Byard v. Holmes, 33 N. J. L. I $19 . \ldots \ldots \ldots \ldots \ldots \ldots \ldots \ldots$ I0 8

C.

Cairo, etc., Co. v. Watson, 85 Ill. 531............. I74

Campbell v. Day, 90 Ill. $363 \ldots \ldots \ldots \ldots \ldots \ldots \ldots \ldots \ldots$ i 8,23

Canfield (New England Monument Co.) v. Johnson, et al.,

I $44 \mathrm{~Pa}$. St. 6r, 22 Atl. 974............. 40, 46

Carlisle v. Knapp, 5I N. J. L. $329 \ldots \ldots \ldots \ldots \ldots \ldots \ldots \ldots$ I74

Carnegie Public Lib. Assoc. v. Harris (Tex. Civ. App. May

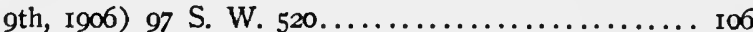

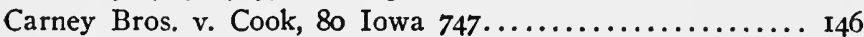

Cass County v. Gibson, I07 Fed. $363 \ldots \ldots \ldots \ldots \ldots \ldots \ldots$......... 107 
Central Trust Co. v. Richmond, etc., Co. 68 Fed. $90 . . . .$. I 170

v. Richmond, etc., Co. 54 Fed. $723 \ldots \ldots \ldots \ldots \ldots \ldots$. 174

Champlain Construction Co. v. O'Brien, II7 Federal 27I... II3

Chapman v. Faith, I8 Pa. Super. Ct. $578 \ldots \ldots \ldots \ldots \ldots \ldots$ I6I

Chapman Decorative Co., v. Security, etc., Co., I45 Fed.

434, I49 Fed. I89....................... I26

Chicago, etc., Co. v. Price, I38 U. S. $185 \ldots \ldots \ldots \ldots \ldots \ldots$ I2I

Clark v. Fry, I2I N. Y. $470 \ldots \ldots \ldots \ldots \ldots \ldots \ldots \ldots \ldots \ldots \ldots \ldots \ldots$

v. Marsiglia, I Denio (N. Y.) $317 \ldots \ldots \ldots \ldots \ldots \ldots, 58$

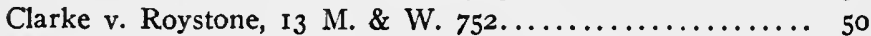

Cleveland, etc., Railroad Co. v. Moore, I70 Ind. 328....... I 6

Cobb v. Hatfield, 46 N. Y. $533 \ldots \ldots \ldots \ldots \ldots \ldots \ldots \ldots \ldots$. 108

Coburn v. Stephens, 137 Ind. $683 \ldots \ldots \ldots \ldots \ldots \ldots \ldots \ldots \ldots \ldots \ldots$

Cockerill v. Loonam, 36 Hun. (N. Y.) $353 \ldots \ldots \ldots \ldots \ldots$ I4I

Coddington v. Dry Dock Co., 98 Ala. 409............... I67

Coen v. Birchard, I24 lowa $394 \ldots \ldots \ldots \ldots \ldots \ldots \ldots \ldots . \ldots \ldots$

Coffin v. Reynolds, 37 N. Y. $640 \ldots \ldots \ldots \ldots \ldots \ldots \ldots \ldots . \ldots . \ldots$

Cole v. Clarke, 85 Me. $336 \ldots \ldots \ldots \ldots \ldots \ldots \ldots \ldots$....................

Commune de Calombier Saugnieu v. Duchez et Savoye, Dalloz

Jurisprudence Genérale, I883, part 3, p. $92 \ldots \ldots \ldots 24$

Condon v. Donohue, i6o Cal. $749 \ldots \ldots \ldots \ldots \ldots \ldots$............ I 17

Conner v. Lewis, r6 Me. $268 \ldots \ldots \ldots \ldots \ldots \ldots \ldots \ldots$ I75

Conners v. United States, I30 Federal $609 \ldots \ldots \ldots \ldots \ldots . .$. II

Cook v. Rome Brick Co., 98 Ala. $409 \ldots \ldots \ldots \ldots \ldots \ldots \ldots$......... I67

Coombs v. Beede, 89 Me. 187,36 Atlantic 104.... 3, 17, 44, 67, 75

Cooper v. Langdon, 9 M. \& W. (Messon \& Welsby) 60....18, 24

Coorsen v. Ziehl, ro3 Wis. $381 \ldots \ldots \ldots \ldots \ldots \ldots \ldots \ldots \ldots$. 145

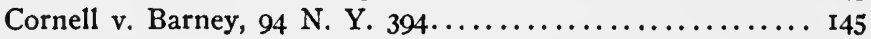

Costello v. Dale, I Hun. (N. Y.) $489 \ldots \ldots \ldots \ldots \ldots \ldots \ldots . \ldots . \ldots . \ldots$

Courtney v. Provincial Commission, 4I Nova Scotia 7I.... II9

Cox v. Broderick, 4 E. D. Smith (N. Y.) $721 \ldots \ldots \ldots \ldots \ldots$ I44

Crane Co. v. Hanley, etc., Co., 53 Mo. App. 540.......... I70

Crockett v. Chattanhoochen Brick Co. 95 Ga. $540 \ldots \ldots \ldots$.... I7

Crystal v. Flannelly, 2 E. D. Smith (N. Y.) $583 \ldots \ldots$ I44, I68

Culver v. Attwood, I70 Ill. $432 \ldots \ldots \ldots \ldots \ldots \ldots \ldots \ldots \ldots \ldots \ldots$

Cummings v. Consolidated, etc., Water Co., 6r Atlantic 353... I40

Curnew v. Lee, 143 Mass. 105................... I62

D.

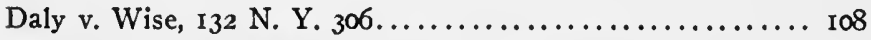

Danforth v. Tennessee, etc., Co., 93 Alabama 6r4........ I 24

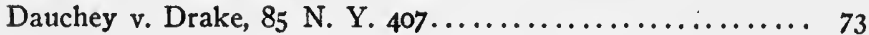

Davis v. Alvord, 94 U. S. $545 \ldots \ldots \ldots \ldots \ldots \ldots \ldots \ldots$. I 43 
David v. McDonald, 8 L. C. (Lower Canada) Jurist 44, I4

L. C. Rep. $31 \ldots \ldots \ldots \ldots \ldots \ldots \ldots \ldots \ldots \ldots$ 78, I07

Day \& Co. v. Pickens County, 53 South Carolina, $46 \ldots . .9$, I8

Delafield v. Sayre, 31 Vroom (N. J.) 449............. 144

DeLeon v. White, 9 Texas $598 \ldots \ldots \ldots \ldots \ldots \ldots \ldots \ldots \ldots$

Delray, etc., Co. v. Keohone, I32 Mich. 17.......... I73

Derr v. Kearney, 46 Misc. (N. Y.) $148 \ldots \ldots \ldots \ldots \ldots \ldots \ldots$

Dersheimer v. Maloney, I43 Pa. St. $532 \ldots \ldots \ldots \ldots \ldots \ldots$ I74

Diehl v. Schmalacker, 26 Misc. (N. Y.) $835 \ldots \ldots \ldots \ldots \ldots$. . . . 2

Dillon v. City of Syracuse, 5 Silv. Supreme Court (N. Y.)

575, 9 N. Y. Supp. 98,29 N. Y. St. Rep. $912 . \ldots \ldots$ I7

Disken v. Herger, 73 N. Y. A. D. $453 \ldots \ldots \ldots \ldots \ldots \ldots$ II 5

Dodge v. McDonnell, I4 Wis. $553 \ldots \ldots \ldots \ldots \ldots \ldots \ldots$ I 18

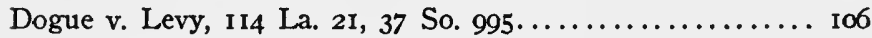

Drew v. Mason, 8I Ill. 498....................... I62

Dreyer v. McCormack Real Estate Co., I64 App. Div. (N. Y.)

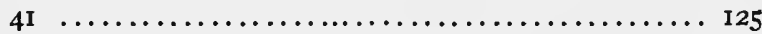

Driscoll v. Independent School District, 6r Iowa $426 \ldots \ldots \ldots 40$

Drumheller v. American Surety Co., 30 Wash. 530........ I 30

Duff v. Hoffmann, $63 \mathrm{~Pa}$. St. 192............... I6r, I74

Dufresne v. Prefontaine, 2I Can. Sup. Ct. $607 \ldots \ldots \ldots \ldots \ldots$....... 43

Dull v. Bramhall, 49 Ill. $364 \ldots \ldots \ldots \ldots \ldots \ldots \ldots \ldots \ldots \ldots$. 60

Duplan Silk Co. v. Spencer, I I5 Federal 689............ I24

Durkin v. City of New York, 49 Misc. (N. Y.) I1 $4 . . . \ldots$ II 4

Durling v. Gould, 83 Me. I34.................. I4I

E.

Eastern, etc., Metal Co. v. Webb Granite, etc., Co., I95 Mass.

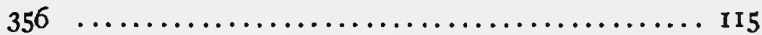

Elliott v. Missouri, etc., Co., 74 Federal $707 \ldots \ldots \ldots \ldots \ldots \ldots$ I2I

Elliston v. Jackson Water Co., I2 Cal. 542............. I4I

Embury v. 42nd St. \& Madison Avenue Co., et al., N. Y. L. J.

April I6th, I9I5..................... 150, I56

Emerson v. Kneezel, 62 S. W. (Tex. Civ. App. Dec. I900) 55142

English v. Warren, 65 N. J. Eq. $30 \ldots \ldots \ldots \ldots \ldots \ldots \ldots \ldots$. $\ldots \ldots$, I77

Entenman v. Anderson, I06 N. Y. A. D. 149........... I45

Ericsson v. Browne, 38 Barb. (N. Y.) $390 \ldots \ldots \ldots \ldots \ldots \ldots$ I49

Erskine v. Johnson, 23 Neb. $265 \ldots \ldots \ldots \ldots \ldots \ldots \ldots \ldots \ldots$

Ex parte Schmidt, 62 Ala. $252 \ldots \ldots \ldots \ldots \ldots \ldots \ldots \ldots$ I4I

F.

Fagan v. Boyle, etc., Co., 65 Texas $324 \ldots \ldots \ldots \ldots \ldots \ldots$......... 67

Farmer v. St. Croix, etc., Co., II7 Wis. $76 \ldots \ldots \ldots \ldots \ldots$ I74 
Farrell v. Levy, 139 (N. Y.) A. D. $790 . \ldots \ldots \ldots \ldots \ldots \ldots$........ II9, 120

Favor v. Philbrick, 7 New Hampshire $326 \ldots \ldots \ldots \ldots \ldots$ in 8

Fay v. Muhlker, I Misc. (N. Y.) $321 \ldots \ldots \ldots \ldots \ldots \ldots \ldots$. 102

Felgenhauer v. Haas, 123 A. D. (N. Y.) $75 \ldots \ldots \ldots \ldots \ldots$. 163

Feltham v. Sharp, 99 Ga. 260,25 S. E. 619.............. 42

Feltus v. Swan, 62 Miss. $415 \ldots \ldots \ldots \ldots \ldots \ldots \ldots \ldots \ldots \ldots$. 69

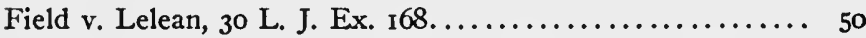

v. Consolidated Water Co., 25 R. I. 319............ I49

Filston Farm Co. v. Henderson (Md. Ct. of App. June 27, 1907) 67 Atl. 228....................... 106

Fireproof Building Co. v. First National Bank, 54 Super.

Court (N. Y.) $511 \ldots \ldots \ldots \ldots \ldots \ldots \ldots \ldots \ldots \ldots \ldots \ldots \ldots \ldots, 23$

First Natl. Bank, etc. v. Trigg Co., 106 Va. $327 \ldots \ldots \ldots \ldots . .143$

Fitzgerald v. Benner, 219 Ill. 485, 76 N. E. $709 \ldots \ldots \ldots \ldots$..... 106

v. Moran et al., I4I N. Y. $419 \ldots \ldots \ldots \ldots \ldots \ldots \ldots$ I7, 22

Fitzhugh v. Mason, 2 Cal. App. 220, 83 Pac. $282 \ldots \ldots \ldots \ldots 6$

Flaherty v. Miner, I23 N. Y. $382 \ldots \ldots \ldots \ldots \ldots \ldots \ldots \ldots$ I02

Flanikin v. Fokes, 15 Texas $180 \ldots \ldots \ldots \ldots \ldots \ldots \ldots \ldots, 4$

Foley v. Algar, 4 E. D. Smith (N. Y.) 7 Ig, I $34 \ldots \ldots \ldots \ldots$ I 45

Fontano v. Robbins, 22 App. Cas. (D. C.) $253 \ldots \ldots \ldots \ldots$...... 18

Foshay v. Robinson, I6 N. Y. Supp. 817, 137 N. Y. 134...171, 172

Fox v. Rogers, I7I Mass. $546 \ldots \ldots \ldots \ldots \ldots \ldots \ldots \ldots$ I 8

v. Powers, 65 (N. Y.) A. D. $112 \ldots \ldots \ldots \ldots \ldots \ldots \ldots$. 123

v. Rucker, $30 \mathrm{Ga} .525 \ldots \ldots \ldots \ldots \ldots \ldots \ldots \ldots \ldots \ldots \ldots \ldots \ldots \ldots$ I 44

Francis v. Heine, etc., Co., I05 Federal 413, I09 Federal 838. . II5

Freedman v. Sandknop, 53 N. J. Eq. 243............. 176

Freeman v. Gilpin, I Phila. $23 \ldots \ldots \ldots \ldots \ldots \ldots \ldots \ldots \ldots$ I42

v. Rinaker, 185 Ill. I72 $\ldots \ldots \ldots \ldots \ldots \ldots \ldots \ldots \ldots$ I 49

Frohlich v. Klein, 160 Mich. $142 \ldots \ldots \ldots \ldots \ldots \ldots \ldots \ldots$ 163

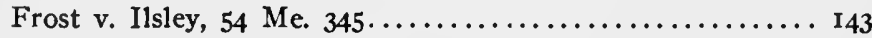

Friedland v. McNeil, 33 Mich. $40 \ldots \ldots \ldots \ldots \ldots \ldots \ldots . . . \ldots$

Friedlander v. Taintor, 14 N. D. (104 N. W. 527) $393 \ldots . .$. I 49

G.

Gardner, etc., Co. v. N. Y. Central, etc., Co., 72 N. J. L. 257. 174 Garrison v. Borio, 6I N. J. Eq. 236, 47 Atl. 1060.........144, 174 Gaskell v. Beard, 58 Hun. (N. Y.) Ior................ 167 General Supply Co. v. Hunn, 126 Ga. 615............. 145 Gibson County v. Matherwell Iron, etc., Co., I23 Ind. $364 \ldots 32$ Gilman v. Stevens, 54 How. Pr. (N. Y. Super. Ct.) $197 \ldots \ldots \ldots \ldots \ldots \ldots \ldots \ldots \ldots, 60,61,75,79,86$

Girard Life Insurance Co. v. Cooper, I62 U. S. $529 \ldots \ldots \ldots$ II 5 Glacius v. Black, 50 N. Y. $145 \ldots \ldots \ldots \ldots \ldots \ldots \ldots$. 24, I64 v. Black, 67 N. Y. $563 \ldots \ldots \ldots \ldots \ldots \ldots \ldots \ldots \ldots \ldots \ldots \ldots$ 


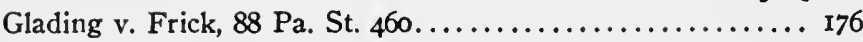

Glaholm v. Hays, 2 M. \& G. $265 \ldots \ldots \ldots \ldots \ldots \ldots \ldots \ldots \ldots$

Gordon v. Torrey, I5 N. J. Eq. I12.............. 168

Graham v. The Commissioner of Works, Builder, Nov. 15,

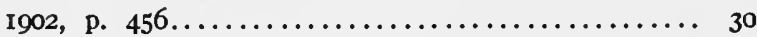

Gray v. La Societe Francaise, etc., I3I California $566 . . \ldots$... I8

Green v. Williams, 92 Tenn $220 \ldots \ldots \ldots \ldots \ldots \ldots \ldots \ldots \ldots \ldots$ I70

v. Brooks, 8r Cal. 328, 22 Pac. Rep. $849 \ldots \ldots \ldots \ldots \ldots \ldots 4$

Grave v. Ganer, 36 Wisconsin $369 \ldots \ldots \ldots \ldots \ldots \ldots \ldots \ldots$ Ir 4

Gurney v. Atlantic, etc., Co., 58 N. Y. $358 \ldots \ldots \ldots \ldots \ldots \ldots$. . . . 49

H.

Haines v. Holland ( 1898 Tenn. Ch. App.) 48 S. W. $400 . \ldots$. I62

Hall v. Wright, 96 E. C. L. $746 \ldots \ldots \ldots \ldots \ldots \ldots \ldots \ldots \ldots . \ldots$

Halsey v. Waukesha Springs Sanitarium Co., I25 Wis, 3Ir,

I04 N. W. $94 \ldots \ldots \ldots \ldots \ldots \ldots \ldots \ldots \ldots \ldots$ I07

Hammond v. Darlington, 84 S. W. (Missouri, 1904) $446 \ldots$. I 40

Handy v. Bliss, 204 Mass. $513 \ldots \ldots \ldots \ldots \ldots \ldots \ldots \ldots$ I $\ldots \ldots \ldots \ldots \ldots \ldots$ I9

Harbeck v. Southwell, I8 Wis. 4 I8............... I74

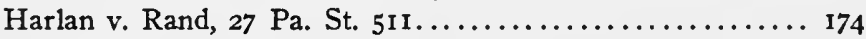

Harmer v. Cornelius, 5 C. B. (N. S.) $236 \ldots \ldots \ldots \ldots \ldots \ldots 67$

Hart v. Globe Iron Works, 37 Ohio St. $75 \ldots \ldots \ldots \ldots \ldots$ I68

Hartley v. Murtha, 5 N. Y. A. D. $408 \ldots \ldots \ldots \ldots \ldots \ldots \ldots$.......... 66

Hatch v. Fansher, i6 R. I. $459 \ldots \ldots \ldots \ldots \ldots \ldots \ldots \ldots$ I70

Havens v. Donahue, 43 Pac. Rep. (Cal. Supreme Court I896)

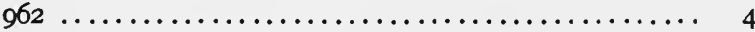

Hayne v. Gray, $125 \mathrm{Cal} .372 \ldots \ldots \ldots \ldots \ldots \ldots \ldots \ldots \ldots$ 10

Hayes v. Wagner, II3 Illinois Appeals 299............. II6

Hazard, etc., Co. v. Loomis, 2 Disney (Ohio) $544 \ldots . . \ldots$. I46

Heamann v. Porter, 35 Mo. I37............... I4I

Hedden Const. Co. v. Proctor, etc., Co., 62 Misc (N. Y.) 129.. I78

v. Rossiter, etc., Co. 136 N. Y. A. D. $601 \ldots \ldots \ldots \ldots .124$

Heidlinger v. Onward Const. Co., 44 Misc. (N. Y.) 555, 90

N. Y. Supp. (I24 N. Y. St. Rep.) II5......... I06

Hemming v. Hale et al., 7 C. B. N. S. (Common Bench, New

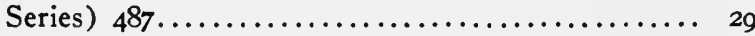

Henry, etc., Co. v. Halter, 58 Neb. $685 \ldots \ldots \ldots \ldots \ldots \ldots$. . . . 49

Hebert v. Dewey, I9I Mass. 403, 77 N. E. $822 \ldots \ldots \ldots \ldots \ldots$. . . 106

Herell v. Donovan, 7 App. Cases (D. C.) $322 \ldots \ldots \ldots \ldots \ldots$ I 45

Herman et. al., v. City of New York, 130 N. Y. A. D. 531... 178

Heroy v. Hendricks, 4 E. D. Smith (N. Y.) $768 \ldots \ldots \ldots \ldots$ I74

Herrick v. Estate of Sewall Belknap et al., 27 Vt. 673...... 13

Hickey v. Schwab, 64 How. Pr. (N. Y.) $8 . \ldots \ldots \ldots \ldots \ldots$ I4I 
Highton v. Dessau, 139 N. Y. 607, 19 N. Y. Sup. $395 \ldots \ldots \ldots$.... 164

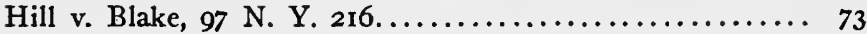
Hinckley v. Fields, etc., Co., 91 Cal. I36.............. I6I Hoff's Appeal, 102 Pa. St. $218 \ldots \ldots \ldots \ldots \ldots \ldots \ldots \ldots$. 68

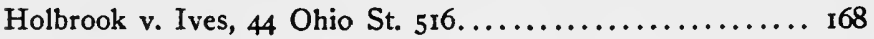
Holding v. Pigott, 7 Bing. $465,474 \ldots \ldots \ldots \ldots \ldots \ldots \ldots \ldots$. 50 Holl v. Long, 34 Misc. (N. Y.) I.................. 164 Homersham v. Wolverhampton Water-works Co., 6 Exch. I37 13 Horgan v. New York, I14 N. Y. A. D. $555 \ldots \ldots \ldots \ldots \ldots \ldots, 42$ Horn, etc., Co. v. Steelman, 215 Pa. St. $187 \ldots \ldots \ldots \ldots \ldots$....... 145 Howard v. Pensacola, etc., Co., 24 Florida $560 . . . \ldots \ldots$... II5, II6 Hubert v. Aitken, 2 N. Y. Supp. 7 II, 5 N. Y. Supp. 839, I5 Daly (N. Y.) 237 , 123 N. Y. $655 \ldots \ldots .76,81,82,86$, 149 Hunter v. Truckee Lodge, etc., I4 Nev. $24 \ldots \ldots \ldots \ldots \ldots$. I7 I Hutchinson v. Tatham, Law Rep. 8 C. P. $482 \ldots \ldots \ldots \ldots$..... 50 Huttig Bros., etc. Co. v. Denny Hotel Co., 6 Wash. 122 $167,170,173$

I.

Iaege v. Bossieux, I5 Grat (Va.) $83 \ldots \ldots \ldots \ldots \ldots \ldots \ldots$ I75 Irving v. Morrison, 27 C. P. (Upper Canada) $242 \ldots \ldots \ldots \ldots 88$ Isaacs v. Dawson, 70 A. D. (N. Y.) 232, I74 N. Y. $537 \ldots \ldots$... 120

$\mathrm{J}$.

Jackson Architectural Iron Works v. Rouss, 39 St. Rep. 359,

I5 N. Y. Supp. 137, I33 N. Y. $538 \ldots \ldots \ldots \ldots \ldots \ldots 27$

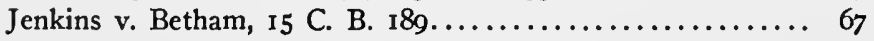

Johnson v. McClure, Io N. M. $506 \ldots \ldots \ldots \ldots \ldots \ldots \ldots$........... I49

v. O'Neill et al., I48 N. W. (Mich. 19I4) $364 \ldots \ldots \ldots \ldots, 55$

v. Wanamaker, $17 \mathrm{~Pa}$. Sup. Ct. $301 \ldots \ldots \ldots \ldots \ldots \ldots \ldots, 75$

Jones v. Brown, 54 Iowa $74 \ldots \ldots \ldots \ldots \ldots \ldots \ldots \ldots . \ldots \ldots$

v. Reg., 7 Can. Sup. Ct. $570 \ldots \ldots \ldots \ldots \ldots \ldots \ldots \ldots$.......... 18

Joplin Supply Co. v. West, 149 Mo. App. $78 \ldots \ldots \ldots \ldots \ldots$ I 43

$\mathrm{K}$.

Kane v. Stone Co., 39 Ohio St. I.................. I63 Kelly v. Bloomingdale, 19 N. Y. Supp. 126, I39 N. Y. $343 \ldots$... 172

v. Fejervary, 78 Northwestern $828 \ldots \ldots \ldots \ldots \ldots \ldots$. 126

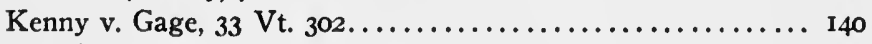

Kerwin v. Post, 120 N. Y. A. D. $179 \ldots \ldots \ldots \ldots \ldots \ldots \ldots$.......... 157

Kilgore v. Northwest Texas Baptist Educational Society, 89

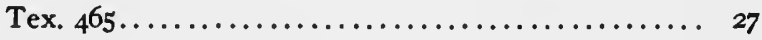

Kimberly v. Dick, L. R. 13 Eq. I.................. I7 
Kirk v. Guardians, etc., 2 Phila. 640, I Redfield Am. R. R. Cases, $305 \ldots \ldots \ldots \ldots \ldots \ldots \ldots \ldots \ldots \ldots \ldots$ I6

Kirschner v. Mahoney, 96 N. Y. Supp. 195 ........... I7 I

Knapp v. Brown, 45 N. Y. $207 \ldots \ldots \ldots \ldots \ldots \ldots \ldots \ldots \ldots . \ldots \ldots$

Knelly v. Horwath, $208 \mathrm{~Pa}$. St. 487,57 Atlantic $957 \ldots \ldots \ldots$.... I44

Knight v. Norris, 13 Minn. $473 \ldots \ldots \ldots \ldots \ldots \ldots \ldots .60,149$

Knowlton v. Ellis, 12 Phil. (Pa.) $396 \ldots \ldots \ldots \ldots \ldots \ldots \ldots$........... 170

Kutts v. Pelby, 20 Pick. (Mass.) $65 \ldots \ldots \ldots \ldots \ldots \ldots \ldots 40,45$

La Foucherie v. Knutzen, 58 N. J. L. $234 \ldots \ldots \ldots \ldots \ldots$. 76

LaGrill v. Mallard, 90 Cal. $373 \ldots \ldots \ldots \ldots \ldots \ldots \ldots \ldots$. 6 I, I62

Laird v. Moonan, 32 Minn. $358 \ldots \ldots \ldots \ldots \ldots \ldots \ldots \ldots$ I43

Lake v. McElfatrick, I39 N. Y. 349, 46 N. Y. St. Rep. 437,

19 N. Y. Supp. $494 \ldots \ldots \ldots \ldots \ldots \ldots \ldots \ldots \ldots \ldots . \ldots \ldots$

Lambert v. Sanford, 55 Conn. $437 \ldots \ldots \ldots \ldots \ldots \ldots \ldots \ldots .59$

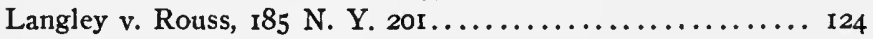

v. Rouss, 85 (N. Y.) A. D. $27 \ldots \ldots \ldots \ldots \ldots \ldots \ldots$. 17

La Pasta v. Weil, 20 Misc. (N. Y.) 554, 20 Misc. (N. Y.) 10. . I7I

Larrimore v. Comanche County (Tex. Civ. Apps. Sep. I895)

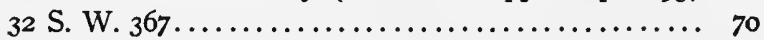

Lavanway v. Cannon, 37 Wash. 593, 79 Pac. $1117 \ldots \ldots \ldots$...... I07

Lee v. Lord Bateman. Times, October 31 , $1893 \ldots \ldots \ldots \ldots$...... 30

Legg v. Dunleavy, 80 Mo. 558, 50 Am. Rep. 512......... 7

Lester v. Houston, Ior North Carolina, 605........... $161-162$

Leverone v. Arancio, 179 Mass. $439 \ldots \ldots \ldots \ldots \ldots \ldots \ldots$. 17

Lewis v. Slack, 27 Mo. App. Irg.............. I8, 25

L'Hommedieu v. Winthrop, 59 A. D. (N. Y.) $192 \ldots \ldots \ldots \ldots 165$

Libbey et al. v. Tidden et al., I92 Mass. 175...........150, 154

Linden Steel Co. v. Rough Run Manufacturing Co., $158 \mathrm{~Pa}$.

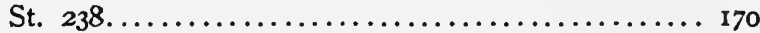

Lippincott v. Yorke, 86 Tex. $276 \ldots \ldots \ldots \ldots \ldots \ldots \ldots \ldots . \ldots \ldots$

Loftus v. Jorjorian, 194 Mass. 165, 80 N. E. $235 \ldots \ldots \ldots \ldots$ I06

Lonford v. Diettrich, 87 Ala. $250 \ldots \ldots \ldots \ldots \ldots \ldots \ldots$ I

Loomis v. Knox, 60 Conn. $343 \ldots \ldots \ldots \ldots \ldots \ldots \ldots$. 440

Lord v. Thomas, 64 N. Y. 107.................. 58

Lottman v. Barnett, 62 Missouri $159 \ldots \ldots \ldots \ldots \ldots 69,75,85$

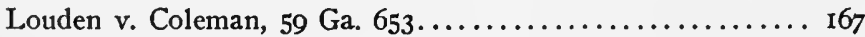

Louisville Foundry Co. v. Patterson (Ky. Ct. of App. May

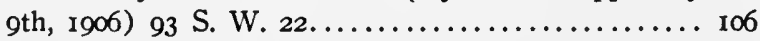

Louisiana Molasses Co. v. Le Sassier et al., 52 La. Ann. 20709 Ludbrook v. Barrett, 46 L. J. C. P. $798 \ldots \ldots \ldots \ldots \ldots \ldots$. $18 \mathrm{r}$ Lunsford v. Dietrich, 86 Ala. $250 \ldots \ldots \ldots \ldots \ldots \ldots \ldots$.......... 82 
Lyle v. Jackson Co., 23 Arkansas $63 \ldots \ldots \ldots \ldots \ldots \ldots \ldots$ I15

M.

Maak v. Schneider, 57 Mo. App. $431 \ldots \ldots \ldots \ldots \ldots \ldots \ldots . \ldots . \ldots 2$

Maas v. Hernandez, 48 La. Ann. 264 , I9 So. $269 . \ldots \ldots \ldots \ldots$.... 40

Macomber v. Bigelow, I26 Cal. $9 . \ldots \ldots \ldots \ldots \ldots \ldots \ldots$ I74

Macondray v. Simmons, I Cal. $393 \ldots \ldots \ldots \ldots \ldots \ldots \ldots$. 142

Mahon v. Guilfoyle, I8 N. Y. Supp. $93 \ldots \ldots \ldots \ldots \ldots \ldots$ I63

Mahoney v. Oxford Realty Co., I33 A. D. (N. Y.) $656 \ldots .$. I24

Majory v. Shubert, 82 (N. Y.) A. D. $633 \ldots \ldots \ldots \ldots \ldots \ldots$ II

Malbon v. Birney, II iWis. I07................... I63

Maldard et al. v. Moody et al., 105 Ga. $400 \ldots \ldots \ldots \ldots \ldots$........ I8

Machester v. Searle, I2I Mass. $418 \ldots \ldots \ldots \ldots \ldots \ldots \ldots \ldots$ I 46

Marcotte v. Beaupre, 15 Minn. 152..............40, 54

Marquis v. Lauretson, (Iowa Sup. Ct. 1888 ), 40 N. W. 73.... 44

Marshall v. Cohen, II Misc. (N. Y.) $397 \ldots \ldots \ldots \ldots \ldots \ldots \ldots$ I 45

Martin v. Oberle, 85 N. Y. Misc. $35 \ldots \ldots \ldots \ldots \ldots \ldots \ldots$ III

Martine v. Nelson, 51 Ill. $422 \ldots \ldots \ldots \ldots \ldots \ldots \ldots \ldots \ldots$ I 42

Marx v. White Co., I43 N. Y. Supp. I036............. I00

May v. Menton, 18 Misc. (N. Y.) $737 \ldots \ldots \ldots \ldots \ldots \ldots \ldots \ldots \ldots$

Mayes v. Reg., 23 Canadian Sup. Ct. 454, 2 Exch. 403....... I8

Mayor v. Cunliff, 2 N. Y. 165....................... 68

McClallan v. Smith, in Cush. (Mass.) 238.............. I75

McCullough v. Moore, III Illinois Appeals $545 \ldots \ldots \ldots \ldots$ I 28

McDonald v. Patterson \& Co., I86 Ill. 38I, 84 IIl. Apps. 326. . I66

McIntosh v. Hastings, 156 Mass. $344 \ldots \ldots \ldots \ldots \ldots \ldots$ I8

McKeon v. Sumner Building, etc., Co., 5I La. Ann. I96I..... I43

McKnight, etc., Co. v. The Mayor, I60 N. Y. 72......... I02

McManus v. Rothschild, 25 Ontario L. R. I38........... I28

McMahon v. N. Y. Co., 20 N. Y. $463 \ldots \ldots \ldots \ldots \ldots \ldots \ldots$ I2I

McNulty v. Offerman, I64 N. Y. A. D. $949 \ldots \ldots \ldots \ldots \ldots \ldots$ I58

McPherson v. Rockwell, 37 Wis. $159 . \ldots \ldots \ldots \ldots \ldots \ldots \ldots 28$

Merchants Insurance Co. v. Mazange, 22 Ala. 168......... I40

Merrigan v. English, 9 Mon. II3................170, 17 I

Merrill-Ruckgaber Co. v. New York, 160 N. Y. A. D. 513 .... I03

Merriman v. Fowler, 37 N. J. L. $89 \ldots \ldots \ldots \ldots \ldots \ldots \ldots \ldots, 75$

Meyers v. Daly, 7 Daly (N. Y.) $471 \ldots \ldots \ldots \ldots \ldots \ldots$.......... I 45

Mills v. Paul, 30 Southwestern $558 \ldots \ldots \ldots \ldots \ldots \ldots \ldots$. 26 , 127

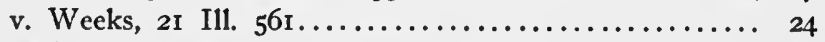

Mitchell v. Dougherty, 86 Federal $859 \ldots \ldots \ldots \ldots \ldots \ldots$ I2I

v. Kavanagh, 38 Iowa $286 \ldots \ldots \ldots \ldots \ldots \ldots \ldots$ I2I

v. Packard, 168 Mass. $467 \ldots \ldots \ldots \ldots \ldots \ldots \ldots \ldots$. 153

Modern Steel Structure Co. v. English Const. Co., I29 Wis.

$31,108 \mathrm{~N}$. W. $70 . \ldots \ldots \ldots \ldots \ldots \ldots \ldots \ldots \ldots$. 107 
Moffatt v. Scott, 8 L. C. Jur. 310..................... 90

Mohawk, etc., Co. v. Brown et. al., I63 N. Y. A. D. 157

Moneypenny v. Hartland, I C. \& P. (Carrington \& Payne)

352, 2 C. \& P. 378.................42, 53, 86

Montandon v. Deas, I4 Ala. 33................ 146

Moon v. Guardians of the Poor, 3 Bingham's N. Cas., 814 ... 3I

Moore v. Dugan, 179 Mass. $153 \ldots \ldots \ldots \ldots \ldots \ldots \ldots \ldots \ldots$

Mornan v. Carroll, 35 Iowa $22 \ldots \ldots \ldots \ldots \ldots \ldots \ldots \ldots \ldots \ldots$

Morrison v. Universal, etc., Co., L. R. 8 Exch. Cases $197 . .$. . 108

v. Whaley, I6 R. I. $715 \ldots \ldots \ldots \ldots \ldots \ldots \ldots \ldots \ldots \ldots \ldots \ldots$

Morrison Co. v. Williams, 200 Mass. $406 \ldots \ldots \ldots \ldots \ldots \ldots$ I63

Morse v. Maurer, $35 \mathrm{~Pa}$. Super. Ct. Ig6.............. I I 5

Mosher v. Lewis, 1o N. Y. Misc. $373 \ldots \ldots \ldots \ldots \ldots \ldots \ldots 155$

Muldoon v. Pitt, 54 N. Y. $269 \ldots \ldots \ldots \ldots \ldots \ldots \ldots \ldots . \ldots \ldots, 146$

Mulligan v. Mulligan, 18 La. Ann. 21.............60, 149

Mutual Benefit, etc. Co. v. Rowand, 26 N. J. Eq. 389, I2 C. E.

Green (N. J.) $604 \ldots \ldots \ldots \ldots \ldots \ldots \ldots \ldots \ldots \ldots . \ldots 149$

N.

National Contracting Co. v. Hudson, etc. Power Co., 67 A. D.

(N. Y.) 620,170 N. Y. $439 \ldots \ldots \ldots \ldots \ldots \ldots \ldots$ I3I

National Wall-Paper Co. v. Sire, 163 N. Y. $122 \ldots \ldots \ldots \ldots 158$

Nellis v. Bellinger, 6 Hun. N. Y. $560 \ldots \ldots \ldots \ldots \ldots \ldots \ldots \ldots 159$

Nelson v. Spooner, 2 F. \& F. 6rз ..............40, 42

Nesbit v. Braker, I04 N. Y. A. D. $393 \ldots \ldots \ldots \ldots \ldots$ I63, I64, I65

Newman v. Fowler, 37 N. J. L. 89...............77, 107

Newark Lime, etc., Co. v. Morrison, I3 N. J. Eq. 133..... 143

N. J. Steele, etc., Co. v. Robinson, 33 Misc. (N. Y.) 36I ..... I7I

N. Y. \& N. H. Automatic Sprinkler Co. v. Andrews, I73 N.

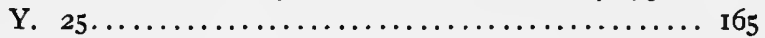

N. Y. Building Co. v. Springfield, etc., Co., 56 A. D. (N. Y.)

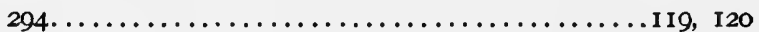

N. Y., etc., Terra Cotta Co. v. Williams, 102 N. Y. A. D. I. . 167

N. Y. State, etc., Bank v. Whitehall Water, etc., Co., I6I N.

Y. A. D. 304.......................... 10r

Niver v. Nash, 35 Pac. Rep. (Wash. Sup. Ct. Dec. I893) 38069

Nolte v. His Creditors, 6 Mart. (N. S.) La. I68........... I75

Norrington v. Wright, I 5 U. S. I88.............. 73

Norris v. Day, ro L. J. N. S. Exch. in Eq. $43 \ldots \ldots \ldots \ldots \ldots 7$

Noyes v. Burton, 29 Barb. N. Y. 631................. 168

O.

Oberlies v. Bullinger, 75 Hun. (N. Y.) $248 \ldots \ldots \ldots \ldots \ldots \ldots 122$ 
O'Brien v. Reg., 4 Can. Supreme Court $529 . \ldots \ldots \ldots \ldots \ldots$ II

O'Keefe v. St. Francis' Church, 59 Conn. 551.......II3, I23, I24 Oldershaw v. Garner, 38 V. C. Q. B. $37 \ldots \ldots \ldots \ldots \ldots \ldots$ I2I Olsen v. Schwarzwelder, Iog N. Y. A. D. 282, 95 N. Y. Supp. 651 .................................. 106

Orlandi et al. v. Gray et al., I25 Cal. $372 \ldots \ldots \ldots \ldots \ldots \ldots$.......

Otis v. Dodd, 90 N. Y. $336 \ldots \ldots \ldots \ldots \ldots \ldots \ldots \ldots \ldots \ldots \ldots \ldots$

Otis Elevator Co. v. Dusenbury, 47 Misc. (N. Y.) $450 . . . \ldots$... 164

P.

Pacific Mutual, etc., Co. v. Fisher, I06 Cal. 224.......... I6I Paladino Contracting Co. v. Walsh et al., I44 N. Y. Supp. 7. . II2 Palmer v. DeWitt, 47 N. Y. $532 \ldots \ldots \ldots \ldots \ldots \ldots \ldots \ldots$ 9I Pappa v. Rose, L. R. 7 C. P. 32, 525, I Eng. Rep. 87, 2 Eng.

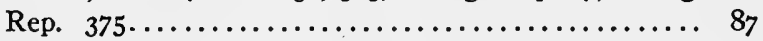

Parker v. Anthony, 4 Gray (Mass.) $289 \ldots \ldots \ldots \ldots \ldots \ldots$......... 146

Pashby v. Mayor, etc. of Birmingham, 86 E. C. L. 2........ I2I

Pell v. Baur, I33 N. Y. $377 \ldots \ldots \ldots \ldots \ldots \ldots \ldots \ldots \ldots \ldots$. 158

Pendleburg v. Meade, I E. D. Smith N. Y. $728 \ldots \ldots \ldots \ldots$...... I70

Pennock v. Hooper, 5 Rawle (Pa.) $290 . . . \ldots \ldots \ldots \ldots \ldots$. I68

People v. Campbell, 82 N. Y. $247 \ldots \ldots \ldots \ldots \ldots \ldots \ldots \ldots . . . \ldots 4$

People ex rel. Rapid Transit, etc. Co. v. Craven, 210 N. Y.

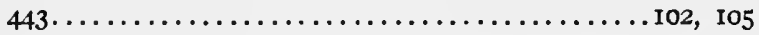

Pere Marquette R. Co. v. Baertz, 36 Ind. Apps. 408........ I74

Perry v. Levenson, 82 N. Y. A. D. 94 , I78 N. Y. $559 \ldots \ldots \ldots .27$

v. Potashinski, I69 Mass. 35ז..........145, I68, I70, I73

Person v. Stoll, 72 N. Y. A. D. I4I, I74 N. Y. $548 \ldots \ldots \ldots$ I73

Petersen v. Rawson, 34 N. Y. 370, 2 Boswell, N. Y. 234

$\ldots \ldots \ldots \ldots \ldots \ldots \ldots \ldots \ldots \ldots \ldots \ldots \ldots \ldots \ldots \ldots \ldots, 77,84$

Phoenix Furniture, etc., Co. v. Put-In Bay Hotel Co., 66 Fed.

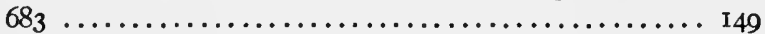

Pierce v. Thurston, 40 App. Div. (N. Y.) $577 \ldots \ldots \ldots \ldots 40,56$

Pleasant College v. Colett, I42 Kentucky $342 \ldots \ldots \ldots \ldots \ldots$ I 22

Poitras v. Deslauriers, 4 Rev. Leg. $375 \ldots \ldots \ldots \ldots \ldots \ldots$........

Powell v. Nolan, 27 Washington $318 \ldots \ldots \ldots \ldots \ldots \ldots \ldots$ I62

Pratt v. Tudor, 14 Tex. $37 \ldots \ldots \ldots \ldots \ldots \ldots \ldots \ldots \ldots \ldots$ i 40

Prince v. Neal Millard Co., I24 Ga. 892.............. I43, I7I

Pritzlaff, etc. Co. v. Berghoefer, I03 Wis. $359 \ldots \ldots \ldots \ldots \ldots$....... 163

R.

Raeder v. Pensberg, 6 Mo. App. 445................ 149

Rafter v. Sullivan, I3 Abbts. Pr. (N. Y.) $262 \ldots \ldots \ldots \ldots$ I4I

Randell et al. v. Trimen, I8 C. B. (Common Bench) $786 \ldots .33$ 
xxxiv

Reg. v. Stars et al., Can. Sup. Ct. II8............... I8

Renton v. Monniere, 77 Cal. $449 \ldots \ldots \ldots \ldots \ldots \ldots \ldots \ldots \ldots . \ldots \ldots$

Resher v. Freres des Ecoles Chretiennes, 34 L. C. Jur. 89. ... 45

Rex. v. Peto, I Young \& Jarvis $37 \ldots \ldots \ldots \ldots \ldots \ldots \ldots$ i 8

Richard v. Clark, 43 Misc. (N. Y.) $622 \ldots \ldots \ldots \ldots \ldots \ldots 17,27$

Richardson v. Hickman, 32 Ark. $406 \ldots \ldots \ldots \ldots \ldots \ldots \ldots$

Rinn v. Electrical Power Co., 3 N. Y. A. D. 305 .... I48, I50, I5I

Ripley v. U. S., 223 U. S. $695 \ldots \ldots \ldots \ldots \ldots \ldots \ldots \ldots \ldots$ II9, I 20

Robinson v. Springfield Iron Co., $39 \operatorname{Hun}(N$. Y.) $634 \ldots \ldots$. . 31

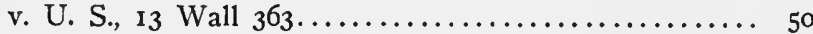

Rochford v. Rochford, I92 Mass. 231.............. I63

Robins v. Goddard (I905) I K. B. 294................ I07

v. Bunn, 34 N. J. L. $322 \ldots \ldots \ldots \ldots \ldots \ldots \ldots \ldots \ldots$ I6

Roebling's Sons' Co. v. Humboldt, etc., Co., II2 Cal. 288. ... I6 I

Rowley v. Bigelow, I2 Pick. (Mass.) $307 \ldots \ldots \ldots \ldots \ldots \ldots$........ 108

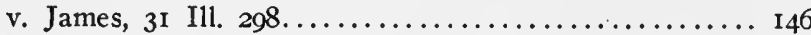

Ruigle v. Wallis Iron Works, I49 N. Y. $439 \ldots \ldots \ldots \ldots \ldots \ldots$. . 63

Rush v. Able, go Pa. St. I53................... I45

\section{$\mathrm{S}$.}

Salem v. Lane, etc., Co. I89 Ill. $593 \ldots \ldots \ldots \ldots \ldots \ldots \ldots$ I6I

Savannah, etc., R. Co. v. Grant, 56 Ga. $68 \ldots \ldots \ldots \ldots \ldots$ I4I

Sawyer v. Schick, 30 Okla. $353 \ldots \ldots \ldots \ldots \ldots \ldots \ldots \ldots \ldots$ I40

Schenck v. Uber, 8I Pa. St. 31................. I6r

Schillinger Fireproof Cement, etc., Co. v. Arnott, 86 Hun. N.

Y. 182,152 N. Y. $584 \ldots \ldots \ldots \ldots \ldots \ldots \ldots \ldots \ldots \ldots \ldots \ldots$

Schliess v. Grand Rapids, I3I Michigan 52......... I21, I22

Schmulbach v. Caldwell et al., 215 Fed. Rep. 70......... IO2

Schreiner v. Miller 67 Iowa $91 . \ldots \ldots \ldots \ldots \ldots \ldots \ldots \ldots 6,74$

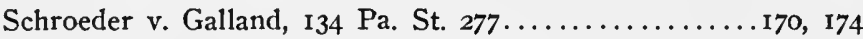

Scott v. Christ's Church Cathedral, I L. C. L. J. $63 \ldots \ldots \ldots .77$

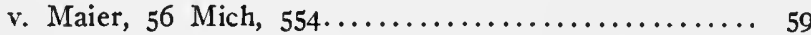

Seaman v. Biemann, I08 Wis. $365 \ldots \ldots \ldots \ldots \ldots \ldots \ldots \ldots$ I70, 174

Sharpe v. San Paulo, etc. Co. 27 L. T. Rep. N. S. 699, L. R.

8 Ch. App. 605 (Notes) L. R. 8 Ch. App. $597 \ldots \ldots$.... I 8

Shaw v. Andrews, 9 Cal. $73 \ldots \ldots \ldots \ldots \ldots \ldots \ldots$ 10

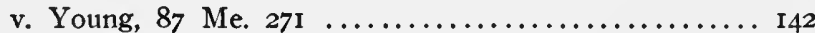

Sherry v. Madler, I23 Wis. $621 \ldots \ldots \ldots \ldots \ldots \ldots \ldots \ldots \ldots \ldots 6_{3}$

Shipman v. State, 43 Wis. $381 \ldots \ldots \ldots \ldots \ldots \ldots \ldots, 79$

Shurman v. George Backer, etc., I44 N. Y. Supp. 9....... I02

Simpson v. Dalrymple, I I Cushing (Mass.) $308 \ldots \ldots \ldots \ldots \ldots$ I45

Sinclair v. Tallmadge, 35 Barb. (N. Y.) $602 \ldots \ldots \ldots \ldots \ldots$. . . 63

Slack v. Collins, 145 Ind. $569 \ldots \ldots \ldots \ldots \ldots \ldots \ldots \ldots \ldots$ 14r 
Small v. Burke, 92 A. D. (N. Y.) $338 \ldots \ldots \ldots \ldots \ldots \ldots$. 127

Smith v. Bradbury, 148 Cal. 4r................... I75

Smith v. Bruyere, I52 S. W. (Tex. 1913) 813 ........... 55

v. Coe, 2 Hilt (N. Y.) 365,29 N. Y. $666 \ldots \ldots \ldots \ldots \ldots$....... 163

v. Dickey, 74 Tex. 6I, II S. W. I049.............40, 42

v. Luning, III Cal. $308 \ldots \ldots \ldots \ldots \ldots \ldots \ldots \ldots \ldots$ II

v. Molleson, 148 N. Y. $24 \mathrm{I} \ldots \ldots \ldots \ldots \ldots \ldots \ldots \ldots . \ldots 28$

v. Neubaur, I44 Ind. $95 \ldots \ldots \ldots \ldots \ldots \ldots \ldots \ldots \ldots$ I74

v. Ruggiero, 52 A. D. (N. Y.) $382 \ldots \ldots \ldots \ldots \ldots \ldots \ldots$. 163

Smith et al. v. Farmers Trust Co., 97 Iowa I 17........... I8

Smithmeyer v. U. S., 25 Ct. Cl. 48 I, I47 U. S. $342 \ldots \ldots \ldots 40$, 6r

Snyder v. N. Y. Central, etc., 72 N. J. L. $262 \ldots \ldots \ldots \ldots \ldots$...... I74

Sontag v. Brennan, 75 Ill. $279 \ldots \ldots \ldots \ldots \ldots \ldots \ldots \ldots$ I6 68

Spannhake v. Mountain Construction Co. et al., I59 A. D.

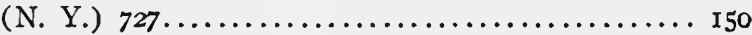

Spurgeon v. MacElwain, 6 Ohio $442 \ldots \ldots \ldots \ldots \ldots \ldots \ldots$ II 5

Starkweather v. Goodman, 48 Conn. IOI.........17, I8, 20, 24

Steger v. Arctic Ref rigerating Co., 89 Tenn. 453.......... I68

Stephens v. Essex County Park Commission (C. C. A.) I43

Fed. $844 \ldots \ldots \ldots \ldots \ldots \ldots \ldots \ldots \ldots \ldots \ldots$. 106

v. United R. R., etc., Co. 29 Ohio St. $227 \ldots \ldots \ldots \ldots$..... 174

Stewart v. Boehme, 53 Ill. App. Court $463 \ldots \ldots \ldots \ldots \ldots \ldots, 76$

Stowell v. Simmons, I Cal. $452 \ldots \ldots \ldots \ldots \ldots \ldots \ldots \ldots \ldots$ I42

Straus v. Buchman et al., 96 N. Y. App. Div. $270 \ldots . .75,78,86$

Stryker v. Cassidy, 76 N. Y. 50, Io Hun. (N. Y.) I8. .148, I49, I50 Stuart v. City of Cambridge, I25 Mass. I02......18, 21, 24, 32 Stubbs v. Hollywell R. Co., L. R. 2 Exch. 311........89, 90 Sundstrom v. The State, 213 N. Y. 68,158 N. Y. A. D. 241 ... I00 Swasey v. Granite, etc. Co., 158 N. Y. A. D. $549 \ldots \ldots \ldots \ldots$...... 150 Sweet v. James, 2 R. I. $270 \ldots \ldots \ldots \ldots \ldots \ldots \ldots \ldots$............... I42 v. Morrison, I I6 N. Y. I9..................119, I32

T.

Tahrland v. Rodier, 16 L. C. Rep. $473 \ldots \ldots \ldots \ldots \ldots \ldots \ldots, 7$

Tayloe v. Sandiford, 7 Wheat (U. S.) 13............ I28

Taylor v. Gilsdorff, 74 Ill. $354 \ldots \ldots \ldots \ldots \ldots \ldots \ldots \ldots$. I 49

Tennis Bros. Co. v. Wetzel, etc., R. Co., I40 Fed. 193..... 142

Tenth National Bank of Philadelphia v. Smith Construction

Co., 2I8 Pa. St. 58I, 67 Atlantic $872 \ldots \ldots \ldots \ldots \ldots$ I44

Thayer v. Vermont Central Railroad Co., 24 Vt. 440........ I3

The Fireproof Building Co. v. The First National Bank, et al.,

54 N. Y. Super. Court $511 . . \ldots \ldots \ldots \ldots \ldots \ldots \ldots .23$

The National Contracting Co. v. Hudson River Water Power

Co., 192 N. Y. $209 \ldots \ldots \ldots \ldots \ldots \ldots \ldots \ldots \ldots, 26$ 
xxxvi

The President, etc., of the Delaware \& Hudson Canal Co. et

al., v. Penn Coal Co., 50 N. Y. 250............ I32

Thomas v. Fleury, 26 N. Y. $26 \ldots \ldots \ldots \ldots \ldots \ldots \ldots \ldots \ldots$. . . . . .

v. Stewart, I32 N. Y. $580 \ldots \ldots \ldots \ldots \ldots \ldots \ldots \ldots \ldots$. 102

Thomson-Starrett Co. v. Brooklyn Hts. Realty Co., I I I N. Y.

A. D. $358 \ldots \ldots \ldots \ldots \ldots \ldots \ldots \ldots \ldots \ldots \ldots \ldots \ldots \ldots \ldots \ldots \ldots \ldots \ldots$

Throckmorton v. Shelton, 68 Conn. $413 \ldots \ldots \ldots \ldots \ldots \ldots$. 440

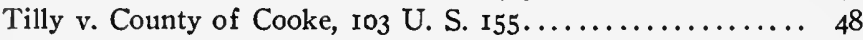

Tobias v. Liesberger, I05 N. Y. 404................ 73

Tommasi v. Archibald, II4 N. Y. A. D. $838 \ldots \ldots \ldots \ldots \ldots \ldots$ I40

Tompkins Co. v. Monticello, etc., Co., I37 Fed. 625.... I63, I64

Traitel v. Oussani, 5I Misc. (N. Y.) 667, I35 N. Y. St. Rep.

(IOI N. Y. Supp.) I05.................... I06

Traitel Marble Co. v. Brown Bros. Inc., I59 N. Y. A. D. 485 . . IOI

Tri-Borough, etc., Co. v. Wechsler Realty Co., I63 N. Y. A. D.

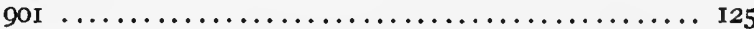

Trueman v. Loder, II A. and E. $589 \ldots \ldots \ldots \ldots \ldots \ldots \ldots$. 50

Trust Co. v. Guigues, 76 N. J. Eq. $495 \ldots \ldots \ldots \ldots \ldots \ldots \ldots$. . . . 63

Tubridy v. Wright, I44 N. Y. 5I9, 7 Misc. N. Y. 403....... I68

Turnes v. Brenckle, 249 Ill. 394.................... I4I

Turney v. Bridgeport, 55 Conn. 4 I $2 \ldots \ldots \ldots \ldots \ldots \ldots \ldots$ II 5

U.

United States v. Buchanan, 8 How. $83 \ldots \ldots \ldots \ldots \ldots \ldots \ldots$ II

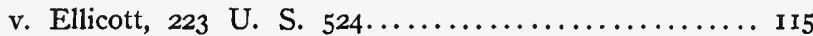

United States Blowpipe Co. v. Spencer, 40 W. Va. 698. ..... I43

Updike v. Skillman, 27 N. J. L. I3I................ I55

Uvalde, etc., Paving Co. v. Central, etc., Co., 84 N. J. L. 297 . . 102

V.

Vail v. Meyer, $7 \mathbf{r}$ Ind. $159 \ldots \ldots \ldots \ldots \ldots \ldots \ldots \ldots \ldots \ldots \ldots$

Vandenberg v. P. T. Walton, etc., Co., I9 Okla. I69....... I74

Vanderhoof v. Shell, 42 Oregon $578 \ldots \ldots \ldots \ldots \ldots \ldots \ldots 27$

Vanderwerker et al. v. Vermont Central Railroad Co., 27 Vt.

I25; Id. I30...................... I3

Van Stone v. Stillwell, etc., Manfg. Co., I42 U. S. I28. I40, I4I, I43

Vaughan v. Ford, I62 Mich. $37 \ldots \ldots \ldots \ldots \ldots \ldots \ldots \ldots$ I70

Vigeant v. Scully, 20 Ill. App. Court $437 \ldots \ldots \ldots \ldots \ldots 7,86,88$

Vogel v. Luitwieler, 52 Hun. (N. Y.) I84............. I74

Von Dorn v. Mengedoht, 4I Neb. 5.25............... I49

W.

Wharton et al. v. Real Estate Inv. Co. et al., I $80 \mathrm{~Pa}$. St. I68 36 Atlantic $725 \ldots \ldots \ldots \ldots \ldots \ldots \ldots \ldots \ldots \ldots \ldots \ldots \ldots \ldots$ 
White v. Abbott, I88 Mass. 99, 74 N. E. 305........... 106, I22

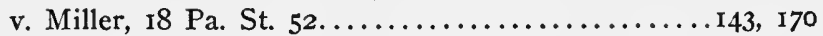

v. San Rafael and San Quentin R. R. Co., 50 Cal. 417..16, I24 Whitla v. Taylor, 6 La. Ann. $480 \ldots \ldots \ldots \ldots \ldots \ldots \ldots \ldots$........... 175 Whittier v. Wilbur, $48 \mathrm{Cal}$. $175 \ldots \ldots \ldots \ldots \ldots \ldots \ldots \ldots \ldots \ldots \ldots \ldots \ldots$ Wigton's Appeal, $28 \mathrm{~Pa}$. St. $161 \ldots \ldots \ldots \ldots \ldots \ldots \ldots \ldots \ldots \ldots \ldots \ldots$ Wilcox v. Stephenson, 30 Fla. $377 \ldots \ldots \ldots \ldots \ldots \ldots \ldots$ I2I Wilcox Manufacturing Co. v. Brazos, 74 Conn. 208......... II7 Wilemet Steam, etc., Co. v. Los Angeles College Co., 94 Cal.

$239 \ldots \ldots \ldots \ldots \ldots \ldots \ldots \ldots \ldots \ldots \ldots \ldots \ldots \ldots$ II 6

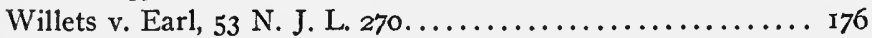

Willey v. Tapping, I $46 \mathrm{~Pa}$. St. $427 \ldots \ldots \ldots \ldots \ldots \ldots \ldots \ldots \ldots$

Wills et al. v. Abbey et al., 27 Texas $202 \ldots \ldots \ldots \ldots \ldots \ldots \ldots$. 4

Winder v. Caldwell, i4 How. U. S. $434 \ldots \ldots \ldots \ldots \ldots \ldots$........ I62

Windrim v. Philadelphia, 9 Philadelphia, Pa. $550 . \ldots \ldots \ldots .90$

Withdrow L. Co. v. Glasgow, etc., Co., Ior Fed. 863....... I4I, I43

Wolf v. Pa. R. Co., 29 Pa. Superior Court $439 \ldots \ldots \ldots \ldots$...... I43

Wollreich v. Fettretch, 4 N. Y. Supp. $326 \ldots \ldots \ldots \ldots \ldots \ldots$ I6 4

Womble v. Hickson, 91 Arkansas $266 \ldots \ldots \ldots \ldots \ldots \ldots \ldots$ II6

Wood v. Donaldson, I7 Wend. (N. Y.) 550, 22 Wend. 395 .... I74

Woodruff v. Rochester \& Pittsburgh R. R. Co., I08 N. Y.

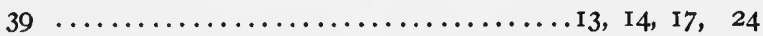

Wagner Co. v. Cawker, II2 Wis. $532 \ldots \ldots \ldots \ldots \ldots$. 8 , 24, 28

Wahle, etc., Co. v. 59th St. \& Madison Ave. Co., I53 N. Y.

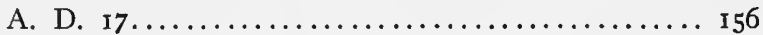

Wahlstrom v. Trulson, I65 Mass. $429 \ldots \ldots \ldots \ldots \ldots \ldots \ldots . \ldots \ldots$

Walbank v. Protestant Hospital, 7 Montreal Q. B. I66..... 46

Walsh v. St. Louis Exposition, etc., Assn., I6 Mo. App. 502, 90

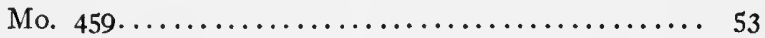

v. St. Louis, etc., Assn, ror Mo. $534 \ldots \ldots \ldots \ldots \ldots \ldots 4^{2}$

Wambald et al. v. Gehring, rog Wis. 122.............. 28

Wandelt v. Cohen, I5 Misc. (N. Y.) $90 \ldots \ldots \ldots \ldots \ldots \ldots \ldots, 45$

Wandenberg v. P. T. Walton, etc., Co., ig Okla. 169....... I74

Ward v. Hudson River, etc., Co., 125 N. Y. 230.....127, 128, 129

v. Yarnelle, I73 Ind. $535 \ldots \ldots \ldots \ldots \ldots \ldots \ldots \ldots$ I4I

Watts v. Metcalf, 23 Ky. L. Rep. 2189, 66 S. W. Rep. 824.... I8

Waugh v. Morris, L. R., 8 Q. B. $202 \ldots \ldots \ldots \ldots \ldots \ldots \ldots$ II 8

Weatherhogg v. Board of Commissioners of Jasper County,

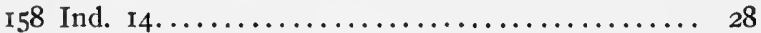

Weaver v. At1., etc. Co., 57 N. J. Eq. $547 \ldots \ldots \ldots \ldots \ldots$....... I777

Webster City, etc., Co., v. Chamberlin, I37 Iowa 717....... I45

Weeks v. O’Brien, I4I N. Y. I99.................. I02, I65

v. The Rector, etc., of Trinity Church, 56 (N. Y.) A.

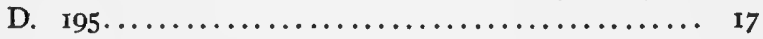


Weggner v. Greenstine, II4 Mich. $310 . . . \ldots \ldots \ldots \ldots \ldots \ldots$ I3

Wendt v. Martin, 89 Ill. $139 \ldots \ldots \ldots \ldots \ldots \ldots \ldots \ldots$.................. 145

Woolf v. Schaefer, I03 N. Y. A. D. 567, 4I Misc. N. Y.

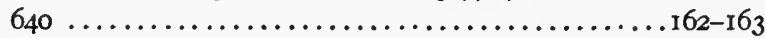

Wright v. Eisle, 86 N. Y. A. D. $356 \ldots \ldots \ldots \ldots \ldots \ldots 90$, 9I

v. Meyer (Tex Civ. App. 1894) 25 S. W. Rep II22...... 28

v. Pohls, 83 Wis. $560 \ldots \ldots \ldots \ldots \ldots \ldots \ldots \ldots$. 171

Wyman v. Hooker, 2 Cal. App. 36, 83 Pac. 79........... 106

Wymard v. Deeds, 21 Pa. Super. Ct. $332 \ldots \ldots \ldots \ldots \ldots \ldots . \ldots 28$

Y.

Yeats v. Pim, Holt N. P. $95 \ldots \ldots \ldots \ldots \ldots \ldots \ldots \ldots \ldots$ jo 


\section{PART I}

THE ARCHITECT AND THE OWNER 



\section{CHAPTER I}

\section{THE RELATIONSHIP IN GENERAL}

$\S$ I. Similar to Other Professional Relationships.-The relationship existing between the architect and the owner, his client, is, to a marked degree, similar and in many respects substantially identical with the relationship existing between an attorney and his client and a physician and his patient. ${ }^{1}$ In each case the professional man is in a position of trust and confidence. In each he is the recognized agent of his client. In each he is assumed to possess, by virtue of the very nature of his calling, a special degree of skill and ability therein; and in each, though as to this infinitely more in the case of the attorney or physician than in the case of the architect, he is under certain obligations to the public and to the State.

$\S 2$. Exceptions to Rule.-Unlike the attorney, the architect, if under examination in court, may not, it seems, successfully plead privilege as to communications between him and his employer ${ }^{2}$ nor yet, it has been held, does he render himself liable in damages by making disclosures of his employer's intention to build or the location of the proposed building, ${ }^{3}$ provided of course that he

${ }^{1}$ Coombs v. Beede, 89 Me. ${ }^{2}$ Wait, Eng. \& Arch. Juris., 187. 772. 
has neither agreed to keep silent as to these matters nor been requested by his employer to treat them as confidential. The rule allowing the architect to make disclosures of this character, without the incurring of liability, is not, however, sufficiently well established to be considered a safe one to act upon, entirely aside from the ethical questions involved; and a case ${ }^{4}$ which has been cited $^{5}$ in support of the rule allowing disclosure by an architect or engineer of the building site selected by the employer does not seem to warrant its citation in this connection, for the reason that the decision is specifically stated to be applicable to situations where no relations of trust or public confidence exist. So far, certainly, as public officers are concerned, such disclosures have not been viewed with favor. ${ }^{6}$

Irrespective of whether his services be gratuitous or not, ${ }^{7}$ the rule holds good that the architect must, subject only to the certain possible exceptions, such as the exception relating to privileged communications just noted, and necessarily occasioned by the peculiar attributes and customs of each profession, preserve toward his client in all their dealings, the same general attitude as that which characterizes the relationships of physician and patient, and attorney and client.

8 Havens v. Donahue, 43 'Pac. Rep. (Cal. Supreme Court 1896) 962.

4 Green v. Brooks, 8I Cal. 328, 22 Pac. Rep. 849.

- Wait, Eng. \& Arch. Juris., p. 772 .
- Wills et al. v. Abbey et al., 27 Texas 202; and see Flanikin v. Fokes, I5 Texas I80; DeLeon v. White, 9 Texas 598.

7 People v. Campbell, 82 N. Y. 247 . 
$\S$ 3. Absolute Good Faith Required.-It is fundamental that the architect must act for his client in absolute and entire good faith throughout, and in all ways consistently with the trust and confidence which the client has reposed in him. ${ }^{8}$

With the contractor, the relationship of the architect, as will be seen, is different, but here too he is under the necessity of acting in perfect sincerity and good faith, although under none of those special obligations which flow from his relation to his client and from the direct contract between them. To the public also, as in the proper supervision of the construction of public or office or tenement or apartment buildings to be occupied or used by the public, he is under obligations to use all reasonable care and diligence, although, publicly, his obligations and duties are naturally less than those of a physician on whom the public health may depend or of an attorney, who is an officer of the court before which he practices. The public obligations of the architect are, however, being recognized more generally of late in the United States as is evidenced by decisions recognizing his accountability to third parties, under circumstances which will be noted, and by legislation in various States regulating the requirements for admission of architects to practice and requiring the obtaining of State certificates before practice may be commenced. ${ }^{9}$

${ }^{8}$ Lewis v. Slack, 27 Mo. Ap. 119; Badger v. Kerber, 6I Ill. 328; Clark on Architects, p. 94 ; Wait on Architectural and
Engineering Jurisprudence, p. $446-7$.

${ }^{\circ}$ Cp. Chap. 454, Laws of 19r5, New York, amending Chap. 25, 
§ 4. Architect to Have No Concealed or Conflicting Interest in Contract.-Inasmuch as the position of the architect is one of trust and confidence, it is clear that he must not, certainly not without the consent of the owner, have the slightest pecuniary interest in the contract or in its performance, other than his interest under his agreement with his employer, or private agreements or understandings of any character whatsoever, relative to the contract or the work in hand, with the contractor or with subcontractors or employees. Such agreements or understandings at once disqualify the architect from acting in that entirely disinterested and single-minded manner, which his position of trust and confidence requires. By entering into any such private agreement or understanding, or by securing any pecuniary interest in the contract other than his interest under his agreement with his employer, the architect exposes himself at once to the danger of dismissal by his client; for it is a well recognized legal principle that an architect who has any pecuniary interest in a contract or its performance other than his interest in the agreed compensation which he is to receive, or, in the absence of express agreement regarding compensation, his interest in such reasonable compensation as he may be entitled to, or an architect who has accepted commissions in connection with the contract from the

New York Laws 1909; N. California, Stat. I9or, p. 64r, J. P. L. 1902, p. 54; vol. I, N. and see, Fitzhugh v. Mason, 2 J. Compiled Stat. pp. IIO-II3, Cal. App. 220, 83 Pac. 282. 
contractor, has so acted as to make it impossible for him to continue properly to represent his employer, and that the latter will be justified in terminating the employment forthwith accordingly. ${ }^{10}$

Where the superintendent of a building whose duties required that he pass upon accounts for materials furnished, made an agreement with a lumber dealer, by the terms of which the latter was required to pay the superintendent a commission on all sales of lumber made as a result of the exercise of his influence with those by whom he was employed, the court held the agreement to be void as against public policy, and this although it appeared that it was not the duty of the superintendent to pass upon accounts for materials furnished to his employers. ${ }^{11}$ The same court in a shortly subsequent decision decided that a writing charging a supervising architect with having given work upon a building, in connection with which he was employed, to certain persons who paid him a commission therefor, was not actionable per se, ${ }^{12}$ which is to say that it did not in itself charge the architect with any criminal or disgraceful conduct, or hold him up to public contempt, scorn, ridicule, or obloquy, or tend to injure him in his profession. While opinions may, perhaps, properly differ as to whether such a state-

10 Norris v. Day, to L. J. lish Encyclopedia of Law, N. S., Exch. in Eq., 43; Tahrland v. Rodier, 16 L. C. Rep. 473; Lloyds Law of Building and Buildings, second edition, §II; American and Eng-

2d. ed., vol. 2, pp. 8I5-8i6.

${ }^{11}$ Atlee v. Fink, 75 Mo. 100, 42 Am. Rep. 385.

12 Legg v. Dunleavy, 80 Mo. 558, 50 Am. Rep. 512. 
ment is libelous or not-and there are those who believe that in our American regard for free speech and a free press, we have not always accorded sufficient protection to the individual, against slander and against libel-these two cases well illustrate the importance in which the courts hold the trust obligations, if we may so term them, of the architect: in that, even where it does not appear that any damage has been occasioned the owner by the acceptance of a commission by the superintendent, nor yet that the mere acceptance of the commission is in itself to be taken as an improper act morally on the part of the superintendent, yet the requirement that one in the latter's position shall be free to carry out his duties without being influenced consciously or unconsciously by conflicting interests, is so insistent that the commission agreement referred to was properly held to be against public policy and consequently void.

Where the architect brings suit for professional services rendered and the owner, in defending, claims negligence on the part of the architect and it appears that the builder has made advances or loans to the architect, these advances and loans are properly provable by the owner as bearing upon the question of negligence alleged in the answer, no actual fraud having been pleaded. ${ }^{13}$ So too the duties of a building superintendent are of such a nature that it is not proper that he be appointed by or controlled by the contractor; and

13 Gilman v. Stevens, 54 Howard's Prac. (N. Y.) 197. 
the inconsistency of the two positions is such that a contract for the employment of the contractor as superintendent of his own work will not be implied. ${ }^{14}$

If the architect accept employment from the contractor or builder this act on his part will in at least one jurisdiction be held to relieve the owner from any liability based on claims for extra work; ${ }^{15}$ and where the architect prepared the plans and specifications and thereafter was made the contractor for the erection of the building, he was not allowed to claim that a defect in construction was one of plans and specifications and not of building, since he was responsible both for plans and for construction. ${ }^{16}$

$\S 5$. Limitation of Rule-Estoppel of Owner. -While it has been seen that no private agreements or understandings between the architect and the builder will be countenanced, it should be noted, in limitation of the general rule, that, in cases where the circumstances are or must be known to the owner, the mere existence of an agreement between the architect and the builder will not be allowed to be interposed by the owner as a bar to a recovery by the architect for his services. Thus where the owners employ an architect to superintend the construction of a building of which he is, also, one of the contractors,

144 Friedland v. McNeil, 33 Mich. 40.

${ }^{15}$ Day \& Co. v. Pickeris

County, 53 S. Carolina, 46 at

p. 50 .
18 Louisiana Molasses Co. v. Le Sassier et al., 52 La. Ann. 2070. 
they are not allowed in an action by the architect to recover for his services as such superintendent, it appearing that the services have been properly performed, to plead, in defence that, by reason of his occupying the two inconsistent positions of architect and contractor, a recovery is barred on the grounds of public policy. ${ }^{17}$ Similarly, the contract of an architect with a builder, made with the knowledge of the owner and attached to the original building contract and recorded, is not to be considered as void unless actual fraud or deception be shown. ${ }^{18}$

$\S 6$. Assumption of Good Faith.-While the courts will not encourage or countenance any act by the architect inconsistent with his position of trust and responsibility they are, nevertheless, inclined to consider the architect, by reason of the very nature of his profession, honorable and single-minded in his employer's interest until the opposite be shown, and will not adopt a strained construction of his natural and entirely honorable acts. In accordance with this position a French court has refused to presume that the architect was employed by the builder from the fact that the builder went to the architect to see the plans or to borrow them, ${ }^{19}$ and from the comparatively infinitesimal number of cases in England and in this country in which any improper conduct on the ${ }^{17}$ Shaw v. Andrews, 9 Cal. al.; Hayne v. Gray; 125 Cal. 73.

18 Orlandi et al v. Gray et 372.

19 Poitras v. Deslauriers, 4 Rev. Leg. 375 . 
part of the architect has appeared, it is evident that the architectural profession may, with no small degree of satisfaction, view the record for loyalty to its ethics, to its duties and to its responsibilities, established by its individual members. 


\section{CHAPTER II}

\section{THE ARCHITECT AS AGENT OF THE OWNER}

§7. Importance of Agency Relationship.There is probably no phase of the whole subject of architecture which presents more questions for legal determination and none presenting situations of more difficulty and requiring more careful handling by the architect, not only in the interest of his client but in his own interest as well, than that dealing with the character, scope and effect of the agency of the architect.

In employment necessitating merely the preparation of plans and specifications, or the giving of expert advice, and in all matters of mere consultation or dealings with the client alone, the question of agency does not arise, but the moment that, as in the ordinary case, there is added the duty of superintendence, or dealings in behalf of the owner with the builder or third parties, the question of agency becomes at once of vital importance; and the directions to the contractor in regard to the work, the allowance of extras, the giving of certificates, the changing of the contract in any detail of construction, material, or otherwise, all are at once involved.

§8. Agency, Express and Implied.-The 
agency of the architect may, broadly speaking, be either express or implied. Where express, that is where the authority has been conferred in definite terms, it may be either written or oral; where implied and where, consequently, there is no formal agreement either written or oral by which to determine and measure the extent and character of the authority conferred, the question of the architect's agency will be determined by the ordinary principles of the law of agency modified as they may be by circumstances, and by the customs and rules governing the practice of the architectural profession. When the terms are express, whether written or oral, no amount of custom will justify a departure from them-assuming of course that there are no provisions which are illegal or opposed to public policy - and the terms of the authority delegated must be strictly respected and adhered to and will be disregarded or exceeded by the architect at the immediate risk of his incurring a direct personal liability. ${ }^{1}$

§9. Extras.-Of the many questions which arise in connection with the agency of the architect there are none, probably, of more vital interest to the owner, to the architect, and to the builder, than those which relate to the matter of

1 Homersham v. Wolverhampton Water-works Co., 6 Exch. 137; Thayer v. Vermont Central Railroad Co., $24 \mathrm{Vt}$. 440; Vanderwerker et al. v. Vermont Central Railroad Co., 27 Vt. 125, Id. 130; Herrick v. Estate of Sewall Belk- nap et al., 27 Vt. 673; Ahern v. Boyce, I9 Mo. Ap. 552; Woodruff v. Rochester and Pittsburgh Railroad Co., I08 N. Y. 39; Weggner v. Greenstine, II4 Mich. 3Io; Redfield on Law of Railroads, 6th ed., vol. I, p. 430 . 
extra work. Almost invariably, before the contract has been finally completed, some extra work becomes necessary. It is in the interest of all concerned that the respective rights and liabilities of the parties in this connection be as clearly understood as possible. The owner should understand them that he may not be put to needless expense; the builder that he may not be placed in a position, where, after proceeding in good faith with extra work, he finds he can not recover for the work which he has done; and the architect should understand them, both that he may safeguard the interests of his client and that he may not himself incur a personal liability to pay for extra work performed as the result of an authorization given by him, but which he had no power or right to give.

In every case where the contract contains a clause or clauses designed to protect the owner from claims for extra work, both the architect and the contractor will do well to proceed most cautiously, the one in authorizing and the other in performing any extra work, in any manner inconsistent with a strict interpretation of the contract provisions.

In a leading case already referred to ${ }^{2}$ a construction company contracted with the defendant, a railroad company, to construct a portion of its road. The construction company in turn made a contract with a third company to complete a certain portion of the section of the road covered by

2 Woodruff v. Rochester \& Pittsburgh R. R. Co., 108 N. Y. 39. 
the contract between the construction company and the railroad company. The third company in turn sublet a portion of the work undertaken by it, to the plaintiffs. Included in the terms of the subcontract was the following: "Extra Work-nor shall any claim be allowed for extra work unless the same shall be done in pursuance to a written order from the engineer in charge and the claim made at the first settlement after the work was executed, unless the chief engineer, at his discretion, should direct the claim or such part as he may deem just and equitable to be allowed." The plaintiffs in performing their work were called upon to do considerable excavating which was necessitated by the sides of the cut which they were making caving in on a number of occasions. For this work they claimed extras and the proof tended to show that they did the work at the request of the engineers in charge. There was no evidence that these engineers had any special authority whatever from the defendant to bind it for this work, or to enter into any contract on its behalf relative thereto. Neither did it appear that the defendant had ratified the agreement alleged to have been made with the plaintiffs by the engineers. The Court, after referring to the terms of the contract with reference to extra work and above quoted, said:

"This was one of the terms of the contract and we are unable to perceive that the engineers had any power or authority to alter or change it. It was inserted in the contract to protect the defendant from claims for extra 
work which might be based upon oral evidence, after the work was completed and when it might be difficult to prove the facts in relation thereto. If the engineers in charge had an unlimited authority to change the contract at their will, and to make special agreements for work fairly embraced therein, then the defendant had very little protection from the reduction of their contract to writing. If these engineers were the agents of the defendant, they were its agents with special powers, simply to do the engineering work and to superintend and direct as to the execution of the contract. But they had no power to alter or vary the terms of the contract or to create obligations binding upon the defendant not embraced in the contract."

To state the rule in slightly different form: "Where the contract contains express provisions that no allowance shall be made against the company for extra work unless directed in writing under the hand of the engineer or some other person designated, or unless some other requisite formality be complied with, the party who performs extra work, upon the assurance of any agent of the company, that it will be allowed by the company, without the requisite formality, must look to the agent for compensation and can not recover of the company, either at law or in equity." 3

3 Redfield on the Law of Railroads, 6th ed., vol. I, p. 430; White v. San Rafael and San Quentin R. R. Co., 50 Cal. 4I7, holding a verbal order for extra work to be of no effect where the contract, while providing that the engineers may direct alterations and additions, also provides that no payment for extra work shall be made, unless the latter has been ordered in writing by the engineer; Kirk v. Guardians, etc., 2 Phila. 640, I Redfield Am. R. R Cases, 305. 
It must be clearly understood that inasmuch as the agency of the architect is limited by the terms of the contract between himself and his client, the fact that he is employed as architect does not in itself constitute him the general agent of the client. ${ }^{4}$ The owner may constitute the architect his general agent for all purposes and by declaring him broadly to be "the agent of the owner" invest him thereby with authority to bind the owner for extras and for alterations, ${ }^{5}$ but the general rule is entirely clear that an architect engaged to superintend the construction of a building must see that the contract is carried out in accordance with its terms, and has no right whatsoever, in the absence of special authorization, to change, to alter, or to modify, the terms of the contract between the owner and the builder, nor to make new contracts involving additional expenses, nor to make any alterations in the plans and specifications, nor to authorize extra work or material other than that specified in the original contract. $^{6}$

1 Starkweather v. Goodman, 48 Conn. IOI ; Crockett v. Chattahoochen Brick Co., 95 Ga. 540; Adlard v. Muldoon, 45 I11. I93; Coombs v. Beede, 89 Me. 187; Leverone v. Arancio, 179 Mass. 439; Weeks v. The Rector, etc., of Trinity Church, 56 (N. Y.) A. D. I95; Dodge v. McDonnell, I4 Wis. 553.

- Langley v. Rouss, 85 (N. Y.) A. D. 27; Kimberly, v. Dick, L. R. I3 Eq. I. ${ }^{6}$ Fireproof Building Co. v. First National Bank, 54 Super. Court (N. Y.) $5 \mathrm{II}$; Glacius et al. v. Black, 50 N. Y. I45; Dillon v. City of Syracuse, 5 Silv. Supreme Court (N. Y.) 575, 9 N. Y. Supp. 98,29 N. Y. St. Rep. 9r2; Fitzgerald v. Moran, I4I N. Y. 4I9; Woodruff v. Rochester, etc., R. Co., I08 N. Y. 39; Richard v. Clark, 43 Misc. (N. Y.) 622; Stark- 
$\S$ Io. Illustrations of Rule.-A leading case on this whole agency question, decided in Connecticut, as early as I880, arose on the following state of facts: a builder entered into a written contract with the defendant whereby he agreed to furnish the materials to build a house for the defendant in accordance with specified plans and specifications and for an agreed compensation. It was provided that all the materials and work should be accepted by the architect, who was specified, and that the latter should superintend the construction of the building. The builder, in entire good faith and under the direction of the architect, performed certain extra work, which varied from

weather v. Goodman, 48 Conn. IoI ; Gray v. La Societe Francaise, etc., I3I California, 566; Maldard et al. v. Moody et al., I05 Ga. 400 ; but see Smith et al. v. Farmers Trust Co., 97 Iowa II7, to the effect that where the contract expressly stipulates that excavations shall be made under the direction of the architect specified, a variation from the plans, by direction of the architect, although without the knowledge of the owner, will not justify any deduction from the contract price. Adlard v. Muldoon, 45 Ill. I93; Campbell v. Day, 9o Ill. 363; Watts v. Metcalf, $23 \mathrm{Ky}$. L. Rep. 2189, 66 S. W. Rep. 824; Lewis v. Slack, 27 Mo. App. II9; Bond v. The Mayor, etc., I9 N. J. Eq. 376; Mayes v. Reg, 23
Canadian Sup. Ct. 454, affirming 2 Exch. 403; Jones v. Reg., 7 Can. Sup. Ct. 570; Reg. v. Stars et al., Can. Sup. Ct. I I8; Baltimore Cemetery Co. v. Coburn, 7 Maryland, 202; Stuart v. City of Cambridge, 125 Mass. I02; McIntosh v. Hastings, 156 Mass. 344; Day v. Pickens Co., 53 S. C. 46; Dodge v. McDonnell, 14 Wis. 553; Wagner Co. v. Cawker, II 2 Wis. 532; Fontano v. Robbins, 22 App. Cas. (D. C.) 253; Sharpe v. San Paulo, etc., Co., 27 L. T. Rep. N. S. 699, L. R. 8 Ch. App. 605 (notes), affirmed in L. R. 8 Ch. App. 597; Rex. v. Peto, r Young \& Jarvis 37; Cooper v. Langdon, 9 Meeson \& Welsby 60; Hudson Bldg. Contracts, vol. I, sec. 3 
and was in addition to the work outlined in the plans and specifications. When the house was nearing completion, the builder furnished the defendant with a written statement of the extra work and material and the defendant at that time made no objection to it, although it does not appear that he ratified it. It appeared also that at the time when the builder gave the defendant the written notice referred to, the extra work had been actually performed upon and the materials had been actually used in the construction of the building and become a part thereof, and could not be withdrawn. Subsequently, other extras were ordered by the architect and furnished by the builder. It did not appear that at the time when the builder rendered his first bill for extras, he suggested to the defendant the possibility of more extras being needed or indeed that any thought was given to this point by either of the parties. The Court below gave judgment for the plaintiff and the defendant appealed. The higher court reversed the judgment, holding:

"The contract sets forth the extent of Easton's agency for the defendant; he is only to see that the materials and workmanship are in accordance with the specifications. There remained no opportunity to Smith to extend that power by inference, and when he furnished materials for or performed labor upon the house in excess of the specifications upon the order of Easton, he assumed the risk of ratification by the defendant.

Nor is the defendant estopped from insisting upon this contract limitation upon Easton by the fact that when 
the house was nearly completed he received in silence a statement of work, and materials not specified in the written contract, which included some which he had not ordered; for these had been wrought into the building and were then beyond possibility of withdrawal by Smith, however strongly the defendant might have protested against payment for them. It is very clear therefore, that, as to these extras, Smith was not led into any action resulting in loss to him by the failure of the defendant to make the objection.

But it is said that other extras were afterwards ordered by Easton and furnished by Smith, and that, whatever might be the effect of the defendant's silence upon the extras already furnished, he ought to be regarded, by reason thereof, as authorizing the extras afterwards ordered. But it does not appear that Smith at that time suggested to him that there might be other extras ordered by Easton, or that the matter was thought of by either of them. Besides the question whether the defendant intended to influence the future action of Smith, or was guilty of such gross negligence that he could be chargeable with that intention, and the further question whether Smith was influenced by his conduct, were both questions of fact and not of law, and it is impossible for us to find these facts when the court below has failed to do so." 7

In another leading case in Massachusetts, the plaintiffs offered to show that they did the certain work for the value of which the suit was brought under the direction of the defendant's agent, the architect; that they stated to the latter that the work was not included in their contract and that he told them "to go ahead and do the work as he directed and they would be paid for it." The Court excluded this evidence, holding that

? Starkweather v. Goodman, 48 Conn. Ior. 
"the written contract carefully provides that any additions to or deviations from the plans or specifications shall be directed in writing by the committee or architect, and that 'it is expressly agreed that no alterations or additions are to be paid for unless so directed in writing.' No evidence was offered of any waiver of this provision by the defendant, or of any authority in the architect to waive it. This clause was intended to protect the defendant against claims for extra work under alleged oral directions or contracts. If the evidence offered can be construed to show an oral promise by the architect, founded upon a sufficient consideration, to pay for the work sued for as extra work, it was made without authority, and is not binding upon the defendant." 8

The same rule has been applied, and vigorously, in New York State. In one instance, a building contract provided in the specifications that Kings Winsor cement should be used and the work carried out under the direction of a certain superintendent. Elsewhere in the specifications it was provided that the cement should be mixed "with equal parts good sharp and dry sand." There was also a provision that in the event that any dispute should arise respecting the true construction of the specifications, the matter should be decided by the architect, "whose decision shall be final and conclusive." The plaintiff, a subcontractor for the plastering work, filed a mechanic's lien for his services and materials, and brought an action to foreclose the same. On the trial of the action, it appeared that the cement mixture used was two parts sand and one part cement. The plaintiff

8 Stuart v. Cambridge, 125 Mass. 102. 
testified that the variation from the specifications in the preparation of the mixture was in accordance with the direction of the superintendent. A letter was also introduced which the architect had written to the plaintiff, in which he stated that the plaintiff was not doing the work in accordance with the contract and was not following the instructions of the superintendent, and in which he directed him to follow those instructions "to the letter." The Court below dismissed plaintiff's complaint and the Court of Appeals by Chief Justice Andrews affirmed the judgment below in the following language:

"There is some evidence tending to show that the variation from the specifications in the proportions of sand and cement was directed by the superintendent of King \& Company, but it is plain that the provision that the plastering should be done under the direction of the superintendent of King \& Company had relation to the manner of applying the plaster, and gave him no authority to change the component parts of the mixture specifically prescribed. . . . It is difficult to see how a letter complaining of the work as not complying with the contract could be construed as an authority to follow the instructions of the superintendent of King \& Co., in respect of a matter fixed by the specifications and a departure from which in reducing the proportion of cement would not be of advantage to the owner of the building." *

In another New York case the plaintiff brought action to recover for work done and materials furnished in a building constructed by the defendants, under the direction of their architects.

๑ Fitzgerald v. Moran et al., I4I N. Y. 4I9. 
The question arose whether the architects had made, or had in any case a right to make, with the plaintiff, a new contract relative to the work and binding upon the defendants. It appeared that the architects were employed by the defendants to prepare the plans and specifications, to secure estimates, and to superintend the erection of the building.

The Court held that "the employment as architects to superintend the building and see that the persons with whom the defendants had contracted performed their contracts would not give the architects authority to make new contracts." 10

$\S \mathrm{I}$. Other Limitations on General Agency.In the absence of provisions giving to him specific authority so to do, the architect can not employ a new contractor to do work already undertaken by the contractor originally chosen, ${ }^{11}$ nor can he substitute, either as respects the performance of the work or the payment therefor, a subcontractor for the principal contractor, nor does the mere fact that the owner happens to see the work being done by the subcontractor serve to make the owner liable; for, in the absence of special circumstances, it will be presumed that the owner has the right to suppose that the work is being done for the principal contractor. ${ }^{12}$.

${ }^{10}$ The Fireproof Building 12 Campbell v. Day, 90 Ill. Co. v. The First National 363; Bouton v. Supervisors of Bank, et al., 54 N. Y. Super. McDonough County, 84 Ill. Court, 5 II. 384 ,- -but note that this is a 363.

${ }^{11}$ Campbell v. Day, 90 Ill. case of public rather than of private agency. 
So, in the case of a public corporation at least, certificates cannot be given to subcontractors, ${ }^{13}$ and neither certificates nor orders issued must vary from the form specified in the contract,-if a form be specified. ${ }^{14}$ Similarly, when the architect is, either orally or by the terms of the written contract, given authority to certify extras and authorize alterations, the client will not be held liable unless the architect complies with and keeps strictly within the terms of the authority conferred. ${ }^{15}$

Just as the architect has no right in the absence of express authority to order extras or alterations, so too, in the absence of such express authority, he has no right to allow the contractor to vary from the terms of the contract either as respects materials or construction, or as to any of its substantial details or provisions, nor to allow any detail of construction or material to remain which is contrary to the contract terms and provisions. ${ }^{16}$ It has been held also that the architect has no general authority to exercise a supervision

13 Bouton v. McDonough County, 84 Ill. 384.

14 Mills v. Weeks, 2I Ill. $56 \mathrm{r}$.

15 Ahern v. Boyce, I9 Mo. App. 552; Woodruff v. Rochester, etc., R. Co., 108 N. Y. 39; Commune de Calombier. Saugnieu v. Duchez et Savoye. Dalloz Jurisprudence Gènerale, 1883, part 3, p. 92.

${ }^{16}$ Glacius et al. v. Black, 50 N. Y. 145; Bonesteel v. The Mayor, etc., of N. Y., 22 N.Y.
I62; Burke v. City of Kansas, 34 Mo. App. 570; Starkweather v. Goodman, 48 Conn. Ior ; Stuart v. City of Cambridge, 125 Mass. I02; Cooper v. Langdon, 9 M. \& W. (Messon \& Welsby), 60; Bond v. The Mayor, etc., 19 N. J. Eq. 376; Clark on Architects, p. 87; Wagner Co. v. Cawker, II2 Wis. 532; Hudson, Building Contracts, vol. I, §3, p. I6. 
over the letting of subcontracts or the employment of workmen, ${ }^{17}$ nor yet to receive a notice of the assignment of the building contract so as to bind the owner. ${ }^{18}$

$\S$ 12. Special Agency-To Be Carefully Exercised.-It must be understood that all of the limitations on the powers and authority of the architect, referred to, are limitations upon his powers and authority under his general agency, and that if, orally or in writing, he be authorized to exercise a special authority, or be appointed broadly the general agent of his employer as to all matters relating to the contract or building, his authority will be enlarged accordingly. Thus, for instance, he may be given, specifically, full discretion and authority to pass upon and order extras or alterations, or accept work of a different character than that specified, or to change contractors, or to vary the terms of the contract between his employer and the contractor in such details as he may think best. If he be given such special discretion and authority, he will be justified in exercising it accordingly. He cannot, however, be too careful to ascertain before he acts the exact extent and scope of his authority, for it often happens that provisions delegating to him special authority and which he may consider justify him in assuming certain authority, are legally to be construed as so limited by the other general conditions of the contract, or by the rules of agency, as to make his
17 Lewis v. Slack, 27 Mo. App. II9.
18 Renton v. Monniere, 77
Cal. 449. 
actual authority and discretion much less than he supposes it to be.

Thus a provision giving to the architect the power to make changes in plans or specifications, has been held not to contemplate or authorize any radical changes from the plans or specifications, but only such incidental changes as may fairly be considered to be necessary to complete the work, in accordance with the general intentions of the parties. And where a contract provided that a dam to be constructed was "to be built of masonry" and then provided that the engineer in charge could "make alterations in the line, grade, plans, form, position, dimensions, or materials," it was held that the authority was insufficient to authorize the engineer to change the dam from one of masonry to an earthen dam with a masonry core. $^{19}$

§ I3. Estoppel of Orener.-It must not be supposed that the owner can, under any and all circumstances, when the architect has exceeded the limits of his agency powers, escape responsibility if by his conduct he has impliedly ratified his agent's acts, or so acted himself as to cause others to reasonably suppose that the acts of the agent were with his approval, and so estopped himself from claiming, certainly as to third parties, that the acts were in reality without his sanction or authority. So, where alterations are ordered by the architect in the presence of the owner, who

19 The National Contracting Co. v. Hudson River Water Power Co., 192 N. Y. 209. 
does not then demur or question them, the authority of the architect to order such alterations is presumed, and this even though in the contract it be provided that any orders for alterations must be in writing. ${ }^{20}$ Similarly if the architect, during the progress of the work, has made repeated changes in the plans which the owner has ratified and approved, and the architect makes further extensive changes and alterations, the contractor is justified, by the actions of the owner, in depending on the architect's authority as to these final changes and alterations and the owner, who has received the benefit thereof, cannot successfully defend an action by the contractor, on the ground that the architect has exceeded his authority. ${ }^{21}$

The architect in his capacity as superintendent, may be considered the agent of the owner within the scope of his authority, ${ }^{22}$ but he is the agent of the owner for the purposes only of the contract in connection with which he is employed. ${ }^{23}$

$\S$ I4. Delegation of Powers-The General Rule.-As in the case of an attorney or special trustee, so in the case of an architect, his employment is based upon personal trust, and upon confidence in his honesty, ability and skill. He cannot

20 Perry v. Levenson, $82 \mathrm{~N}$. Y. A. D. 94; affirmed, without opinion, 178 N. Y. 559.

21 Jackson Architectural Iron Works v. Rouss, 39 St. Rep. 359, 15 N. Y. Supp. 137-judgment affirmed without opinion, 133 N. Y. 538.
22 Vanderhoof v. Shell, 42 Oregon 578; Brin v. McGregor (Tex. Civ. App. I898) 45 S. W. 923; Kilgore v. Northwest Texas Baptist Educational Society, 89 Tex. 465.

23 Richard v. Clark, 43 Misc. (N. Y.) 622 . 
therefore, without express authority or permission so to do, delegate his authority to another. This is in accordance with the old agency maxims of delegatus non potest delegare and delegata potestas non potest delegare. In one State at least these have been so strictly applied as to forbid the architect from delegating his authority as arbitrator to his partner without the consent of his employers. ${ }^{24}$

§ 5. Limitation of Rule.-When a firm is employed, as a firm, and dependence is not placed specially upon one member of the firm, the foregoing rule would not apply, and where an architect's partner has been in charge of the work and has been recognized by both the owner and the contractor as being so in charge, he can by signing an arbitration provided for in the contract bind both parties, although his individual name does not appear in the firm title and is not mentioned in the contract. ${ }^{25}$ In any event if the parties mutually consent there can be no objection to the architect delegating his authority to another, and, of course, the parties themselves may waive conditions in the contract which, without express authority, the architect could not waive. ${ }^{26}$

24 Wright v. Meyer (Tex. Civ. App. 1894), 25 S. W. Rep. II 22.

25 Wymard v. Deeds, $2 \mathrm{I} \mathrm{Pa.}$ Super. Ct. 332.

${ }^{26}$ Smith v. Molleson, $148 \mathrm{~N}$. Y. 241 ; Wagner Co. v. Cawker, 112 Wis. 532; Bannister v. Patty's Exec's, 35 Wis. 215;
McPherson v. Rockwell, 37 Wis. 159; Boden v. Maher, 105 Wis. 539; Wambald et al. v. Gehring, 109 Wis. 122; Page on Contracts, \& 1468; Weatherhogg v. Board of Commissioners of Jasper County, 158 Ind. I4. 
The rule delegata potestas non potest delegare must not be taken as meaning that there are no details of the work which an architect can properly delegate to others, for it is manifest that it would be impossible, as a modern architect's office is conducted, for the architect to personally attend to every detail, no matter how slight or trivial. There are many duties, of a more or less ministerial and clerical character, which can and indeed must be delegated, if the work is to be carried forward with despatch, and without undue interference with other work in hand. The general rule is well stated in an early English decision where it is said that "Where a man employs an agent relying upon his peculiar aptitude for the work intrusted to him, it is not competent to that person to delegate the trust to another. But, where the act to be done is of such a nature that it is perfectly indifferent whether it is done by $\mathrm{A}$ or by $\mathrm{B}$, and the person originally intrusted remains liable to the principal by whomsoever the thing may be done, the maxim above referred to (delegata potestas non potest delegare) has no application." ${ }^{27}$ In another and comparatively recent English case, in which the decision of the Master of the Rolls was upheld, the statement of facts and decision are in point: "By the terms of the contract the architect could order the removal of any materials used in the building that appealed to him as not up to the specified quality. What the architect actually did

${ }^{27}$ Hemming v. Hale et al., 7 C. B. N. S. (Common Bench, New Series) 487. 
was to examine the wood on the ground, and, finding that it was not of the required quality, he directed the clerk of the works to mark the timbers already put in the roof of the sorting house to which he objected. Upon that gentleman's report, the architect framed his certificate, and the question was whether in these circumstances the architect could be said to have adjudicated on the matter. It was perfectly obvious as a matter of business that one could not expect an architect to go into every detail himself and he (the Master of the Rolls) had no hesitation in holding on the authorities that the architect, having himself first ascertained that the timber being used was not of the stipulated quality, was perfectly entitled to delegate the duty of particularizing which of the timbers had to be removed." 28

$\S$ I6. Due Care Required in Delegation of $A u$ thority.-In delegating his authority the architect should be careful to delegate it to one in whom he can reasonably feel entire confidence as by placing more than a reasonable amount of confidence in the clcrk to whom the authority is delegated he would, by reason of his negligence in so doing, render himself liable for any damages occasioned the owner by reason of the incapacity of, or improper performance of his duties by, the clerk. ${ }^{29}$ The architect must remember that it is always he

28 A. M. Brice "The Legal Authority of the Architect as an Agent," quoting Graham v. The Commissioner of Works,
Builder, Nov. I5, I902, p. 456. 29 A. M. Brice, supra, citing Lee v. Lord Bateman. Times, October 3I, I893. 
himself who is the agent of his client and that while he may delegate such details as it is proper and reasonable that he should, the responsibility remains his and the owner has the right to look to him and to him alone for the proper performance of his duties as architect.

§ I7. Power to Act in Emergencies.-The question often arises whether, under circumstances of sudden necessity or exigency, the architect may order extra work to be done or steps taken, under the powers conferred upon him in the ordinary case. If a beam break, for instance, is the architect authorized to have emergency measures taken, at once, and without consultation with the owner, for the safety of the other details of the work and of the building?

It has been stated that whether an agency "is conferred in the one way or the other (viz., orally, or in writing), it is, unless the contrary manifestly appears to be the intent of the party, always construed to include all the necessary and usual means of executing it with effect." 30 And in a leading case in New York State, the rule is held to be that "whatever may be necessary to complete an act an agent is authorized to perform is included within the authority of the agent." 31 Following this rule and the rule that an architect has authority to proceed in the usual way, ${ }^{32}$ it has

80 Story on Agency, 9th ed., $\S 58$, page 71 .

\$1 Robinson v. Springfield Iron Co., 39 Hun (N. Y.) 634.
32 Moon v. Guardians of the Poor, 3 Bingham's N. Cas., 814 . 
been stated that an architect is able in an emergency and unforeseen circumstances, to bind his employer for extra work and materials and to disregard the letter of the original agreement where such extra work and materials, although a variance from the terms of the agreement, are, nevertheless, necessary to secure the safety and the security of the building. ${ }^{33}$

It does not seem safe, however, to accept this as the approved general rule. The Indiana case of Gibson County v. Matherwell, etc., Co., referred to by Mr. Clark, as above noted, is itself decided on a state of facts showing that the building was accepted by the owner, and in both this and other respects does not seem to justify the broad doctrine for which it has been cited, and there are varying views in most respectable jurisdictions. ${ }^{34}$

While the courts may be inclined to stretch a point here and there to relieve the architect where he has acted, probably for the best, under circumstances of sudden necessity, they recognize, nevertheless, the danger of any general opening of the door, to an extent which might be taken advantage of to unduly broaden the rules which experience has shown it to be wise to adopt in limitation of the implied powers and authority of an agent.

$\S$ I8. Dangers of Implied. Authority.-An architect in ordering extras or alterations or ad-

${ }^{33}$ Clark on Architects, p. 82, citing Gibson County v. Matherwell Iron, etc., Co., I23 Ind. 364 .
34 Stuart v. Cambridge, I25 Mass. 102; compare Art. 18, general conditions, Appendix B, p. 230. 
ditions, by reason of the very fact of his employment as the agent of the owner, must, in many cases, impliedly represent himself as having authority to authorize the extras and changes directed, and, as it has long been recognized that an architect falsely representing himself as having authority to bind his principal for work and materials incurs a personal liability therefor, ${ }^{35}$ it is apparent that, with the best of intentions, the architect may, by a little excess of zeal or lack of care on his part, incur a loss far exceeding any possible compensation received by him from the work in hand. So, in the case of extras, he has no implied authority to authorize as extras work which should have been included or shown in his own specifications or drawings, nor work which, while not specified, is absolutely essential to the completion of the contract and for which it should have been the duty of the builder to make allowance in his estimate, knowing it to be essential; nor yet, may he, where his drawings are not practicable, order as extras the work necessary to make them practicable. ${ }^{36}$

$\S$ 19. General Precautionary Suggestions.There is but one way in which the architect can properly protect himself from the danger of incurring personal liability under one or another phase of his position as the agent of his client, and that is to exercise the utmost care not to ex-

${ }^{85}$ Randell et al. v. Trimen, I8 C. B. (Common Bench) 786.
${ }^{\circ} \mathrm{A}$. M. Brice, "The Legal Authority of the Architect as an Agent." 
ceed the express or implied authority which he knows himself to possess; not to act on any point where there is the slightest doubt of his full authority to act, without securing that authority; to take nothing for granted, but to be guided by the contract and by the authority which, orally or in writing, he has received; to refuse to take the chance that the owner will ratify what has been done, where it is possible to in any way communicate with the owner and secure his approval and assent; and wherever a point of ambiguity or uncertainty arises, to ascertain, before acting, just what construction, legally, is to be placed upon the provisions by which his authority and liability are specified, governed and determined.

It may well be that, as a practical matter, in many cases, a quick decision will be necessary and that it will be impossible to secure the approval of the client in advance, but so far as possible, nothing should be taken for granted or assumed on the point of agency if the architect would avoid complications and personal loss. If the contract or understanding under which he is acting does not clearly confer upon him such authority, express or implied, as a particular development may necessitate, let him, before acting, secure that authority if this be a possibility, in writing if practicable, if not, orally, in person or by telephone, in some form in any event. Only by doing this will he be protected, and only thus will he avoid the danger of suffering sooner or later, and, in all likelihood sooner rather than later, a loss which will 
more than counterbalance any advantages which he may have secured by taking chances in the past and by trusting merely to the sense of fairness of those employing him to save him harmless. And let him always, under any circumstances, be very critical of any authority which is by implication rather than express, even though the implication seem to his mind entirely clear and inevitable. 


\section{CHAPTER III}

\section{THE COMPENSATION OF THE ARCHITECT}

$\S 20$. Introductory.-The right of the architect to receive compensation for his work is naturally a matter of prime importance to him. If he is to be in a position to properly protect his rights in this connection, and at the same time avoid unnecessary and expensive misunderstanding and possible litigation, he should understand the theory upon which his right to compensation is based and the circumstances under which he may or may not rightfully demand and recover compensation for services rendered.

Matters which, to the lay mind, may seem of little or no importance may, in fact, prove to be determining factors in deciding whether or not the claim of the architect for compensation is valid and enforcible. A very few words or a very simple writing at the proper time may make his right to compensation entirely clear, while a failure to speak the words or to secure the writing may mean that, after the work of the architect has been done, some technical or other objection may be successfully urged as a bar to his recovery.

It is no less desirable that the owner shall un- 
derstand the terms and effect of his contract with the architect and the rules governing his own liability to reimburse the latter for services rendered.

$\S 2 \mathrm{I}$. Theory of Recovery-Contract and Quantum Meruit.-The recovery. by an architect for services rendered may be based either upon the theory of direct contract or upon the theory of what is known in the law as quantum meruit. If based upon the contract, the recovery is for the specified amount which by the terms of the contract the owner has agreed to pay the architect as his fee. If based upon quantum meruit the recovery is not upon the theory of a definite contract price, but for the reasonable value of the work done and services rendered. In the ordinary case of a suit for goods sold and delivered, for instance, the recovery may be for a certain number of yards of goods at an agreed price, of, say, one dollar a yard, or, if no price has been agreed upon, and the goods have been delivered and accepted by the defendant, the recovery may be for the reasonable value of the goods delivered, which may be a dollar a yard, or more or less. So, in the case of personal services rendered, if a definite commission or rate of compensation has been agreed upon, the recovery will be in accordance with the commission and rate thus established. If there has been no such definite agreement the recovery will be for such amount as will represent the reasonable value of the services rendered. 
It will be seen that there is a vast difference between these two theories of recovery. In the case of a definite contract the architect need not prove that the services are reasonably worth the amount claimed-all that he need prove is that the client agreed to pay him a certain sum in compensation for his services, that the services have been performed and that the agreed compensation has not been paid and is due accordingly. If he cannot prove such definite agreement then it is that he must fall back upon the quantum meruit count and ask compensation for the reasonable value of his services. If there has been a definite contract the fee agreed upon is, of course, just as controlling upon one of the parties as upon the other; that is, the architect, if he agree to serve for an agreed compensation cannot claim more, on the theory that the services are worth more, and, disregarding the existence of the contract, elect to recover on quantum meruit instead; and, similarly, the client cannot, under these circumstances, pay less than the amount agreed, where the services have been duly performed in accordance with the terms of the contract. If there be no contract a recovery may be had for the full reasonable value of the services rendered irrespective-except in so far as this may be considered in determining the reasonable value-of whether their value is more or less than the amount which the architect might have been willing to accept, if a definite agreement had been entered into. 
In a case where the architect and owner enter into a definite contract covering the amount of the compensation to be paid, and the contract is performed by the architect and the building is completed in the ordinary course and without differences arising, there will be little room for any complications in regard to the architect's fee. But when the cases are reached wherein no definite contract is made, and preliminary sketches are prepared with no statements made and nothing said in regard to the matter of compensation; or, where special conditions regarding the character of the building or its cost are stipulated by the owner as terms of the contract; or where plans are submitted in competition, or where, after ordering the preparation of sketches and plans and specifications, the owner for one reason or another decides not to proceed with the contract, very different situations are presented-situations which in their very nature make it quite possible, and indeed probable, that differences of opinion will arise, as to whether any fees are payable, and if so, to what extent they are payable and in what amounts.

$\S 22$. Recovery in Absence of Special Conditions or Agreement.-An architect is no more an eleemosynary institution than any other professional or business man, and, in general and in the absence of such other circumstances or conditions as are noted hereafter, where a client requests an architect to prepare and furnish plans and the latter does so, he is entitled to be paid for his 
services. ${ }^{1}$ And unless at the time the order for the plans is given and the work on them is done it is agreed directly, or impliedly from what is said, that they are submitted on approval, or on conditions specified as to their acceptance, the client, by requesting their preparation and by receiving them, incurs a liability to pay for such of them as may be completed before the order is countermanded, and this entirely irrespective of whether the plans are ultimately used or not. ${ }^{2}$

$\S 23$. Effect of Specified Conditions.-Where the owner gives to the architect specific directions in regard to the character of the plans desired, the architect cannot recover unless the plans are made in accordance with the directions received, ${ }^{3}$ and the architect will at once imperil his right to recover for his services, if he disregards in any way any conditions which the client may have specified, in regard to the work to be done, or as terms of the contract between them.

$\S 24$. Conditions $\mathrm{Re}$ Cost.-There is no point perhaps in the question of compensation which should be approached more carefully by the architect, or which will more often be taken advantage

1 Smithmeyer v. U. S., $25 \mathrm{Ct}$. court below; Nelson v. Cl. 48I, judgment affirmed 147 Spooner, 2 F. \& F. 6I3; Kutts U. S. 342; Maas v. Hernandez, v. Pelby, 20 Pick. (Mass.) 48 La. Ann. 264, I9 So. 269; 65; Marcotte v. Beaupre, I5 Canfield (New England Monu- Minn. 152; Driscoll v. Indement Co.) v. Johnson et al., pendent School District, 6I I44 Pa. St. 6r, 22 Atl. 974. Iowa 426.

2 Pierce v. Thurston, 40 App. ${ }^{3}$ Smith v. Dickey, 74 Texas Div. (N. Y.) 577 , reversing 61, II S. W. 1049. 
of to prevent recovery by him for his services, than the question of the cost of the building to be erected. It is entirely natural that the intending builder, when he first interviews the architect, should mention the probable cost which he has in mind, and it is natural too that the architect, in conferring with him, should make to him some statement, more or less definite, regarding the amount which a building of the character described by the client will probably cost. Any statements by the architect, or conversations between him and the owner, which can be construed either as an implied or express condition or warranty that the building can or shall be erected for a certain sum, or which can be construed as an estimate on the part of the architect of the probable cost of the building, may be fatal to his right to recover for his services, if the client sees fit to take advantage of the situation. In all probability the condition most frequently specified by the owner is that the plans are to cover a building which shall not exceed in cost a definite specified maximum. Where such a condition is prescribed, or where as a result of what has passed between the architect and the owner, the understanding can be said to be that the cost of construction shall not exceed a certain sum, or that the plans are accepted on condition that it shall not exceed such sum, no compensation can be recovered for the plans or for their preparation in the event that, as finally submitted, they cover a building 
exceeding in cost the stipulated maximum amount. ${ }^{4}$ Again, if the architect submit estimates of the probable cost of the building, he cannot recover his fee for the plans prepared unless the cost of the building is reasonably close to the estimates submitted. ${ }^{5}$

$\S 25$. Limitation of Rule.-Under these circumstances, however, where the architect gives merely the probable cost of the building, the mere fact that the cost exceeds slightly the estimate which he has made will not in itself defeat his recovery, for it is the province of the jury to determine whether the estimate submitted by the architect is reasonably near the actual cost of the building, and the architect has a right to have this question submitted to the jury for determination. ${ }^{6}$ If, also, the architect upon finding that the cost of the building, if erected in accordance with the plans prepared and submitted, will exceed the amount stipulated by the owner as the maximum amount which the building is to cost, or will exceed the cost as given in his estimate, submit suggestions as the result of which and by following which the work can be properly done at a less cost,

4 Horgan v. New York, II4 N. Y. A. D. 555; Walsh v. St. Louis, etc., Assn., IoI Mo. 534; Ada St. Methodist Episcopal Church v. Garnsey, 66 I11. I32; Maak v. Schneider, 57 Mo. App. 431; Emerson v. Kneezel, 62 S. W. (Tex. Civ. App. Dec. 1900) 551; Smith v. Dickey, 74 Tex. 6I, II S. W.
1049; Feltham v. Sharp, $99 \mathrm{Ga}$. 260, 25 S. E. 619.

5 Moneypenny v. Hartland, I C. \& P. (Carrington \& Payne), 352, 2 C. \& P. 378; Nelson v. Spooner, 2 F. \& F. (Foster \& Finlanson) 6r3; Smith v. Dickey, 74 Tex. 6I, supra.

- Nelson v. Spooner, 2 F. \& F. (Foster \& Finlanson) 6 I3. $_{3}$ 
and at a cost meeting and consistent with the requirement as to the stipulated maximum cost or the estimate submitted, he will be entitled to his compensation.

In a leading case on this last point, decided in Iowa, the architect, in consideration of a three per cent. commission, agreed to furnish preliminary sketches and complete working drawings and specifications, to superintend the building operations and to make settlement of all accounts. He prepared the plans and specifications and was proceeding to carry out the other provisions of his agreement when the owner announced his decision not to proceed with the building. It appeared that the parties contemplated a building to cost not more than $\$ 10,000$, and that the plans and specifications as originally prepared entailed an expense in excess of $\$ 16,000$. Subsequently, finding that the cost would reach this sum and thus exceed the $\$ 10,000$ contemplated, the architect suggested certain changes which would bring the cost within the contemplated \$10,000 limit. The drawings were then accepted by the owner. The Court held that the architect could recover for his services in preparing the plans and specifications and that the fact that the drawings, as at first prepared, called for a $\$ 16,000$ building was, under the circumstances, no bar to the right of recovery. It should be noted that in the foregoing case there was a direct acceptance of the plans by the owner, which of course strengthens the position of the architect; but the doctrine, as 
laid down, is nevertheless clear, that an architect by suggesting changes whereby the cost is reduced within the amount specified may place himself in a position where the owner cannot rightfully refuse payment on the ground that the cost exceeds the amount specified or estimated. ${ }^{7}$ Of course, such suggestions for modifications, whereby a reduction in cost is to be effected, must be made in practical form, in good faith, and with reasonable promptness; they will not have the same favorable effect, from the standpoint of the interests of the architect, if made tardily or after the claim has been pressed and a recovery for services sought.

In the event that the fact that the cost exceed, in a given case, the stipulated maximum, is due to the interference of those by whom the architect is employed, and the endeavor of the latter in good faith to meet their demands in regard to the building-these demands necessitating a more costly building than contemplated-and a building of no particular character is specified, the architect may recover. $^{8}$

$\S 26$. Necessity of Delivery.-In order to entitle the architect to recover for the plans prepared it must be shown that they have been delivered or that the delivery of them has been prevented or waived by the owner. Mere preparation of them in the office of the architect, if they are not delivered to the client who has ordered them or in

7 Marquis v. Lauretson (Iowa Sup. Ct. 1888), 40 N.W. 73.
8 Coombs v. Beede, $89 \mathrm{Me}$. 187, 36 Atlantic 104. 
accordance with his directions, will not ordinarily charge him with any liability to make payment for them, inasmuch as he has not received any benefit from their preparation. ${ }^{9}$

Where an architect was directed to prepare plans for a theater, and he accordingly prepared a sketch and delivered it to the defendant, and the defendant kept it for a week and expressed his approval of it and told the architect to make the plans, and went so far as to have his builder call on the architect at the owner's request and take the plans and make and deliver to the owner an estimate based upon them, the plans were held to have been clearly delivered and the architect's right to recover for the value of his services was sustained. ${ }^{10}$

Under the foregoing circumstances, all the general elements necessary to allow a recovery were present. There was not a specific contract, but the plans were prepared by the architect at the request of the defendant and there were no special conditions upon which the defendant stipulated that payment should be made. Having taken the plans and caused the architect to perform the services in question, at his request, he could not then refuse to pay for them, and this, entirely irrespective of whether they were used by him or not.

- Kutts v. Pelby, 20 Pick. (Mass.) 65; Wandelt v. Cohen, 15 Misc. (N. Y.) 90; Resher v. Frères des Ecoles Chrétiennes, 34 L. C. Jur. 89.

10 Kutts v. Pelby, 20 Pick. (37 Mass.) 65, supra. 
$\S 27$. Delivery and Acceptance Distinguished. -A delivery to, or the receipt by, the owner of the plans, however, must not be confused with an acceptance. It is quite possible that even if they are properly prepared and delivered, the owner may, on some pretext or another, or for some reason, valid or invalid, as the case may be, refuse to accept them. If the work has been properly done and the architect has complied with his agreement, the refusal by the owner to accept will not relieve him from liability and the acceptance is not, therefore, under such circumstances, necessary to complete the right of the architect to receive compensation for his services; ${ }^{11}$ but in the event of special conditions in the agreement, or of special circumstances under which the plans are submitted, acceptance may become of prime importance. Where, for instance, plans are submitted on approval, or are submitted in competition with plans prepared by others and on the understanding that the plans which are accepted are to be the ones for which payment will be made, no recovery can be had if the plans are not accepted, inasmuch as acceptance under these circumstances, is a condition precedent to the right of the architect to recover. ${ }^{12}$

In the case, too, where an architect solicits the work of superintending the building and, of his

11 Canfield (New England Monument Co.) v. Johnson et al., I44 Pa. State 6I, 22 Atlantic 974 .
12 Audsley v. The Mayor, 74 Federal 274; Allen v. Bowman, 7 Mo. App. 29; Walbank v. Protestant Hospital, 7 Montreal Q. B. 166 . 
own initiative and not at the request of the owner, leaves sketches with the latter in the hope that his doing so may result in his securing the employment sought, and the owner returns the sketches and neither accepts them nor makes use of them, no recovery for them can be had. ${ }^{13}$ This is on the theory that the services were not rendered at the request of, or sought by, the owner, but were purely voluntary and at the instance of the architect alone, and for the purpose of inducing the owner to employ him to superintend the work. If the owner were to keep the sketches or make use of them, even though he had not sought the services of the architect in the first instance, and even though the services had not been performed at the request of the owner, payment for the sketches could be demanded for the reason that, having received the benefit of them, and retained and so accepted them, the owner could not refuse to reasonably compensate the architect for the services involved.

$\S 28$. Necessity of Actual Contract-Custom Alone Insufficient to Sustain Recovery.-In the event that no contract of any character-no meeting of their minds-either in express terms or by implication, can be established between the owner and the architect, no amount of custom or usage can place upon the owner a liability to pay for services rendered. The evidence of custom or usage may be competent either as tending to show an implied agreement to pay a reasonable com13 Allen v. Bowman, 7 Mo. App. 29. 
pensation, or, if no such implied agreement be shown, competent upon the question of what a reasonable compensation under the circumstances would be; but unless, in some way, an agreement by the owner, express or implied, can be deduced from the circumstances under which the services are rendered, such custom or usage can, as binding him, have no force or effect whatsoever.

$\S 29$. Illustration of Rule.-A rather famous case in which this doctrine is enunciated and in which Mr. Melville W. Fuller, afterward Chief Justice of the United States, appeared as counsel for the plaintiff, was decided by the Supreme Court of the United States in October, I880. ${ }^{14}$ In that case, the County of Cooke and the City of Chicago, proposing to erect a building to combine a new court-house and city-hall, to be used and paid for respectively by the county and by the city, offered a premium for plans. The plaintiff furnished a plan accordingly and received the compensation promised. No additional contract between the parties was entered into. The city and county each adopted a resolution formally selecting the plan of the plaintiff, subject to such modifications as might thereafter be determined upon in the event that the plaintiff's estimate of the cost of construction should be verified. The plaintiff testified that thereafter he had verified the cost of the construction in the customary and usual way, and produced his plans and offered to prove their value and the time employed and the

14 Tilley v. County of Cooke, 103 U. S. 155. 
expense incurred in the preparation of them. This evidence the Court excluded. The plaintiff further offered to prove that, by the usage and custom of architects, in the absence of a special contract, the superintendence of the construction of a building should be given to the architect whose plans were adopted. The Court likewise refused to allow him to submit evidence on this point. He then offered to prove that in accordance with the custom and usage of architects, in cases where prizes for plans submitted as his had been were offered, the plans were the property of the successful competitors and belonged to them, and if they were subsequently adopted as the plans in accordance with which the building should be constructed, were always paid for, independently of the special prize itself. This evidence likewise was excluded, as was also his evidence offered to establish the value of services in verifying the cost of the proposed building, according to his plans. The Court below directed thereupon a verdict for the defendants and the case came before the Supreme Court by writ of error from that judgment. It did not appear that the plans of the plaintiff were used by either one of the defendants or that the building in connection with which they were prepared was ever erected. In substance, the plaintiff's claim was that, by virtue of the adoption of the resolution by the city council and county board, the city and the council were bound, without any further act on the part of the plaintiff, or further assent on his part, to 
proceed and erect the building in accordance with his plans and the estimated cost. It did not appear that the services of the plaintiff, in verifying the cost of the proposed building in accordance with his plans, were rendered at the instance or request of the defendants or either of them, and hence a statement of facts was not shown as a result of which the law would imply a contract to pay for these services. The Supreme Court held that:-

"In this case, there being only an expression of purpose by one party to erect a building according to plans antecedently made by another and no obligation entered into by the other party, and no plans used or building erected there was no contract between the parties either express or implied. . . . Proof of usage can only be received to show the intention or understanding of the parties in the absence of a special agreement or to explain the terms of a written contract .... ${ }^{15}$

"In all cases where evidence of usage is received, the rule must be taken with this qualification, that the evidence be not repugnant to or inconsistent with the contract .... ${ }^{16}$

"The inference from these principles is inevitable, that, unless some contract is shown, evidence of usage or custom is immaterial.

"The offer of the plaintiff to prove certain facts having been rejected, he must be presumed to be able to prove what he offered to prove. We must, therefore, assume

15 Citing, Hutchinson v. Bing. 465, 474; Clarke v. RoyTatham, Law Rep. 8 C. P. stone, r3 M. \& W. 752; Yeats 482 ; Field v. Lelean, 30 L. J. v. Pim, Holt N. P. 95; TrueEx. I68; Baywater v. Richard- man v. Loder, II A. and E. son, I Ad. \& E. 508; Robinson v. U. S., 13 Wall 363 .

${ }^{10} C$ iting, Holding v. Pigott, 7 589; Bliven v. New England Screw Co., 23 How. 420. 
that the custom which he offered to prove did, in fact, exist. But what was that custom? Clearly, that if the building was erected according to the successful plans, the architect was entitled to pay therefor. That was such an acceptance and adoption of his plans as would give him the right to compensation therefor, and the right to superintend the erection of the building and receive the usual remuneration. The custom certainly did not bind the party who offered prizes for plans, after having paid the prizes, to pay also for plans that he never used, and for superintendence of a building that he never erected, merely because he had selected a particular plan and announced his purpose to build in accordance with it. If such were the custom and usage of architects in Chicago, it was an absurd and unreasonable custom, and therefore not binding . . . ${ }^{17}$

"If the plaintiff had offered to show that after the passage of the resolution by which his plan was accepted, the defendants had erected their building according to his plans, then the evidence of the custom would have been pertinent. But he made no such offer, and it is to be presumed no such fact existed. The evidence of this custom was, therefore, properly excluded."

It is quite natural that variations of the ordinary problems in regard to compensation should arise in the practice of every architect, dependent on the special circumstances of each case. It is impossible to anticipate the exact state of facts which may in a special case be presented, but, whatever the situation may be, it will, in the vast majority of cases, be found to be governed by one or another of the broad general rules determining the right of the architect to payment for his services and prescribing the circumstances under ${ }^{17}$ Citing, United States v. Buchanan, 8 How. 83. 
which that payment can properly be demanded. In every case the broad underlying principles will be found to be that, where a definite agreement has been made, a recovery can be had in accordance with it if the architect has performed his part of the agreement, and if no definite agreement has been made, a recovery can be had for the reasonable value of the plans providing the architect is not in default and that nothing has been said or done by the owner, or by the architect, which introduces into the situation a new or additional element, such as the submission or acceptance of the plans on approval, or on the understanding that the work covered by them shall not cost more than a certain sum specified.

$\S 30$. Competitions. - It has been already noted that where plans are submitted in competition on the understanding that payment is to be made only to the successful competitors, those who are unsuccessful can have no cause of action for their services; and also, that where they are submitted in competition, as in the Tilly case Supra, wherein the plans for the city hall and county courthouse at Chicago were concerned, on the understanding merely that a prize is to be awarded to the successful architect, but no further contract appears between the parties, the extent of the architect's claim is the prize specified. This situation, however, will be varied if other conditions are introduced into the contest. If, for instance, the plans are submitted in competition on the understanding that those meeting with 
the approval of the committee are to be selected as the plans for the building and that the architect submitting the successful plans shall be appointed the architect and the superintendent of its construction, the architect whose plans are, under such conditions, accepted in the competition, has a definite right to be employed as the architect of the building and as superintendent of its construction, and has a right of action for a refusal to so employ him. ${ }^{18}$

§3. Proper Care and Skill Required.-Another question which may be of vital importance in determining the right of the architect to recover is the question whether, in his services rendered, he has exercised that proper care, skill and ability which, from his membership in his profession and his technical training, he is presumed to possess. If he allow the building to be erected in a manner which he knows or, from his training, should know to be improper, he cannot recover.

This rule would seem to apply where an architect, after a personal examination of the site suggested, has allowed a building to be erected thereon, when his training should have warned him that the site, on account of the poor composition of the soil or for other reasons, could not properly support the building or would be entirely unsuitable for the purposes proposed. ${ }^{18 a}$ The situation would be altered if the architect, after an examination

18 Walsh v. St. Louis Exposition, etc., Assn. 90 Mo. 459, affirming 16 Mo. App. 502. 18a Moneypenny v. Hartland, I C. \& P. (Carrington \& Payne) 352,2 C. \& P. 378. 
of the site, warned the owner that, in his opinion, it was not suitable and the owner, with full knowledge of the facts thus brought to his attention, directed him nevertheless to proceed. Under these conditions the owner would be assuming the risk personally, and the facts would present a very different case from that which is presented where the architect, knowing the defect, keeps silent and allows the building to proceed, or is so negligent that he fails to detect the defect at all.

$\S 32$. Modification of Contract.-It will sometimes happen that a contract specific in its terms as respects compensation will be modified by a new contract, in which no specific rate of compensation is agreed upon, and the new contract may, under such circumstances, take the place of the old. So, where a contract, definite in its terms as respects compensation, was entered into and was subsequently changed so as to make provision for plans of a more extensive character than those originally contemplated, but did not specify in its modified form any rate or amount of compensation, the architect was allowed to prove, on the theory of quantum meruit, the reasonable value of the plans prepared and of the additional services rendered by him. ${ }^{10}$ In this connection it must, however, be borne in mind that the law does not allow a written agreement to be varied by a parol agreement, and that an instrument, to be effective to modify another, must be executed

${ }^{10}$ Marcotte v. Beaupre, 15. Minn. I52. 
with the same formality as the instrument which it attempts to modify.

If the owner direct that changes be made in the plans or in the building, after the contract for the work has been awarded, or during the progress of the work, and the architect performs additional services in revising the plans or in superintending the extra work, made necessary by the changes directed by the owner, he may recover for the value of his services in changing the plans, ${ }^{20}$ and in superintending the work done; ${ }^{21}$ and it is not necessary, it seems, that he shall have given to the owner any notice that he expected additional compensation for such extra work. ${ }^{22}$

§33. Rescission of Contract by Owner-Preliminary Sketches.-Another situation of special interest to the architect as affecting his right to compensation, and one which arises with comparative frequency, is that which is presented when the owner, after the services agreed upon have been in part performed, rescinds the contract, or expresses his determination to proceed no further with the work. If his determination not to proceed with the building is based upon the fact that it has been agreed that the building shall not cost more than a certain sum, and that the estimates show that the limit will be exceeded, the architect, as has been seen, will, if this be

20 Johnson v. O'Neill et al., 148 N. W. (Mich. I914) 364, and see Baker v. Publishing Co. (Missouri 1903), 77 S. W. $5^{85}$.
21 Smith v. Bruyere, I52 S.

W. (Tex. I913), 8rз.

22 Smith v. Bruyere, $152 \mathrm{~S}$. W. $8 \mathrm{r} 3$, supra. 
true, have no remedy. But where some such element is not introduced, the architect will have the right to recover for the services which he has rendered, together with damages in an amount sufficient to justly compensate him for such injury as he has sustained by reason of the breach of contract on the part of the owner. Where, therefore, a client requests an architect to proceed and prepare sketches and the architect does so and delivers the sketches, and the client then notifies him that he has changed his mind and does not care to proceed, the client cannot, by such notification, escape his liability to make payment for the sketches prepared, as the notice serves only to prevent the preparation of additional plans.

$\S 34$. Illustration of General Rule.-This general rule has been clearly stated by the Appellate Division of the New York Supreme Court, which, reversing a judgment in the court below in favor of the owner, has held specifically that, under circumstances such as those stated, the architect has a definite right to recover for the preliminary sketches prepared. ${ }^{23}$ The Court said:

"The plaintiff did not claim to recover for completed plans and drawings, but only for preliminary sketches, and we are inclined to think that, on the evidence introduced, the jury would have been authorized to determine that the preliminary sketches, which were shown to the defendant at the time he claimed to have rescinded the contract, were completed, and that the only effect of his

${ }_{23}$ Pierce v Thurston, 40 A. D. (N. Y.) 577. 
countermand, at the time in question, was to prevent the plaintiff from going further and making complete plans and drawings. ...

"It is true that the defendant could at any time countermand his order for preliminary sketches (Clark $v$. Marsiglia, I Den. 317; Lord v. Thomas, 64 N. Y. I07, I09, IIO), and that the plaintiff could not recover for work done thereon after such countermand. But the evidence introduced on the trial was such as to authorize a finding by the jury that the plaintiff was employed by the defendant to make the preliminary drawings in question, and that he commenced at once and completed them. The defense interposed by the defendant, that he countermanded the order on the Monday following the day that it was given, was an affirmative one. A countermand did not defeat the plaintiff's recovery unless given before the work was completed. It was for the defendant to show an effectual countermand-one given before the drawings were finished. This he failed to do. The burden was upon the defendant, asserting as an affirmative defense to the plaintiff's claim a rescission of the contract under which the plaintiff claimed, to show that such rescission was made before the work which was shown by the plaintiff to have been done by him was finished."

$\S 35$. Cannot Compel Client to Complete.-In some instances where one who has employed others to perform certain services has notified them of his desire that no further services be performed prior to the completion of the services contracted for, attempts have been made to compel him to permit the work to be completed. It has been definitely determined, however, that, while a recovery may be had for the breach of the contract, the employer cannot be compelled to proceed with the completion of work which he has 
decided he does not care to undertake, and that the architect cannot persist in proceeding further under such conditions. ${ }^{24}$ Similarly, where a contractor has sought to compel the State to proceed with the erection of a public building, which he has been constructing under contract with the State, the specific performance of the contract on the part of the State will not be enforced, and a State statute, although involving a breach of the contract between the State and the contractor, will not, for this reason, be objectionable on the ground of unconstitutionality. ${ }^{25}$

$\S 36$. Measure of Damages on Refusal to Complete.-As to the measure of damages in a case where the defendant by requiring the plaintiff to stop work has violated his contract and thus became liable for the resultant damages to the plaintiff, such damages "would include a recompense for the labor done and materials used and such further sum in damages as might upon legal principles be assessed for the breach of the contract, but the plaintiff had no right by obstinately proceeding in the work to make the penalty upon the defendant greater than it would otherwise have been." 26

$\S 37$. Basis of Computation of Value of Services.-It remains to say a word in regard to the basis upon which the value of the architect's serv-

24 Clark v. Marsiglia, I Denio (N. Y.) 317; Lord v. 107. Thomas, 64 N. Y. 107.
25 Lord v. Thomas, 64 N. Y.

${ }^{26}$ Clark v. Marsiglia, I Denio (N. Y.) 317 . 
ices is to be determined. In the case of a definite contract, the terms thereof will be controlling and the question of what is the reasonable value of the services rendered will not arise; but where the recovery is sought upon the basis of quantum meruit, proof of what constitutes a reasonable valuation of the work done is requisite. Where it is agreed that the percentage representing the compensation of the architect is to be upon the "estimated cost," the provision is interpreted as referring to the reasonable cost of the building "erected in accordance with the plans and specifications, .... and not necessarily the amount of some actual estimate made by a builder, nor an estimate agreed upon by the parties, nor yet an estimate or bid accepted by the defendant." ${ }^{27}$ The architect may not prove a professional custom or usage which will entitle him to be paid a percentage based upon estimates which he has himself prepared. The determining element should be the time spent upon the work or such understanding, express or implied, as existed. ${ }^{28}$ If it be shown that the owner was fully cognizant of a custom whereby the percentage would be based upon the architect's own estimates, it seems that a modification of this rule might quite possibly be applied, ${ }^{29}$ although proof of the custom would not be allowed to vary the terms of a contract entirely specific and definite in its provisions.

\footnotetext{
${ }^{27}$ Lambert v. Sanford, 55 Conn. 437.

${ }^{29}$ Scott v. Maier, 56 Mich. 554, supra.
}

28. Scott v.Maier, 56 Mich. 554. 
By entering into such a contract, with a knowledge of the special customs at variance with it, the parties would be assumed to be deliberately basing their agreement on the conditions specified in the contract, and in no way upon the conditions prescribed by custom.

Under the rule of quantum meruit, where the contract is silent upon the subject of compensation, the architect, as has been seen, will be entitled to a reasonable compensation. ${ }^{30}$ As to what constitutes reasonable compensation, the decisions will vary in accordance with the circumstances, and any facts which bear upon the reasonableness of the charge will be competent evidence. So, a schedule of customary charges, or proof that the owner was aware of the ordinary charges of the architect, or that the architect had shown to him, without objection on his part, a scale of his own rates of charges, or proof of the charges made for similar work by the profession in the locality where the contract is entered into and the work performed, are all competent as elements of proof on the question of what charge is reasonable. In New York it has been definitely determined that the charge schedule of the American Institute of Architects may be properly introduced as showing the customary legitimate rate of compensation allowable. ${ }^{31}$ The New York courts have likewise decided that the client is

30 Dull v. Bramhall, 49 Ill. 364; Knight v. Norris, I3 Minn. 473; Mulligan v. Mulligan, I8 La. Ann. 20.
31 Gilman v. Stevens, 54 How. Pr. (N. Y.) 197. 
chargeable with a knowledge of the standard and regular rates of the architect's fees, where it appears that the client has been charged the same rates by the same architect on several previous occasions. $^{32}$

It may be that the architect, by some act on his part, may so change the situation as to render incompetent proof which might otherwise be competent on the point of reasonable compensation. Thus in a case decided by the Supreme Court of the United States, where the plaintiff and his partner, architects, had accepted salaries of $\$ 5,000$ and $\$ 3,000$, respectively, the one as architect and the other as chief draftsman, for preliminary work done by them, and to which they devoted their entire time, in connection with the Congressional Library, and then subsequently, upon the building of the library, claimed to be entitled to compensation for this later work on the basis of quantum meruit, the Court held that the compensation for such later work should not be determined on the basis of the schedule of charges of the American Institute, for the reason that the architects, in accepting the salaries specified, had themselves furnished a basis upon which the amount of the reasonable value of their services should be computed, and allowed them \$48,ooo for six years' services. ${ }^{33}$

$\S 38$. General Suggestions.-In dealing with this whole general subject of his compensation,

32 Gilman v. Stevens, 54 How. Pr. N. Y. I97, supra.
${ }^{33}$ Smithmeyer v. U. S., 147 U. S. 342 . 
the architect, if he would properly protect himself, should exercise the same care to insure that matters be definitely understood and provided for which, it has been seen, it is so desirable that he should exercise in the matter of his powers and liabilities as agent. $\mathrm{He}$ should carefully avoid any statements or acts from which may be inferred an agreement that the building shall be erected for a definite fixed maximum cost, and should likewise avoid, where practicable, the submission of any estimate of its probable cost of construction. Where such an estimate is necessary he will do well to couple with it a direct statement to the effect that it is impossible to tell the exact amount which the building will cost, and that it must be understood that his right to his compensation must in no wise be affected by any variation between the estimated amount and the amount of the actual building cost. Especially should he be wary in accepting and undertaking work where the client stipulates, as a condition precedent to payment for services rendered, that the sketches must be satisfactory, for agreement by the architect to such a condition will render him powerless to enforce payment for his services, in the event that the sketches are not approved-unless, perhaps, he can in some way show that the client has not acted or intended to act in good faith in making the condition, and has never intended to accept the sketches under any circumstances.

Where a client specifies that a certain style of 
architecture shall be followed, care should be taken that the style which he has in mind is clearly understood. If, for instance, he states that he wishes the work done in accordance with Gothic style, it may well be that his idea of "Gothic" is entirely different from the true interpretation of that word as used in this connection, and while, under these circumstances, the architect, if he did the work in Gothic style, and thus complied with the terms of his contract, would be able to sustain a recovery, yet his right to do so might easily be endangered if it were shown that, from the conversation with the client, or other circumstances, he should have known or should have suspected that the meaning of the word Gothic, as interpreted by the client, was not the same as the ordinary meaning and interpretation of that term as used in the architectural profession.

Again, in the preparation of the plans, many difficult situations and probable losses will be avoided if care be taken to advise the client of the cost of the extra work which changes ordered by him will entail. Where the client makes such changes, thereby increasing the cost of the building, his act in itself would, where it has been agreed that the building shall not cost more than a definite sum, tend to relieve the architect of a part, at least, of the liability imposed by that condition, but the latter's position will be infinitely stronger if he be in a position to state that he has warned the owner that the changes contemplated will necessitate an increase in price over the 
amount contemplated, and that the client has made the changes notwithstanding.

So, too, the client should be warned that there may well be a variance between the working drawings as finally prepared and the preliminary sketches submitted. If there be a substantial variance in this respect, that is, to such an extent that the plans call for a building entirely or radically different from the scheme shown by the sketches, or a building so varied in treatment or in plan that there is a real and substantial difference between the preliminary suggestions upon which the owner acted, and the plans as finally submitted to him, the owner may well claim that, having ordered plans to be prepared for a building to accord with the sketches submitted, he cannot be called upon to make payment for plans which call for a building of a distinctly different type. The mere fact, however, that the plans show some slight modification in unimportant details of the original scheme as shown by the sketches, will not, especially where the client has been warned, as suggested, that some variance will probably be inevitable, preclude a recovery by the architect for the full amount of his services in the preparation of the plans and drawings.

The same rules upon which is based the right of the architect to compensation for preliminary sketches and drawings will naturally apply to his right to compensation for the preparation of 
specifications and the superintendence of the building; that is to say that where the amount or rate of compensation is definitely specified in the contract, the terms of the latter will be controlling, and where the amount or rate is not so specified, the recovery by the architect will be upon the theory of quantum meruit, viz., the reasonable value of the work performed. In determining this reasonable value, evidence of custom, of the schedule of charges of the American Institute, or of other similar facts and circumstances will be competent, just as they are competent in the case of proof of the reasonable value of services performed in the preparation of preliminary sketches or plans. As the architect owes the utmost good faith to the owner in his dealings with him, so the owner must be entirely honest and above-board in his dealings with the architect, and for any conspiracy between the owner and the builder, the result or purpose of which is to injure the architect, the latter can hold the owner liable in damages. So, if it can be shown that an owner's refusal to comply with the contract, and proceed with the building, is pursuant to or the result of an improper agreement between the owner and the builder, having for its object the prevention of a recovery by the architect of the amount which he would be entitled to recover if the contract were completed, proof of such facts will be competent as tending to show malice or improper conduct on the part of the owner, thus 
increasing proportionately the damages recoverable from him by the architect for the breach of contract in question.

In a word, the more definitely all conditions touching the right of the architect to compensation are determined upon and made clear in advance-the more care that is exercised by the architect in determining what is the owner's understanding on all points, and that his understanding of the character and expense of contemplated changes or extra work done is clear-the more surely will misunderstandings and controversies and losses, on the part of each, be avoided, and the less opportunity will there be presented for the entry into the situation of conditions adversely affecting the right of the architect to proper compensation for the time and thought which he has expended, the expenses which he has incurred, and the services which he has rendered. 


\section{CHAPTER IV}

\section{DUTIES AND LIABILITIES OF THE ARCHITECT}

$\S 39$. In General.-In holding himself out to the public as a practicing member of the architectural profession the architect assumes the same responsibility, for reasonable skill and care in the public service, as that which rests upon a lawyer or a physician; ${ }^{1}$ and under the rule that one who publicly professes to possess skill in a given art thereby represents or intimates to all the world that he possesses the ability and skill requisite to practice that art, ${ }^{2}$ he who holds himself out to the public as an architect is presumed to possess the skill and ability requisite and necessary for the proper practice of the architectural profession.

The broad general duty of an architect to act in the utmost good faith in his employer's interest, and to do no act which may hinder him in giving that disinterested and honest service which his relationship with his client demands, has already been referred to. It remains to consider the more specific duties and liabilities of the architect, such as the preparation of plans and specifi-

${ }^{1}$ Coombs v. Beede, $89 \mathrm{Me}$. B. (N. S.) 236 , and see opinI87. ion of Jervis C. J. in Jenkins

${ }^{2}$ Harmer v. Cornelius, 5 C. v. Betham, 15 C. B., at p. 189. 
cations, the superintendence of the work and the issuance of certificates.

It should be noted, preliminarily, that an architect is, in general, liable for want of care or skill in the execution of his work to his employer only, and is not liable to third persons for damages resulting from accidents or injuries sustained after the completion of the work. ${ }^{3}$ The legal distinction, in this connection, between a tort to a third person, predicated upon the omission of some act or obligation to the public as such, and a tort predicated upon a direct injury to a specific third person, has been well stated to be that, in the event that one "omits to do some duty or obligation which he owes to his employer and which is a tort to a third person, he is not liable, but when he commits a tort which is an injury to anyone, there is no reason why he should not be liable for his acts as anyone else." The writer so stating the rule cites as examples thereof a case, on the one hand, of a superintendent of a plantation who neglected and refused to keep open a drain on his employer's land, thereby flooding the lands of the neighbors and damaging them, and who was held not to be liable to the neighbors; and, on the other hand, the case of an architect in charge, who adopted a bad plan of construction, as the result of which, and by reason of his negligence, misfeasance and failure to observe the skill and care imposed by law, a disaster resulted, and who was

${ }^{3}$ Mayor v. Cunliff, 2 N. Y. 165; Wait, Eng. \& Arch. Jurisprudence, $\$ 842$. 
held to be responsible in damages to the workmen injured, as well as to the contractor. ${ }^{4}$

$\S 40$. Plans and Specifications.-It has already been noted that, as a result of defects in his plans, an architect may be debarred from recovering his compensation for them and it is also true that for these defects he may in addition be liable in damages. ${ }^{5} \quad$ This liability, providing the defects upon which it is based would be patent to one skilled in the art though not apparent, perhaps, to one lacking such expert training, would not, it seems, be affected by the fact that the building had been accepted and the superintendence of it ratified. ${ }^{6}$

$\S 4 \mathrm{I}$. Mistakes.-Where there are mistakes in plans and specifications which increase the cost of the building and which proper skill and care would have obviated, the architect is, apparently, liable; ${ }^{7}$ and likewise it has been held to be a breach of the duty which he owes to his employer, if he allow a foundation to be so constructed that it is not deep enough, or not protected sufficiently otherwise, to prevent the cracking of a wall which it supports. ${ }^{8}$

$\S 42$. Negligence-Measure of Damages.-In an action to recover damages for the negligence of an architect in the preparation of plans, the

4 Wait, Eng. \& Arch. Jurisprudence, $\$ 842$, citing:Feltus v. Swan, 62 Miss. 415, and Lottman v. Barnett, 62 Mo. 159.

5 Shipman v. State, 43 Wis. 381; Niver v. Nash, 35 Pac.
Rep. (Wash. Sup. Ct. Dec. 1893), 380.

'Shipman v. State, 43 Wis. 381.

${ }^{7}$ Erskine v. Johnson, $23 \mathrm{Neb}$. 265 .

${ }^{8}$ Schreiner v. Miller, 67 Iowa 91 . 
measure of damages has been fixed at an amount equal to the difference between the value of the building, as actually designed and constructed, and the value as it would have been, if the building had been properly designed and constructed. ${ }^{9}$

$\S 43$. Limitation of Rule-Architect not Liable If Plans not Adhered To.-While the rule is clear that damages may be recovered which are the result of defective plans and specifications, yet it must not be supposed that such damages can be recovered if, in the erection of the building and without the fault of the architect, there has been a substantial variance from the plans and specifications as submitted by the architect. This is on the theory that an architect, in warranting the safety or proper construction of the building which he designs, warrants it on the assumption and understanding that all of the substantial conditions stated, shown, or included by him in the specifications, and which in his opinion may be necessary and essential to the proper construction of the building, shall be carried out and observed.

$\S 44$. Burden of Proof-Illustrations of Rule. -Where damage of this character is claimed, the burden is upon the plaintiff to prove a substantial compliance with the plans and specifications. The leading case on this point and a case in which the law is stated at some length and with great clearness was decided by the Court of Appeals of New York State in October, 1893. In that case,

${ }^{9}$ Larrimore v. Comanche County (Tex. Civ. Apps. Sep. 1895) 32 S. W. 367. 
an action was brought against the architects (a firm) to recover damages claimed to have resulted by reason of defective plans, specifications, and drawings, prepared by them for an opera house. The sole defect complained of was in regard to the plan of the proscenium arch which was in segmental form, thirty-six feet long with a rise of eight feet. It was built of brick and, upon the removal of the cradle supporting it, fell, necessitating its reconstruction. In the court below, the plaintiff recovered as damages, a sum equal to the cost of rebuilding it and the added cost of repairing the injury which its fall caused to the other parts of the building.

The plaintiff, an assignee, based his claim in particular upon the failure of the defendants to make provision in the plans and drawings for a blind arch over the segmental arch, on the theory that if such had been shown and provided for, it would have been constructed and no damage would have resulted. The plaintiff gave evidence in the court below which tended to show that the fall of the arch might have been due to the fact that it was too flat and that the spring necessary for self-support in an arch of the width of the one in question, could not be given by a rise of eight feet therein. The plaintiff was also allowed to give evidence that the arch was so planned and constructed that its thrust fell without, instead of within, the abutments upon which it rested, and that its fall may have been due to this fact also. The plan of the arch required that 
stone skew backs be put in at each heel, at the points where the arch met the abutments. It appeared that the purpose of these skew backs was to furnish a firm foundation for the arch and to distribute its thrust over a larger area of the abutments. One of the defendants, a man of large experience, testified to the preparation of plans for and the building of many theaters and opera houses and the placing in many of them of segmental arches having no greater rise than the one in question, without experiencing any difficulties, and he also testified that he always made provision in such plans for stone skew backs and considered them elements of vital importance to the support of the structure. It appeared that in building the arch in question these skew backs were omitted and that the responsibility for their omission rested with plaintiff's superintendent. Experts testified that skew backs of stone were necessary to the proper construction of the arch, bearing out the testimony of defendant on this point. The Court below submitted the question to the jury on the finding that the arch fell on account of the omission of the stone skew backs, holding that there was sufficient evidence to support a finding to that effect and instructing the jury that if they found this to be the case, the plaintiff could not recover. The jury evidently did not so find for they gave judgment for the plaintiff. Judge Maynard of the Court of Appeals in reviewing this decision said: 
"But we think it was error to submit this question to the decision of the jury. When it was conceded that the plaintiff's assignor had not followed the plans in this respect, and it appeared that the failure to put in the stone skew backs may have caused the loss, which the plaintiff is seeking to impose upon the defendants, they were entitled to a ruling as a matter of law, that the plaintiff could not recover, and the complaint should have been dismissed. He had failed to establish a performance of the conditons precedent, which was essential to the support of his cause of action. One of the principal allegations of the complaint had been left unproven. The action is ex contractu, and the defendants cannot be made liable upon a contract which they never assented to. There is no principle upon which a case of this kind can be excepted from the rule, so firmly established, that every stipulation which the parties have inserted in a contract by way of conditions to be performed is to be deemed material...10 The plaintiff's assignor was contracting for the exercise of the technical knowledge and skill of the defendants, and it was upon the infallibility of their own judgment that the defendants relied when they made their guaranty that if the arch was constructed in accordance with their directions it would stand. They regarded a stone skew back of vital importance for its security and stability, and their promise to make good any loss which might occur if it fell, was upon condition that this method of construction was adopted, and we are not permitted to say that they would have entered into the agreement had they known that these essential supports were to be omitted.

"It is not necessary to hold that a literal performance

${ }^{10}$ Citing, Dauchey v. Drake, 85 N. Y. 407 ; Hill v. Blake, 97 id. 216; Tobias v.Lissberger, I05 id. 404; Bank of Montreal v. Recknagel, I09 id. 482; Clark v. Fry, I21 id. 470 ; Norrington v. Wright, 115 U. S. I88; Glaholm v. Hays, 2 M. \& G. 265 . 
of the condition was required. A variance, confessedly immaterial, or a departure from the plans in a separate and independent part of the building, having no structural relation to the defective member, would present a different case for our consideration. But where the variance is not disputed, and involves the integrity of the mode of construction of the affected part, and is so far material that it may have been the direct cause of the injury for which the owner seeks to hold the architect responsible, it must be held, we think, that the plaintiff has failed to establish the cause of action upon which he relies." 11

In another State the Court seems to have gone so far as to substantially assume, as a matter of legal inference, that the architect is negligent where the walls of a building crack on account of a defective foundation; ${ }^{12}$ but the New York doctrine would seem certainly to be the more equitable, safeguarding as it does the architect against claims for damage occasioned through no fault of his own, considering fully each case in the light of the special facts developed, and keeping more clear the distinction between the architect and the owner and the particular duties of each, in determining whether the damage is or is not traceable to a lack of skill or neglect on the part of the architect.

$\S 45$. Repairs and Superintendence.-Where, on account of defects or of some oversight on the part of the architect it is necessary that repairs be made, the claimant cannot make these repairs

11 Lake v. McElfatrick, 139 N. Y. 349 reversing $46 \mathrm{~N}$. Y.

12 Schreiner v. Miller, 67 St. Rep. 437, 19 N. Y. Supp. 494. 
at an unnecessary expense, or in an unnecessarily extravagant form, and recover as damages the amount of his disbursements in so doing. He must confine his claim to such sum as will represent the cost of effecting the repairs as economically as it is possible to effect them, consistent with proper workmanship and construction. It must always be borne in mind, also, that the architect does not guarantee satisfaction, and that in the absence of special circumstances or agreements, his duty is fulfilled when he has prepared the plans and carried out the provisions of his contract with reasonable skill, diligence and care.

\$ 46. Reasonable Care and Diligence Required -Illustrations of Rule.-The rule requiring the exercise of reasonable care and diligence on the part of the architect in the preparation of plans ${ }^{\mathbf{1 3}}$ is equally applicable to his position as superintendent. ${ }^{14}$ If such reasonable care and diligence be not observed, the architect will be liable to the owner for any damage which may result to the latter by reason of such neglect. ${ }^{15}$

It is not necessary that the architect give to the matter of superintendence more than reasonable and ordinary care, or exercise therein more than reasonable and ordinary diligence; nor do ordi-

13 Johnson v. Wanamaker, riman v. Fowler, 37 N. J. L. $17 \mathrm{~Pa}$. Sup. Ct. 301 .

${ }^{14}$ Straus v. Buchman et al., 96 N. Y. App. Div. 270; Gilman v. Stevens, 54 How. Pr. (N. Y. Super. Ct.) 197; Mer89 ; Coombs v. Beede, 89 Me. 187.

15 Merriman v. Fowler, 37 N. J. L. 89 ; Lottman v. Barnett, 62 Missouri 59 . 
nary care and diligence require that he superintend the work so closely as to follow every movement of every workman, and be able to discover all variations of every character from the contract provisions and all defects in execution, including such defects as can only be detected by the exercise on his part of extraordinary diligence. $^{16}$

To avoid the charge of negligence it is not essential that the architect prove the exercise of "the utmost skill such as only a few members of any profession attain to," but he must show what "other architects will generally consider to be a reasonable degree of professional knowledge and skill." 17

In this connection it should be noted that what might perhaps be a reasonable degree of skill in one locality, would not be in another. For instance, the degree of attention which an architect may properly give to country work, unhampered by city ordinances, would not be at all sufficient for work done in a large city, under local rules, regulations and building ordinances, which must be given strict attention by the architect, if he is to secure the rights of his client and the proper conduct of the work.

It may happen that the superintendence of a

10 Petersen v. Rawson, 34 N. Y. 370 , reversing 2 Boswell, N. Y. 234; Hubert v. Aitken, I5 Daly, N. Y. 237; Stewart v. Boehme, 53 Ill. App.
Court 463; Vigeant v. Scully, 20 Ill. App. Court 437.

17 Clark on Architecture, p. 28. 
building will be in the hands of an architect who did not prepare, and had no part in the preparation of, the plans, but the fact that the plans were made by another architect before the superintending architect took charge, will not relieve the latter of responsibility for defects in the building as erected under his supervision; ${ }^{18}$ and while the architect is not held to the necessity of preventing every slightest shade of variation from the plans and specifications, he must, nevertheless, bestow such care and attention as may be necessary to detect variations or faults which are of such a character as to be of real importance and materiality. ${ }^{19}$

The architect and the builder may be jointly and severally liable to the owner in the case of neglect attributable to them jointly. In New Jersey this doctrine has been applied to the extent of holding that, where a joint neglect by the builder and architect is proven, a suit may be maintained against the architect alone, and that the fact that the owner has, at the same time, held back from the contractor a part of the money due to the latter, upon the ground that the contractor is equally liable with the architect, will be no bar to the action against the architect himself. ${ }^{20}$ So where a floor has sunk on account of the insufficiency of timber used, the architect and the builder ${ }^{18}$ Scott v. Christ's Church Y. 370; Wait, Eng. \& Arch. Cathedral, I L. C. L. J. 63.

10 Petersen v. Rawson, 34 N. Jur. § 839, p. 759 .

${ }^{20}$ Newman v. Fowler, $37 \mathrm{~N}$. J. L. 89 . 
have been held jointly and severally liable for the resultant damages. ${ }^{21}$

In New York, in a somewhat similar case, decided in July, I904, where it was proven that the architect visited the building as superintendent on an average, substantially, of at least once a day, but, between his visits, important floor timbers were placed, and in such a manner as to be in direct violation of law, and this occurred after the owner had taken possession, and necessitated the making of important repairs, the Court, stating the rule that reasonable care and diligence must be exercised by the architect in the superintendence of the work, and that the question whether or not the architect is negligent is a question of fact to be passed upon by the jury, held that:

"It was the duty of the defendants under their contract with plaintiff, not only to see that the beams were properly placed, but especially to see that the placing of them conformed to the requirements of the statute. This they failed to do. . . . The evidence ... established the fact that numerous and extensive repairs were made necessary by reason of the defective work, the cost of which and other work necessary for putting the building in the condition in which it would have been had the defendants performed their contract, would have justified a larger verdict. The plaintiff was entitled to recover a sum which would leave him as well off as he would have been had the defendants fully performed their contract." ${ }^{22}$

The duty of the architect in regard to the ma-

21 David v. McDonald, 8 L. C. (Lower Canada) Jurist 44, I4 L. C. Rep. 3I.
22 Straus v. Buchman et al., 96 N. Y. App. Div. 270, at 273274, citing 8 Am. \& Eng. Enc. of Law, 2 d ed. 634 . 
terial used applies, of course, to the character of the material itself, as well as to the manner in which it is used in the work of construction, and the measure of damages for neglect in permitting the use of inferior material or labor is a sum equal to that which will be required to properly repair and make a good job of the work in question. ${ }^{23}$ Where by the contract the superintendent, as a part of his duties, is required to furnish monthly estimates of the work done, this provision is not necessarily, it seems, to be taken as meaning that "he must furnish correct and accurate estimates," the monthly estimates referred to being in their nature and of necessity, mere approximations. ${ }^{24}$

On the broad general question of the degree of care and diligence required of an architect in the performance of his duties as superintendent and supervisor of construction, one of the leading cases, if not the leading case, in the American courts, is a case which came before the Court of Common Pleas of the City and County of New York, in 1889. Following the first decision in this case a re-argument was held and the judgment affirmed and later the same judgment was again affirmed in all ways by the Court of Appeals. The plaintiffs were the architects who prepared the plans for, and supervised the construction of, the building. After the completion of the building it was discovered that the flues, which con-

${ }^{23}$ Gilman v. Stevens, 54 381, and see 1 Redfield on How. Pr. (N. Y.) 197. R. R., 6th ed. § II6.

24 Shipman v. State, 43 Wis. 
nected with the boiler flues, were not sufficiently large to meet the purposes for which they had been designed. The defendant claimed that no recovery could be had for the reason that the contract was entire and that the plaintiffs had not performed their contract, in that they were negligent in the designing and construction of the flues. The flues were not omitted from the plans, but were set down with the same detail as were the other parts of the building. The Court held that it could not be said that the plaintiffs had not entirely performed their contract as to the plans; that they had performed it completely, but that they had performed it negligently, and that while the defendant was entitled to deduct the amount of the damage caused by the faulty design of the chimney from the amount due under the contract, for the drawing of the plans and the superintending of the construction of the house, nevertheless, the defect in construction could not be urged to defeat all recovery on the contract. Speaking of the degree of diligence and care required of the architects in their superintending capacity, the Court gave the following very clear statement of the law by which the duties of the architect, in this respect, are governed:

"The learned counsel would not claim that an architect is bound to spend all his time at a building which is going up under his professional care, so that no fraud or negligence can be committed by any of the contractors. The counsel would not contend that the architect is an insurer of the perfection of the mason work, the 
carpenter work, the plumbing, etc. $\mathrm{He}$ is bound only to exercise reasonable care and to use reasonable powers of observation and detection, in the supervision of the structure. When, therefore, it appears that the architect has made frequent visits to the building, and in a general way has performed the duties called for by the custom of his profession, the mere fact, for instance, that inferior brick have been used in places, does not establish, as a matter of law, that he has not entirely performed his contract. He might have directed at one of his visits that portions of the plumbing work be packed in wool; upon his next return to the building the pipes in question might have been covered with brick in the progress of the building. If he had inquired whether the wool-packing had been attended to, and had received an affirmative answer from the plumber and the bricklayer, I am of opinion that his duty as an architect, in the matter of the required protection of said pipes from the weather, would have been ended. Yet, under these very circumstances, the packing might have been intentionally or carelessly omitted in fraud upon both architect and owner, and could it still be claimed that the architect had not fully performed his work? The learned counsel for appellant is, in effect, asking us to hold that the defects of the character above named establish, as matter of law, that plaintiffs have not completely performed their agreement. An architect is no more a mere overseer or foreman or watchman than he is a guarantor of a flawless building, and the only question that can arise in a case where general performance of duty is shown is whether, considering all the circumstances and peculiar facts involved, he has or has not been guilty of negligence. This is a question of fact, and not of law. Upon consideration I am more fully convinced of the correctness of our conclusions reached after the former argument." 25

${ }^{25}$ Hubert v. Aitken, 5 N. Y. Supp. 839, opinion Larramore, C. J. 
Another leading case, also in New York, and decided by the Court of Appeals of that State, is illustrative of the same doctrine. In this second case, through an error, the front parlor windows of a building were so constructed so as to be two and three quarter $(23 / 4)$ inches higher than was shown by the plans, and the same distance higher from the floor than the back parlor windows. It appeared that the plaintiff-the architect-had been diligent in his attention to the details of superintendence, and that the defect was caused by the masons not having accurately followed and conformed to the plans and specifications. The Court held, one justice dissenting, that the defects in question were not chargeable to the plaintiff, and that they afforded the defendant no justification for withholding from the architect payment of the amount agreed upon as the latter's compensation for his services. The Court said:

"The plaintiff agreed to make 'the plans, sections, elevations, specifications, and to superintend the progress' of the building to be erected. It was not his duty to do the work. The agreement between the defendant and his masons provides that the masons 'shall well and sufficiently erect and finish' the building in question 'agreeably to drawings and specifications made by Frederick Petersen.' It was not the duty of the plaintiff to 'lay out' the work, as it is technically termed. This, it was expressly provided, should be done by the mason, who agrees 'to lay out his work himself.'

840 , affirming 2 N. Y. Supp. 7II; 15 Daly (N. Y.) 237 (including both original opinion

and affirming opinion of Larramore, C. J.) ; judgment affirmed without opinion, 123 N. Y. 655. 
"The plaintiff was bound to furnish the plans, specifications and elevations, and the mason was bound to lay out the work. In other but perhaps not plainer words, the plaintiff was bound to put down, and to show on paper, how every part was to be built, and the mason was to stake it out, measure his lumber, and make actual measurements on the ground and in the erection for such building. I do not think it was the duty of the plaintiff to measure the joists or timbers of which the different stories were to be constructed, and to determine by actual measurement that the ceiling of the first story had an elevation of thirteen feet, and the second had an elevation of eleven feet, or to measure the thickness and depths of the brick or stone walls. . . The first story windows in the front parlor were to be sixteen inches from the floor, and the windows themselves were probably ten or eleven feet in height. The plaintiff came from day to day to superintend the progress of the work, and while thus superintending, was he bound to have ascertained that the window sills in the front parlor were two and three-quarter inches higher from the floor, than was authorized by the plan? To an inexperienced eye the difference would not have been perceptible; but should the knowledge and skill of a good architect at once have detected it? The testimony is not satisfactory to establish the affirmative of this proposition. Wm. Thomas, an archiect, says, 'that he does not consider that the building has been properly superintended. If it had been, the mistake would have been found out when the first story beams were on. Comparing the second story beams, I should have found it out.' Mr. Windham, an architect, thinks the difference in height between the parlor windows in front and in rear, ought to have been discovered as soon as they began to lay the brown stone in front. Mr. Ritch, on the other hand, also an architect, says, 'that it is impossible to say when the error should have been discovered. It might have passed the observa- 
tion of the architect, till the building was completed. It is an error likely to pass any one's observation. It would most likely pass his notice until the cornices were put up.' These were the only architects who testified on this point. It was proved by various witnesses that the plaintiff was diligent in his attendance upon the building. The respectable and intelligent referee who had the witnesses personally before him, and was able to form a better opinion of their intelligence and integrity than one who did not see them, must have held that the plaintiff was not bound to have discovered this defect. Mr. Traphagen testified that he told the plaintiff the balcony was too high, and that he said it was all right. He was one of the contractors for the mason work, and it was apparently a question whether the fault was on his part or that of the plaintiff. The referee did not rely on his evidence. He found that the plaintiff had bestowed as much personal attention upon the building as was necessary, and that the variations mentioned were not caused by carelessness, negligence or inattention on his part. I do not find it necessary to differ with him." 28

It will sometimes happen that a change of more or less importance which has been requested by the owner, as for instance a change in the location of gas or electric outlets, may be overlooked by the architect. If the change be spoken of and brought to the attention of the architect before the plans and specifications are approved and then these plans and specifications, not including the change, are examined and approved by the owner, the latter, by his approval, following his examination of them, may estop himself from later claiming damages from the architect for the latter's

${ }^{26}$ Petersen v. Rawson, 34 N. Y. 370, at pages 372,373 and 374 . 
failure to provide the change required. This rule would not be applicable to a situation where the owner, to the knowledge of the architect, signed the contract and approved the plans and specifications without reading or examining them, and in reliance on the assurance of the architect that everything necessary and desired had been included and provided for. Where the change is requested after the plans and specifications have been approved and the contract signed, it is the duty of the architect to see that the proper instructions of his client are carried out, the work under these circumstances being in the nature of an extra; and for negligence or improper skill or lack of diligence in carrying out the directions of the owner, the architect will be liable within the ordinary rule requiring the exercise by him of reasonable skill and diligence.

The architect cannot escape liability for damage resulting from steps taken subject to his direction or on his advice and approval, on the mere plea that he was not present when the damage resulted; and where a wall fell as a result of a jackscrew worked under the supervision of one employed by the owner on the advice of the architect, and subject to the latter's direction, and it was shown that the architect approved the use of the jackscrew, he was held liable in damages for the death of a workman as a result of the falling of the wall, despite the fact that the architect was not present at the time the accident occurred. ${ }^{27}$

${ }^{27}$ Lottman v. Barnett, 62 Mo. 159. 
$\S 47$. Negligence a Question of Fact.-The question whether there has or has not been negligence or want of skill in a given case is a question of fact and not of law; ${ }^{28}$ but the matter of negligence, while a question of fact, and, consequently, a question for the jury, should not be left to the latter in such a way as to refer to them the question of what it is proper or improper in the broad sense for the architect to do, entirely unrestrained by the evidence or special circumstances of the case. Where, on the facts, it appears that the architect has used reasonable diligence, care, and skill, it is improper to leave it to the jury to decide whether he has properly performed his duties. ${ }^{29}$

$\S 48$. Burden of Proof.-The burden of proof in a proceeding to recover damages for negligence or want of skill on the part of the architect is upon him who seeks to establish it. ${ }^{30}$ On the other hand, it is no answer to a charge of negligence to plead reliance on the statements of others. ${ }^{31}$

$\S 49$. Architect as Arbitrator.-In many cases the architect will, under the terms of his contract, be called upon to act as referee or arbitrator in the

28 Straus v. Buchman, 96 N. Y. App. Div. 270; Hubert v. Aitken, 15 Daly (N. Y.) 237 ; I9 N. Y. St. Rep. 9I4; 2 N. Y. Supp. 7II, affirmed (on re-argument) 5 N. Y. Supp. 839, I5 Daly (N. Y.) 24I, affirmed by Court of Appeals, 123 N. Y. 655.

29 Vigeant v. Scully, 20 IIl.

Apps. 437.
30 Gilman v. Stevens, 54 How. Pr. (N. Y. Supr. Ct.) I97 at 207.

31 Moneypenny v. Hartland I C. \& P. (Carrington \& Payne) 352 ; 2 C. \& P. 378 ; Hubert v. Aitken, I5 Daly (N. Y.) 237 , judg. aff'd, 123 N. Y. 655 , supra. 
determination of some question arising during the progress of the work. In such an event a new rule of law is to be considered, namely, that a judicial officer is not liable in matters connected with the exercise of his judicial duties, provided, and so long as, he exercises these duties honestly. This rule includes not only judges of courts, but all officers in general who are necessarily called upon to exercise duties of a judicial or quasi-judicial nature or duties to be performed in accordance with the dictates of their judgment. ${ }^{32}$ Where, therefore, an architect "undertakes to give a decision as to any matter, though he may not be an arbitrator in a strict sense of the word, and is not bound to exercise all the judicial functions an arbitrator would have to exercise, nevertheless, he is not liable to an action for want of skill." 33

$\S 50$. Certificates.-Many of the more important questions, of interest to the architect in the matter of the issuance of certificates, arise as between him and the builder, or in actions by the builder against the owner to recover the contract price. These questions are considered elsewhere. ${ }^{34}$

The architect is, however, under certain definite duties and liabilities to the owner with respect to the issuance of certificates and, in issuing them,

32 Jones v. Brown, 54 Iowa 74 ; Pappa v. Rose, L. R. 7 C. P. 32 ; I Eng. Rep. 87, aff'd L. R. 7 C. P. 525, 3 Eng. Rep. 375; Wait, Eng. \& Arch. Jur. $\$ 844$; Mechem on Public Officers, $\$ \S 638-639$.
33 Wait, Eng. \& Arch. Jur., § 846; Pappa v. Rose, L. R. 7 C. P. 32, 525, supra.

34 See $\$ \$$ I I, 55, 66, 95, 97, 98, 99, II 4. 
he must exercise that same reasonable care and diligence which is required of him in the preparation of his plans and in the supervision of the work of construction. This rule has been applied to circumstances where the contractor failed and, as a result of his failure, the owner was compelled to complete the work at an expense exceeding the amount of the balance due to the contractor. It appeared, in the case referred to, ${ }^{35}$ that the architect had given certificates in the amount of \$2,950.00 when he should have only certified the sum of $\$ 2,295.00$. The owner was allowed to deduct from the amount paid the architect for his services, the excess amount which he had paid to the contractor as a result of the error in certification. This doctrine of the liability of the architect in the matter of the issuance of certificates, based upon his neglect to use reasonable care and diligence, should be construed and read in the light of the fact that where no special manner of inspection is specified in the contract the courts, in at least one of the States, have held that there is no duty imposed upon the architect to make, before issuing a certificate, a special inspection of the work done, sufficiently detailed to satisfy him not only that the work covered by the particular certificate in question has been performed, but that it has been performed properly and in accordance with the contract requirements. $^{36}$

${ }^{35}$ Irving v. Morrison, 27 C. $\quad{ }^{36}$ Vigeant v. Scully, 20 Ill. P. (Upper Canada) 242. App. 437. 


\section{CHAPTER V}

\section{DEATH OF ARCHITECT AND OWNERSHIP OF PLANS}

$\S 5$ I. Death of Architect.-The contract between the owner and the architect, as in the case of any other contract or relationship of a professional character, is in its very nature personal, and it follows, accordingly, that where the architect dies before the work on which he is engaged has been completed, the right to complete the work does not survive to his executor, and that, on the other hand, the owner can not, under such circumstances, impose upon the executor a liability to perform it. ${ }^{1}$ This rule does not mean, however, that where, under his contract with the owner, the architect has, at the time of his death, already earned and become entitled to a part of his compensation, the executor can not protect the estate in this connection; and where one employed as a consulting engineer had partly completed, prior to his death, the work on which he was engaged and, under his contract of employment, had earned certain of the installments in the form of which, quarterly, it was agreed that his compensation should be paid to him, his personal representative was allowed to recover from the

${ }^{1}$ Stubbs v. Hollywell R. Co., Hall v. Wright, 96 E. C. L. L. R. 2 Exch. 3II; and see 746. 
employer the amount of the installment which had been earned at the time of the death of the engineer. $^{2}$

$\S 52$. Ownership of Plans.-Whether the plans prepared by the architect are to be considered his property, or the property of his client, is a question of long standing between them. As a practical matter the architects, by insisting on their claim that the plans are their property, seem to have induced the public generally to acquiesce in this point of view. As a matter of fact, however, unless there be a specific provision in the contract whereby it is agreed that the plans are to be and remain the property of the architect, they must be legally considered, it seems, as the property of the employer who has ordered, accepted, and paid for them. ${ }^{3}$ This is on the perfectly logical theory that the plans are an essential part of the building contract, and that while the architect, under the rule that work embodied in some material form and resulting from an individual's mental conception and labor is to be considered the property of the one creating it, has property rights in the plans prepared by him, yet when these plans have been prepared, pursuant to his employment, and the services expended in their production have been paid for, and the plans published to the world by filing or otherwise, the right of ownership in

${ }^{2}$ Stubbs v. Hollywell R. Co. delphia, 9 Philadelphia, Pa. L. R. 2 Exch. 3II, supra.

${ }^{3}$ Moffatt v. Scott, 8 L. C. A. D. 356. Jur. 3ro; Windrim v. Phila- 
the plans passes from the architect to the client who has employed him. The New York court has stated the matter well in the case last cited, where, citing and quoting from a decision ${ }^{5}$ affirming the rule that

"Every new and innocent product of mental labor which has been embodied in writing or some other material form," is "the exclusive property of its author, the law securing it to him and restraining any other person from infringing his right,"

the Court goes on to say that, nevertheless, where the architect prepares plans and specifications and files them with the Building Department and superintends the construction of the house and receives his compensation, he has, thereby,

"published his work to the world and can have no exclusive right in the design or in its reproduction.... It seems to us that all of the property rights in these plans, if they had any value as property after the publication, belonged to Litson (the client), rather than to the plaintiff (the architects) in this action ..."

It is of interest to note that Article 7 of the new Standard Form of the General Conditions of the Contract, issued by the American Institute of Architects, and included in Appendix B, provides that: "All drawings, specifications and copies thereof, furnished by the architect, are his property. They are not to be used on other work and, with the exception of the signed contract set,

4 Wright v. Eisle, 86 N. Y. A. D. 356 .
5 Palmer v. DeWitt, $47 \mathrm{~N}$. Y. 532, citing Shortt on the Law of Literature, 48. 
are to be returned to him on request, at the completion of the work. All models are the property of the owner." While the parties to the construction contract and general conditions are the owner and the contractor, rather than the owner and the architect, the provisions quoted are nevertheless indicative of a realization of the necessity of a definite agreement in regard to the plans, if the rights of the architect therein are to be properly protected. To prevent the urging of the possible argument that as between the owner and the architect, unless the latter be a party to the contract and general conditions, there would be no consideration for the agreement of the owner recognizing the property rights of the architect in the plans, it is advisable that a memorandum of agreement in this connection be entered into direct between the architect and the owner. Under such circumstances, no such technicality could be urged to defeat the intent of the parties as outlined in the agreement between them. 
PART II

THE OWNER AND THE CONTRACTOR 



\section{CHAPTER I \\ IN GENERAL}

§53. Introductory.-Many of the mutual rights and duties of the owner and the builder, especially in the matter of extras, superintendence, certificates and the like, have been already referred to. The lien rights of the contractor, of the subcontractor, and of the material-man, will be considered separately under "Liens" and in such detail that it will not be necessary to advert to them here. A brief summary of some of the matters already discussed, in their relation purely to the duties and rights of the owner and builder, is, however, appropriate at this point, before entering upon a detailed discussion of the construction contract.

$\S 54$. Compensation of Builder-Extras and Modification of Contract.-A very considerable number of the differences arising between the owner and contractor may be traced directly to the matter of extras. It is quite natural that this should be the case, inasmuch as it is in connection with extra work, especially, that the owner ofttimes feels that the expense of the work is being added to needlessly or improperly and, on the other hand, the contractor feels that he is being called upon to perform work not included or 
contemplated in the original contract and for which he should receive full pay. To support the right of the contractor to recover for extra work and the liability of the owner to pay for same, it must be shown, as the very basis of such recovery and liability, that the work done was properly authorized and that the authority was granted and the work done under such circumstances as to expressly or impliedly charge the owner with such knowledge and approval and acceptance thereof, as will legally render him liable to the contractor for the reasonable or agreed cost of the work.

If the owner himself authorize extra work direct there can, of course, be no question of his liability to pay for same-if the price be agreed upon, upon the theory of the specific contract so made; in the absence of an agreement as to price, upon the theory of quantum meruit. It is probably more often the case, however, that it is the architect who authorizes extra work and where this is done there is at once added to the situation another element, namely, the agency of the architect and his right and authority thereunder to bind the owner for the additional work authorized. A somewhat detailed discussion on this point has already been had. ${ }^{1}$

The questions which arise in this connection usually relate to or depend upon the terms of the building contract and, in so far as this is the case,

1 Part I, Chapter II, "The Architect as Agent of the Owner," pp. 12-35. 
they are considered in the next two ensuing chapters which are devoted to that contract. It has been seen that the general rule is that it is the primary duty of the architect, engaged to superintend the construction of a building, to see that the contract between his client and the builder is carried out in strict accordance with its terms, and that the architect, in the absence of special authorization, is not clothed with any right or authority whatsoever to change or to alter or to modify the terms of that contract, or to make new contracts which involve additional expense, or to authorize alterations in the plans and specifications as already agreed to, or extra work or material not specified in the original contract. ${ }^{2}$

It has been seen, also, that although the owner may, if he desire, constitute the architect his general agent and, by declaring him to be broadly the general agent of the owner, invest him with authority to bind the owner for extras or alterations, yet this is but an exception which proves the general and well established rule that the employment of the architect does not, in itself, constitute him the general agent of the client, but that his agency is limited directly by the terms and provisions of the understanding and agreement existing between his client and himself. ${ }^{3}$

The fact that the work done unexpectedly proves to be more expensive for the contractor than he anticipated, or that he meets difficulties

\footnotetext{
${ }^{2}$ See Part I, Chapter II, ${ }^{3}$ Part I, Chapter II, page pp. 12-25, and cases cited. I7, and cases cited.
} 
for which he has not provided, is not, in itself, any justification for an additional charge by him to cover the extra expense with which he may be burdened under such circumstances. If his contract be explicitly based, in whole or to a material extent, on the estimates of the engineer or architect of the quantity of the material which it will be necessary to use or of the character of the work, and the work necessary, or the quantity of material necessary, prove to be in excess of the amount estimated, or the work prove very materially different in its character from the preliminary description given of it by the architect, the contractor may reasonably claim that if he is to perform the extra work made necessary by such unexpected conditions and by the variances between the actual facts and the representations of the architect, it is but proper that he be reimbursed for the additional expense which such extra work will entail. This claim may be met successfully by the owner if it be shown that it was agreed, or specifically understood by the builder, that the estimates of the architect or engineer were merely approximate and that the contractor was expected to investigate conditions and enter into the contract, not in reliance upon any representations or estimates of the architect or engineer, but as a result of his own investigations and judgment.

If, however, the additional cost of construction, and the unexpected conditions from which it 
arises, are the result of some act or omission on the part of the owner, without fault on the part of the builder, the latter may recover for the extra expense to which he may be put in completing the contract under the altered conditions. For instance, if the owner, by neglecting to take proper care of an adjoining piece of property owned by him, were to allow leakage or other conditions which would undermine or deleteriously affect the work being done by the contractor, and the contractor, as a result of such conditions, should be put to additional expense in completing his contract, for shoring or additional excavation work or the like, he might well maintain an action against the owner for such additional expense, even though in the contract itself it had been specifically stated that the estimates of the architect and his representations, in regard to the character of the work, and of the property, were approximate only, and that the contractor had himself investigated conditions and had entered into the contract solely as a result of, and in reliance upon, his own investigations and judgment. The mere fact that the contractor had investigated conditions and had not depended upon the architect's estimates or statements would not, under such circumstances, excuse the owner, for the reason that the contractor, in making his investigation and decision, had the right to assume and believe that the owner would not, by his own neglect or omission in respect to the adjoining property, 
create new and unforeseen conditions involving additional expense. ${ }^{4}$

It should be remembered that there is a distinction between extra work agreed upon or made necessary after the contract has been executed and put in force, and extra work which is provided for under the first preliminary understanding has been reached, but before the contract has actually become effective. In the latter case, the extra work would entail merely a modification of the proposed contract and a change in the character of the work, taking effect before the final acceptance of the contract. Such work should not really be termed extra work at all, in the ordinary sense in which that term is employed in building contracts and relationships, for the reason that the provisions in regard to it have become merged in, and terms of, the contract, as finally agreed upon. For such work no recovery can be had. ${ }^{5}$

The builder as one of the parties to the construction contract, is chargeable with notice of its provisions, and where the contract provides that no alterations are to be made except upon the written order of the architect, evidence offered, in behalf of the builder, that the architect has orally allowed certain changes in material to be made, is not competent as proof of a waiver by the client of the express provisions of the contract. This rule will be applied even in cases where the archi-

* Sundstrom v. The State, 213 N. Y. 68 , reversing $159 \mathrm{~N}$. Y. A. D. 241 .

${ }^{5}$ Marx v. White Co., $143 \mathrm{~N}$. Y. Supp. I036. 
tect may be an officer of the corporation for which he is acting as architect, and the corporation will not, even under such conditions, be compelled to recognize, as extra work, work done pursuant to the oral permission of the architect when, under the express terms of the written contract, the contractor is chargeable with notice of the fact that the authority of the architect in connection with the construction work is limited to his position as architect. ${ }^{6}$ Where it appears that it is necessary that extra work be done which is of such a nature as to vitally affect the whole contract, and a supplemental agreement for the doing of such additional work is entered into accordingly, the term of the original contract will, by implication, be extended by the time which is reasonably necessary for the proper performance of the supplemental agreement and the completion of the additional work thereby provided for. ${ }^{7}$

$\S 55$. The Architect's Certificate.-If the contract provide, as a condition precedent to the right of the contractor to recover, that he shall receive the certificate of the architect certifying to the proper completion of the work, no recovery by the contractor will ordinarily be allowed where he fails to produce such certificate or to prove that it has been issued by the architect. If, however, the contractor show that the refusal of the architect to issue the certificate has been unreasonable, and

${ }^{6}$ Traitel Marble Co. v. ${ }^{7}$ N. Y. State, etc., Bank v. Brown Bros. Inc., I59 N. Y. Whitehall Water, etc., Co., A. D. 485 . I6I N. Y. A. D. 304. 
in bad faith, the general rule will not be applied and the contractor will be allowed to recover upon proof of these facts, and of the fact that he has complied with the terms of the contract in all substantial particulars. ${ }^{8}$ Similarly, an objection that the certificate has not been issued will be met by proof that the owner has, directly or indirectly, waived this provision of the contract. ${ }^{9}$

Excuse or waiver are facts which must be clearly proven, however, to be effective, and if the contract provide that the production of the architect's certificate is to be a condition precedent to recovery by the contractor, no recovery will be allowed where the complaint fails to allege the issuance of the certificate, or an excuse for its non-production, or a waiver of its production, ${ }^{10}$ and this notwithstanding the fact that there may be evidence that the architect was at the building but seldom, and that prior payments had been made to the contractor during the course of the work without the production by him of the certificates of the architect. ${ }^{11}$

Where, however, upon the contractor failing to complete, the owner completes the work, the fact

8 MacKnight, etc., Co. v. The Mayor, 160 N. Y. 72; Thomas v. Stewart, I32 N. Y. 580; Flaherty v. Miner, I23 N. Y. 382 ; Bowery National Bank v. The Mayor, 63 N. Y. 336; People ex rel. Rapid Transit, etc., Co. v. Craven, 2ro N. Y. 443 ; Thomas v. Fleury, 26 N. Y. 26.
9 Diehl v. Schmalacker, 26 Misc. (N. Y.) 835; Fay v. Muhlker, I Misc. (N. Y.) 32I ; Uvalde, etc., Paving Co. v. Central, etc., Co., 84 N. J. L. 297; Schmulbach v. Caldwell et al., 215 Fed. Rep. 70.

10 Weeks v. O'Brien, I4I N. Y. 199.

11 Shurman v. George Backer, etc., I44 N. Y. Supp. 9. 
that the contract contains a provision that payments shall be made only upon the certificate of the architect will not prevent the contractor, under such circumstances, from recovering on quantum meruit the difference, if any, which there may be between the contract price and the cost of completion. Under such circumstances, the production of the architect's certificate is neither necessary nor material to support the recovery. ${ }^{12}$

In further limitation of the ordinary rule requiring that the certificate of the architect must be secured, it should be noted, that in the event that the refusal or failure of the architect or engineer to give such certificate is a result of an error of law on his part in construing the terms of the contract, the contractor is not barred by his inability to produce the certificate and may recover for the work which he has done, if the same has been in other respects satisfactory and in accordance with the terms of the contract. ${ }^{13}$

Just as the refusal to give the certificate may not be necessarily fatal to the recovery of the contractor, so the fact that a final certificate has been given is not invariably conclusive evidence of the amount due from owner to contractor. In the event, for instance, that there has been a guarantee by the contractor that the completed structure will have a certain capacity or effectiveness in the use to which it is to be put, and it prove that

12 Borup v. Von Kokeritz, 162 N. Y. A. D. 394.
13 Merrill-Ruckgaber Co. v. New York, I60 N. Y. A. D. $5^{1} 3$. 
it is deficient in such respects, the owner, in a suit by the contractor for the unpaid balance of the contract, may properly counterclaim for a breach of such warranty. Evidence of such breach is admissible under these circumstances for the reason that such a warranty survives the completion and acceptance of the contract, and the mere fact that the contract has been completed in accordance with its terms, and the building erected in accordance with the plans agreed upon, is no answer to a claim that in addition to this contract there was a warranty that the building, when completed in accordance with the plans and contract, should be available and efficient for the purposes intended, and that it is deficient in these particulars.

The combination of a provision for arbitration with a provision for the giving of certificates by the architect or engineer, may operate to relieve the contractor somewhat of the strict requirements of the ordinary certificate provision. So, if it be provided both that claims of the contractor shall be approved and passed by the engineer or architect, and that, in the event that the same are not so passed, they shall be determined by arbitration, the contractor, upon the failure of the architect to issue the certificate, will still have open to him the right to have his claim determined by arbitration. At the same time, in a contract so phrased, the contractor may not invoke the rule that a recovery may be enforced where the refusal to certify is improper, without first referring the 
matters in dispute to arbitration in accordance with the arbitration provisions of the contract. ${ }^{14}$

The courts are inclined to give more than ordinary weight to the opinions and testimony of architects regarding the character and conditions of the work, not only on account of their special professional knowledge on these points, but on account also of the somewhat quasi-judicial position which they occupy in superintending the performance of a construction contract. Where, for example, the contractor sues in quantum meruit, and testifies that the owner has prevented performance of the contract by failing to pay an installment due under the contract and has based his refusal solely on the ground that the superintendent of the works has failed to recommend payment, such refusal in itself not giving to the owner, under the contract, the right to refuse payment, and the architect denies the contractor's contention and testifies that the only reason the certificate has not been given is that the work is defective, the evidence is insufficient to show that the owner prevented performance. ${ }^{15}$

Provisions relative to the certificate of the architect are not enforced solely for the benefit of the owner, but may be enforced for the protection of the contractor as well. If, for instance, the contract provide that upon the architect certifying to the default of the contractor, the owner

14 People ex rel. Rapid 15 Borup v. Von Kokeritz, Transit Co. v. Craven, 210 N. I62 N. Y. A. D. 394.

Y. 443 . 
may terminate the contract and complete the work, and that he may, for this purpose, take possession of the tools and materials on the premises, the giving of the architect's certificate is, under such circumstances, a condition precedent to the right of the owner to take possession of the tools and materials and he will not be allowed to assert any right of possession to them until the certificate is given.

Speaking generally, it is in actions by the builder against the owner, to recover the contract price, that the questions involving the acceptance of the work and the issuance of certificates by the architect arise. An examination of the decisions in such actions will indicate what important factors these questions have proved to be in the cases wherein they have been present, and how generally and in how many different jurisdictions they have arisen. ${ }^{16}$

${ }^{16}$ Heidlinger v. Onward Const. Co., 44 Misc. (N. Y.) 555,90 N. Y. Supp. (124 N. Y. St. Rep.) II5; Olsen v. Schwarzwelder, Iog N. Y. App. Div. 282, 95 N. Y. Supp. 65I ; Traitel v. Oussani, 5I Misc. (N. Y.) 667,135 N. Y. St. Rep. (IOI N. Y. Supp.), 105, White v. Abbott, I88 Mass. 99, 74 N. E. 305; Hebert v. Dewey, I9I Mass. 403,77 N. E. 822 ; Loftus v. Jorjorian, I94 Mass. 165, 80 N. E. 235. Bush v. Jones (C. C. A.), I44 Fed. 942 ; Stephens v. Essex County Park Commission (C. C. A.), 143 Fed. 844. Wyman v.
Hooker, 2 Cal. App. 36, 83 Pac. 79. Fitzgerald v. Benner, 219 Ill. 485,76 N. E. 709 ; Barbee v. Findlay, 22I Ill. 25I, 77 N. E. 590; Andrew Lohr Bottling Co. v. Ferguson, 223 I11. 88, 79 N. E. 35. Louisville Foundry Co. v. Patterson ( $\mathrm{Ky}$. Ct. of App. May gth, I906) 93 S: W. 22. Dogue v. Levy, II4 La. 21, 37 So. 995; Filston Farm Co. v. Henderson (Md. Ct. of App. June 27, I907), 67 Atl. 228. Carnegie Public Lib. Assoc. v. Harris (Tex. Civ. App. May 9th, 1906), 97 S. W. 520. Lavanway v. Cannon, 37 Wash. 593, 79 Pac. 
$\S 56$. Damages.-The contractor is in duty bound to see that the work performed by him for the owner is performed in a proper and workmanlike manner, and if this is not the case and reasonable care is not employed and damage to the owner results, the latter may look directly to the contractor for compensation. ${ }^{17}$

While the relationship of owner and contractor is not characterized by the elements of special trust and confidence to the same extent as is the relationship of owner and architect, and while the duties of the contractor to the owner, and of the owner to the contractor, are limited and prescribed almost entirely by the more strictly legal obligations of the one to the other, as set forth in the contract between them, and without those other and implied elements of special obligation and trust which characterize a professional, as distinguished from a business, relationship; nevertheless, the owner and the contractor must deal with one another in absolute and entire good faith. If the owner depart from his duties in this respect and conspire against the contractor, either

III7. Halsey v. Waukesha Springs Sanitarium Co., I25 Wis. 3II, I04 N. W. 94; Modern Steel Structure Co. v. English Const. Co., I29 Wis. 31, 108 N. W. 70. Robins v. Goddard (1905), I K. B. 294.

17 Mohawk, etc., Co. v. Brown, I63 N. Y. A. D. I57; David v. McDonald, 8 L. C. (Lower Canada) Jurist, 44; I4 L. C. Rep. 3I; and see
Newman v. Fowler, 37 N. J. L. 89; compare also Cass County v. Gibson, I07 Fed. 363, to effect that an offer by the builder in good faith to correct defects will entitle him to recover. As to what acceptance will constitute a waiver, see Smith v. Brady, I7 N. Y. I73; Estep et al v. Fenton et al, $66 \mathrm{Ill}$. 467 ; Korf v. Lull, 70 Ill. 420. 
with the architect or others, he is liable to the contractor for any damages occasioned the latter as a result of his conduct. On the other hand, if it appear that the contractor has been guilty of any improper conduct toward, or willful departure from his obligations to, the owner, the latter may recover for the damage caused him by such wrongful acts of the contractor.

It is a well recognized and long established principle that a contract induced by fraud is voidable at the option of the party defrauded. ${ }^{18}$ If, therefore, some concession or agreement be made either by the owner or by the contractor as a result of bad faith or of misrepresentation on the part of the other, the transaction may be deemed a nullity by the innocent party. Thus, if the architect waive the requirements of a written construction contract, with the authority and consent of the owner, such waiver will, nevertheless, not be binding on the owner, if the action taken by the architect and the acquiescence therein of the owner be the result of bad faith on the part of the contractor. ${ }^{19}$

The owner has the right to insist that the workmanship of the contractor be of good character and performed with reasonable skill and care, and if the workmanship be not of such character, but

18 Morrison v. Universal, etc., Co., L. R.. 8 Exch. Cases 197; Rowley v. Bigelow, I2 Pick. (Mass.) 307; Byard v. Holmes, 33 N. J. L. II9; Daly v. Wise, I32 N. Y. 306; Cobb v. Hatfield, 46 N. Y. 533; Baird v. New York, 96 N. Y. 567.

19 Mohawk Overall Co. v. Brown et al., I63 N. Y. A. D. I 57. 
be such as to justify the conclusion that the contractor has been guilty of bad faith and recklessness and improper methods of construction in the carrying out of his contract, the owner may collect from the contractor, as damages, the amount which it may cost him to effect proper repairs, and to correct the faults of construction resulting from the acts or omissions of the contractor. This will be true even if it be shown that the owner authorized the architect to waive the requirements of the written contract, and consented to a different form of construction from that originally specified. No matter what the form of construction may be the owner has a right to expect that the contractor will perform his work in accordance with the form of construction specified, and in a proper and reasonably careful manner. ${ }^{20}$

§57. Right to Plans.-It has been already noted that the owner, in the absence of a special agreement between him and the architect, is entitled to the plans which he has ordered and for which he has paid or became obligated to pay. While there is no element of ownership in the rights of the builder in the plans, nevertheless, the fact has been recognized that he has a certain right to use and to hold them in his possession during the progress of the work. The specific case in which this right has been referred to, however, involved the right of the builder to the plans as between himself and the architect and a

${ }^{20}$ Mohawk Co. v. Brown et al., I63 N. Y. A. D. 157. 
question of criminal conduct and bad faith on the part of the latter. ${ }^{21}$ It should not be considered, therefore, as at all conclusive in an ordinary case, even as between architect and contractor. All that can be said in regard to this right as between the owner and the builder is that there might, conceivably, be certain circumstances under which the taking of the plans by the owner from the builder would be improper, and certain rights to which the court, under special conditions, would probably hold the builder to be entitled, such as the right to hold the plans as a part and as evidence of the contract between himself and the owner or for purposes of proof of his own proper compliance with the terms of the contract between them.

$\S 58$. Liability of Contractor for $W$ ork of Subcontractor.-A contractor is bound to make good any defects in the work which are the result of improper work by his subcontractor. Under such conditions he will naturally desire to secure reimbursement from the subcontractor if possible.

$\S 59$. Recoupment from Subcontractor.-An agreement by a subcontractor to perform work under the supervision of an architect, and in accordance with the latter's plans, will be sufficient to sustain a recovery by the general contractor from the subcontractor of any amounts which the former has been compelled to pay by reason of the architect's requiring him to replace work performed by the subcontractor, because the same ${ }^{21}$ Lonford v. Diettrich, 87 Ala. 250. 
was defective and not in accordance with the plans. The subcontractor, however, cannot be held to account for provisions in the specifications which refer merely to the amount to be paid to the contractor by the owner, and if he prove that he has performed the work which he has agreed to perform, in accordance with the plans and specifications, his right to recover will be sustained. $^{22}$

$\S 60$. Time of Payment.-In some instances it may be that the contract specifies no fixed time for payment, as distinguished from the usual contract provisions whereby installment payments at designated times or stages of the work are provided for. Where no fixed time for payment is provided, the contractor is not entitled to payment for the work until the performance thereof has been completed.

§6I. Substantial Performance.-The doctrine of substantial performance will be again referred to in another connection ${ }^{23}$ and the rules, which will be seen to characterize that doctrine, when applied to a proceeding by the builder to foreclose his lien, may, in general, be said to characterize it also when applied to a suit by the builder to recover the amount which he may claim to be due to him under the building contract.

While the doctrine of substantial performance was developed to do away with the injustice which an insistence on an absolutely literal and strict ${ }^{22}$ Martin v. Oberle, 85 N. $\quad{ }^{23}$ Part III, Liens, p. 163. Y. Misc. 35 . 
performance of the contract would often work the contractor must, nevertheless, comply with each and every one of the substantially important and necessary elements and provisions of the contract. If he agree to perform certain work according to law, he can not recover for the work even though he has performed it, if it appear that he has not complied with certain material provisions of the law. For the purposes of this rule, a contractor who has failed to comply with the Rules of the Tenement House Department is considered to have failed to comply with the provisions of the law. ${ }^{24}$

Just what constitutes, in a given case, substantial performance, will depend upon all the conditions surrounding the work and the terms of the contract in that specific case. What might, for instance, under certain conditions, be sufficient to sustain a conclusion that the contract has been substantially performed, might, under other conditions, be totally inadequate for that purpose.

In a rather recent case a contractor agreed to excavate a cellar I62 feet in length, I02 feet in width, and 8 feet in depth. The cellar which he excavated measured 16I feet in length by 99 feet 8 inches in width and 8 feet in depth. It was held that he had not substantially performed his contract and that he could not recover the balance unpaid thereon and for which he sued. ${ }^{25}$

24 Bonagur v. Purificato, 146 N. Y. Supp. 1070.
25 Paladino Contracting Co. v. Walsh et al., I44 N. Y. Supp. 7. 


\section{CHAPTER II \\ REQUISITES OF CONSTRUCTION CONTRACT}

\$62. In General.-There is naturally nothing of more importance as affecting the mutual rights and liabilities of the owner, the builder, and, to a certain extent, the architect, than the construction contract, in that it is to the contract that the courts will look primarily in determining and interpreting the special rights and liabilities of the parties. ${ }^{1}$

While in the absence of a specific statute it is not necessary that the contract, if it is to be performed within a year, shall be in writing, ${ }^{2}$ yet the custom of reducing the terms of the understanding to written form has now become so well-nigh universal, and the desirability of a contract in definite written form is so apparent, that in referring to the contract hereafter it may be assumed, unless it is otherwise definitely indicated, that where the word contract is used a written contract is referred to.

It is one of the prime requisites of any contract that a valid consideration be present, and the ${ }_{1}^{1}$ O'Keefe v. St. Francis's ${ }^{2}$ Champlain Construction Co. Church, 59 Conn. 55 I.

v. O'Brien, II7 Federal 271. 
building contract is no exception to the rule. ${ }^{3}$ It is essential also that there be present in the contract the element of mutuality-the obligation upon the builder to do the work and upon the employer to make payment for the work that is done; ${ }^{4}$ a mere memorandum of prices signed by the parties cannot be held to be a binding contract, in the absence of an undertaking by the parties to perform the agreement. ${ }^{5}$ To these more fundamental requisites of a valid contract must be added the element that the building contract must be so phrased as to allow the intent of the parties to be deduced therefrom with a reasonable degree of certainty. In a comparatively recent case ${ }^{6}$ before the Federal Supreme Court, it appeared that there was a variance between the provisions of the contract and the specifications, and the court, in its opinion by Chief Justice White, referring to the irreconcilable provisions of the contract and specifications, said:

"it is evident that there was a conflict so irreconcilable between the essential provisions of the assumed contract as to render it impossible to enforce it as an agreement between the parties ... . under the circumstances, therefore, the court erred in treating the contract as a valid agreement."

Analogous to the foregoing rule is the rule that where the specifications, in exact accordance with which it is covenanted the building must be

3 Majory v. Shubert, 82 York, 49 Misc. (N. Y.) II4. (N. Y.) A. D. 633 .

4 Durkin v. City of New consin 369 . 
erected, are so indefinite and so erroneously drawn as to make impossible any proper interpretation of them, or the erection pursuant to them, of a building of any known dimensions, the contract will not be enforced. ${ }^{7}$

Other elements of the valid contract which should be specially noted are: That the contract must not contemplate a building in its very character capable of being used for an illegal purpose, ${ }^{8}$ and that it must, also, be so drawn as to comply with the provisions of the building codes and regulations in force where the building is to be erected. ${ }^{9}$

It is not necessary that the construction contract, any more than an ordinary contract, be contained in one instrument solely, and other conditions or provisions may be incorporated in the contract as a part thereof by proper reference to them in the main instrument. ${ }^{10}$ Thus the provision contained in Article 4 of the new standard form of agreement issued by the American Insti-

6 United States v. Ellicott, 223 U. S. 524.

${ }^{7}$ Lyle v. Jackson Co., 23 Arkansas 63 , and see Turney v. Bridgeport, 55 Conn. 4 I2.

${ }^{8}$ Spurgeon v. MacElwain, 6 Ohio 442.

- Burger v. Koelsch, 77 Hun. (N. Y.) 44; Eastern, etc., Metal Co. v. Webb Granite, etc., Co., 195 Mass. 356; but see Morse v. Maurer, $35 \mathrm{~Pa}$. Super. Ct. 196, holding that where the contract has been performed in accordance with

its terms, the owner may not defend on the ground that additional expense will be required to make the work conform with the building regulations; and see Girard Life Insurance Co. v. Cooper, 162 U. S. 529; Disken v. Herger, 73 N. Y., A. D. 453.

${ }^{10}$ Francis v. Heine, etc., Co., I05 Federal 4I3, reversed, but on other grounds, Iog Federal 838; Howard v. Pensacola, etc., Co., 24 Florida 560. 
tute of Architects and approved by the National Association of Builders' Exchanges and other associations, providing that the drawings and specifications are made a part of the contract, is good; and when they are so incorporated in the contract, they become at once, by virtue of such incorporation therein, elements of direct importance in determining the rights of the various parties. ${ }^{11}$ The mere fact that the plans and specifications are not attached to the contract, although it is agreed that they shall be, has been held immaterial where the contract itself is suffciently definite to determine the rights of the parties. ${ }^{12}$

While there would seem to be no damage occasioned either party by not attaching the plans and specifications as agreed where the contract is absolutely definite and clear without them, nevertheless, where the provision that they shall be attached is made a definite term of the contract, and is clearly inserted for the purpose of protecting the parties, by making definite and clear every term of their agreement, it is unsafe to attempt to extend the rule as stated so as to include such a case, or to take liberties with the contract by not attaching the plans and specifications, when it has been specifically covenanted as a term of the contract that they shall be attached.

11 Wilemet Steam, etc., Co. v. Los Angeles College Co., 94 Cal. 239; Howard v. Pensacola, etc., Co., supra., 24 Fla. 560; Cleveland, etc., Railroad Co. v.
Moore, I70 Ind. 328; but see Hayes v. Wagner, II3 Illinois Appeals 299.

12 Womble v. Hickson, 9 I Arkansas 266. 
$\S 63$. Importance of Statutory Provisions.The provisions in the various States in regard to construction and other contracts differ, as is natural, in many respects, and, as in the case of a lien, the only really safe course to pursue in any given case is to become thoroughly acquainted with the special provisions of the statute in the jurisdiction in which the case arises. In California, it has been held ${ }^{13}$ that the contract cannot support an action for damages for its breach unless it is recorded, and that where an ordinance specifies that a permit must be obtained, a contract to construct without a permit is not lawful and will not be allowed to form the basis of a civil action. ${ }^{14}$ In Connecticut an agreement to build from plans and specifications not submitted to and approved by the officers by whom the statute required they should be approved, has been held to be void. ${ }^{15}$ While the foregoing are instances of special State statutes they should be noted, especially, as excellent examples of the rule that prudence requires that in the making and in the performance of the contract, all the parties should give proper heed to such ordinances and statutes as may apply, even if it be considered that their application is not necessarily clear or of any considerable importance.

$\S 64$. Void and Illegal Contracts.-In this same connection a distinction should be noted between

\footnotetext{
${ }^{13}$ Condon v. Donohue, 160 Cal. 749. 15 Wilcox Manufacturing Co. v. Brazos, 74 Conn. 208.

14 Smith v. Luning, II Cal. 308.
} 
a contract which is wholly void, because it is not properly consummated, or because it contemplates the doing of an illegal act, and a contract which in itself is perfectly lawful, but is not performed in a lawful manner. The latter contract will not be declared illegal as a whole so as to prevent a recovery under it. $^{16}$ The mere carrying out of a contract in an illegal way does not make the contract itself illegal, ${ }^{17}$ and even where the contract contains certain provisions which are not in accordance with statute or ordinance, it seems that its validity may possibly in some cases, and especially where nothing illegal was intended, be sustained. ${ }^{18}$ The requirement that the contract shall not usurp the jurisdiction of the courts is referred to elsewhere. ${ }^{19}$

${ }^{16}$ Fox v. Rogers, I7I Mass. ${ }^{18}$ Favor v. Philbrick, 7 New 546. Hampshire 326; Waugh v.

17 Barry v. Cape, I5I Mass. Morris, L. R., 8 Q. B. 202. 99. 19 See $\S 7$ I, p. I30. 


\section{CHAPTER III}

\section{TERMS AND OPERATION OF BUILDING CONTRACT}

$\S 65$. The Architect as Arbitrator.-One of the provisions of the ordinary contract which may be extremely helpful, if properly drawn and understood, and at the same time is perhaps as likely to cause difficulty as any other, is the provision dealing with the finality of the decision of the architect and with his position as arbitrator. A provision that the decision of the architect, in regard to the construction and meaning of the drawings and specifications, shall be final is proper, and is recognized as entirely valid by the courts. Indeed, a provision in much fuller form and covering many points which the provision referred to would not cover, such as a provision that the certificates, determinations and decisions of the architect shall be final and conclusive, has been recognized as valid, both by the Federal courts, by the courts of New York and by the courts of other States and of other countries. ${ }^{1}$

${ }^{1}$ Ripley v. United States, Handy v. Bliss, 204 Mass. 223 U. S. 695; Conners v. 513; Brown v. Decker, 142 United States, I30 Federal Pa. State 640; O'Brien v. 609; Farrell v. Levy, I39 (N. Reg., 4 Can. Supreme Court Y.) A. D. 790 ; N. Y. Building 529; Courtney v. Provincial Co. v. Springfield, etc., Co., 56 Commission, 4 I Nova Scotia A. D. (N. Y.) 294; Sweet 7r.

v. Morrison, II6 N. Y. I9; 
$\S 66$. Limitation of Rule.-In restriction of the general rule as stated it should be noted that its application is dependent upon the absence of fraud, ${ }^{2}$ or mistake, ${ }^{3}$ in the transaction. A provision that the architect is to decide the true construction and meaning of the drawings and specifications, does not apply, the New York courts have held, to disputes regarding the construction of the contract. In a case where the question related to the necessity of the contractor filling in between iron beams on the basement floor with terra cotta blocks, under the provisions of the contract between him and the main contractor, it was held that this had nothing to do with the drawings and specifications, and that the decision of the architect relative thereto was, therefore, not controlling. ${ }^{4}$

Another example of the comparatively strict construction which the courts have placed, in some instances, upon the provisions vesting the architect with large powers of decision or arbitration, is the holding of the British courts that, even where it is provided that any question arising between owner and contractor, or relating in any way to the contract, or involving the determination of a dispute between any of the contractors in regard to the building, shall be deter-

2 Ripley v. U. S., 223 U. S. Co. v. Springfield Co., 56 A. D. 695 ; N. Y. Building Co. v. (N. Y.) 294, supra.

Springfield Co., 56 A. D. (N. 4 Isaacs v. Dawson, 70 A. D. Y.) 294, supra.

3 Farrell v. Levy, I39 A. D. N. Y. 537.

(N. Y.) 790 ; N. Y. Building 
mined by the architect, whose decision shall be absolute and final, yet, the differences between the contractor and his employees, as to extras, will not be covered by such a provision, and the provision will be applied only to disputes in regard to the manner of carrying on the different departments of the work. ${ }^{5}$

While the courts have applied the restrictions noted, in the application of the general doctrine, it is still true that they have, with substantial unanimity, recognized the validity of provisions vesting the architect with many different and broad authorities in his character of supervisor of the works and of arbitrator of disputes arising in connection therewith. Thus they have sustained and enforced the provisions so common in the building contracts and general conditions in use at the present day, providing that to the architect may properly be left the determination of any matters of differences, ${ }^{6}$ whether relating to the quantity, quality or value of the work done; ${ }^{7}$ or to payments; or to the securing of certificates preliminary to the payment of moneys due ${ }^{8}$. or to performance ${ }^{9}$ or to the measurement of the work; ${ }^{10}$ or to loss or expense or

- Pashby v. Mayor, etc., of nagh, 38 Iowa 286; OlderBirmingham, 86 E. C. L. 2.

- Mitchell v. Dougherty, 86 Federal 859.

${ }^{7}$ Elliott v. Missouri, etc., Co., 74 Federal 707; Chicago, etc., Co. v. Price, 138 U. S. 185.

${ }^{8}$ Wilcox v. Stephenson, 30 Fla. 377; Mitchell v. Kavashaw v. Garner, 38 V. C. Q. B. 37 .

- Wilcox v. Stephenson, 30 Florida 377; Schliess v. Grand Rapids, I3I Michigan 52.

${ }^{10}$ McMahon v. N. Y. Co., 20 N. Y. 463 . 
damage occasioned the owner by reason of a fault of the builder. ${ }^{11}$ Under certain conditions this general rule may not apply. For instance, the provision requiring that the certificate of the architect must be secured before payment can be successfully demanded, will not be enforced where the death of the architect has intervened; ${ }^{12}$ and the provision making the architect the arbitrator of the amount or value of the work performed, or of the correctness of its performance, will not prevent the question of substantial performance being raised, ${ }^{13}$ or prevent the owner from refusing payment on the ground that substantial performance has not been had. ${ }^{14}$

$\S 67$. Extras.-The importance of any contract provisions in regard to extras has been already referred to. It should be noted here, however, that the ordinary contract provision requiring that extra work be authorized in writing, is of more than ordinary importance in the present connection.

It is especially advisable on account of the disputes that may arise in connection with this provision, that it be so phrased as to preclude any misunderstandings or difficulty, so far as this can possibly be done. The Connecticut courts have recognized as valid and have enforced the following form of proviso: "The contractor shall make 99.

11 White v. Abbott, I 88 Mass.

12 Pleasant College v. Colett, I42 Kentucky 342.
${ }^{13}$ Schliess v. Grand Rapids, I3I Michigan 52.

14 Oberlies v. Bullinger, 75 Hun. (N. Y.) 248 . 
no claim for extra work unless the same shall be done in pursuance of a written order from the architect, and all such claims shall be made to the architect in writing before the next ensuing payment, or shall be considered abandoned by the contractor." ${ }^{15}$ This form might well be made a trifle fuller to prevent any possibility of mistake, but is interesting as exemplifying the main and essential points which the contract in this connection should cover. The disposition of the courts is to protect the owner in regard to extra work, by requiring that contract conditions precedent in regard thereto must be strictly complied with. Even if there be a separate provision in the contract to the effect that disputes in regard to the value of extra work must be submitted to arbitration, yet this provision will not in any way negative the effect of a provision requiring the builder to produce the architect's certificate of the satisfactory completion of the extra work, inasmuch as the arbitration provision in such a case has to do merely with the value of the extra work, as distinguished from the proper completion thereof. ${ }^{16}$ The courts have likewise very generally upheld and recognized the validity of the other provisions of the ordinary building contract, such as the provision that no extra work shall be done without the written order of the architect, and that no payment need be made for it, if done, 15 O'Keefe v. St. Francis's Church, 59 Conn. 551. ${ }^{16}$ Fox v. Powers, 65 (N. Y.) A. D. II2. 
without the production of the architect's order. ${ }^{17}$ The order may, however, be implied from some additional act of the parties, such, for instance, as the adoption of new specifications requiring extra work, an act which is, in itself, equivalent to a proper order for such work. ${ }^{18}$ The validity has been upheld also of provisions that there shall be no departure from the contract terms or from the specifications or drawings, without the consent of the architect or engineer in charge, ${ }^{\mathbf{1 9}}$ and that there shall be no subletting of the contract unless the owner's consent be secured. ${ }^{20}$ While these provisions are inserted for the benefit of the owner, he may, of course, waive them if he elect so to do. ${ }^{21}$

$\S 68$. Right of Owner to Complete.-There is no doubt that the ordinary provision that upon the failure of the builder to do the work the owner may complete the contract and employ others to that end is good; ${ }^{22}$ and the courts have been liberal in their construction of such provisions. $^{23}$

Where the contractor leaves the work unfinished and fails to complete and the owner, un-

17 Langley v. Rouss, $185 \mathrm{~N}$. Y. 201 .

18 Hedden Construction Co. v. Rossiter, etc., Co., I36 N. Y. A. D. 60I-compare O'Keefe v. St. Francis's Church, 59 Conn. 55 I.

19 White v. San Rafael, etc., Co., 50 Cal. 4 I7.
${ }^{20}$ Danforth v. Tennessee, etc., Co., 93 Alabama 6r4.

21 Danforth v. Tennessee, etc., Co. supra; Bartlett v. Stanchfield, I48 Mass. 394, opinion by Holmes, J. 22 Mahoney v. Oxford Realty Co., I33 A. D. (N. Y.) 656.

${ }^{23}$ Duplan Silk Co. v. Spencer, II5 Federal 689. 
der his contract right to do so under such circumstances, comes in and completes, it has been argued, in behalf of the contractor, that the presumption is that the balance of the contract price remaining unpaid at the time of the abandonment of the work by the contractor will be sufficient to defray the expense of completing the work. This contention is manifestly untenable and the law will not raise or recognize any such presumption under these circumstances. ${ }^{24}$

$\S 69$. Suspension of Work by Mutual Consent. -It often happens that work is suspended by mutual consent of contractor and of owner. In such a case before the contractor can properly proceed to recover the profits of the contract, he must take some steps to continue the work. An action brought by him before he has made any attempt to continue the work, and when there has been no refusal on the part of the owner to allow him to continue the work and complete the contract, is premature. ${ }^{25}$

$\S 70$. Liquidated Damages.-Upon the question of liquidated damages it is very difficult, if not impossible, to state any definite, enforcible and yet comprehensive rule. The provision that, in the event of delay in the completion of the contract, a certain sum shall be paid to the owner, as damages for each day or similar period that the

24 Brainard v. The County of Kings, 155 N. Y. 538; TriBorough, etc., Co. v. Wechsler Realty Co., I63 N. Y. A. D. gor.
25 Dreyer v. McCormack Real Estate Co., I64 App. Div. (N. Y.) 4 I. 
work shall remain unfinished, is usually and in itself unobjectionable. ${ }^{26}$ In one of the cases last cited ${ }^{27}$ the clause in the contract provided that

"the contractor shall pay to the owner Ten (10) Dollars for every day thereafter that the said work shall remain unfinished as and for liquidated damages,"

and in another case ${ }^{28}$ it was provided:

"It is mutually agreed and understood that in the event of said interior finish herein contracted for not being entirely finished on or before the 15th day of March, 1905, that the actual damages sustained by the owner will be difficult of computation; therefore it has been agreed and hereby is agreed by and between the parties hereto that in the event of the failure of said contractor to have all of said interior finish of main entrance and eighth floor completed on or before the 15th of March, 1905, there shall be due and payable and said contractor shall pay to the said owner the just and full sum of $\$ 50.00$ per day for each and every day after March 15th, 1905, that the same or any part thereof, remains unfinished and incomplete, and that said sum is hereby agreed upon as liquidated damages."

These provisions were sustained as proper provisions, under the circumstances of their respective cases, for liquidated damages, as distinguished from penalties. It must not be considered, however, that it was due to any magic in the language used that the court sustained them, for it is a well-

${ }^{26}$ Kelly v. Fejervary, 78 Northwestern 828; Mills v. Paul, 30 Southwestern 558; Chapman Decorative Co. v. Security, etc., Co., 145 Fed. 434, aff'd I49 Fed. I89.
${ }^{27}$ Kelly v. Fejervary, $78 \mathrm{~N}$. W. 828 , supra.

28 Chapman Co. v. Security Co., I45 Fed. 434, supra; and see Standard Documents, Appendix B, p. 255 . 
recognized rule that in construing provisions of this character the courts will look at the intention of the parties, the subject matter, and the nature of the agreement, and from these determine the meaning of the wording used. ${ }^{29}$ The reason that the courts will exercise special care in dealing with this point is that, under the law, provisions for liquidated damages are recognized as valid, while a provision which constitutes a penalty, will not be enforced; where such a provision is found the courts will use their own judgment in awarding such damages as they deem reasonable.

The question which must always be determined, therefore, is whether or not, in a given case, the words used, combined with the intention of the parties and with all the attendant circumstances, are to be construed as intending or providing proper liquidated damages, or are to be construed, on the other hand, as a penalty, and therefore as unenforcible. The wording, however, is not entirely negligible by any means, for where it is provided that the amount specified is to be considered as liquidated damages the burden is upon the builder to show that, in reality, the provision constitutes a penalty, ${ }^{30}$ while if the sum named is alluded to as a penalty the burden is upon the owner to show, by a preponderance of proof, that it was intended to be and may properly be considered as liquidated damages. ${ }^{31}$ It has been held that

29 Ward v. Hudson, etc., Co., I25 N. Y. 230.

${ }^{80}$ Mills v. Paul, 30 S. W.

${ }^{31}$ Small v. Burke, 92 A. D. (N. Y.) 338. 558. 
where the sum mentioned is disproportionate to the damage which will presumably or probably ensue, or to a degree of loss which is ascertainable, it will be construed as a penalty. ${ }^{32}$ Similarly, an agreement to build in a specified time, and in a particular manner, and in the event of failure to meet these conditions, to pay a gross sum specified in the contract has been construed to be a penalty. ${ }^{33}$

The element most helpful in securing the interpretation of the contract provisions as provisions for liquidated damages is the element of uncertainty in the ascertainment of the loss which will result from delay. It may, indeed, be stated broadly and as a general rule, that in the case where it is impossible to ascertain, or where it is impossible to ascertain with any degree of exactness, the damage which will result from the delay, a situation will be presented where the sum named in the contract as damages if not clearly out of proportion to the probable loss will be considered to be damages and will not be construed to be in the nature of a penalty. ${ }^{34}$ And this may be true, even where the word penalty is used. ${ }^{35}$ In the

32 Coen v. Birchard, 124 Iowa 394-holding a proviso for the payment of $\$ 5$ a day a penalty, where the rental value of the building was shown to be but $\$ 25$ per month; and see Ward v. Hudson River, etc., Co., 125 N. Y. 230-indicating, however, that provision would have been held to be for damages, if house had been for private use as a residence.

33 Tayloe v. Sandiford, 7 Wheat (U. S.) I3, opinion by Marshall, C. J.

34 McCullough v. Moore, I I I Illinois Appeals 545 .

35 McManus v. Rothschild, 25

Ontario L. R. 138 . 
words of the New York Court of Appeals in one of the cases already cited: ${ }^{36}$

"Whether the sum agreed between parties to be paid, in the event of a breach of some agreement is termed by them a 'penalty,' or 'liquidated damages,' is not controlling upon the question of construction. Their use of such words is not always conclusive as to their legal meaning. To get at that we must consider the subjectmatter and nature of the agreement and understand clearly the intention of the parties. If it shall then appear that the damage and loss, which may be presumed to result from non-performance, are uncertain and incapable of exact ascertainment, then the payment or liability fixed by them must be deemed to be liquidated damages and recoverable as such. Where, however, a sum has been stipulated as a payment by the defaulting party, which is disproportionate to the presumable or probable damage, or to a readily ascertainable loss, the courts will treat it as a penalty and will relieve; on the principle that the precise sum was not of the essence of the agreement, but was in the nature of a security for performance. This subject has been reviewed in very many opinions; to a few of the more interesting of which, in the English reports and in those of our State, I direct attention.

"In Lowe v. Peers (4 Burr, 2228, 2229), Lord Mansfield, and in Kemble v. Farren (6 Bing. 14I), Tindal, C. J., discuss the subject. In Dakin $v$. Williams (I7 Wend. 447 and 22 id. 20r ), Nelson, Ch. J., in the first report, and Chancellor Walworth, in the second, review the question in the light of the English and New York cases. See also Hosmer v. True, I9 Barb. 106; Lampman v. Cochran, 16 N. Y. 275; Clement v. Cash, 21 id. 253; Little v. Banks, 85 id. 258.

"The result of an examination of cases is to confirm se Ward v. Hudson, etc., Co., 125 N. Y. 230. 
the idea that it is difficult, if it is even possible, to lay down a general rule applicable to all the cases which arise where parties have undertaken to provide against a loss consequent upon a breach of an agreement. We may, at most, say that where they have stipulated for a payment in liquidation of damages, which are in their nature uncertain and unascertainable with exactness, and may be dependent upon extrinsic considerations and circumstances, and the amount is not, on the face of the contract, out of all proportion to the probable loss, it will be treated as liquidated damages."

A provision for liquidated damages will not be affected or negatived by another clause in the contract, referring to arbitration the matter of any damage caused by delay in the performance of the work. ${ }^{37}$

$\S 7 \mathrm{I}$. Contract Not to Usurp Jurisdiction of the Courts.-Finally, in regard to the provisions of the building contract it should be noted that the courts, while ready to give a broad construction to all proper provisions, for the purpose of recognizing and enforcing the intent of the parties, will, nevertheless, not countenance provisions which are of such a character that, if enforced, they will oust the courts of jurisdiction.

The reference of disputes to arbitration is to be encouraged and the parties may enter into such proper arbitration covenants as they will, but care must be taken, if these are to be upheld and enforced, that they do not invade the province of the courts, or attempt to leave to arbitration questions

${ }^{37}$ Drumheller v. American Surety Co., 30 Wash. 530. 
which it is the natural duty and province of the courts to pass upon. ${ }^{38}$

In the case last cited the Court, under the facts there present, decided that the clause in the contract to which objection was made was not such that it should be held void as tending to oust the courts of jurisdiction and proceeded thus to state the distinction between provisions valid and invalid in this respect:

"The question presented by this demurrer is whether the clause in the contract above referred to, comes within the rule which nullifies contracts ousting the courts of their jurisdiction, or within another and equally well-established rule, that parties may covenant that no right of action shall accrue until a third person has performed specific acts or determined certain differences between them. The line of demarcation between the two classes of cases is clear and distinct. The difficulty, if any, lies in the application of particular facts to a clearly defined rule. In Seward v. City of Rochester (I09 N. Y. I68) this rule was stated in the following language: 'The distinction between executory agreements of arbitration which oust a court of jurisdiction and, therefore, are rejected as a bar, and those which are sustained as a sole remedy between the parties, is carefully drawn and fully discussed in Delaware \& Hudson Canal Co. v. Pa. Coal Co. (50 N. Y. 250).' In one class it is said 'the parties undertake by an independent covenant or agreement to provide for an adjustment or settlement of all disputes and differences by arbitration to the exclusion of courts; and in the other they merely, by the same agreement which creates the liability and gives the right, qualify the right, by providing that before a right of action shall

${ }^{88}$ National Contracting Co. N. Y. 439, reversing 67 A. D. v. Hudson, etc., Power Co., 170 (N. Y.) 620. 
accrue certain facts shall be determined or amounts or values ascertained, and this is made a condition precedent either in terms or by necessary implication.' The reasons for the rule thus clearly stated are fully set forth in Delaware \& Hudson Canal Co.v. Pa. Coal Co. (supra) and need not be further adverted to here."

As a guide to determining those cases in general where an arbitration stipulation is valid, and where, on the other hand, it is not valid because it will be construed to be of such a character that it will oust the courts of jurisdiction, it may be stated as a general rule that where the arbitration agreement merely provides that differences arising under the contract shall be submitted to arbitration, under such conditions that the decision of the arbitrators will merely determine certain facts and amounts or values in controversy, which in themselves are conditions precedent to any right of action, the agreement will be upheld. Such an agreement merely qualifies the right of action of the claimant by providing the method by which the facts necessary to legal action may be determined and does not, therefore, so operate to oust the courts of jurisdiction that it will be considered to be illegal. ${ }^{39}$

39 The President, etc., of the Y. 250; Sweet v. Morrison, Delaware \& Hudson Canal Co. II6 N. Y. I9. et al. v. Penn. Coal Co., $50 \mathrm{~N}$. 


\section{CHAPTER IV}

\section{“THE STANDARD DOCUMENTS"}

$\S 72$. In General.-The issuance recently of "The Standard Documents of the American Institute of Architects," which are copyrighted by the Institute and here published as Appendix B by special permission, is a matter of more than ordinary importance.

The documents comprise forms for the agreement and general conditions of the contract, the bond of suretyship, the subcontract, the letter of acceptance of the subcontractor's proposal and various other forms applicable to the relationship and dealings of the owner and the contractor.

The very evident care with which the documents have been prepared, and the fact that they have received the approval of the National Association of Builders' Exchanges, the National Association of Master Plumbers, and the National Association of Steam and Hot Water Fitters, are alike indicative of the real advance marked by their publication. The simplicity of expression and general lack of ambiguity which characterizes them, together with the broad scope of their provisions should do much to prevent misunderstandings between the owner, the contractor and the architect, and to standardize on a mutually 
satisfactory and equitable basis, the general rights, duties and liabilities of the several parties.

The provisions with reference to the ownership of drawings, the status of the architect, the decisions of the architect, liens, the relations of the contractor and subcontractor, and the rather full provisions for arbitration, are all of special interest to the architect.

The form of the subcontract is so drawn that the general conditions of the contract as between the owner and the contractor are, by reference, made a part thereof. This is important in view of the various provisions in the general conditions referring to the obligations of the subcontractor. It will be noted that the provision governing the ownership of drawings and specifications is a term of the contract between the owner and the builder and may with advantage, therefore, be supplemented by a specific agreement between the architect and the owner to the same effect, if the latter desire to have his ownership of the plans and specifications clearly established and in binding form as between the owner and himself.

The forms are so prepared as to be easily adaptable to any particular circumstances and provision is made for the addition by the parties of such special provisions,-as for instance provisions for liquidated damages-as they may desire.

The documents should be read in the light of the general rules and principles discussed in the 
last two preceding chapters and, especially, in the light of the statutory provisions, and of the legal doctrines, of those particular jurisdictions wherein they may be used. 

PART III

\section{LIENS}





\section{CHAPTER I \\ IN GENERAL}

$\S 73$. Definition.-The application of the law of mechanics' liens to the varying relationships of architect, owner and builder is so frequent, that it seems appropriate that some mention in special detail should be made in regard to it. At the same time, it must be borne in mind, that the law of liens is, in itself, sufficient to provide material for an entirely separate treatise of goodly length. The lien law in a given case can only be properly determined by a reference to the particular laws of the State within the jurisdiction of which the case arises, and the various lien statutes are so dissimilar, in many and substantial details, although all based upon substantially the same general basic principles and ideas, that in the space which can be here allotted to the subject there must, necessarily, be included statements merely of the broader and more fundamental rules, together with examples and notes of such decisions and statutes as are of more than ordinary applicability to the architectural profession and its problems.

A mechanic's lien has been defined to be:

"A claim created by law for the purpose of securing a priority of payment of the price and value of work per- 
formed and materials furnished in erecting or repairing a building or other structure, and as such it attaches to the land as well as the buildings erected thereon." 1

\section{And again to be:}

"a statutory lien upon buildings and other improvements on realty and the realty, favoring certain classes of workmen to secure them priority or preference of payment of compensation for work or materials." 2

And yet again to be :

"a modern statutory right, designated to encourage the erection of improvements, and to protect those whose labor and materials enter into their construction." 3

The lien may be said to be in the nature of a mortgage, ${ }^{4}$ or of a statutory quasi-mortgage founded upon consent, ${ }^{5}$ or of a notice of lis pendens or attachment. ${ }^{6}$

$\S 74$. History of Lien Legislation.-The rule whereby a mechanic, workman, laborer, or material man, contributing by his services to the improvement of realty, is now so generally accorded the right of a lienor was unknown at common law which neither recognized nor allowed these lien

1 VanStone v. Stillwell \& Bierce Manufacturing Co., I42 U. S. 128,136 .

2 Tommasi v. Archibald, II 4 N. Y. A. D. 838 .

${ }^{3}$ Hammond v. Darlington, 84 S. W. (Missouri, 1904) $446,449$.

4 Loomis v. Knox, 60 Conn. 343; Throckmorton v. Shelton,
68 Conn. 413; Kenny v. Gage, 33 Vt. 302; Merchants Insurance Co. v. Mazange, 22 Ala. I68; Pratt v. Tudor, 14 Tex. 37.

5 Cummings v. Consolidated, etc., Water Co., 6r Atl. 353.

${ }^{6} 5$ Words \& Phrases, 4463 ; Sawyer v. Schick, 30 Okla. 353. 
rights. $^{7}$ Equity, too, formerly failed to recognize the lien doctrine. ${ }^{8}$

Gradually the feeling that one had enhanced the value of real estate by his services or by materials furnished or incorporated in the property, should be given a claim against the property, as a means of securing the payment or reimbursement due him for the labor or materials given, became so pronounced as to take form in definite legislation. A number of statutes were passed applying the lien doctrine to certain localities in various of the States, ${ }^{9}$ Pennsylvania appearing to have the honor of having in 1803 prepared the first of the mechanic's lien laws. ${ }^{10}$

$\S 75$. Early Conception and Development of Doctrine.-The earliest conception of a mechanic's lien, as appears from the title itself, was that of a statute designed to protect mechanics, as such. ${ }^{11}$ It was the extension of this primary conception of the doctrine which resulted in the protection under the mechanic lien laws not only of

7 Birmingham Iron Foundry v. Glen Cove Starch Manfg Co., 78 N. Y. 30; Van Stone v. Stillwell, etc., Manfg. Co., I42 U. S. I28; Withrow Lumber Co. v. Glasgow, etc., Co., roI Fed. 863 ; Durling v. Gould, 83 Me. 134; Ex parte Schmidt, 62 Ala. 252.

8 Withrow Lumber Co. v. Glasgow, etc., Co., ror Fed. 863; Slack v. Collins, I45 Ind. 569; Ellision v. Jackson Water Co., I2 Cal. 542; Turnes v.
Brenckle, 249 Ill. 394; Ward v. Yarnelle, I73 Ind. 535.

${ }^{9}$ Cockerill v. Loonam, 36 Hun. (N. Y.) 353; Rafter v. Sullivan, I3 Abbts. Pr. (N. Y.) 262; Hickey v. Schwab, 64 How. Pr. (N. Y.) 8; Heamann v. Porter, 35 Mo. I37.

10 Coddington v. Dry Dock Co., 3 I N. J. L. 477.

11 Savannah, etc., R. Co. v. Grant, 56 Ga. 68; Sweet v. James, 2 R. I. 270. 
mechanics, but of all persons, broadly speaking, who have performed work upon, or perfected or made repairs or improvements to, real property; ${ }^{12}$ such as house-painters, ${ }^{13}$ paper-hangers, ${ }^{14}$ and construction companies. ${ }^{15}$

By extension of the doctrine and the application of greater liberality in the provisions of the lien statutes, the mechanic's lien law as it now stands was brought about so that to-day provisions for mechanics' liens are to be found not only generally in the States of the United States ${ }^{16}$ but throughout the various provinces of the Dominion of Canada as well. ${ }^{17}$ England, probably by reason of the controlling precedent and effect of the common law, did not join in the movement so general in the New World; ${ }^{18}$ and while the movement was especially marked in the Southern States, as in Texas and in California, it was not favorably received in Mexico. ${ }^{19}$

$\S 76 .-$ Constitutionality.-As was naturally to be expected in the case of legislation of this character affecting a special class or classes, and creating rights and privileges long unrecognized, the

${ }^{12}$ Sweet v. James, 2 R. I. utes British Columbia I9II, 270.

13 Martine v. Nelson, 5I IIl. 422.

14 Freeman v. Gilpin, I Phila. 23.

16 Tennis Bros. Co. v. Wetzel, etc., R. Co., I40 Fed. I93. 16 Shaw v. Young, $87 \mathrm{Me}$. 271.

17 Revised Statutes Ontario 1897, Ch. 153; Revised Stat-

Ch. 154; Rev. Stat. of Manitoba I902, Ch. IIo; Consol. Stat. New Brunswick I903, Ch. I47 ; Consol. Stat. of Newfoundland I892, Ch. 88.

18 Shaw v. Young, $87 \mathrm{Me}$. 271.

19 Macondray v. Simmons, I Cal. 393; Stowell v. Simmons, I Cal. 452. 
question of its constitutionality was promptly raised. Although, due to special provisions therein, the statutes were, in many instances, declared unconstitutional, yet, in their broad underlying principle and application, their constitutionality has been repeatedly, and substantially without exception, recognized and upheld. ${ }^{20}$

$\S 77$. Lien a Statutory Remedy.-Stating, perhaps, in another way the fact that mechanics liens were unknown under the doctrines of the common law, it has been repeatedly held that they are absolute creatures of statute and are to be so considered in determining their interpretation and application. ${ }^{21}$ As a corollary to the foregoing rule, it necessarily follows that a substantial observance of all statutory requirements and provisions is essential and a condition precedent to the validity and enforcement of the lien, and that

20 Brooks v. Railway Co., Ior U. S. 443 ; Davis v. Alvord, 94 U. S. 545 ; Glacius v. Black, 67 N. Y. 563; Newark Lime, etc., Co. v. Morrison, I3 N. J. Eq. I33; Blauvelt v. Woodworth, 31 N. Y. 285; Schillinger Fireproof Cement, etc., Co. v. Arnott, 86 Hun. N. Y. I82; affirmed 152 N. Y. 584; White v. Miller, $18 \mathrm{~Pa}$. St. 52 ; Whittier v. Wilbur, 48 Cal. I75; Booth v. Pendala, 88 Cal. 36 ; Laird v. Moonan, 32 Minn. 358; McKeon v. Sumner Building, etc., Co., 5 I La. Ann. I96r; Prince v. Neal Millard Co.,
I24 Ga. 892; First Natl. Bank, etc., v. Trigg Co., $106 \mathrm{Va}$. 327.

21 Van Stone v. Stillwell, etc., Manfg. Co., I42 U. S. 128; Withrow L. Co. v. Glasgow, etc., Co., Ior Fed. 863; Birmingham I. F. Co. v. Glen Cove Starch Manfg. Co., 78 N. Y. 30; Frost v. Ilsley, $54 \mathrm{Me}$. 345; Wolf v. Pa. R. Co., 29 $\mathrm{Pa}$. Superior Court 439; United States Blowpipe Co. v. Spencer, 40 W. Va. 698; Joplin Supply Co. v. West, I49 Mo. App. 78; Dufresne v. Préfontaine, 2I Can. Sup. Ct. 607. 
the notice of lien must itself comply with the terms of the statute in all substantial particulars. ${ }^{22}$

$\S 78$. No Personal Liability.-The mechanic's lien being fundamentally and essentially a claim against realty, it follows naturally that no personal liability is created thereunder, whether as against the owner or as against anyone who, in the absence of statutory provision, would be under no personal liability to the lienor. ${ }^{23}$

The fact already noted, that in every case, in determining lien rights, reference must be made to the particular statute involved, must not be lost sight of, however, and no statutory lien can be acquired in any event by one who cannot properly be classified as coming within the provisions of the special statute under which he claims. For instance, under a statute which gives a lien to masons and to carpenters, a plasterer may not be allowed to come in as a lienor. ${ }^{24}$

$\S 79$. Necessity of Contract.-It should be noted here that as to all mechanics' liens it is a general rule that a contract, direct or indirect, to which the owner of the property is a party, covering the work in connection with which the labor or

22 Tenth National Bank of Philadelphia v. Smith Construction Co., $218 \mathrm{~Pa}$. St. 58I, 67 Atlantic 872 ; Wharton et al. v. Real Estate Inv. Co. et al., I80 Pa. St. I68, 36 Atlantic 725; Knelly v. Horwath, $208 \mathrm{~Pa}$. St. 487, 57 Atlantic 957.
23 Crystal v. Flannelly, 2 E. D. Smith (N. Y.) 583 ; Cox. v. Broderick, 4 E. D. Smith (N. Y.) $72 \mathrm{I}$; Delafield v. Sayre, $3 \mathrm{I}$ Vroom (N. J.) 449; Garrison v. Borio, 6I N. J. Eq. 236; Bonncy v. Ketcham, 5I! Ill. App. 32I.

24 Fox v. Rucker, 30 Ga. 525. 
material for which the lien is claimed is performed or furnished, is a condition precedent to the attaching of the lien. ${ }^{25}$

In addition to the prices specified by the contract the lien includes the value of extra work done or materials furnished. ${ }^{26}$ In New York and other States this doctrine has been restricted to the cases where the extras are furnished pursuant to an agreement between the owner and contractor, and in accordance with the terms of the contract, in the absence of a waiver thereof. ${ }^{27}$ But in Massachusetts in a decision by Mr. Justice Holmes, before the latter's appointment to the Federal Supreme Court, the Court recognized an implied authority in the contractor to sublet portions of the work, and sustained the right of his subcontractor to a lien for extra work. ${ }^{28}$

It may be stated as a general rule that while the necessity of a contract direct or indirect is clear as has been noted, this contract need not, unless the statute expressly require it, be in writing to be

25 Cornell v. Barney, $94 \mathrm{~N}$. Y. 394; Knapp v. Brown, 45 N. Y. 207; Muldoon v. Pitt, 54 N. Y. 269; Entenman v. Anderson, I06 N. Y. A. D. 149; Meyers v. Daly, 7 Daly (N. Y.) 47I ; Belding v. Cushing, I Gray (Mass.) 576; Simpson v. Dalrymple, II Cushing (Mass.) 308; Herell v. Donovan, 7 App. Cases (D. C.) 322; General Supply Co. v. Hunn, I26 Ga. 6I5; Wendt v. Martin, 89 Ill. 139; Coburn v. Stephens, I37
Ind. 683; Webster City, etc., Co. v. Chamberlin, 137 Iowa 7I7; Cole v. Clarke, $85 \mathrm{Me}$. 336; Horn, etc., Co. v. Steelman, 21 $5 \mathrm{~Pa}$. St. I87.

${ }^{26}$ Costello v. Dale, I Hun. (N. Y.) 489; Marshall v. Cohen, II Misc. (N. Y.) 397; Rush v. Able, $90 \mathrm{~Pa}$. St. I53. 27 Foley v. Alger, 4 E. D. Smith (N. Y.) 7I9; 134; Coorsen v. Ziehl, I03 Wis. 381.

28 Perry v. Potashinski, I69 Mass. 35I. 
effective to support a lien. ${ }^{29}$ While in some States, an implied contract was formerly not considered sufficient to support a lien, ${ }^{30}$ yet in other jurisdictions, including New York, the lien has been regularly sustained notwithstanding the fact that the contract has been by implication merely. ${ }^{31}$

29 Mornan v. Carroll, 35 Manchester v. Searle, I2I Mass. Iowa 22; Montandon v. Deas, 4I8.

I4 Ala. 33 .

${ }^{30}$ Rowley v. James, 3I III. 298, but see amendment to laws, same case, note; Parker v. Anthony, 4 Gray (Mass.) 289; but see contra dicta in
31 Muldoon v. Pitt, 54 N. Y. 269; Hazard, etc., Co. v. Loomis, 2 Disney (Ohio) 544; Vail v. Meyer, 7I Ind. I59; Carney Bros. v. Cook, 80 Iowa 747. 


\section{CHAPTER II}

\section{THE LIEN OF THE ARCHITECT}

$\S 80$. Development of Doctrine.-Enough has been said of the history of lien legislation to make clear why it was that under the early statutes, and the early conception of the purposes and effect of lien legislation, an architect could not avail himself of the advantages of a mechanic's lien. Under the modern extension of the lien doctrine, however, an architect has, quite properly and very generally, been considered as coming within the limitations and qualifications laid down by the various State statutes, although there is found a natural and considerable divergence of opinion in the laws of the different States as to the extent of the lien to which he is entitled, and the character of the work required to qualify him as a proper lienor. In New York the statute provides that

"A contractor, subcontractor, laborer or material man who performs labor or furnishes materials for the improvement of real property with the consent or at the request of the owner thereof, or of his agent, contractor or subcontractor, shall have a lien for the principal and interest of the value or the agreed price, of such labor or materials upon the real property improved or to be improved and upon such improvement, from the time of filing a notice of such lien as prescribed in this article." 1

1 Sec. 3, Article 2, New York Lien Law. 
The courts in construing the language of the section quoted have been liberal in interpreting the meaning of the term laborer, as there applied, and have held that this term applies to skilled, as well as to unskilled, labor, and includes the professional services of architects. ${ }^{2}$

As early as January, 1879, the Court of Appeals of New York, in a case arising under a mechanic's lien law of i 862, and already referred to, stated that:

"The general principle upon which the lien laws proceed, is that any person who has contributed by his labor, or by furnishing materials to a structure erected by an owner upon his premises, shall have a claim upon the property for his compensation.

"The dealer who furnishes the paints and oils, the ordinary workman who applies them or the artist who uses his skill and taste in executing a mural painting, are alike protected by the act. And an architect who makes the plans and supervises the erection of a building is within the words and reason of the law." ${ }^{3}$

\$81. Importance of Superintendence.-The decisions in the various States bearing upon the right of the architect to the benefits of the lien laws vary considerably, according, largely, to the tendencies of the various jurisdictions in regard to lien legislation. But there is one very general element which will be found to exist in the ma-

2 Rinn v. Electrical Power Co., 3 N. Y. A. D. 305 ; Thomson-Starrett Co. v. Brooklyn Heights Realty Co., 111 N. Y. A. D. 358; Stryker v. Cassidy,
$76 \mathrm{~N}$. Y. 50, reversing 10 Hun. (N. Y.) 18.

${ }^{3}$ Stryker v. Cassidy, $76 \mathrm{~N}$. Y. 50, supra. 
jority of the cases where liens have been allowed, and that is the element of superintendence. In a great number of cases decided in New York, New Jersey, Pennsylvania, and in the Federal jurisdiction this element is found in each instance. ${ }^{4}$ In all of the cases last cited the lien of the architect was upheld, but in all, as noted, the element of superintendence was present. In some instances an exception to the general rule has been applied and the lien of the architect has been allowed where superintendence was lacking ${ }^{5}$ but again, even where the architect has prepared plans and specifications and given general directions to the builder, where it appears that the building has been erected under the special superintendence of the builder, a lien has been refused. ${ }^{6}$ Where there occurs a change of ownership of the property in connection with which the work is done, and it is agreed by the new owner that certain additional work shall be done under the supervision of the architect of the building, the lat-

4 Hubert v. Aitken, I5 Daly (N. Y.) 237; Stryker v. Cassidy, 76 N. Y. 50; and see Gurney v. Atlantic, etc., Co., 58 N. Y. 358, distinguishing Ericsson v. Browne, 38 Barb. (N. Y.) 390; Mutual Benefit, etc., Co. v. Rowand, 26 N. J. Eq. 389, reversed on other grounds, I2 C. E. Green (N. J.) 604. Bank of Penn. v. Gries, $35 \mathrm{~Pa}$. St. 423; Phoenix Furniture, etc., Co. v. Put-In Bay Hotel Co., 66 Fed. 683; Johnson v. McClure, io N. M.
506; Arnoldi v. Gouin, 22 Grant's Chan. (Ontario) 3I4; Taylor v. Gilsdorff, 74 Ill. 354; Knight v. Norris, I3 Minn. 473; Friedlander v. Taintor, I4 N. D. (104 N. W. 527), 393; Field v. Consolidated Water Co., 25 R. I. 319; Von Dorn v. Mengedoht, 4I Neb. 525 ; Mulligan v. Mulligan, 18 La. Ann, 21.

- Freeman v. Rinaker, 185 III. I72; Henry, etc., Co. v. Halter, 58 Neb. 685.

6 Raeder v. Pensberg, $6 \mathrm{Mo}$. App. 445. 
ter having given his services to this work, is rightly held to be entitled to a lien, irrespective of the transfer of title to the building. ${ }^{7}$

§ 82. The New York Doctrine.-In New York it has been definitely determined that the architect is not entitled to a mechanic's lien for the preparation and furnishing of plans and specifications, unless, in addition, he superintend the work done thereunder. ${ }^{8}$ Where, however, the architect does superintend the work, done pursuant to the plans and specifications which he has prepared, it is now the clearly established doctrine of the New York courts that he will be allowed to recover, not merely for the work done in his capacity as superintendent, but for the preparation of the plans and specifications as well. ${ }^{\circ}$ For his disbursements

7 Libbey v. Tidden, I92 Mass. 175 .

8 Swasey v. Granite, etc., Co., 158 N. Y. A. D. 549; Rinn v. Electric Power Co., 3 App. Div. (N. Y.) 305, distinguishing Stryker v. Cassidy, 76 N. Y. 50, which in turn distinguished Aitken v. Wasson, 24 N. Y. 482, and Coffin v. Reynolds, 37 N. Y. 640, and reversed Stryker v. Cassidy in the court below, Io Hun. (N.Y.) I8; Aimes v. Dyer, 4I Me. 397, where an architect sued for the value of work performed in preparing a set of moulds for the construction of a ship, and for materials used in such construction, and the court held that under the Maine statute allowing a lien for materials furnished and labor performed, a prepared plan of a house, or a model of a ship, or a mould by which the ship's timbers were to be formed, did not enter into the structure in such manner that they could be regarded as falling within the terms of the statute-and see Bank v. Gries, 35 Pa. St. 423.

${ }^{9}$ Embury v. 42 d St. \& Madison Ave. Co. et al., N. Y. L. J. April I6th, I9r5; Spannhake v. Mountain Construction Co. et al., I59 A. D. (N. Y.) 727 ; and see Swasey v. Granite, etc., Co., I58 A. D. (N. Y.) 549, supra. 
and expenses incidental to superintendence the architect may recover in full. ${ }^{10}$

Where plans and specifications for a proposed building are prepared, and these preliminary plans are thereafter abandoned and the building erected pursuant to other plans and specifications, no lien will attach for the preparation of the abandoned plans and specifications. ${ }^{11}$

$\S 83$. The Massachusetts Doctrine.-One of the clearest expositions of the doctrine that while the architect may have a lien for labor performed by him in supervising the erection of a building, yet his lien will not extend to labor performed in the preparation of plans and specifications, is to be found in the opinion of former Chief Justice Knowlton of the Massachusetts Supreme Court, delivered when he was an Associate Justice of that court, of which Mr. Justice Holmes, now of the Supreme Court of the United States, was likewise at that time a member. The Massachusetts statute provided that a lien might be had for "labor performed or furnished . . . and actually used in the erection" of the building, and Judge Knowlton said:

"The questions presented by this case are, first, whether an architect, who has drawn plans and prepared specifications for the construction of five houses under a contract to draw the plans and specifications and supervise the construction of the houses, and who has supervised the construction of one of the houses until it was about ${ }^{10}$ Rinn v. Electric etc., Co., ${ }^{11}$ Buckingham v. Flummer3 A. D. (N. Y.) 305, supra. felt, I5 N. Dak. II2. 
half completed, and supervised the work of putting in the foundations of two of the others, involving an expenditure of about forty dollars upon one and about fifteen dollars upon the other, can have a lien under the Pub. Sts. c. 19I, for the whole amount due him; and secondly, if he can not, whether he can have a lien for the value of his services in supervising the work upon the buildings, considered apart from the preparation of the plans and specifications.

"The Statutes of the different States in regard to mechanics liens differ materially in their provisions, and the cases show a considerable conflict of authority upon the questions before us. But we are of opinion that, under statutes similar to ours, the weight of judicial opinion is in favor of holding that the services of an architect in preparing plans and specifications for a building are not the kind of labor intended to be protected by the statute, and, on the other hand, that services upon a building in supervising the work of construction enters directly into the construction so as fairly to be called 'labor performed or furnished .... and actually used in the erection' of a building, within the meaning of these words in $\S$ I of the Statute above cited. It is also generally held that the fact that one who does such work is an architect does not prevent him from recovering for this kind of service, which is often performed by an intelligent mechanic. This is the doctrine of the highest court in Pennsylvania, where the provisions of the statute are similar to ours. (Price v. Kirk, 90 Penn. St. 47; Rush v. Able, 90 Penn. St. I 53; Bank of Pennsylvania v. Gries, 35 Penn. St. 423.) Under a like statute in Missouri, it was held in Raeder $v$. Bensberg, 6 Mo. App. 445, that the services of an architect 'in drawing plans and specifica. tions and giving directions to the builder under whose special superintendence the house is being erected, can not be called, in any proper sense of the words, "work or labor upon the building." , A similar decision was made 
in Foushee v. Grigsby, I2 Bush (Ky.) 75; Ames v. Dyer, 4I Maine 397, was a case arising under a statute giving a lien for labor performed and materials furnished 'for or on account of any vessel building or standing on the stocks,' etc., and the attempt was to establish a lien for a mould constructed and used to form the timbers for a ship. The Court said that 'the plan of a house, the model of a ship, the moulds by which its timbers are to be hewed, may be necessary and even indispensable, but they do not enter into any structure so as to be a part of its materials, and cannot be regarded as within the proviso of the statute.' ...

"The preparation of plans and specifications is a preliminary to the construction of a building, and is often merely tentative. It may or may not be followed by a construction according to the plans. It is seldom that either the external or internal form of a building is determined upon, or that its identity is anything more than an indefinite mental conception until after the plans have been completed. We are of opinion that this professional work of the architect, in bringing into existence the definite form and conception of a building which may be erected if the landowner adopts the plan, is not labor performed or furnished.... and actually used in the erection' of a building within the meaning of our statute.

"We are of opinion that the work of supervision which is done directly upon the building, and which is partly physical, but in its more important part mental, may be the subject of a lien under our statute, even if done by the same person who prepared the plans as an architect." 12

As a logical development of the Massachusetts doctrine it is further held in that State that, where the contract is entire and not separable, and the amount due to the architect for services rendered

12 Mitchell v. Packard, I68 Mass. 467. 
in the supervision of the work, as distinguished from services rendered in the preparation of plans and specifications, can not be determined, a lien even for the work of supervision will be refused. ${ }^{13}$

$\S 84$. The Doctrines Contrasted-Discussion. -While the New York and Massachusetts doctrines have been developed under statutes which vary in their provisions and phraseology, and while under the Massachusetts statutes the rule laid down by the courts of that State may be taken as legally correct, the broader interpretation made possible by the provisions of the New York statutes, and by the interpretation thereof by the New York courts, seems certainly entirely proper and equitable. It is difficult to understand why an architect who has devoted his best effort and many hours of his time to the preparation of plans and specifications, and who has superintended the work, should not be allowed adequate protection under the lien laws, while that protection is accorded to the ordinary contractor or material man. The plans and specifications of the architect, in a very real sense, enter into and make possible, the improvement of the property. As a matter of good sense and of equity, it would indeed seem that he should ultimately be accorded a lien for the preparation of plans and specifications irrespective of whether he has superintended the work or not, provided that the work has been carried out in accordance with his plans and in

${ }^{13}$ Libbey et al. v. Tidden et al., I92 Mass. I75. 
accordance with the specifications prepared by him.

§ 85. Reference to Particular Statute Essential. -It must be borne in mind always that the allowance or non-allowance of the lien is based primarily and fundamentally on the language of the particular statute involved. Under some statutes a lien may be allowed for work and materials only; under others, the statute may include alterations; and yet others may specify that the lien is allowed for the erection of the building. In New Jersey, for instance, a lien has been refused for a mere alteration, ${ }^{14}$ but has been allowed for an addition to a building, ${ }^{15}$ while in New York the courts inquire primarily whether or not the improvements have become a part of, and incorporated in, the property; if they have, the mere fact that they are designed for special purposes, such as their use in outfitting the premises for the business purposes of the tenant, does not affect the right to the lien. ${ }^{16}$

\$ 86. Lien by Contract.-While it is true, as has been noted, that the lien is purely a creature of statute and dependent upon the statute, the owner may yet create mechanic's lien rights, or perhaps, more exactly speaking, rights of a character similar to a mechanic's lien, by contract, between him and the architect, or other person furnishing the labor or material. I say that it is

14 Updike v. Skillman, $27 \mathrm{~N}$. J. L. I3I, holding the addition of an extra story to a building an alteration merely.
15 Updike v. Skillman, $27 \mathrm{~N}$.

J. L. r3I, supra.

16 Mosher v. Lewis, 10 N. Y. Misc. 373 . 
more exact to speak of these rights, when created thus by contract, as rights similar to mechanics' lien rights, for the reason that the true mechanic's lien is always a creature of statutory enactment, rather than of private contract or agreement. ${ }^{\mathbf{1 7}}$

\$87. Lighting Fixtures.-The law was somewhat slow in recognizing the right to a lien for lighting fixtures as distinguished from improvements more strictly permanent, for the reason that lighting fixtures are, ordinarily, of such character that they may be easily separated from the realty proper, and were not, therefore, at first, nor until comparatively recently, considered proper bases for a mechanic's lien. Gradually the strictness of the rule in this connection was relaxed, however, and a determination finally established, that in the case of specially designed electric lighting fixtures applicable to a special purpose and especially made to harmonize with, or become a definite and important part of, the structure proper, a lien would be allowed. ${ }^{18}$

The New York Legislature in I9I4 took the last radical step in the development of the lien doctrine in the matter of lighting fixtures by specifically providing, that a lien might be had for services rendered in furnishing and installing electric lighting fixtures. In making this provision, the statute made no distinction between specially de-

17 Lippincott v. Yorke, 86 Tex. 276.

18 Wahle, etc., Co. v. 59th St. \& Madison Ave. Co., I53 N. Y.
A. D. I7; Embury v. 42 d St. 8 Madison Ave. Co. et al., N. $Y$. Law Journal, April I6th, I9r5. 
signed and ordinary fixtures and as the law now stands, therefore, this distinction has been abolished and a lien may be had for the manufacture and installation of fixtures generally. The terms of the amendment are as follows, the portion italicized being the matter added by the amendment of I9I4:

"Improvement. The term improvement, when used in this chapter, includes the erection, alteration or repair of any structure upon, connected with, or beneath the surface of, any real property and any work done upon such property, or materials furnished for its permanent improvement, and shall also include any work done or materials furnished in equipping any such structure with any chandeliers, brackets or other fixtures or apparatus for supplying gas or electric-light." 10

$\S 88$. Consent of Owner.-By reason especially of the modern development of apartments, office buildings and similar properties, the importance of the right to a lien, where the work has been done for a tenant and not merely for the owner direct, has been emphasized more and more of recent years.

Where the work is done at the request of a tenant, the lien may be enforced, if it be shown that the owner has consented to and approved the doing of the work in the expectation that he will derive benefit therefrom, ${ }^{20}$ and this irrespective of whether there is or is not a direct contract relationship between the owner and the contractor.

19 New York Laws, 1914, ch. 506.
20 Kerwin v. Post, 120 N. Y.

A. D. 179. 
This doctrine proceeds

"upon the idea that he who furnishes materials for or does labor upon a building should be reimbursed to some just extent out of the improvement, of which the owner gets the benefit, ... All that the Statute requires as the condition of the lienor's right to such reimbursement is that the labor shall be done upon or the material furnished for the building in process of construction, with the assent of the owner or of the contractors." 21

If it be shown that the owner did not consent to the work being done, but that, on the contrary, the work was contracted for by the lessee entirely on his own account and after the owner had specifically refused to bear any of the expense thereof, the lien will not be enforced. ${ }^{22}$

The consent of the owner need not, necessarily, be express, but may be implied, as well. If he approve the work and receive the benefit accruing therefrom, he will be held to have impliedly consented that it be done. He can not stand idle and allow the work to be done and the benefit thereof to accrue to his property and then turn about and attempt to defeat the lien by the plea that his consent has not been given. ${ }^{23}$ Stating substantially the same rule, in slightly different phraseology, it has been said that the lien statute in New York "proceeds upon the equitable principle that one who knowingly receives the benefit of the labor or

21 Pell v. Baur, 133 N. Y. 377.

$22 \mathrm{McNulty}$ v. Offerman, I64

N. Y. A. D. 949.
23 National Wall-paper Co. v. Sire, 163 N. Y. 122; and see Otis v. Dodd, 90 N. Y. 336. 
property of another in the form of improvements upon his land, ought to have his property subjected to a lien for the value of such improvements." 24

24 Butler v. Flynn, 5I N. Y. A. D. 225; and see also Nellis v. Bellinger, 6 Hun. N. Y. 560. 


\section{CHAPTER III}

\section{THE LIEN OF THE CONTRACTOR}

$\S 89$. Classes of Lienors.-In considering the right of the contractor, or subcontractor, or material man, or mechanic, to a lien, it must, imprimis, be recognized that there is a clear distinction in the lien laws between these various classes. The rule has been stated to be that if the claimant's "charge is for materials alone, then he is a material man; if his charge is for work and labor in putting the materials in the building, then he is a contractor for the erection of the building;" ${ }^{1}$ but this rule has later been held too narrow, in that one furnishing and placing in the building materials in finished form should be allowed to claim as a material man just as readily as one furnishing raw materials alone. ${ }^{2}$

Where the contract under which the lien is claimed is a direct contract between the owner and the lien claimant, and involves not only the furnishing of materials but their installation or incorporation in the building as well, the question of whether the person between whom and the owner the contract is made, shall be considered the original contractor or material man, is largely

1 Vice Chancellor Stevenson, 2 Beckhard v. Rudolph, $68 \mathrm{~N}$. in Beckhard v. Rudolph, $68 \mathrm{~N}$. J. Eq. 740, reversing $68 \mathrm{~N}$. J. J. Eq. 315. 
determined by the fact of whether or not the labor bestowed upon the materials in installing or in incorporating them in the building, is comparatively insignificant or considerable, in comparison with the price of the materials so installed. ${ }^{3}$ Thus, services consisting of papering and decorating rooms have been said to be the services of the original contractor, ${ }^{4}$ while one furnishing an electrical plant ${ }^{5}$ or one furnishing a steam plant, ${ }^{6}$ has been considered a material man.

To qualify as a contractor within the meaning of the lien laws it is not necessary that one be the holder of a contract for the entire work under way or contemplated; the owner may, as is entirely usual, enter into separate agreements with a number of different contractors, covering different phases of the work. ${ }^{7}$ Under the more conservative statutes, and in the earlier development of the lien law, the contractor was held to be not entitled to lien rights, for the reason that he could not be classed as a material man; but the right of the contractor to lien protection is now very generally recognized, and this in the very jurisdictions where previously a more restricted doctrine was adopted. ${ }^{8}$

3 Bennett v. Davis, I I3 Cal. an electrical plant a contractor. 337.

4 LaGrill v. Mallard, 90 Cal. 373.

' Hinckley v. Fields, etc., Co., 9r Cal. r36.

7 Duff v. Hoffmann, $63 \mathrm{~Pa}$.

'Roebling's Sons' Co. v. St. I92; Schenck v. Uber, 81 Humboldt, etc., Co., Ir2 Cal. Pa. St. 3I ; Pacific Mutual, etc., 288-compare, Salem v. Lane, etc., Co., I89 Ill. 593, holding one furnishing an engine for

Co. v. Fisher, 106 Cal. 224.

8 Chapman v. Faith, I8 $\mathrm{Pa}$. Super. Ct. 578; Lester v. 
§90. Various Statutory Provisions.-In the case of the contractor, as in the case of the architect, the special provisions of the statutes in each jurisdiction must be considered, in determining whether the services performed are such as are recognized as the proper basis for a lien. In Illinois, work done in ornamenting a house comes within the statute. ${ }^{9}$ In California, under an act recognizing improvements as the basis of a lien, papering and decorating have been considered as constituting improvements. ${ }^{10}$ In Massachusetts, the installing of a drying machine in a glue and chemical manufacturing plant has been construed as embodying merely slight changes, incidental to work on personal property, and as not therefore properly the basis of a lien. ${ }^{11}$

§ 91. Performance Must Be Proven.-It is almost self-evident that the contractor, if he is to place himself in a position where he may claim the protection of, or advantage accruing from, the statutory lien accorded him, must perform his contract, or show that he has been prevented from performing by the acts of the other party, or that the unperformed provisions of the contract have been waived. $^{12}$

Houston, ror N. Carolina, 605 ; Bryan v. Whitford, 66 Ill. 33 -for erecting and repairing; Powell v. Nolan, 27 Washington 318; Haines v. Holland (I898, Tenn. Ch. App.), $48 \mathrm{~S}$. W. 400; compare also Winder v. Caldwell, I4 How. U. S. 434, decided under U. S.
Statute of 1833 and refusing lien.

${ }^{9}$ Drew v. Mason, 8I Ill. 498. $10 \mathrm{La}$ Grille v. Mallard, 90 Cal. 373 .

11 Curnew v. Lee, 143 Mass. I05.

12 Woolf v. Schaefer, $103 \mathrm{~N}$. Y. A. D. 567, reversing $4 \mathrm{I}$ 
§92. Substantial Performance SufficientStatement of the Rule.-That performance of the contract which is considered as necessary under this rule has been construed, as between the owner and the principal contractor at least, to be a substantial performance, and if the contract has been substantially performed, within the meaning of that term as interpreted by the courts, a lien may be enforced. ${ }^{13}$

\section{The rule has been well stated to be that}

"If there has been no wilful departure from the terms of the contract, or omission in essential parts, and the laborer has honestly and faithfully performed the contract in all its material and substantial features, he will not be held to have forfeited his right to remuneration by reason of mere technical, inadvertent and unimportant omissions or defects. The law imposes no such liability upon and exacts no such penalties of the mechanic." ${ }^{14}$

Misc. N. Y. 640; Mahon v. Guilfoyle, I8 N. Y. Supp. 93; Smith v. Ruggiero, 52 A. D. (N. Y.) 382; Trust Co. v. Guigues, 76 N. J. Eq. 495; Smith v. Coe, 2 Hilt (N. Y.) 365 , affirmed 29 N. Y. 666; May v. Menton, 18 Misc. (N. Y.) 737 ; Derr v. Kearney, 46 Misc. (N. Y.) I48; Rochford v. Rochford, 192 Mass. 23I ; Pritzlaff, etc., Co. v. Berghoefer, I03 Wis. 359; Bohem v. Seabury, I4I Pa. St. 594; Morrison Co. v. Williams, 200 Mass. 406; Burke v. Coyne, I88 Mass. 40I; Frohlich v. Klein, 160 Mich. 142; Kane v. Stone Co., 39 Ohio St. I; Malbon v. Birney, II Wis. I07; Brydon v. Lutes, 9 Manitoba 463.
${ }^{13}$ Ruigle v. Wallis Iron Works, 149 N. Y. 439; D. A. Tompkins Co. v. Monticello, etc., Co., I37 Fed. 625; Brandt v. City of New York, IIo N. Y. A. D. 396 , affirmed $186 \mathrm{~N}$. Y. 599; Felgenhauer v. Haas, 123 A. D. (N. Y.) 75 ; Nesbit v. Braker, I04 A. D. (N. Y.) 393; Sinclair v. Tallmadge, 35 Barb. (N. Y.) 602 ; Moore v. Dugan, I79 Mass. 153; Bergfors v. ICaron, I90 Mass. I68; Burke v. Coyne, 188 Mass. 40I ; Sherry v. Madler, I23 Wis. 62I; Kane v. Stone Co., 39 Ohio St. I.

14 Allen J. in Sinclair v. Tallmadge, 35 Barb. (N. Y.) 602, at p. 604. See also on interpretation of substantial perform- 
$\S 93$. Effect of Delay.-A delay by the contractor in carrying out the contract will not prevent him from enforcing his lien rights where the contract has been carried out, although late; but damages for the delay will be deducted from the contract price. ${ }^{15}$

$\S 94$. Limitation of Rule.-The foregoing rule is subject to the qualification that where time is stipulated to be of the essence of the contract, that is to say, a fundamental term of the contract, a breach by the contractor of this fundamental provision, by tardiness in the completion of the work, will prevent him enforcing his rights as a lienor. ${ }^{16}$

$\S 95$. Necessity of Architect's Approval.Where it is provided, as is so usually done, that the work of the contractor must be approved in due course by the architect, and that the certificate of the architect must be presented as a condition precedent to payment, the contractor can enforce no lien without either the presentation of the required certificate, or proof of a proper excuse for not presenting it. ${ }^{17}$ Where the plaintiff does not produce the certificate specified and relies upon proof that the certificate has been demanded and

ance, Glacius v. Black, $50 \mathrm{~N}$. Y. I45; Otis Elevator Co. v. Dusenbury, 47 Misc. (N. Y.) 450; Holl v. Long, 34 Misc. (N. Y.) I ; Wollreich v. Fettretch, 4 N. Y. Supp. 326.

15 Benner v. Schmidt, 44 Ill. App. 304.

${ }^{16} \mathrm{D}$. A. Tompkins Co. v.
Monticello Co., I37 Fed. 625. 17 Thomson-Starrett Co. v. Brooklyn Hts. Realty Co., III N. Y. A. D. 358; Nesbit v. Braker, I04 N. Y. A. D. 393; Highton v. Dessau, I39 N. Y. 607 , affirming i9 N. Y. Sup. 395; Bloominton Hotel Co. v. Garthwait, 227 Ill. 613. 
its delivery by the architect refused, the burden of proof is upon the plaintiff to establish these facts by a preponderance of evidence in his favor and to establish in the same way, and as part of his case, the fact that the certificate was unreasonably withheld. ${ }^{18}$

It should be noted, also, that in New York it has been held, where the production of the architect's certificate is made a condition precedent to the right of payment, not only that there can be no recovery unless the certificate be produced, or a good and sufficient excuse shown for its non-production, but, in addition, that no payment can be enforced under these circumstances unless there be an allegation in the complaint that the certificate has been secured, or facts set forth showing that it has been unreasonably withheld, and unless the pleading be sustained by proof upon the trial. ${ }^{19}$

§ 96. Municipal Contract-Approval by City Department as Condition Precedent.-In the case of a municipal contract where it is stipulated that the certificate of approval of a department of the city is a condition precedent to final payment, and the claim is made that the certificate has been unreasonably withheld or refused, whether or not such withholding or refusal has been unreasonable or arbitrary is a question of fact, and should be left to the jury for determination. ${ }^{20}$ In this connection it is perhaps interesting to note that

18 Nesbit v. Braker, 104 N. throp, 59 A. D. (N. Y.) 192. Y. A. D. 393 .

${ }^{20}$ N. Y. \& N. H. Automatic ${ }^{19}$ Weeks v. O'Brien, I4I N. Sprinkler Co. v. Andrews, I73 Y. 199; L'Hommedieu v. Win- N. Y. 25. 
Section 421 of the Greater New York Charter provides among other things that:

"It shall be the duty of any borough president, or head of any department, having in charge any work, within five days after the acceptance of such work, to file with the comptroller a final certificate of the completion and acceptance thereof, signed by the chief engineer or head of his department. The filing of such certificate shall be presumptive evidence that such work has been completed according to contract."

§97. Collusion-Effect.-Where the withholding of the certificate is the result of collusion between the architect and the owner, the lien will be enforced. ${ }^{21}$

$\S 98$. Waiver of Condition by Owner.-Inasmuch as the production of the certificate is a condition specified for the protection of the owner, the latter may waive the condition if he choose to do so. ${ }^{22}$

$\S 99$. Certificate as Evidence of Performance. - The certificate of the architect will support the lien claim where the contract specifies that the certificate shall be conclusive evidence of performance, but this rule is subject to the qualification that it is operative only in cases where the certificate is not only produced but is unimpeached. If it be provided, for instance, that the work to be done and materials to be furnished shall be of a

$21 \mathrm{McDonald}$ v. Patterson \& Co., I86 Ill. 38I, affirming 84 I11. Apps. 326 .
22 Hartley v. Murtha, $5 \mathrm{~N}$.

Y. A. D. 408. 
certain character and quality, and subject to acceptance or rejection by the architect, his acceptance will not in itself be sufficient to support the lien claim, where it is shown that the work and materials are not of such character and quality as to comply substantially with the provisions of the contract.

$\S$ I00. Corporations as Lienors.-The mere fact that the contractor claiming the lien is a corporation, will ordinarily under the lien statutes make no difference, for the word "person" commonly and widely used in the statutes in describing those who are entitled to liens, has been construed by the courts, in the absence of other restrictive language, to include a corporation. ${ }^{23}$ The New York courts have held further that where a foreign corporation delivers material which is used in work in New York a lien may be maintained by the corporation notwithstanding its foreign origin. ${ }^{24}$

$\S$ IOI. Effect of Fire.-In the event of the destruction of a building by fire where it has been provided that payment shall be made upon completion and where the contract is not separable, but refers to the work as a whole, a lien may be maintained, provided the contract contain a provision

${ }^{28}$ Gaskell v. Beard, 58 Hun. (N. Y.) Ior ; Loudon v. Coleman, $59 \mathrm{Ga}$. 653 .

24 N. Y., etc., Terra Cotta Co. v. Williams, 102 N. Y. A. D. I; and to same effect see Cook v. Rome Brick Co., 98 Ala. 409; Fagan v. Boyle, etc., Co., 65 Texas 324; Huttig Bros., etc., Co. v. Denny Hotel Co., 6 Wash. I22. 
that the risk of the destruction of the building by fire is upon the owner. ${ }^{25}$ In the absence of such a provision however, the lien will not be enforcible. ${ }^{26}$

$\S$ ro2. Change in Ownership.-Where a lien has once attached, a mere change in ownership in the building during the progress of the work does not constitute a new commencement of building operations and does not affect the lien already attached. ${ }^{27}$

$\S$ ro3. Death of Owner.-In the event of the death of the owner, the death operates, in some jurisdictions, to defeat the lien right, ${ }^{28}$ while in others the lien may still be enforced. ${ }^{29}$

$\S$ 104. General Assignment.-The right to a lien has been held to be unaffected by an assignment for the benefit of creditors where the assignment is subsequent to the filing of the lien; ${ }^{30}$ and in Ohio, even where the assignment has preceded the filing of the lien the continuing validity of the latter has been recognized. ${ }^{31}$

$\S 105$. Consent of the Owner.-The facts already noted under another heading ${ }^{32}$ in regard to

${ }^{25}$ Sontag v. Brennan, 75 Ill. Appeal, 102 Pa. St. 218. 279. 29 Robins v. Bunn, 34 N. J.

${ }^{26}$ Wigton's Appeal, $28 \mathrm{~Pa}$. L. 322 ; Holbrook v. Ives, 44 St. I6r. Ohio St. 516; Richardson v. ${ }^{27}$ Pennock v. Hooper, 5 Hickman, 32 Ark. 406.

Rawle (Pa.) 290; Gordon v. Torrey, 15 N. J. Eq. II2.

${ }^{28}$ Tubridy v. Wright, $144 \mathrm{~N}$. Y. 519, affirming 7 Misc. N. Y. 403; Crystal v. Flannelly, 2 E. D. Smith N. Y. 583; Hoff's ${ }^{30}$ Steger v. Arctic Refrigerating Co., 89 Tenn. 453. 31 Hart v. Globe Iron Works, 37 Ohio St. 75-compare, Noyes v. Burton, 29 Barb. N. Y. 63 r. 32 See $\$ 88$, p. 157 . 
the necessity and effect of the owner's consent are applicable also to the lien of the contractor or sub. contractor, or other similar lienors. 


\section{CHAPTER IV}

\section{THE LIEN OF THE SUBCONTRACTOR}

$\S$ 106. Nature of Lien.-The natural effect of the extension of the lien doctrine has been to protect the subcontractor as well as the contractor, and in many cases the subcontractor has been given a direct or subordinate lien by statute. ${ }^{1}$

$\S$ I07. The Pennsylvania Doctrine.-The Pennsylvania courts especially have led in the movement to give the subcontractor a direct lien on the property irrespective of the rights of the contractor. $^{2}$

$\S$ 108. The New York Doctrine.-In New York State the courts have not adopted the idea of a direct lien for the subcontractor, but have

1 Pendleburg v. Meade, I E. statute) that a lien in favor of D. Smith N. Y. 728; Perry v. a subcontractor for labor is inPotashinski, I69 Mass. 35I; clusive of the labor of his Merrigan v. English, 9 Mon. employees, but not of materials I13; Ballon v. Black, 21 Neb. furnished by him; Knowiton v. I3I ; Berger v. Turnblad, 98 Ellis, I2 Phil. (Pa.) 396; HutMinn. 163; Vaughan v. Ford, tig, etc., Co. v. Denny Hotel I62 Mich. 37; Green v. Wil- Co., 6 Washington I22.

liams, 92 Tenn. 220; Central 2 Linden Steel Co. v. Rough Trust Co. v. Richmond, etc., Run Manufacturing Co., ${ }_{5} 8$ Co., 68 Fed. 90; Crane Co. v. Pa. St. 238; Willey v. Topping, Hanley, etc, Co., 53 Mo. Ap- 146 Pa. St. 427; White v. peals 540; Seaman v. Bie- Miller, $18 \mathrm{~Pa}$. St. 52 ; but commann, I08 Wis. 365 ; Hatch v. pare Schroeder v. Galland, I34 Fansher, I5 R. I. 459, also holding (under the Rhode Island 
given him a lien based upon the doctrine of, or more exactly speaking in the nature of, subrogation, and, as a condition precedent to awarding any lien to the subcontractor, require that the contractor himself shall be entitled to a lien, and that in any event there shall be monies due from the owner to the contractor to which the subcontractor may be subrogated. ${ }^{3}$

Under the subrogation doctrine as exemplified in the New York cases, the owner is afforded a protection which is not given him under the doctrine of a direct lien for the subcontractor as exemplified in the Pennsylvania cases. Thus, under the New York doctrine, where the principal contractor fails to complete, while the right of the subcontractor to his lien is not affected, the extent to which the lien can be enforced is very materially affected, in that, under these circumstances, the New York courts will allow the subcontractor to enforce his lien to the extent merely of the amount due to the contractor from the owner at the time when the lien is filed, or at the time when the subcontractor gives proper notice of his claim. ${ }^{4}$

Applying the New York doctrine to the usual provision in a building contract which provides

${ }^{3}$ LaPasta v. Weil, 20 Misc. (N. Y.) 554, reversing 20 Misc. (N. Y.) ro; Kirschner v. Mahoney, 96 N. Y. Supp. I95; and see, contrasting Pennsylvania doctrine of direct lien and New York doctrine of subrogation, Prince v. Neal Millard Co., 124 Ga. 892 ; Mer- rigan v. English, 9 Mon. II3; Hunter v. Truckee Lodge, etc., 14 Nev. 24.

4. Foshay v. Robinson, $16 \mathrm{~N}$. Y. Supp. 817 , affirmed $137 \mathrm{~N}$. Y. 134; and to same effect see Wright v. Pohls, 83 Wis. 560; compare N. J. Steel, etc., Co. v. Robinson, 33 Misc. (N. Y.) 361. 
that payment shall be made in installments, on account of the total amount, and that the balance of the stipulated price shall be paid upon completion, the effect is to prevent the subcontractor from enforcing a lien against the balance retained under such a provision, in the event that the contractor fails to complete. ${ }^{5}$ If the owner, however, elects to come in and complete the work under a contract provision allowing him so to do, and does this, shortly before an installment is to fall due to the contractor, a subcontractor or material man may enforce a lien to the extent of the amount of the installment so to become due, less such amount as may be necessary to complete the work to the point when the installment would become due, less also such sum as may be required to make good defective work; and this rule holds true despite the fact that there may be nothing due to the contractor, on the completion of the building, by reason of his failure to complete. ${ }^{6}$

$\S$ rog. Failure of Contractor to Complete.Work done by the subcontractor for the owner, after the abandonment of the contract by the contractor, gives to the subcontractor the right to a lien for the full amount of the value of such work, this being a new undertaking as between himself and the owner, and entirely separate from the work done by him theretofore under his contract

Kelly v. Bloomingdale, I9 N. Y. Supp. I26, affirmed, I39 N. Y. 343 ; Brainard v. County of Kings, 84 Hun. N. Y. 290, affirmed I55 N. Y. 538 .
- Foshay v. Robinson, I6 N. Y. Supp. 8I7, affirmed I37 N.

Y. I34. 
with the main contractor. ${ }^{7}$ If the breach of the contract is on the part of the owner as distinguished from the contractor, and the latter's failure to complete results from such a condition, the lien of the subcontractor may be enforced to the extent of such part of the contract price as may remain unpaid. ${ }^{8}$

$\S$ I Io. Rights of Subcontractor as Affected by Contract.-There is a diversity of opinion among the courts of the different States as to the validity and effect of a provision in a building contract providing that the subcontractor shall not acquire a lien, or providing that the contractor may not, without the owner's consent, sublet his contract. In some jurisdictions it has been held that a lien, being purely statutory, and provided solely by the decree of the Legislature, cannot be interfered with by the provisions of the building contract, and that the subcontractor is accordingly entitled to his lien, irrespective of any covenant which the contractor may have made in this connection with the owner, ${ }^{9}$ while in other jurisdictions the courts have considered that the subcontractor is charge-

7 Delray, etc., Co. v. Keohone, 132 Mich. 17.

8 Person v. Stoll, 72 N. Y. A. D. I4I, affirmed I74 N. Y. 548.

Atlantic, etc., Co. v. Donnelly, 59 N. J. L. 48 ; see also Huttig, etc., Co. v. Denny Hotel Co., 6 Washington 122; and that a subcontractor is entitled to his lien despite a pro- vision that the contractor may not sublet the contract and despite the fact that the owner has not given his consent to the making of the contract between the contractor and the subcontractor, see Wahlstrom v. Trulson, I65 Mass. 429; Perry v. Potashinski, 169 Mass. 351. 
able with notice of the provisions of the building contract and is, accordingly, barred from his lien under such circumstances. ${ }^{10}$

$\S$ III. Employees and Material Men of Subcontractor.-It was a very general rule in the earlier stages of the development of the lien law that the employee of a subcontractor was not entitled to any lien rights. ${ }^{11}$ The same rule was likewise applied to those furnishing materials, ${ }^{12}$ or furnishing labor to the subcontractor. ${ }^{13}$

The stringency of these earlier decisions has been largely modified, however, by statutes and decisions providing in substance for liens in favor of those performing labor or furnishing materials for subcontractors. ${ }^{14}$

10 Dersheimer v. Maloney, I43 Pa. St. 532; Schroeder v. Galland, I34 Pa. St. 277; Seaman v. Biemann, 108 Wis. 365 .

11 Central Trust Co. v. Richmond, etc., Co., 54 Fed. 723; Harlan v. Rand, $27 \mathrm{~Pa}$. St. 511 ; Culver v. Attwood, 170 Ill. 432; Morrison v. Whaley, I6 R. I. 7I5; Farmer v. St. Croix, etc., Co., II7 Wis. 76.

12 Central Trust Co. v. Richmond, etc., Co., 54 Fed. 723; Wood v. Donaldson, I7 Wend. (N. Y.) 550, affirmed 22 Wend. 395; Heroy v. Hendricks, 4 E. D. Smith (N. Y.) 768; Carlisle v. Knapp, 5 I N. J. L. 329; Duff v. Hoffmann, $63 \mathrm{~Pa}$. St. I9I ; Harbeck v. Southwell, I8 Wis. 4I8; Stephens v. United R. R. etc., Co., 29 Ohio St. 227.

13 Central Trust Co. v. Richmond, etc., Co., 54 Fed. 723;
Wood v. Donaldson, I7 Wend. (N. Y.) 550, affirmed 22 Wend. 395 ; Cairo, etc., Co. v. Watson, 85 Ill. 53I; Vandenberg v. P. T. Walton, etc., Co., I9 Okla. 169.

14 Vogel v. Luitwieler, 52 Hun. (N. Y.) I84; Brainard v. County of Kings, 84 Hun. (N. Y.) 290 , affirmed I 55 N. Y. 538; Garrison v. Borio, 6I N. J. Eq. 236, 47 Atl. I060; Gardner, etc., Co. v. N. Y. Central, etc., Co., 72 N. J. L. 257 ; distinguishing Carlisle v. Knapp, 51 N. J. L. 329; Snyder v. N. Y. Central, etc., Co., 72 N. J. L. 262 ; Smith v. Neubaur, I44 Ind. 95; Barlow Bros. Co. v. Gaffney, 76 Conn. I07; Macomber v. Bigelow, 126 Cal. 9 ; Pere Marquette R. Co. v. Baertz, 36 Ind. Apps. 408. 
§ I 12. Necessity and Effect of Filing or Recording Contract.-There are statutory provisions in a number of the States with reference to the filing or recording of the contract between the owner and the contractor, and while discussion of these might properly be included under the separate discussion to be given to the construction contract, their effect on the lien rights of the parties is such that it seems preferable that they be considered in the present connection.

In some States these statutes have taken the form of providing that no lien can be predicated upon the contract unless the latter is in writing and recorded; ${ }^{15}$ while in others only contracts in excess of specified amounts need be so recorded. ${ }^{16}$ In California the rule has been modified, by a determination that a filing of a memorandum of the contract, embracing copies of substantially all topics required to be filed by statute, is sufficient. ${ }^{17}$ In New Jersey a very different situation is found in that, under the New Jersey Laws, in the event that the contract is in writing and is filed, with the specifications, with the clerk of the county where the work is done, at or before the time when the building is begun, the liability of the owner is thereby limited to the contractor only, and does not extend to those performing services or labor

15 McClallan v. Smith, II Cush. (Mass.) 238; Conner v. Lewis, 16 Me. 268; Iaege v. Bossieux, 15 Grat (Va.) 83; compare, Nolte v. His Creditors, 6 Mart. (N. S.) La. I68.
16 Smith v. Bradbury, 148 Cal. 4I; Whitla v. Taylor, 6 La. Ann. 480 .

17 Blinn Lumber Co. v. Walker, 129 Cal. 62. 
or providing materials for the contractor. ${ }^{18} \mathrm{It}$ should not be understood from this rule, however, that the subcontractor or material man is helpless by reason thereof. It prevents him merely from enforcing a lien under the circumstances noted, but it does not prevent him securing a very definite degree of protection by the filing, under the New Jersey law, of what is commonly known as a "Stop Notice," which is, in substance, a notice to the owner of his claim. The effect of this is to place the owner in a position where the payment by him of additional monies to the contractor will be at his peril in view of the notice which he has received. As a practical matter this course will usually result in the owner's refusing to pay to the contractor such balance as may be due him and withholding it from him, subject to proper proof of the claims of those subcontractors from whon notices have been received.

Formerly in New Jersey the filing of specifications or copies thereof with the contract was not required in every instance. It would appear, however, ${ }^{19}$ that this former rule dispensing with the filing of the specifications was limited largely to those cases where all the work was to be done, and the materials furnished, by the contractor,

18 English v. Warren, 65 N. Budd v. Lucky, 28 N. J. L. J. Eq. 30; La Foucherie v. 484; Ayres v. Revere, 25 N. J. Knutzen, 58 N. J. L. 234; L. 474 ; compare, Glading v. Freedman v. Sandknop, 53 N. Frick, $88 \mathrm{~Pa}$. St. 460.

J. Eq. 243; Weaver v. Atl., ${ }^{19}$ LaFoucherie v. Knutzen, etc., Co., 57 N. J. Eq. 547 ; Wil- 58 N. J. L. 234, supra.

lets v. Earl, 53 N. J. L. 270; 
himself one of the parties to the agreement, and that, even formerly, the necessity existed of filing these specifications in the event that the contract referred to the specifications for the details of the work to be done, or was itself so incomplete that an examination of the specifications became absolutely necessary for a proper understanding of the arrangements which had been made. ${ }^{20}$ The filing of the specifications or a duplicate or copy thereof, according to whether the original contract or a duplicate or copy thereof is filed, is, under the present New Jersey statutes, however, mandatory if the owner is to be protected. ${ }^{21}$

$\S$ I I3. Priority of Claims.-In concluding the present discussion of mechanics' liens it should be again noted, and remembered always, that in every instance the only safe course to follow is to refer directly to the statutes of the particular State in which it is desired to enforce the lien. Only in this way can a definite and adequate understanding be reached of what rule is to be applied under the special circumstances existing, and only so can the various elements of the extent and time of accrual of the lien, the property affected thereby, and the rights of priority of respective lienors, be properly determined. Thus, in New York, section thirteen of the lien law gives to those who have performed labor and furnished materials, priority over the general creditors of

${ }^{20}$ English v. Warren, 65 N. $\quad{ }^{21}$ English v. Warren, $65 \mathrm{~N}$. J. Eq. 30; Weaver v. Atl. Roof- J. Eq. 30, supra. ing Co., 57 N. J. Eq. 547. 
an insolvent owner or contractor, and this section, in connection with sections twenty-five and fiftysix thereof, provides for the priority of day laborers over contractors and subcontractors, irrespective of when their liens are filed, and likewise of a material man over such contractors or subcontractors. ${ }^{22}$ In New York, too, laborers and material men are given priority, among themselves, according to the date of the filing of their respective liens.

The priority of lienors in other jurisdictions will naturally vary, to a greater or less extent, in accordance with the peculiar doctrines or conditions which there exist, and it will not be amiss to emphasize again the fact that, in all instances, the decisions on the various phases of the lien law are based upon the special provisions of the particular statutes involved, and that only by a careful examination of the statutes in force when and where a case arises can the exact rights of the parties be properly weighed and determined.

22 See Herman et al. v. City Proctor, etc., Co., 62 Misc. (N. of New York, I30 N. Y. A. D. Y.) 129.

53I; Hedden Const. Co. v. 


\section{PART IV}

\section{THE ARCHITECT AND THE CON-}

TRACTOR-CONCLUSION 



\section{CHAPTER I}

\section{THE ARCHITECT AND THE CONTRACTOR}

§ I 4. Rights and Liabilities in General.-The relations in general of the architect and the contractor, and their mutual rights and liabilities, closely inter-related as they are with the other phases of the subject, have been already considered in some detail. It is proper to note again, however, that while the architect's primary duty is to the owner, his client, he must nevertheless, and especially in his capacity as arbitrator, be careful that his decisions and the course pursued by him are consistent with fair dealing to the contractor as well. In the matter of the issuance of certificates he should exercise special care, for in this detail the builder is primarily within the power of the architect, under the provisions of the ordinary building contract of to-day. For an improper refusal by the architect to issue a certificate, the issuance of which is essential to the proper protection and enforcement of the rights of the builder, the latter may, it has been indicated by the British courts, hold the architect liable for the damages sustained by reason of his refusal. ${ }^{1}$

${ }^{1}$ Ludbrook v. Barrett, 46 L. J. C. P. 708. 
§ II5. Right to Plans.-With respect to the plans, the builder is not in a position to make the claim of ownership which can be set up by the owner, but at the same time, it seems that there is recognized a right in the builder to use and to hold the plans in his possession, during the time that the building is in course of erection. The courts have gone so far, in one jurisdiction at least, as to hold, under this doctrine, that the builder may maintain an action in trespass against the architect, where the latter has taken the plans from the possession of the builder, without his consent and prior to the completion of the work; and that the taking of the plans by the architect under these circumstances, if done secretly and with felonious intent to convert them to the architect's own uses, and to deprive the builder of the use of them, is ground for a prosecution for larceny. ${ }^{2}$ It will be observed that in the case last cited, the decision on the point of larceny is predicated on the assumption that the plans are taken with felonious intent, which element being assumed or shown naturally leads to the conclusion reached, but the case is interesting nevertheless as illustrative of the fact that care should be exercised not to assume too boldly an ownership of or control over the plans, under any and all circumstances.

2 Lunsford v. Dietrich, 86 Ala. 250. 


\section{CHAPTER II \\ CONCLUSION}

§ I 16. Summary and Final Suggestions.-In closing, it may be well to draw attention by way of brief summary to some of the more important of the points referred to in the foregoing pages, and especially to those points of particular importance to the proper protection of the architect and to the enforcement of his rights.

If the architect is to practice his profession, and deal with his clients, with a minimum of legal controversy or loss, he must, in the first place, see that his contract with his employer is as definite in all of its terms and provisions as it is possible to make it. If his employment is merely for the purpose of preparing preliminary drawings, he should take care that nothing is said from which it can be assumed that he waives his right to payment for the work done; and if possible it should be expressly understood that payment is expected. On the points of agency and extras, especially, the contract and understanding should be full and unequivocal, and as to both of these points the architect should exercise the greatest care in the assumption of any authority not expressly and clearly provided for. He should remember that the building contract is, as to many of its provisions, drawn for the primary protection of his 
client and that, without the consent of the client, he may not safely undertake to waive, or allow the builder to believe that he can waive or dispense with, any of the stipulations which have been made for his client's benefit, such as those requiring written authorization for extra work, the proper completion of work before a certificate is issued therefor, and the presentation of the certificate as a condition precedent to the right to enforce payment.

Not only should the architect make sure that the terms of the contract between his client and himself are clearly understood, in order to avoid the many difficulties which it has been seen an ambiguity or careless wording of the contract may mean to both of them, but he should, in addition, be careful to see that the contract is properly executed and legally binding. This caution applies particularly to those cases where the client is an association or corporation, or one acting in a representative as distinguished from an individual capacity. It ofttimes happens that a contract entered into by or in behalf of a corporation which, to the ordinary layman, would seem to be unquestionably binding on the corporation, is, in fact, not so at all, for the reason that some requisite element or formality well recognized in law, but not of such a nature as to be readily realized by the architect, has been omitted, thus rendering the contract void as against the corporation.

In dealing with corporations, and especially with municipal corporations, therefore, the archi- 
tect should satisfy himself that all proper legal formalities have been complied with, that the contract has been executed by the proper officer and is in the proper form, that due authority has been granted by the directors or the city department or governing bodies of the corporation, as the case may be, wherever such authority is necessary to render the contract binding upon the client, and that the contract is in general, and in all respects, so drawn and so executed that its validity will be upheld, and its terms enforced. Thus, also, in dealing with trustees or executors or those acting in any representative capacity, in matters involving large expense or compensation of real importance, it will not be going too far for the architect to secure, if possible, certified copies of Letters Testamentary and similar documents and, in the case of corporations, copies of directors' minutes, of by-laws or of other papers whereby the authority or other elements upon which the validity of the contract depends may be clearly determined.

The architect must remember, too, that while the law requires nothing unusual in the way of skill and attention in the supervision of the work, on the other hand, it does require that there shall be present a reasonable degree of each; and, as to supervision, he should remember that in order to lay a clear and proper basis for the protection of his rights, under the mechanic's lien statutes in the various jurisdictions, he should, if possible, see that the element of supervision of the work, 
even if to a very slight extent, is present, to comply with the rule pursuant to which so many of the States have granted and enforced a lien, where this element has been established, but refused relief where it has been absent.

Finally, in the matter of plans, if it be desired that title thereto remain in the architect, care should be taken to see that a specific stipulation to this effect is included in the contract or agreement between the architect and the client.

It is of equal importance that the owner and the builder be vigilant to insure that the construction contract between them be clearly understood, and without any latent ambiguity; that any provisions for liquidated damages or extras, especially, be so phrased and determined upon that there can be no doubt in the mind of any one of their meaning, or of the intentions of the parties to the contract; that neither of the parties give to the other any cause for complaint, on the ground of unfair treatment or collusion with the architect, or with other parties; and that any provisions for arbitration in the contract be so drawn that they can not be construed to usurp in any way the jurisdiction or proper province of the courts.

The builder, before he institutes any action against the owner for the recovery of the contract price, should be very sure that he himself has complied with all the terms of the agreement between them; that he is not estopped from recovering the amount which he claims to be due him by a failure to secure the architect's certificate, or to offer a 
proper excuse for its non-production; and that the contract has been performed by him in all substantial particulars, or, in the event that it has not been so performed by him, that performance has been waived or prevented by the owner. The owner, on the other hand, in withholding any payment from the builder, or in attempting to terminate the contract and complete the work, should be satisfied, before he acts, that, as a matter of law, the work has not been properly performed, and that the builder is legally in default; otherwise, by proceeding against the builder or by terminating and completing the contract himself, he may thereby incur a personal liability and unwittingly prepare the way for an action against him by the builder for damages.

There will be very few situations where attention to most or all of the points noted cannot be given at the expense of a very reasonable degree of attention and time, and there can be no question that time and attention so expended will in the prevention of misunderstanding, legal difficulties, disputes between the parties, and the expense consequent upon all of these, repay the architect, the owner and the builder in ample measure, and assure to them a feeling and a certainty of definiteness and safety in their mutual dealings, which would otherwise be lacking in a marked degree. 

APPENDICES 



\section{APPENDIX A \\ DECISIONS FOR REFERENCE READING}

It is believed that the original text of the decisions in a number of leading cases dealing generally with the duties, rights and liabilities of the architect, owner and contractor, especially the former, will be found of interest.

The cases following are cited in the text, but a reading of the decisions in their original form and substantial entirety will be helpful, as supplementing and emphasizing the points already made and in connection with which they have been cited.

The decisions selected deal with the general duties of and relationship between the architect, owner and builder, the degree of performance and character of work required of the contractor, the extent of the authority of the architect as agent of the owner, the effect of provisions for superintendence and approval by the architect, the liability of the architect for damage resulting from his negligence, the right of the architect to compensation, the measure of his compensation and his rights as a lienor.

\section{COOMBS v. BEEDE,}

(89 Me., 187; 36 Atlantic Reporter, 104.)

Peters, C. J.-It is not questioned that the plaintiff, a professional architect, was employed by the defendant to 
prepare plans and specifications for a house which the defendant intended to have built for himself in the city of Lewiston. On the trial of this action, brought by the plaintiff to recover compensation for services rendered by him in such employment, the defendant sought to establish that, although certain services were rendered by the plaintiff, such services were not beneficial to him, for the reason that they were performed in a manner contrary to his express direction and wishes.

In an examination of the merits of the controversy between these parties, we must bear in mind that the plaintiff was not a contractor who had entered into an agreement to construct a house for the defendant, but was merely an agent of the defendant to assist him in building one. The responsibility resting on an architect is essentially the same as that which rests upon the lawyer to his client, or upon the physician to his patient, or which rests upon any one to another where such person pretends to possess some skill and ability in some special employment, and offers his services to the public on account of his fitness to act in the line of business for which he may be employed. The undertaking of an architect implies that he possesses skill and ability, including taste, sufficient to enable him to perform the required services at least ordinarily and reasonably well; and that he will exercise and apply, in the given case, his skill and ability, his judgment and taste, reasonably and without neglect. But the undertaking does not imply or warrant a satisfactory result. It will be enough that any failure shall not be by the fault of the architect. There is no implied promise that miscalculations may not occur. An error of judgment is not necessarily evidence of a want of skill or care, for mistakes and miscalculations are incident to all the business of life.

In a case at nisi prius in one of our counties, where a controversy arose very similar to the present, the defendant there contending that the plans called for a 
too expensive house, and that there had been a departure from the instructions given by the employer, Haskell, J., gave a ruling, which we adopt as an acceptable statement of the law here, as follows: "The plaintiffs continued in the execution of the plans. They procured the details, and perfected the entire set of plans. For some reason those plans were rejected by the defendants. The plaintiffs say that it was because they did not give the house sufficient size and capacity and arrangement to suit them, and that they preferred an entirely different house, $-a$ house of different dimensions and different architectural proportions. The defendants say it was because they found the plans impracticable, and that the arrangement of the plans called for so great an outlay that it rendered it too expensive for them to be carried out and adopted; and they say that that was on account of the mistake of the plaintiffs in not properly advising them and in deceiving them as to the practicability of the plans.

"Now, gentlemen, in determining the rights of the parties, it is well to consider what the legal duty of the plaintiffs was to the defendants. The architect is skilled in the art of building houses. Those who employ him have a right to his best judgment, to his skill, to his advice, to consultations with him, and to his absolute fidelity and good faith, and, when the archiect has contributed these things to the person who employs him, his duty has been fulfilled."

In the case at bar the defendant, not relying on any charge against the plaintiff of fraud or negligence, set up at the trial that there was a special promise that the plans should not call for a house to cost exceeding $\$ 2,500$, and contended that, inasmuch as the plans called for a more expensive house than that sum would build, nothing was recoverable for plaintiff's services. And in relation to such contention the presiding justice gave the following instruction: "Well, if that is true,-if $\mathrm{Mr}$. 
Coombs was explicitly told, in addition to the other things, that the building he was designing must not cost over $\$ 2,500$; that he was to make plans and specifications for a building to cost not over that,-why, then, Mr. Coombs, the plaintiff, should have either made plans accordingly, or frankly told Mr. Beede that he could not do it, and declined to do it. If he undertook to make plans with that restriction made to him specifically, why, then, he must do it before he can recover any pay."

We think this instruction was misleading, and without evidence upon which it could be reasonably based. It punishes the plaintiff for what might be merely an honest mistake or miscalculation. It leaves wholly out of consideration the elements of care and good faith. It does not even require that the plaintiff bound himself to the agreement set up by the defendant. The ruling implies a guaranty or warranty, when none was testified to or really pretended.

Of course, it would be too much to say that parties could not make such a shadowy contract as the defense contends for, but it would be so strange and unusual a thing to do, that clear and convincing evidence should be required to prove it. And the testimony exhibits none such to our minds.

Skipping the testimony of the defendant as less adroit and less spirited than that of his wife, who was much the more active of the two in the transaction, we incorporate her statement here, as follows:

"Q. Won't you state to the jury the conversation and what took place?

"A. They had some talk about the fifteen hundred dollar cottage that they had been talking about previously, and conversation was general with regard to the fifteen hundred dollar cottage; and something was said-I think I spoke myself first-about putting on the other story; spoke about its being better economy. Mr. Coombs said: 'Yes, if we studied economy, it certainly was economy 
to build a double tenement ;' and Mr. Beede asked him what it would cost extra to put on the other story, and make a double tenement. He said he thought one thousand dollars. Then Mr. Beede said: 'Well, perhaps you can tell Mr. Coombs something about what kind of a house you want.' I said: 'I don't know what we could have for that money as well as he does. He understands that better than I. But one thing, Mr. Coombs, I don't want it to exceed the twenty-five hundred dollars, and I would rather you would cut it down to twentytwo. Don't you think you could?' He figured a moment, and said he hardly thought we could, including the plumbing, but for twenty-five hundred dollars we could build a house complete. Mr. Beede said if he could make plans for a house to be built, not exceeding twentyfive hundred dollars, he might go ahead, and Mr. Coombs said he would do so, and he would send me up a sketch of the ground floor, to show me what I could have for size.

"Q. Did he do so?

"A. He did. He told me I might change over whatever I pleased. Something about the sink, I believe, I wanted differently. I told him that the arrangement of the rooms was all right, I guessed.

"Q. Now to come to the next conversation you had with him.

"A. Then, after I carried that sketch down he sent me up a little sketch of what the elevation would be, and I looked that over, and I thought it was rather more elaborate than what I expected for twenty-five hundred dollars, and talked with some of my friends about it, and they seemed to think the same. The piazza, I spoke of that, and they said they should judge that piazza would cost two hundred and fifty dollars. I went down and talked with Mr. Coombs. Told him that I felt that it was a little extravagant. He said he guessed not; but I thought he felt as though it would perhaps overrun 
twenty-five hundred dollars, and asked him, 'What do you think such a house ought to cost ?' and he said, 'Well, possibly three thousand dollars.' I said, 'We can't do that; we want a twenty-five hundred dollar house and must cut this down,' and he said, 'You don't want to spoil your house for a few hundred dollars.' I said, 'We are willing to have it a little plainer, rather than put in more money.' He said, 'Well, just as you say. I will cut that piazza down, make less posts, take off the fancy work around the rail, and so forth, and cut it down.' And he did so on the final sketches."

By this statement it does not appear that the plaintiff was to prepare plans for any particular kind of house to cost $\$ 2,500$, excepting that it was to be a two-tenement house, with one tenement over the other. Could not the plaintiff have planned a house answering this description which would not have cost that sum, or even half that sum, if allowed to do so? But the difficulty was that the defendant's wife not only wanted the expenditure not to exceed $\$ 2,500$, but she wanted, at the same time, a house worth much more than that sum, and the architect was trying in good faith to accomplish the desired result as best he could. After the plaintiff had engaged to make the plans, and not before, the defendant calls on his wife, according to her testimony, to inform the plaintiff what kind of a house she wanted. Was it expected that he had promised to secure to her a house to her liking for $\$ 2,500$, irrespective of actual cost or worth, and that he was agreeing to expend his services gratuitously if he did not succeed in doing so? We see nothing even in the defendant's side of the case justifying such a position. The plaintiff certainly could have reduced the cost upon the plans, and have earned his compensation, if the wife had permitted him to do so.

The plaintiff gives a different version of the transaction, denying that any particular limit was fixed within which he was required to bring the cost of the house, 
other than that the wife desired to get as much of a house as she could for as small a price as possible, and he did all he could to assist her in her ideas. We have no doubt ourselves that there were talks about $\$ 2,500$, as a proximate, but not conclusive, price, and that there were no rigorous or unalterable instructions or conditions about it. The plaintiff says that, after the plans were first completed, the wife required expensive alterations to be made in them, and, while she does not deny the fact, she is not willing to admit that she remembers it.

The bids which came in after the plans were advertised were disappointing, there being but four in all, and ranging in amount from $\$ 3,300$ to $\$ 4,400$, showing the moral impossibility of an architect being able to fix precisely the cost of any building if the cost is to be measured in any such capricious way as by the bids of contractors. It was at an unfavorable time of the year, when the contractors had on hand all the work they could do, and still the plaintiff, by his perseverance, virtually obtained afterwards a bid for $\$ 3,100$, which the defendant refused to accept, nor would he or his wife consent to cut down the plans so as to obtain a bid within the price desired; and so the plaintiff advised the wife to postpone the matter until spring, when the conditions would be more favorable, and she frankly accepted the advice.

There was, however, no waiting till spring before the defendant had his house built. He says he was informed by several persons that he would not be obliged to pay for the plans unless he used them, and he concluded to buy his materials and hire the labor by the day. His wife had become sufficiently posted, by her experience with the plaintiff and remembrance of his work, to enable her to make sketches of what she wanted, and so she, with the assistance of the carpenter in her service, acted as architect herself; and the defendant, during the same fall and winter, erected a house and stable on their lot at a cost of over $\$ 3,500$. The wife says that the house 
built by her "was brought to the same degree of completion that a house would have been by his (plaintiff's) specifications for little less than $\$ 2,700$." So that plaintiff's calculations, tested by actual cost instead of by contractor's bids, were less than $\$ 200$ of variance from the standard which the defendant and his wife pretend was prescribed for him by them.

We can perceive no ground upon which, as the testimony stands, the verdict could have been rightfully rendered. Even if the defendant's version of the facts be true, then the undertaking of the plaintiff was to make plans for a house to cost $\$ 2,500$, and no more; and if, acting in good faith, he exercised his skill and ability in an endeavor to bring about that result, that is all that could be expected or required of him; and no defense is established against his claim even if he failed in his attempt. But if the house designed by him could be built for less than $\$ 2,700$, it could hardly be called a failure, especially in view of the interferences on the part of the defendant's wife; nor a failure if the plaintiff could have so altered his plans as to reduce the house in price, and it seems to us preposterous to say that he could not; and he was willing to make alterations, and the defendant or his wife would not consent thereto.

Motion sustained.

\section{GLACIUS v. BLACK, (50 N. Y. 145.)}

Church, Ch. J.- I47: This is an action upon a claim filed under the mechanic's lien law. The contractors are builders, and contracted to make certain alterations and repairs upon the defendant's house for $\$ 1,326$; one-half to be paid when the lath were on, and the balance when the work was done completely and accepted. The work consisted principally of taking off an old peak roof and substituting a French or Mansard roof and fin- 
ishing off the upper story, and making other repairs in the interior of the house. The case was tried before a referee, and is very voluminous. . . . The referee found for the plaintiffs the whole amount of the claim, less twenty-five dollars, which he found as damages for defective work and materials.

The findings of fact, if supported by any evidence, are conclusive upon this Court, and we can only deal with the legal questions involved. A reference to some general principles of law will aid in elucidating the controlling points in the case. It is well settled in this State that where a party has entered into a contract to perform work and furnish materials of a specified character, and the other party agrees to pay for the same upon the performance of the contract, although the work may be performed and materials furnished, yet, if not done in the manner stipulated, no action will lie for compensation. When performance is a condition of payment the former must be shown to entitle a party to recover unless it has been waived or released. The case of Smith v. Brady ( I7 N. Y., I73), reviewing the principal authorities on the subject, is full and explicit on this point. This is a general rule, applying to contracts of this character as well as others. As was said in the above case, "There is, in a just view of the question, no hardship in requiring builders to perform their contracts in order to entitle themselves to payment where the employer has agreed to pay only on that condition." As, however, this class of contracts embrace many particulars which it is difficult, if not impracticable, to comply with, with entire exactness, the apparent rigor of the general rule has been so far relaxed as that a substantial compliance will be deemed sufficient. As was properly expressed by Allen, J., in Sinclair $v$. Talmadge (35 Barb., 602), "If there has been no willful departure from the terms of the contract, or omission in essential points, and the laborer has honestly and faithfully performed the contract 
in all its material and substantial particulars, he will not be held to have forfeited his right to remuneration by reason of mere technical, inadvertent or unimportant omissions or defects. The law imposes no such liability, and enforces no such penalty." The question in each case will, of course, be an open one, where defects exist, whether they are substantial or technical and unimportant. This is a question of fact. The referee has found that defects existed, but has not passed upon the question whether they were substantial so as to defeat any right of action, or so trivial and unimportant as to require the application of the modified rule before stated; nor has he furnished any guide by which we can, as a question of law, determine that question, except that he finds that the plaintiffs intended in good faith to perform their contract. The referee finds, in the fiftieth clause of what are called special findings, "That the work was never completed by the claimants according to the plans and specifications in the respects found by me in my report, or specially found by me herein."

The defects thus found are quite numerous, and embrace defects in materials and workmanship, in the plastering, the walls were out of plumb, the windows were too narrow, an omission to put sills under cross partitions; there was some leakage; folding doors were too narrow and too short; an omission to replace lightning-rods, torn down to perform the work; defective materials and workmanship in the mouldings and casings, and some other similar defects. As to some of the defects, the referee found that they had been waived, or should have been objected to while the work was progressing; as to others, that there was no evidence of damages by reason of them; and, as to others, he allowed compensation in damages, but did not find whether they were of such a material character as to preclude a recovery or not; nor, upon the theory upon which he determined the case, 
was it essential that he should do so. That theory was that, by the terms of the contract, the architect had power to bind both parties by his acceptance of the work and materials so far as to enable the plaintiffs to maintain an action, that the architect superintended the work and accepted it after it was completed, and that the defendant was bound thereby to pay for it, less the value of the defects proved.

After ar examination of the case, I do not think this proposition can be sustained. In the first place the contract confers no power upon the architect to change or alter the plans and specifications; nor is there any provision, found in many such contracts, that the decision of the architect shall be final and conclusive upon the defendant. The contract provides "that the materials to be furnished shall be of the best quality, and the workmanship performed in the best manner, subject to the acceptance or rejection of Edward Wall, architect, and all to be in strict accordance with the plans and specifications, which are signed by the parties of the second part, and form part of this contract." The architect also had power to reject any particular work or materials; and in such case the builders were to remedy the defects. This is all the authority which the architect had under this contract, and his authority was equally known to both parties. It is quite clear to my mind that the acceptance of the work by the architect did not relieve the plaintiffs from their agreement to perform this work according to the plans and specifications. The provisions are distinct and independent. The contract was to be performed in a certain manner, particularly specified in writing; and, in addition, it was to be subject to the acceptance or rejection of the architect; but his acceptance of a different class of work or inferior materials from that contracted for would not bind the defendant to pay for them. She was obliged to pay only where "the work was 
done completely and accepted." The provision for acceptance was an additional safeguard against defects not discernible by an unskilled person.

This principle was substantially held in Bird $v$. Smith (64 E. C. L. R., 785), where the contract was for the sale and delivery to the plaintiff of a quantity of iron rails of certain weights, shapes and dimensions, and to be inspected and certified as then agreed upon, and in quality equal to any rails made in Staffordshire. A plea that the rails were inspected, certified and approved by an agent of the plaintiff's, as provided in the contract, was held bad on demurrer on the ground (among others) that "each stipulation is, in its terms, distinct, and, in its nature, as an absolute warranty for quality, may well be required, in addition to a provision for inspection and approval, to guard against defects which inspection cannot discover."

In Wyckoff $v$. Meyers ( 44 N. Y., I43), where it was held that the certificate of the architect was conclusive upon both parties, the contract provided that payment should be made upon the certificate of the architect; and it was also provided that disputes respecting the construction and meaning of the drawings and specifications should be submitted to the architects, whose decision should be conclusive upon the parties. Every contract must be construed by its own terms, and, I think, the true construction of this contract is, that the provision subjecting the work and materials to the acceptance of Mr. Wall was for the benefit of the defendant as an additional protection to the agreement, on the part of the builders, to perform the work according to the plans and specifications, and such seems to have been the understanding of both parties by the course of evidence on the trial. The acceptance by the architect would be important in establishing that the work and materials were in compliance with the contract, but would not be sufficient 
to sustain a recovery if it appeared that the contract had not been substantially performed.

We cannot determine whether this construction of the contract would have changed the result at the trial before the referee or not, because the referee did not consider or pass upon the question of substantial performance, but held that such performance was established by the acceptance of the architect, so far as to enable the plaintiff to maintain the action. In this he erred. But I cannot agree that there was such acceptance of the work by the architect as to bind the defendant, even if he had authority to bind her. The facts, upon which the referee found that the architect accepted the work, are stated in the report, and are embraced in numerous specifications; but so far as material are, substantially, that the architect did not see the work during the taking down of the old roof, erecting the studding and putting up the new roof, nor the partitions of the attic floor, or before the lath and plastering were on, and that he only saw the work, on an average, about once a week; that about the time the work was finished he and one of the claimants went over a portion of the work together in the absence of the owner, but did not thoroughly examine the work; that he pointed out certain things to be done, and on the next day the other claimant went to the house to do the things which his co-claimant stated that the architect pointed out, but did not do all of them; that a day or two afterward, the architect not having seen the work meantime, met one of the claimants in the street and asked him if the things he had specified had been done; that the claimant replied that they had, and asked for a certificate, which the architect promised to give in a few days, after he had been over to see the work; "that afterward the claimants called again upon the architect at his home for the certificate, and that he told them that he had not seen the work yet and promised to leave a cer- 
tificate at the claimants' house in a few days after he had been over to see the work, and at the same time advised the claimants to go and compromise with the owner, and if they could not make it out (the settlement) he would give the certificate anyway;" that the architect did not know of the objections of the owner to the work, and on making a thorough examination he was of opinion that the work was inferior in quality and in workmanship and did not comply with the contract in all respects, and never gave the certificate or otherwise accepted the work.

Conceding the power claimed for the architect, these facts fail to establish such an acceptance as would foreclose the defendant. At most, it was only a promise to accept, and that, too, in substance after a subsequent satisfactory examination of the work. The work was not satisfactory when the examination was subsequently made. But if the acceptance had been unqualified and a certificate given without knowing the facts concerning which a subsequent examination showed he was mistaken, the acceptance and certificate would have had no binding force. Fraud or mistake vitiates the certificate in those cases where a certificate is otherwise conclusive. (44 N. Y., supra.) So that, in any point of view, the referee erred in holding that the defendant was in any degree prejudiced in her defense by what was said or done by the architect upon the subject of the acceptance of the work. There are other conclusions stated in the numerous findings of the referee to which I can not fully assent, but which are comparatively subordinate, and as there must be a new trial I do not deem it material to examine them. It is not intended, in the views above expressed, to decide or intimate an opinion that the claimants are not entitled to maintain this action and recover the contract price, less such reasonable damages as the defendant has sustained by reason of the defects and omissions appearing in the work or materials. If the 
claimants acted in good faith, and honestly performed the contract in all substantial particulars, they should not be compelled to forfeit the whole payment by reason of inadvertent or slight defects. So, too, the plaintiffs may recover if the defendant, by herself or authorized agent, has waived full performance, or consented to accept the work subject to deductions for defects. On the other hand, if these defects and omissions are so numerous and pervading as to show that the whole job was done in a slovenly and improper manner, not conforming substantially with the plans and specifications, and there has been no waiver, there is no rule of law or morality which entitled the claimant to compensation. From the nature of the case it cannot be difficult to reach a just result at another trial, or even by a proper spirit of accommodation on the part of the parties themselves to arrive at such a result, without further litigation or expense.

The point is made by the appellant that the judgment should be reversed without a new trial, claiming that the lien has expired, and no personal judgment can be rendered against the defendant. This position is not tenable. If the lien has expired the action can still be prosecuted as a personal action. The twentieth section, as amended in $187 \mathrm{I}$, is explicit in retaining the lien, but it is unnecessary to determine now whether the lien continues or not.

Judgment reversed and new trial granted, costs to abide the event.

All concur, except Grover, J., not voting. Judgment reversed.

GILMORE v. STEVENS,

(54 How. Pr. (N. Y.), I97.)

Trial Term, March, 1877.

Arthur Gilman, an architect, sues Mrs. Marietta R. Stevens, the defendant, for a balance of $\$ 832$ upon an 
account for professional services in completing and building an addition to the Stevens apartment house, corner of Twenty-seventh Street and Fifth Avenue, New York City, the other portion of said apartment house having been constructed by another architect, Mr. R. M. Hunt. The complaint likewise claimed full compensation as upon an estimated cost of $\$ 425,000$, according to the schedule of the Institute of Architects, for professional services in and about a hotel proposed to be built by the defendant (as alleged) upon land belonging to the late Paran Stevens, the defendant's husband, at the corner of Thirty-seventh Street and Fifth Avenue, New York City, which last hotel was never built. The answer is a general denial, and alleges for a further defense, and as well by way of counter-claim, that the plaintiff in his professional capacity as an architect undertook and agreed to supervise the construction of the Twenty-seventh street house, and to see that the same was built of the best of material, and in a strong and substantial manner, and made suitable for its purpose, while in fact and in consequence of "negligence, and want of skill and attention" on the part of the plaintiff the said building was not constructed in a strong and substantial manner. "Everything necessary to make the same strong and substantial was not done." "The materials used in and about the construction of the same were not of the best character, and the work and labor upon the same were not faithfully performed, and that in consequence thereof the said building is less in value by the sum of $\$ 20,000$ and upwards than it should be if the plaintiff had performed his agreement and discharged his duty in the premises, by reason whereof, as the defendant is advised and believes, the plaintiff is liable to her in the sum of $\$ 20,000$ and upwards, for which, by way of counter-claim, she asks judgment against him in this action, with interest."

The defendant's testimony was to the effect that she 
merely considered a proposal to build a hotel at Thirtyseventh Street and never decided so to do, nor employed plaintiff to design such an hotel, and that the plaintiff's plans, if he made any such, were an adaptation of plans already made by plaintiff for another person, and that she estimated her damage from the ill construction of the Twenty-seventh Street house at $\$ 20,000$. With reference to the Twenty-seventh Street house the defendant's son-in-law testified that certain arches over the store windows in the first floor were weak so that he saw the bricks bulging out above them.

No architect was called by the defendant, but two builders testified in her behalf that, in their opinion, the material used was not of the best quality and the work was inferior, and that the value of the building was very much less on account of those facts. On the part of the plaintiff five builders testified to their having made offers to put the building in good condition for comparatively small sums ranging from $\$ 1,000$ to $\$ 2,000$, and that the need of repairs was largely due to the fact that the building was erected in winter and without the heat which defendant had agreed to furnish, and that such repairs were usually required, and various architects were called to prove the plaintiff's experience and professional standing. The specifications were put in as tending to show that first-class work and material were not contracted for on the Twenty-seventh Street house, as the specifications called in some places for "2d quality pine" and for "two coat work in plastering." The plaintiff testified that the defendant ordered and insisted upon repeated changes from his plans and directions, and failed to make the payments agreed on and needed to carry on the work. As to the denial of employment upon the Thirty-seventh Street hotel letters of the defendant were put in evidence in one of which she urged the plaintiff to hasten those plans, and in another of which suggested to the proposed builder of the last hotel to "excavate under" a 
florist who was occupying the Thirty-seventh Street land and "tumble him in" if he did not get out of his (the builder's) way. The court allowed evidence as under the before-mentioned allegations of the answer as to certain payments (referred to in the charge) which plaintiff received from the builder. The plaintiff admitted receiving certain sums of money from the builder at the time of the alleged proposition to build at Thirty-seventh Street, the same builder having then not altogether completed the Twenty-seventh Street house, and the plaintiff alleged that such moneys were advances and loans to enable him to employ a staff of draughtsmen upon the Thirty-seventh Street plans at the defendant's behest. The drawings and plans offered in evidence as for the contemplated hotel at Thirty-seventh Street, contained no "working plans" nor "detail drawings," as to which fact there was at first a misunderstanding. The schedule above referred to is admitted in evidence and reads: "Schedule of charges adopted by the American Institute of Architects. For full professional services (including superintendence), five per cent upon the cost of the work. Partial service as follows: For preliminary studies, one per cent; for preliminary studies, general drawings and specifications, two and a-half per cent; for preliminary studies, general drawings, details and specifications, three and a-half per cent. For stores, three per cent upon the cost, divided in the above ratio. For works that cost less than $\$ 5,000$, or for monumental and decorative work, and designs for furniture, a special rate in excess of the above. For alterations and additions, an additional charge to be made for surveys and measurements. Necessary traveling expenses to be paid by the client. The architect's payments are successively due as his work is completed, in the order of the above classifications. Until an actual estimate is received, the charges are based upon the proposed cost of the works, and the payments are received as installments of the fee, which is 
based upon the actual cost. Drawings, as instruments of service, are the property of the architect. By order Richard Upjohn, President, Carl Pfeifer, Secretary."

John Tozenshend and W. G. Peckham, Jr., for plaintiff.

John E. Parsons, for defendant.

The cause was tried before Hon. H. C. VAN Vorst and a jury. The judge charged the jury as follows:

VAN VoRsT, J.-The plaintiff, gentlemen, an architect, interposes in this action two distinct claims for services, alleged to have been performed by him in his profession, for the defendant. The first is for drawing plans and specifications, making estimates and calculating quantities, in respect to building on an addition to a building on the south side of Twenty-seventh Street, and the west side of Fifth Avenue, and also for superintending that work.

There is no dispute but that the plaintiff rendered this specific service. In fact, it is conceded that he drew the plans and specifications, and that he supervised the work upon the addition to the apartment-house. The evidence is that for such services the customary charge is five per cent, computed upon the cost of the building. It is established that the claim for those services has all been adjusted and paid by the defendant, with the exception of a balance of about $\$ 832$, which amount the plaintiff still claims to be due and owing to him for his services in respect to the addition to the apartment-house.

Now, gentlemen, by the contract under which this building was erected, the contractor, Mrs. Jones, undertook to complete the work on or before the Ist of February, 1874 , and the contract, which is in writing, states that the work was to be done in a good, workmanlike and substantial manner, to the satisfaction, and under 
the direction, of the plaintiff, the architect, to be testified by a writing or certificate under his seal. These are significant words, gentlemen, and, doubtless, you will not lose sight of them. The duty of the plaintiff, therefore, it is quite clear, was to see to it that the building was erected, having reference now, gentlemen, to those terms that I have suggested to you as being significant. The work had to be done in accordance with the plans, elevations, sections and specifications furnished by the plaintiff, and to his satisfaction; and the payment to the contractor for the work as it progressed, which was to be paid in fifteen installments, was dependent, in each instance, upon a certificate in writing, to be obtained from the plaintiff, that the contractor was entitled to the specific payments. Of course, the giving of those certificates contemplated that the contractor had done the work in conformity with the plans and specifications, and to the satisfaction of the plaintiff. The plaintiff then occupied an important and highly responsible position in relation to this work, both to the contractor and to the defendant. It was clearly his duty to exercise proper vigilance and skill in the supervision of this work; to see that it was done in the manner contemplated by the specifications, and in a good, workmanlike and substantial manner.

The defendant claims that the plaintiff has neglected his duty in his employment, and that through such neglect she has sustained damage; and, gentlemen, this is the subject that chiefly, I may say almost exclusively, demands your attention upon this branch of the case. Was the material used of the quality required? Was the work done in the manner contemplated by the contractthe plans and specifications? The plaintiff gave the certificates called for, and upon their faith the defendant has paid out, as is claimed by her, the cost of the structure. Fourteen of these certificates, signed by the plaintiff, have been produced in evidence; the last, the fifteenth certificate, is not produced according to my rec- 
ollection of the case, although there has been, I believe, some evidence given with regard to the substance of its contents, from a memorandum that Mr. Gilman had.

Gentlemen, it was the duty of the plaintiff to exercise the skill and attention required of a person standing in the relation he did with respect to the materials to be used and the work to be done. Does the evidence show that he has been at fault in these respects? Now, that is for you to determine. Evidence has been adduced in regard to the material used and its character, and as to the manner in which the work has been done. The painting and plastering, it is claimed, are not such as is called for; that they are defective in character and execution. Gentlemen, you and I are greatly indebted to the learned gentlemen who have tried this case with signal ability on each side; and they have called your attention to the evidence, Mr. Parsons giving you his views, going into details with regard to the points in which he says this work has not been done according to the plans and specifications, and the learned gentlemen on the other side have given you their views of the same branch of the case. Therefore, I say, I am relieved from going into detail with regard to these specific points in which it is claimed that the work has not been done according to the plans and specifications, and I am the more reluctant, gentlemen, to enter into any statement upon that point, because $I$ am aware that it is a part of the case, entirely and exclusively within your province, and because by mentioning one subject or omitting to mention another it might be considered that I attached an undue importance to one and did not properly appreciate the importance of another. Therefore I am disposed to leave this entire matter where it properly belongs, with you, and upon you the responsibility must rest to determine it properly and correctly.

But, gentlemen, you will determine, under the evidence, how the facts are in these regards, and if the work 
and material were defective, then whether such defects are in consequence of, or owing to, the negligence of the plaintiff in any regard. In determining this you will doubtless consider, and it would be your duty to consider, the obligation and the duty the plaintiff assumed and the manner in which he has met those obligations and discharged the duty, and whether the defects are of such a character as by the exercise of the ordinary skill and attention of a person of his profession and in his relation they could have been guarded against and prevented.

Now, gentlemen, for any deficiency, for any damage the defendant has sustained through the neglect of the plaintiff, if there be any neglect, in the superintending of this work and in giving the certificates upon which she has made payments, the plaintiff is liable and the amount of such damage should be allowed in this action to her.

The next claim of the plaintiff is for drawing plans and specifications and for other services as an architect in regard to a building proposed to be erected on the corner of Thirty-seventh Street and Fifth Avenue. The building was not erected and the plaintiff's claim therefor, is, by himself, limited to two and a half per cent instead of the full charge of five per cent for drawing the plans, \&c., and three quarters of one per cent for taking the quantities, in all amounting to the sum of $\$ 10,562$. The plaintiff claimed that he performed these services, and that he did so upon the defendant's retainer. He has been examined himself as a witness on this subject, as has also Mr. Crooks, and it is claimed by the plaintiff's counsel that there is found in the testimony of other witnesses corroboration of the principal fact, as he claims, that plaintiff was employed by the defendant to render these specific services for which he seeks a recovery in this action growing out of the Thirty-seventh property, which was contemplated to be improved. Now, in order to sustain the plaintiff's claim for these services 
in respect to this Thirty-seventh Street property, you are to be satisfied that he performed the work and services necessary to entitle him to the commission charged; that he performed that service which would entitle him to a commission of two and one-half per cent for drawing the plans and specifications, and three quarters of one per cent for taking out the quantities: that he actually performed this service; that is to say, that he drew and completed the plans and estimates, and computed the quantities for a building proposed to be erected by the defendant upon the property in question. I don't suppose that the plaintiff himself would insist that for an immature plan, for an entrance upon a service of this character; that is, the drawing of plans and specifications, and the taking out of quantities, and the like of that, for an incomplete service in that regard he would be entitled to his full commission, and therefore his claim is that he has rendered all the services necessary to entitle him to the full commission. Of course, the drawing of plans for a building would seem in reason to be a sort of unit, a complete thing; that there is everything here from which the building might be erected from its foundation to the roof or the chimneys on the roof, everything. I suppose that these papers, which are designated by the general term, plans and specifications, and drawings, and estimates, and all that, represent the complete building as far as it can be represented on paper. I think that would in reason be the construction to be put upon such an effort as is contemplated by the case. Now, gentlemen, I say that you are to be satisfied that the work was done in that way substantially and completely; in other words, that he has rendered all the service to entitle him to such a commission as that.

Now, as the charge made by the plaintiff is upon the basis of the contemplated cost of the building, it would seem that you should be satisfied that the arrangements between the plaintiff and defendant had progressed, ad- 
vanced, to the position that the expense of the contemplated building had been substantially assumed or in judgment reached, and with respect to which the plans and estimates were made or accommodated. It would seem that the cost of the improvement is an element in arriving at the amount of compensation that the plaintiff would be entitled to, or that an architect would be entitled to, for performing these services. It must be upon the basis of the cost of the building and the completion of all the plans and specifications with regard to it. Now, if that were all that belongs to this branch of the case probably you could not have a great deal of difficulty, and at any rate that your determination could be more rapidly reached were it not for some other considerations which are to be noticed. But before stating that I presume, gentlemen, that I may make a general statement to you, which will doubtless be satisfactory to your reason: That parties are entitled to be paid for such work, labor and services as they have rendered to others at their request and for their advantage. That is an ordinary rule, good in morals as in law. Now, if this work has been performed in the manner that I have described, is there anything in this case which relieves the defendant from paying the plaintiff's claim?

The defendant herself has been examined as a witness, and she says, among other things, that she did not own the property. But, gentlemen, the mere fact that Mrs. Stevens did not own the property is not enough to excuse her, and I do not understand her learned counsel to advance that proposition either because she might have contemplated acquiring it for the purpose of improving it, and in that way employed the plaintiff to perform the services which he claims to have rendered; and whether she ever acquired the property or not, it would be immaterial if she did employ him to render the service, and he rendered it at her request without any other condition as to payment. I say that the mere fact that she did 
not own the property herself, separated from every other consideration, would be no reason to relieve her from her obligation to pay for the work which had been performed, if it was performed at her request.

But the defendant claims, among other things, that she did contemplate acquiring the property and improving it, and it is within her evidence, it is within her claim at any rate, or that of her counsel, that this was substantially a conditional affair-it is her theory of the case, that it was the understanding that, for whatever services plaintiff performed in the immature condition in which the whole arrangement was, he was not to be paid; in other words, that he said it should cost her nothing. There seems to be no controversy, as I have already stated, about there being a balance due to Mr. Gilman for services upon the apartment-house. His claim, with regard to services upon the Thirty-seventh Street house, is disputed entirely, and the defendant sets up a claim for damages. As I have stated before, if the defendant has sustained any damage through the plaintiff's negligence, it is proper for you, and you should set off the damage she has so sustained against the claim on the Twenty-seventh Street house; and if that is all there is of the case under the pleadings, she would be entitled to a judgment for any overplus of damages, if there is any in her favor. But if you come to the conclusion that the plaintiff is entitled to pay for his services, for the completion of the drawings, plans and specifications for the Thirty-seventh Street house, then you may set off against both claims whatever damages, if any, you find she has sustained through the negligence of the plaintiff, if he has been guilty of any negligence (which I have already described to you in the other part of the case) you may set it off against that, and for any residue in his favor, if there is any, you should render him a judgment for such residue. I think, gentlemen, that is all that is necessary for me to say about that. This is a case of importance to the par- 
ties; it is important to the plaintiff; it is important to the defendant; and I cannot think that your labors will be protracted under the examination which the case has received at the hands of the intelligent counsel, to whom its care has been intrusted.

The plaintiff asks me to charge you, and I do charge you, "That an architect is only required to perform his work with ordinary care, diligence and skill. Ordinary or due skill means that degree of skill which men engaged in that peculiar art usually employ. It does not mean that high degree of skill which belongs only to a few men of extraordinary endowments and capacity.

"That the burden is upon the defendant to establish that the plaintiff did not exercise ordinary care, diligence and skill in his superintendence of the building, and that unless the jury are satisfied that the plaintiff did not exercise ordinary care, diligence and skill in such superintendence, the plaintiff is entitled to recover for his services as architect for the addition to the Stevens house, so called.

"That the mere fact that the plaintiff introduced or recommended Jones to defendant, or recommended defendant to employ Jones, does not make the plaintiff responsible in this action for the intemperance or other misconduct of Jones.

"That for any misfeasance of Jones in the matter of the contract, Jones himself, or Mrs. Jones, or her surety alone, is responsible.

"That the defendant, not having set up any defense of fraud or collusion between plaintiff and Jones in her answer, the jury are not to consider that as a question in the case."

With respect to that, I say that that question of absolute fraud is not involved in this action. The question is whether plaintiff has neglected his duty as superintending architect to the defendant's injury. If there was any collusion between Jones and the plaintiff, it has 
no bearing otherwise than as it affects the manner in which the plaintiff discharged his duty to the defendant, and whether any negligence grew out of it to her injury.

"That for any delay in the completion of the contract, and for any damages arising therefrom, the plaintiff is in no case responsible. For any damage in this regard the defendant has her remedy on the contract." With respect to that, I say that is so, unless the delay was in some way the result of the plaintiff's negligence in superintending, and could have been avoided by the exercise of ordinary care on his part; and that if there is any liability for damages flowing from it, it would be the approximate damage flowing from such a neglect of duty.

"That if the jury are satisfied the plaintiff did not exercise ordinary care, diligence and skill in the superintendence of the addition to the Stevens house, then the defendant is entitled to such damages as were occasioned thereby, and such damages are the costs of making the work a good job according to the requirements of the contract." That is so in regard to those particular matters. If it be in that condition that this request contemplates, or assumes that the cost of making the work a good job according to the contract would be the measure of damages, and I do not understand the learned counsel for the defendant even to dissent from that, judging from the manner in which he has conducted that branch of the case, because the defendant's counsel has introduced evidence with regard to these particular points, to show what it would cost to make the premises according to the plans and specifications, or to render them in a good and workmanlike condition in the particulars referred to there.

"That there is no evidence of any loss of tenants or any loss of rent, or that the house, for all purposes for which it was intended, did not fully answer the object intended." Now, gentlemen, I do not myself remember 
that there is any evidence of any loss of rents. My impression is the other way, that there is no such evidence; but it is for you, entirely, to pass upon the other question embraced in this; whether the buildings did not fully answer the object intended, that is for you to determine under the evidence.

"That as to the charge for preparing the plans respecting the Thirty-seventh Street lots, if the jury believe that the defendant did authorize the preparation of said plans, the plaintiff is entitled to recover his fees for such services." This assumes that he rendered the services at her request, or for her advantage.

"That the fees for preparing such plans, if payable at all, are two and a-half per cent on the value of the contemplated building." That is correct. I suppose you desire to add the three-fourths of one per cent; you do not say anything about that.

Mr. Peckham: We do not desire to.

The Court: I charge you that the fees, if payable at all, are two and a half per cent upon the contemplated cost of the building. There seems to be no controversy that those are the rates that architects are entitled to recover in cases of this character.

$A$ Juror: I would ask if that does not cover working plans?

The Court: Yes. The next one is:

"That whether the defendant did or did not own, or had or had not elected to take the Thirty-seventh Street lots is not decisive of plaintiff's right to recover or of the defendant's liability to pay. If the defendant ordered the plans to be drawn it was not for the plaintiff to inquire whether or not the defendant had any interest in the ground.

"That the defendant not having paid any of the bills for extras, cannot claim any damages in respect of such extras." Whether she has paid or not for extras is not the question. If she is liable to pay that is enough. 
"That from any damages to which the defendant may have shown herself to be entitled, is to be deducted the value of the extra work for which she has not paid." That I decline to charge in that form. I charge this:

"That Mrs. Stevens is chargeable with the knowledge of the standard and regular rates of architects' fees as asked for by Mr. Gilman on the Thirty-seventh Street hotel, because it appears that she had been charged the same rates by Mr. Gilman in several previous jobs." So much, gentlemen, for the request of the plaintiff.

Mr. Peckham: I ask your honor to charge, that the details technically so called, are not claimed or called for in the charge of two and a-half per cent. One per cent additional is allowed on the schedule for the technical details, which the juror calls the working drawings.

The Court: I charge that.

Mr. Townshend excepts to those parts of the charge plaintiff's requests are not charged.

Defendant's counsel accepts the charge itself but excepts separately to the charge, so far as it concerns the request of the plaintiff on various subjects.

Verdict for the plaintiff $\$ 3,000$.

OTTO L. SPANNHAKE, INC., v. MOUNTAIN CONSTRUCTION COMPANY AND NATIONAL SURETY COMPANY,

\section{( 59 App. Div. (N. Y.) 727.)}

ScotT, J. 728: The defendant Mountain Construction Company made a contract with plaintiff, an architect, to draw plans for and superintend the construction of certain houses in the City of New York. The plaintiff filed a lien for the value of his services both for drawing plans and for superintendence. This action is to foreclose that lien. The City Court awarded judgment to plaintiff for both classes of service. This judgment was modified by the Appellate Term by striking out so much 
of the recovery as represented the value of the plans, allowing plaintiff to recover only for superintendence. In this, as we think, the Appellate Term erred. The general rule to be deduced from the adjudicated cases is that while an architect is not entitled to a mechanic's lien for drawing plans alone, yet when he both draws plans and superintends construction he is entitled to a lien for the value of both plans and superintendence. In Stryker $v$. Cassidy ( 76 N. Y. 50, 53) the Court of Appeals said: "An architect who makes the plans and supervises the erection of a building is within the words and reason of the law." The rule above stated is well illustrated by Rinn v. Electric Power Company (3 App. Div. 305). In that case the architect had drawn plans for a large building, of which, however, only one-half had been erected under his superintendence. He was allowed a lien, in addition to his fees for superintendence, for one-half of the value of the plans which he had prepared for the whole building, the Court remarking that an architect cannot have a lien for making plans alone, but when he makes the plans and supervises the construction "it is the part the architect takes during the construction that draws his services within the lien law." In Thompson-Starrett Co. v. Brooklyn Heights Realty Co. ( I I App. Div. 358) the plaintiff was denied a lien for preparing plans because no building was erected. In the present case the plaintiff not only drew plans but superintended the construction, as was found by the City Court, and virtually affirmed by the Appellate Term, which allowed a recovery for the value of his services for supervision. There is no force in the suggestion that plaintiff should have filed a separate lien on each building. (Woolf v. Schaefer, I03 App. Div. 567.).

The determination of the Appellate Term must be reversed and the judgment of the City Court affirmed, with costs to appellant in this court and at the Appellate Term. 
Ingraham, P. J., Clarke, Dowling and Hotchisiss, J. J., concurred.

Determination reversed and judgment of City Court affirmed, with costs to appellant in this court and at the Appellate Term. Order to be settled on notice. 


\section{APPENDIX B \\ THE STANDARD DOCUMENTS OF THE AMERICAN \\ INSTITUTE OF ARCHITECTS}

(INCLUDING VARIOUS SUPPLEMENTAL FORMS AND SUGGESTIONS ISSUED BY THE INSTITUTE)

(Published by special permission and courtesy of the American Institute of Architects.)

NoTE.-This Form of Agreement is approved by the American Institute of Architects when used with the General Conditions of the Contract issued by the Institute.

\section{THE STANDARD FORM OF AGREEMENT BETWEEN CONTRACTOR AND OWNER}

ISSUED BY THE AMERICAN INSTITUTE OF ARCHITECTS

This form has been approved by the National Association of Builders' Exchanges, The National Association of Master Plumbers, and the National Association of Master Steam and Hot Water Fitters.

Second Edition, Copyright 1915 by the American Institute of Architects, The Octagon, Washington, D. C.

This Form is to be used only with the Standard General Conditions of the Contract.

This Agreement made the.

day of...... in the year Nineteen Hundred and......

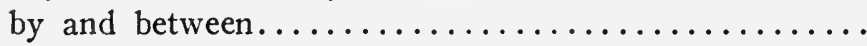

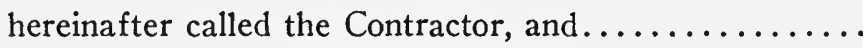

...................... Witnesseth, that the Contractor and the Owner for the considerations hereinafter named agree as follows:

Article I. The Contractor agrees to provide all the materials and to perform all the work shone on the Draw- 
ings and described in the Specifications entitled........

(Here insert the caption descriptive of the work as used in the Proposal, General Conditions, Specifications, and upon the Drawings.)

prepared by

acting as, and in these Contract Documents entitled the Architect, and to do everything required by the General Conditions of the Contract, the Specifications and the Drawings.

Article 2. The Contractor agrees that the work under this Contract shall be substantially completed..........

(Here insert the date or dates of completion, and stipulations as to liquidated damages, if any.)

Article 3. The Owner agrees to pay the Contractor in current funds for the performance of the Contract

$(\$ \ldots \ldots \ldots \ldots \ldots)$ subject

to additions and deductions as provided in the General Conditions of the Contract and to make payments on account thereof as provided therein, as follows:

(Here insert provisions as to the method and times of payments.)

Article 4. The Contractor and the Owner agree that the General Conditions of the Contract, the Specifications and the Drawings, together with this Agreement, form the Contract, and that they are as fully a part of the Contract as if hereto attached or herein repeated; and that the following is an exact enumeration of the Specifications and Drawings:

The Contractor and the Owner for themselves, their suc- 
cessors, executors, administrators and assigns, hereby agree to the full performance of the covenants herein contained.

In Witness Whereof they have hereunto set their hands and seals, the day and year first above written. In Presence of

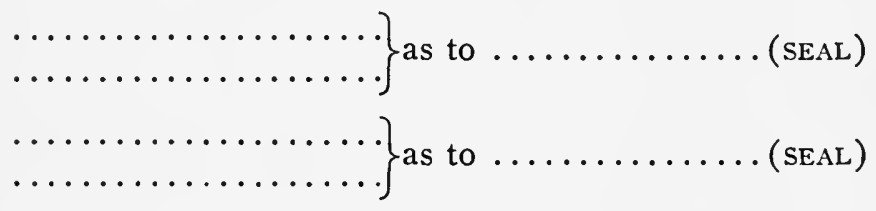

\section{THE GENERAL CONDITIONS OF THE CONTRACT}

\section{Standard Form of the American Institute of Architects}

This form has been approved by the National Association of Builders' Exchanges, The National Association of Master Plumbers, and the National Association of Master Steam and Hot Water Fitters.

Second Edition, Copyright 1915, by the American Institute of Architects, The Octagon, Washington, D. C.

\section{INDEX TO THE ARTICLES OF THE GENERAL CONDITIONS}

1. Definitions.

2. Documents.

3. Details and Instructions.

4. Copies Furnished.

5. Shop Drawings.

6. Drawings on the Work.

7. Ownership of Drawings.

8. Samples.

9. The Architect's Status.

10. The Architect's Decisions.

II. Foreman, Supervision.

12. Materials, Labor, Appliances.

13. Inspection of Work.

14. Correction Before Final Payment.

15. Deductions for Uncorrected Work.

16. Correction After Final Payment.

17. Protection of Work and Property.

18. Emergencies.

19. Damage to Persons.

20. Liability Insurance.

21. Fire Insurance.

22. Guaranty Bonds.

23. Cash Allowances.
24. Changes in the Work.

25. Claims for Extras.

26. Applications for Payments.

27. Certificates and Payments.

28. Payments Withheld.

29. Liens.

30. Permits and Regulations.

31. Royalties and Patents.

32. Use of Premises.

33. Cleaning Up.

34. Cutting, Patching and Digging.

35. Delays.

36. Owner's Right to Do Work.

37. Owner's Right to Terminate Contract.

38. Contractor's Right to Stop Work or Terminate Contract.

39. Damages.

40. Mutual Responsibility of Con. tractors.

4I. Separate Contracts.

42. Assignment.

43. Subcontracts.

44. Relations of Contractor and Subcontractor.

45. Arbitration. 
Article I. Principles and Definitions.-

(a) The Contract Documents consist of the Agreement, the General Conditions of the Contract, the Drawings and Specifications. These form the Contract.

(b) The Owner, the Contractor and the Architect are those named as such in the Agreement. They are treated throughout the Contract Documents as if each were of the singular number and masculine gender.

(c) The Contractor shall, as in Article 43, be responsible to the Owner for the acts and omissions of his subcontractors and of all persons directly or indirectly employed by him or them in connection with the work.

(d) The term Subcontractor includes only those having a direct contract with the Contractor and it includes one who furnishes material even though he does no work.

(e) The term "person" or "anyone" as employed herein shall be taken to include a firm or corporation.

(f) Written notice shall be deemed to have been duly served if delivered in person to the individual or to a member of the firm or to an officer of the corporation for whom it is intended, or if delivered at or mailed to the last business address known to him who gives the notice.

(g) The term "work" of the Contractor or Subcontractor includes labor or materials or both.

(h) When the words "approved," "satisfactory," "equal to," "proper," "as directed," etc., are used, approval, etc., by the Architect is understood.

(j) All time limits stated in the Contract Documents are of the essence of the contract.

(k) The law of the place of building shall govern the construction of this contract.

Art. 2. Execution, Correlation and Intent of Documents.-The Contract Documents shall be signed in 
duplicate by the Owner and Contractor. In case of failure to sign the General Conditions, Drawings or Specifications the Architect shall identify them. Even though the signatures of the Owner and the Contractor may have been attested by witnesses they may be proved by any competent evidence.

The Contract Documents are complementary, and what is called for by any one shall be as binding as if called for by all. The intention of the documents is to include all labor and materials reasonably necessary for the proper execution of the work. It is not intended, however, that materials or work not covered by or properly inferable from any heading, branch, class or trade of the specifications shall be supplied unless distinctly so noted on the drawings. Materials or work described in words which so applied have a well known technical or trade meaning shall be held to refer to such recognized standards.

Art. 3. Detail Drawings and Instructions.-The Architect shall furnish, with reasonable promptness, additional instructions, by means of drawings or otherwise, necessary for the proper execution of the work. All such drawings and instructions shall be consistent with the Contract Documents, true developments thereof, and reasonably inferable therefrom. The work shall be executed in conformity therewith and the Contractor shall do no work without proper drawings and instructions.

The Contractor and the Architect, if either so requests, shall jointly prepare a schedule, subject to change from time to time in accordance with the progress of the work, fixing the latest dates at which the various detail drawings will be required, and the Architect shall furnish them in accordance with that schedule. Under like conditions, a schedule shall be prepared, fixing dates for the submission of shop drawings, for the beginning of manufacture and installation of materials and for the completion of the various parts of the work. 
Art. 4. Copies Furnished.-Unless otherwise provided in the Contract Documents the Architect will furnish to the Contractor, free of charge, all copies of drawings and specifications reasonably necessary for the execution of the work.

Art. 5. Shop Drawings.-The Contractor shall submit two copies of all shop or setting drawings and schedules required for the work of the various trades and the Architect shall pass upon them with reasonable promptness. The Contractor shall make any corrections required by the Architect, file with him two corrected copies and furnish such copies as may be needed. The Architect's approval of such drawings or schedules shall not relieve the Contractor from responsibility for deviations from drawings or specifications, unless he has in writing called the Architect's attention to such deviations at the time of submission, nor shall it relieve him from responsibility for errors of any sort in shop drawings or schedules.

Art. 6. Drawings and Specifications on the Work.The Contractor shall keep one copy of all drawings and specifications on the work, in good order, available to the Architect and to his representatives.

Art. 7. Ownership of Drawings and Models.-All drawings, specifications and copies thereof furnished by the Architect are his property. They are not to be used on other work and, with the exception of the signed contract set, are to be returned to him on request, at the completion of the work. All models are the property of the Owner.

Art. 8. Samples.-The Contractor shall furnish for approval all samples as directed. The work shall be in strict accordance with approved samples.

Art. 9. The Architect's Status.-The Architect shall have general supervision and direction of the work. He is not the agent of the Owner, except as provided in the Contract Documents and when in special instances he is 
authorized by the Owner so to act, and in such instances he shall, upon request, show the Contractor written authority. He has authority to stop the work whenever such stoppage may be necessary to insure the proper execution of the Contract.

In case of the termination of the employment of the Architect, the Owner shall appoint a capable and reputable Architect, whose status under the contract shall be that of the former Architect.

Art. Io. The Architect's Decisions.-The Architect shall, within a reasonable time, make decisions on all claims of the Owner or Contractor and on all other matters relating to the execution and progress of the work or the interpretation of the Contract Documents.

Except as may be otherwise expressly provided in or appended to these General Conditions or as particularly set forth in the specifications, all the Architect's decisions are subject to arbitration.

Art. II. Foreman, Supervision.-The Contractor shall keep on the work a competent general foreman and any necessary assistants, all satisfactory to the Architect. The general foreman shall not be changed except with the consent of the Architect. The foreman shall represent the Contractor in his absence and all directions given to him shall be as binding as if given to the Contractor. On written request such directions shall be confirmed in writing to the Contractor.

The Contractor shall give efficient supervision to the work, using his best skill and attention. He shall carefully study and compare all drawings, specifications and other instructions and shall at once report to the Architect any error, inconsistency or omission which he may discover.

Art. I2. Materials, Labor, Appliances.-Unless otherwise stipulated, the Contractor shall provide and pay for all materials, labor, water, tools, equipment, light and power necessary for the execution of the work. 
Unless otherwise specified, all materials shall be new and both workmanship and materials shall be of good quality. The Contractor shall, if required, furnish satisfactory evidence as to the kind and quality of materials.

The Contractor shall not employ on the work any unfit person or anyone not skilled in the work assigned to him.

Art. I3. Inspection of Work.-The Owner, the Architect and their representatives shall at all times have access to the work wherever it is in preparation or progress and the Contractor shall provide proper facilities for such access and for inspection.

If the specifications, the Architect's instructions, laws, ordinances or any public authority require any work to be specially tested or approved, the Contractor shall give the Architect timely notice of its readiness for inspection and the Architect shall promptly inspect it. If any such work should be covered up without approval or consent, it must, if required by the Architect, be uncovered for examination at the Contractor's expense.

Re-examination of questioned work may be ordered by the Architect and, if found not in accordance with the Contract, all expense of re-examination and replacement shall be borne by the Contractor, otherwise it shall be allowed as extra work.

Art. I4. Correction of Work Before Final Payment. - The Contractor shall promptly remove from the premises all materials, whether worked or unworked, and take down and remove all portions of the work condemned by the Architect as failing to conform to the Contract ; and the Contractor shall promptly replace and re-execute his own work in accordance with the Contract and without expense to the Owner and shall bear the expense of making good all work of other contractors destroyed or damaged by such removal or replacement.

If the Contractor does not remove such condemned 
work and materials within a reasonable time, fixed by written notice, the Owner may remove them and may store the material at the expense of the Contractor. If the Contractor does not pay the expense of such removal within five days thereafter, the Owner may, upon ten days' written notice, sell such materials at auction or at private sale and shall account for the net proceeds thereof, after deducting all the costs and expenses that should have been borne by the Contractor.

Art. 15. Deductions for Uncorrected Work.-If the Architect deems it inexpedient to correct work injured or not done in accordance with the Contract, the difference in value together with a fair allowance for damage shall be deducted, if acceptable to the Owner.

Art. 16. Correction of Work After Final Payment. -Neither the final certificate nor payment nor any provision in the Contract Documents shall relieve the Contractor of responsibility for negligence or faulty materials or workmanship within the extent and period provided by law and upon written notice he shall remedy any defects due thereto and pay for any damage to other work resulting therefrom. All questions arising under this Article shall be decided under Articles Io and 45 .

Art. 17. Protection of Work and Property.-The Contractor shall continuously maintain adequate protection of all his work from damage and shall protect the Owner's and adjacent property from injury arising in connection with this Contract. He shall make good any such damage or injury, except such as may be directly due to errors in the contract documents.

Art. I8. Emergencies.-In an emergency affecting the safety of life or of the structure or of adjoining property, not considered by the Contractor as within the provisions of Article I7, then the Contractor, without special instruction or authorization from the Architect or Owner, is hereby permitted to act, at his discretion, to prevent such threatened loss or injury and he shall so 
act, without appeal, if so instructed or authorized. Any compensation claimed to be due to him therefor shall be determined under Articles Io and 45 regardless of the limitations in Article 25 and in the second paragraph of Article 24 .

Art. I9. Damage to Persons.-In addition to the liability imposed by law upon the Contractor on account of bodily injury or death suffered through the Contractor's negligence, which liability is not impaired or otherwise affected hereby, the Contractor hereby assumes, in cases not embraced within such legal liability, the obligation to save the owner harmless and indemnify him from every expense, liability or payment (voluntary payments excepted), by reason of any injury to any person or persons, including death, suffered through any act or omission of the Contractor or any Subcontractor, or anyone directly or indirectly employed by either of them, in the prosecution of any work included in this contract.

Art. 20. Liability Insurance.-The Contractor shall maintain such insurance as will protect him from claims under workmen's compensation acts and from any other claims for damages for personal injury, including death, which may arise from operations under this contract. Certificates of such insurance shall be filed with the Owner, if he so require, and shall be subject to his approval for adequacy of protection. The Owner shall be responsible for his own contingent liability.

Art. 21. Fire Insurance.-The Owner shall effect and maintain fire insurance upon the entire structure on which the work of this contract is to be done and upon all materials, tools and appliances in or adjacent thereto and intended for use thereon, to at least eighty per cent of the insurable value thereof. The loss, if any, is to be made adjustable with and payable to the Owner as Trustee for whom it may concern.

All policies shall be open to inspection by the Contractor. If the Owner fails to show them on request or 
if he fails to effect or maintain insurance as above, the Contractor may insure his own interest and charge the cost thereof to the Owner. If the Contractor is damaged by failure of the Owner to maintain such insurance, he may recover under Art. 39.

If required in writing by any party in interest, the Owner as Trustee shall, upon the occurrence of loss, give bond for the proper performance of his duties. $\mathrm{He}$ shall deposit any money received from insurance in an account separate from all his other funds and he shall distribute it in accordance with such agreement as the parties in interest may reach, or under an award of arbitrators appointed, one by the Owner, another by joint action of the other parties in interest, all other procedure being in accordance with Art. 45. If after loss no special agreement is made, replacement of injured work shall be ordered under Art. 24.

The Trustee shall have power to adjust and settle any loss with the insurers unless one of the contractors interested shall object in writing within three working days of the occurrence of loss and thereupon arbitrators shall be chosen as above. The Trustee shall in that case make settlement with the insurers in accordance with the directions of such arbitrators, who shall also, if distribution by arbitration is required, direct such distribution.

Art. 22. Guaranty Bonds.-The Owner shall have the right to require the Contractor to give bond covering the faithful performance of the contract and the payment of all obligations arising thereunder, in such form as the Owner may prescribe and with such sureties as he may approve. If such bond is required by instructions given previous to the receipt of bids, the premium shall be paid by the Contractor; if subsequent thereto, it shall be paid by the Owner.

Art. 23. Cash Allowances.-The Contractor shall include in the contract price all allowances named in the 
Contract Documents and shall cause the work so covered to be done by such contractors and for such sums as the Architect may direct, the contract sum being adjusted in conformity therewith. The Contractor, in making up his bid, shall add such sums for expenses and profit on account of cash allowances as he deems proper and no demand for expenses or profit other than those included in the contract sum shall be allowed. The Contractor shall not be required to employ for any such work a Subcontractor against whom he has a reasonable objection.

Art. 24. Changes in the Work.-The Owner, without invalidating the contract, may make changes by altering, adding to or deducting from the work, the contract sum being adjusted accordingly. All such work shall be executed under the conditions of the original contract except that any claim for extension of time cansed thereby shall be adjusted at the time of ordering such change.

Except as provided in Articles 9 and I8, no change shall be made unless in pursuance of a written order from the Owner signed or countersigned by the Architect and no claim for an addition to the contract sum shall be valid unless so ordered.

The value of any such change shall be determined in one or more of the following ways:

(a) By Estimate and Acceptance in a lump sum.

(b) By Unit Prices named in the contract or subsequently agreed upon.

(c) By Cost and Percentage or by Cost and a fixed fee.

(d) If none of the above methods is agreed upon, the Contractor, provided he receive an order in writing signed by the Owner and countersigned by the Architect, shall proceed with the work, no appeal to arbitration being allowed from such order to proceed.

In cases (c) and (d), the Contractor shall keep and 
present in such form as the Architect may direct, a correct account of the net cost of labor and materials, together with vouchers. In any case, the Architect shall certify to the amount, including a reasonable profit, due to the Contractor. Pending final determination of value, payments on account of changes shall be made on the Architect's certificate.

Art. 25. Claims for Extras.-If the Contractor claims that any instructions, by drawings or otherwise, involve extra cost under this contract, he shall give the Architect written notice thereof before proceeding to execute the work and, in any event, within two weeks of receiving such instructions, and the procedure shall then be as provided in the last paragraph of Art. 24. No such claim shall be valid unless so made.

Art. 26. Applications for Payments.-The Contractor shall submit to the Architect an application for each payment and, if required, receipts or other vouchers from Subcontractors showing his payments to them for materials and labor as required by Article 44 .

If payments are made on valuation of work done, such application shall be submitted at least ten days before each payment falls due. If required, the Contractor shall before the first application submit to the Architect a schedule of values of the various parts of the work, aggregating the total sum of the contract, divided so as to facilitate payments to subcontractors in accordance with Article 44 (e) made out in such form as the Architect may direct and, if required, supported by evidence as to its correctness. This schedule, when approved by the Architect, shall be used as a basis for certificates of payment, unless it be found to be in error. In applying for payments, the Contractor shall submit a statement based upon this schedule and, if required, itemized in such form as the Architect may direct, showing his right to the payment claimed.

Art. 27. Certificates and Payments.-If the Con- 
tractor has made application as above, the Architect shall, not later than the date when each payment falls due, issue to the Contractor a certificate for such amount as he decides to be properly due.

No certificate issued nor payment made to the Contractor, nor partial or entire use or occupancy of the work by the Owner shall be an acceptance of any work or materials not in accordance with this contract. The making and acceptance of the final payment shall constitute a waiver of all claims by the Owner, otherwise than under Articles 16 and 29 of these conditions or under requirement of the specifications, and of all claims by the Contractor, except those previously made and still unsettled.

Should the Owner fail to pay the sum named in any certificate of the Architect or in any award by arbitration, upon demand when due, the Contractor shall receive, in addition to the sum named in the certificate, interest thereon at the legal rate in force at the place of building.

Art. 28. Payments Withheld.-The Architect may withhold or, on account of subsequently discovered evidence, nullify the whole or a part of any certificate for payment to protect the Owner from loss on account of :

(a) Defective work not remedied.

(b) Claims filed or reasonable evidence indicating probable filing of claims.

(c) Failure of the Contractor to make payments properly to subcontractors or for material or labor.

(d) A reasonable doubt that the contract can be completed for the balance then unpaid.

When all the above grounds are removed certificates shall at once be issued for amounts withheld because of them.

Art. 29. Liens.-Neither the final payment nor any part of the retained percentage shall become due until the Contractor, if required, shall deliver to the Owner 
a complete release of all liens arising out of this contract, or receipts in full in lieu thereof and, if required in either case, an affidavit that the releases and receipts include all the labor and material for which a lien might be filed; but the Contractor may, if any subcontractor refuses to furnish a release or receipt in full, furnish a bond satisfactory to the Owner, to indemnify him against any claim by lien or otherwise. If any lien or claim remain unsatisfied after all payments are made, the Contractor shall refund to the Owner all moneys that the latter may be compelled to pay in discharging such lien or claim, including all costs and a reasonable attorney's fee. Art. 3o. Permits and Regulations.-The Contractor shall obtain and pay for all permits and licenses, but not permanent easements, and shall give all notices, pay all fees, and comply with all laws, ordinances, rules and regulations bearing on the work. If the drawings and specifications are at variance therewith, the Contractor shall notify the Architect in writing before the work is performed and the value of any necessary changes shall be adjusted under Art. 24. If any of the Contractor's work shall be done contrary to such laws, ordinances, rules, and regulations, without such notice, he shall bear all costs arising therefrom.

Art. 3I. Royalties and Patents.-The Contractor shall pay all royalties and license fees and shall defend all suits or claims whatsover for infringement of any patent rights and shall save the Owner harmless from loss on account thereof.

Art. 32. Use of Premises.-The Contractor shall confine his apparatus, the storage of materials and the operations of his workmen to limits indicated by law, ordinances, permits or directions of the Architect and shall not encumber the premises with his materials.

The Contractor shall not load or permit any part of the structure to be loaded with a weight that will endanger its safety. 
The Contractor shall enforce the Architect's instructions regarding signs, advertisements, fires and smoking. Art. 33. Cleaning Up.-The Contractor shall at all times keep the premises free from accumulations of waste material or rubbish caused by his employees or work and at the completion of the work he shall remove all his rubbish from and about the building and all his tools, scaffolding and surplus materials and shall leave his work clean and ready for use. In case of dispute the Owner may remove the rubbish and charge the cost to the several contractors as the Architect shall determine to be just.

Art. 34. Cutting, Patching and Digging.-The Contractor shall do all cutting, fitting or patching of his work that may be required to make its several parts come together properly and fit it to receive or be received by work of other contractors shown upon, or reasonably implied by, the Drawings and Specifications for the completed structure and he shall make good after them, as the Architect may direct.

Any cost caused by defective or ill-timed work shall be borne by the party responsible therefor.

The Contractor shall not endanger any work by cutting, digging or otherwise and shall not cut or alter the work of any other contractor, save with the consent of the Architect.

Art. 35. Delays.-If the Contractor is delayed in the completion of the work by any act or neglect of the Owner or the Architect, or of any employee of either, or by any other contractor employed by the Owner, or by changes ordered in the work, or by strikes, lockouts, fire, unavoidable casualties or any causes beyond the Contractor's control, or by delay authorized by the Architect pending arbitration, or by any cause which the Architect shall decide to justify the delay, then the time of completion shall be extended for such reasonable time as the Architect may decide. 
No such extension shall be made for delay occurring more than seven days before claim therefor is made in writing to the Architect. In the case of a continuing cause of delay, only one claim is necessary.

If no schedule is made under Art. 3, no claim for delay shall be allowed on account of failure to furnish drawings until two weeks after demand for such drawings and not then unless such claim be reasonable.

Art. 36. Owner's Right to Do Work.-If the Contractor should neglect to prosecute the work properly or fail to perform any provision of this contract, the Owner, after three days' written notice to the Contractor, may, without prejudice to any other remedy he may have, make good such deficiencies and may deduct the cost thereof from the payment then or thereafter due the Contractor; provided, however, that the Architect shall approve both such action and the amount charged to the Contractor.

Art. 37. Owner's Right to Terminate Contract.-If the Contractor should be adjudged a bankrupt, or if he should make a general assignment for the benefit of his creditors, or if a receiver should be appointed on account of his insolvency, or if he should, except in cases recited in Article 35, persistently or repeatedly refuse or fail to supply enough properly skilled workmen or proper materials, or if he should fail to make prompt payment to subcontractors or for material or labor, or persistently disregard laws, ordinances or the instructions of the Architect, or otherwise be guilty of a substantial violation of any provisions of the contract, then the Owner; upon the certificate of the Architect that sufficient cause exists to justify such action, may, without prejudice to any other right or remedy and after giving the Contractor seven days' written notice, terminate the employment of the Contractor and take possession of the premises and of all materials, tools and appliances thereon and finish the work by whatever method he may deem 
expedient. In such case the Contractor shall not be entitled to receive any further payment until the work is finished. If the unpaid balance of the contract price shall exceed the expense of finishing the work, including compensation to the Architect for his additional services, such excess shall be paid by the Contractor. If such expense shall exceed such unpaid balance, the Contractor shall pay the difference to the Owner. The expense incurred by the Owner as herein provided, and the damage incurred through the Contractor's default, shall be certified by the Architect.

Art. 38. Contractor's Right to Stop Work or Terminate Contract.-If the work should be stopped under an order of any court, for a period of three months, through no act or fault of the Contractor or of any one employed by him, or if the Owner should fail to pay to the Contractor, within seven days of its maturity and presentation, any sum certified by the Architect or awarded by arbitrators, then the Contractor may, upon three days' written notice to the Owner and the Architect, stop work or terminate this contract and recover from the Owner payment for all work executed and any loss sustained upon any plant or material and reasonable profit and damages.

Art. 39. Damages. - If either party to this contract should suffer damage by delay or otherwise, except as provided in Art. 40, because of any act or neglect of the other party or of any one employed by him, then he shall be reimbursed by the other party for such damage.

Claims under this clause shall be made in writing to the party liable within a reasonable time of the first observance of such damage and not later than the time of final payment, except in case of claims under Article 16 , and shall be adjusted by agreement or arbitration.

Art. 40. Mutual Responsibility of Contractors.Should the Contractor (see Art. I (c)) cause damage 
to any other person (see Art. I (e)) employed on the work, the Contractor agrees, upon due notice, to settle with such person by agreement or arbitration, if such person will so settle. If such person sues the Owner on account of any damage alleged to have been so sustained, the Owner shall notify the Contractor, who shall, at his own expense, defend such proceedings and, if any judgment against the Owner arise therefrom, the Contractor shall pay or satisfy it and pay all costs incurred by the Owner.

The Contractor, if damaged by any person held to the Owner by stipulations such as the above, agrees to settle with such person by agreement or arbitration and in no case to sue the Owner on account of such damage.

Art. 4I. Separate Contracts.-The Owner reserves the right to let other contracts in connection with this work. The Contractor shall afford other contractors reasonable opportunity for the introduction and storage of their materials and the execution of their work and shall properly connect and coordinate his work with theirs.

If any part of the Contractor's work depends for proper execution or results upon the work of any other contractor, the Contractor shall inspect and promptly report to the Architect any defects in such work that render it unsuitable for such proper execution and results. His failure so to inspect and report shall constitute an acceptance of the other contractor's work as fit and proper for the reception of his work, except as to defects which may develop in the other contractor's work after the execution of his work.

To insure the proper execution of his subsequent work the Contractor shall measure work already in place and shall at once report to the Architect any discrepancy between the executed work and the drawings.

Art. 42. Assignment.-Neither party to the Contract 
shall assign the contract without the written consent of the other, nor shall the Contractor assign any moneys due or to become due to him hereunder, without the previous written consent of the Owner.

Art. 43. Subcontracts.-The Contractor shall notify the Architect in writing of the names of subcontractors proposed for the principal parts of the work and for such others as the Architect may direct and shall not employ any that the Architect may within a reasonable time object to as incompetent or unfit.

The Contractor may in his discretion or shall, if so required, submit with his proposal, a list of subcontractors. If the change of any name on such list is required or permitted after signature of agreement, the contract price shall be increased or diminished by the difference between the two bids.

The Architect shall, on request, furnish to any subcontractor, wherever practicable, evidence of the amounts certified to on his account.

The Contractor agrees to be fully responsible to the Owner for the acts or omissions of his subcontractors and of anyone employed either directly or indirectly by him or them and this contractual obligation shall be in addition to the liability imposed by law upon the Contractor for bodily injuries or death through negligence in the cases covered by Article I9 hereof.

Nothing contained in the Contract Documents shall create any contractual relation between any subcontractor and the Owner.

Art. 44. Relations of Contractor and Subcontractor. - The Contractor agrees to bind every subcontractor and every subcontractor agrees to be bound, by the terms of the General Conditions, Drawings and Specifications, as far as applicable to his work, including the following provisions of this Article, unless specifically noted to the contrary in a subcontract approved in writing as adequate by the Owner or Architect. 
The Subcontractor agrees-

(a) To be bound to the Contractor by the terms of the General Conditions, Drawings and Specifications and to assume toward him all the obligations and responsibilities that he, by those documents, assumes toward the Owner.

(b) To submit to the Contractor applications for payment in such reasonable time as to enable the Contractor to apply for payment under Article 26 of the General Conditions.

(c) To make all claims for extras, for extensions of time and for damages for delays or otherwise, to the Contractor in the manner provided in the General Conditions for like claims by the Contractor upon the Owner, except that the time for making claims for extra cost as under Article 25 of the General Conditions is one week.

The Contractor agrees-

(d) To be bound to the Subcontractor by all the obligations that the Owner assumes to the Contractor under the General Conditions, Drawings and Specifications and by all the provisions thereof affording remedies and redress to the Contractor from the Owner.

(e) To pay the Subcontractor, upon the issuance of certificates, if issued under the schedule of values described in Article 26 of the General Conditions, the amount allowed to the Contractor on account of the Subcontractor's work to the extent of the Subcontractor's interest therein.

(f) To pay the Subcontractor, upon the issuance of certificates, if issued otherwise than as in (e), so that at all times his total payments shall be as large in proportion to the value of the work done by him as the total amount certified to the Contractor is to the value of the work done by him.

(g) To pay the Subcontractor to such extent as may be 
provided by the Contract Documents or the subcontract, if either of these provides for earlier or larger payments than the above.

(h) To pay the Subcontractor on demand for his work or materials as far as executed and fixed in place, less the retained percentage, at the time the certificate should issue, even though the Architect fails to issue it for any cause not the fault of the Subcontractor.

(j) To pay the Subcontractor a just share of any fire insurance money received by him, the Contractor, under Article $2 \mathrm{I}$ of the General Conditions.

(k) To make no demand for liquidated damages or penalty for delay in any sum in excess of such amount as may be specifically named in the subcontract.

(1) That no claim for services rendered or materials furnished by the Contractor to the Subcontractor shall be valid unless written notice thereof is given by the Contractor to the Subcontractor during the first ten days of the calendar month following that in which the claim originated.

(m) To give the Subcontractor an opportunity to be present and to submit evidence in any arbitration involving his rights.

(n) To name as arbitrator under Article 45 of the General Conditions the person nominated by the Subcontractor, if the sole cause of dispute is the work, materials, rights or responsibilities of the Subcontractor; or, if of the Subcontractor and any other subcontractor jointly, to name as such arbitrator the person upon whom they agree.

The Contractor and the Subcontractor agree that-

(o) In the matter of arbitration, their rights and obligations and all procedure shall be analogous to those set forth in Article 45 of the General Conditions. Nothing in this Article shall create any obligation on 
the part of the Owner to pay to or to see to the payment of any sums to any Subcontractor.

Art. 45. Arbitration.-Subject to the provisions of Article Io, all questions in dispute under this contract shall be submitted to arbitration at the choice of either party to the dispute.

The general procedure shall conform to the laws of the State in which the work lies and wherever permitted by law the decision of the arbitrators may be filed in court to carry it into effect.

The demand for arbitration shall be filed in writing with the Architect, in the case of an appeal from his decision, within ten days of its receipt and in any other case within a reasonable time after cause thereof and in no case later than the time of final payment, except as to questions arising under Article I6. If the Architect fails to make a decision within a reasonable time, an appeal to arbitration may be taken as if his decision had been rendered against the party appealing.

The parties may agree upon one arbitrator; otherwise there shall be three, one named in writing by each party and the third chosen by these two arbitrators or, if they fail to select a third within ten days he shall be chosen by the presiding officer of the nearest Bar Association. Should the party demanding arbitration fail to name an arbitrator within ten days of his demand, his right to arbitration shall lapse. Should the other party fail to choose an arbitrator within such ten days, the Architect shall appoint such arbitrator. Should either party refuse or neglect to supply the arbitrators with any papers or information demanded in writing, the arbitrators are empowered by both parties to take ex parte proceedings.

The arbitrators shall act with promptness. The decision of any two shall be binding on all parties to the dispute. The decision of the arbitrators upon any question subject to arbitration under this contract shall be a condition precedent to any right of legal action. 
The arbitrators, if they deem that the case demands it, are authorized to award to the party whose contention is sustained such sums as they shall deem proper for the time, expense and trouble incident to the appeal and, if the appeal was taken without reasonable cause, damages for delay. The arbitrators shall fix their own compensation, unless otherwise provided by agreement and shall assess the costs and charges of the arbitration upon either or both parties.

The award of the arbitrators must be in writing, and, if in writing, shall not be open to objection on account of the form of the proceedings or the award.

\section{THE STANDARD FORM OF BOND}

\section{ISSUED BY THE AMERICAN INSTITUTE OF ARCHITECTS}

This form has been approved by the National Association of Builders' Exchanges, The National Association of Master Plumbers, and the National Association of Master Steam and Hot Water Fitters.

Second Edition, Copyright 1915 by the American Institute of Architects, The Octagon, Washington, D. C.

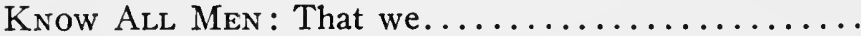

(Here insert the name and address or legal title of the Contractor.)

hereinafter called the Principal, and...

(Here insert the name and address or legal title of one or more sureties.)

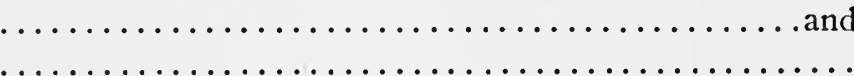

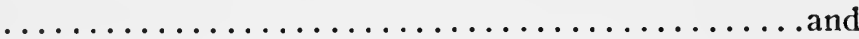
hereinafter called the Surety or Sureties are held and

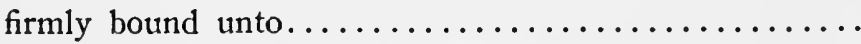

(Here insert the name and address or legal title of the Owner.)

hereinafter called the Owner, in the sum of

$(\$ \ldots \ldots \ldots)$ 
for the payment whereof the Principal and the Surety or Sureties bind themselves, their heirs, executors, administrators, successors and assigns, jointly and severally, firmly, by these presents.

Whereas, the Principal has, by means of a written Agree-

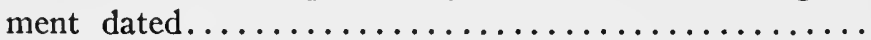
. entered into a contract with the Owner for

a copy of which Agreement is by reference made a part hereof ;

Now, Therefore, the Condition of this Obligation is such that if the Principal shall faithfully perform the Contract on his part, and satisfy all claims and demands, incurred for the same, and shall fully indemnify and save harmless the Owner from all cost and damage which he may suffer by reason of failure so to do, and shall fully reimburse and repay the Owner all outlay and expense which the Owner may incur in making good any such default, and shall pay all persons who have contracts directly with the Principal for labor or materials, then this obligation shall be null and void; otherwise it shall remain in full force and effect.

Provided, however, that no suit, action or proceeding by reason of any default whatever shall be brought on this Bond after...........months from the day on which the final payment under the Contract falls due.

And Provided, that any alterations which may be made in the terms of the Contract, or in the work to be done under it, or the giving by the Owner of any extension of time for the performance of the Contract, or any other forbearance on the part of either the Owner or the Principal to the other shall not in any way release the Principal and the Surety or Sureties, or either or any of them, their heirs, executors, administrators, successors or assigns from their liability hereunder, notice to the 
Surety or Sureties of any such alteration, extension or forbearance being hereby waived.

Signed and Sealed this........ day of........ I9... In Presence of

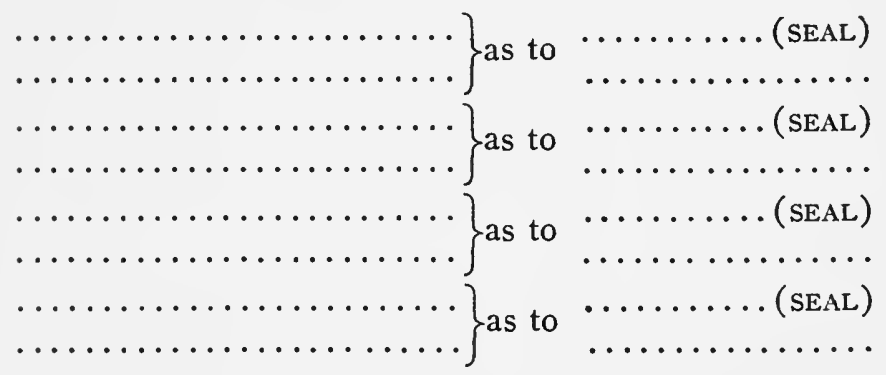

\section{THE STANDARD FORM OF SUBCONTRACT}

For use in connection with the General Conditions of the Contract as issued by the American Institute of Architects.

This form has been approved by the National Association of Builders' Exchanges, The National Association of Master Plumbers, and the National Association of Master Steam and Hot Water Fitters.

Copyright 1915 by the American Institute of Architects, The Octagon, Washington, D. C.

\section{THIS AGREEMENT, made this} I9 by and between

the Subcontractor and

hereinafter called the Contractor.

WITNESSETH, That the Subcontractor and Contractor for the considerations hereinafter named agree as follows :

Section I. The Subcontractor agrees to furnish all material and perform all work as described in Section 2 hereof for

for

$$
\text { (Here name the kind of building.) }
$$

(Here insert the name of the Owner.)

hereinafter called the Owner, at

(Here insert the location of the work.) 
in accordance with the General Conditions of the Contract between the Owner and the Contractor, and in accordance with the Drawings and the Specifications prepared by

hereinafter called the Architect, all of which General Conditions, Drawings and Specifications signed by the parties hereto or identified by the Architect, form a part of a Contract between the Contractor and the Owner dated and hereby become a part of this Contract.

Section 2. The Subcontractor and the Contractor agree that the materials to be furnished and work to be done by the Subcontractor are

(Here insert a precise description of the work, preferably by reference to the numbers of the Drawings and the pages of the Specifications.)

Section 3. The Subcontractor agrees to complete the several portions and the whole of the work herein sublet by the time or times following:

(Here insert the date or dates and if there be liquidated damages state them.)

Section 4. The Contractor agrees to pay the Subcontractor for the performance of his work the sum of

in current funds, subject to additions and deductions for changes as may be agreed upon, and to make payments on account thereof in accordance with Section 5 hereof.

Section 5. The Contractor and Subcontractor agree to be bound by the terms of the General Conditions, Drawings and Specifications as far as applicable to this subcontract, including the provisions of Article 44 of the General Conditions of the Contract, as follows:

The Subcontractor agrees:

(a) To be bound to the Contractor by the terms of the General Conditions, Drawings and Specifications, and to assume toward him all the obligations and responsibilities that he, by those documents, assumes toward the Owner. 
(b) To submit to the Contractor applications for payment in such reasonable time as to enable the Contractor to apply for payment under Article 26 of the General Conditions.

(c) To make all claims for extras, for extensions of time and for damages for delays or otherwise, to the Contractor in the manner provided in the General Conditions for like claims by the Contractor upon the Owner, except that the time for making claims for extra cost as under Article 25 of the General Conditions, is one week.

The Contractor agrees:

(d) To be bound to the Subcontractor by all the obligations that the Owner assumes to the Contractor under the General Conditions, Drawings and Specifications, and by all the provisions thereof affording remedies and redress to the Contractor from the Owner.

(e) To pay the Subcontractor, upon the issuance of certificates, if issued under the schedule of values described in Article 26 of the General Conditions, the amount allowed to the Contractor on account of the Subcontractor's work to the extent of the Subcontractor's interest therein.

( $f$ ) To pay the Subcontractor, upon the issuance of certificates, if issued otherwise than as in $(e)$, so that at all times his total payments shall be as large in proportion to the value of the work done by him as the total amount certified to the Contractor is to the value of the work done by him.

(g) To pay the Subcontractor to such extent as may be provided by the Contract Documents or the Subcontract, if either of these provides for earlier or larger payments than the above.

(h) To pay the Subcontractor on demand for his work or materials as far as executed and fixed in place, less the retained percentage, at the time the certificate should issue, even though the Architect fails to issue it for any cause not the fault of the Subcontractor.

(j) To pay the Subcontractor a just share of any fire insurance money received by him, the Contractor, under Article 2I of the General Conditions.

(k) To make no demand for liquidated damages or penalty for delay in any sum in excess of such amount as may be specifically named in the Subcontract.

(l) That no claim for services rendered or materials furnished by the Contractor to the Subcontractor shall be valid unless written notice thereof is given by the Contractor to the Subcontractor during the first ten days of the calendar month following that in which the claim originated. 
(m) To give the Subcontractor an opportunity to be present and to submit evidence in any arbitration involving his rights.

(n) To name as arbitrator under Article 45 of the General Conditions, the person nominated by the Subcontractor if the sole cause of dispute is the work, materials, rights or responsibilities of the Subcontractor; or, if of the Subcontractor and any other Subcontractor jointly, to naine as such arbitrator the person upon whom they agree.

The Contractor and the Subcontractor agree that:

(o) In the matter of arbitration their rights and obligations and all procedure shall be analogous to those set forth in Article 45 of the General Conditions.

Nothing in this Article shall create any obligation on the part of the Owner to pay to or to see to the payment of any sums to any Subcontractor.

Section 6.

Finally.-The Subcontractor and Contractor, for themselves, their heirs, successors, executors, administrators and assigns, do hereby agree to the full performance of the covenants herein contained.

In Witness WhEREoF they have hereunto set their hands the day and date first above written.

In Presence of

Subcontractor.

Contractor.

\section{STANDARD FORM OF ACCEPTANCE OF SUBCONTRACTOR'S PROPOSAL} For use in connection with the Standard Documents of the American

This form has been approved by the National Association of Builders' Exchanges, The National Association of Master Plumbers, and the National Association of Master Steam and Hot Water Fitters. Copyright 1915 by the American Institute of Architects, The Octagon,

DEAR Sir: Having entered into a contract with

(Here insert the name and address or corporate title of the Owner.) 
for the erection of

(Here insert the kind of work and the place at which it is to be erected.) in accordance with plans and specifications prepared by (Here insert the name and address of the Architect.)

and in accordance with the General Conditions of the Contract prefixed to the specifications, the undersigned hereby accepts your proposal of

(Here insert date.)

to provide all the materials and do all the work of

(Here insert the kind of work to be done, as plumbing, roofing, etc., accurately describing by number, page, etc., the drawings and specifications governing such work.)

The Undersigned agrees to pay you in current funds for the faithful performance of the subcontract established by this acceptance of your proposal the sum of

(\$

Our relations in respect of this subcontract are to be governed by the plans and specifications named above, by the General Conditions of the Contract as far as applicable to the work thus sublet and especially by Article 44 of those conditions printed on the reverse hereof.

Very truly yours,

\section{AUTHORITY TO EXECUTE A CONTRACT OR BOND}

When the Contractor, the Owner or the Surety is a corporation, it is important that any Agreement or Bond executed by such corporation should be accompanied by a certificate, such as the following, showing that power so to sign is duly vested in those signing:

"At a meeting of the Board of Directors of the......

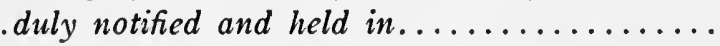
on.........., I9..., a quorum being present it was 
VoTED: That be and he is hereby authorized and directed in the name and behalf of this Corporation, and under its corporate seal, to execute and deliver a contract with.............

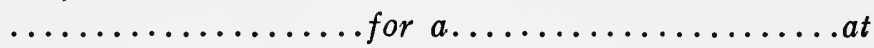
............... for the sum of $\$ \ldots . . . \ldots \ldots$. said contract to be in such form and subject to such conditions as said....................... shall see fit. And said..................... is hereby further authorized and directed in the name and behalf of this Corporation and under its corporate seal, to execute and deliver to said Ozener any bond or bonds he may see fit for the performance of said contract by this Corporation.

A True Copy.

Attest:

Secretary.

The same form, with omission of last sentence, applies to the Owner.

\section{FORM OF INVITATION TO SUBMIT A PROPOSAL}

DEAR SIR: You are invited to submit a proposal for ............... Drawings, Specifications and other information may be procured from this office on and after All documents must be returned to this office not later than ....................

To be entitled to consideration the proposal must be made upon the form provided by the Architect, which must be fully completed in accordance with the accompanying "Instructions to Bidders" and must be delivered to this office not later than....

Very truly yours, 


\section{FORM OF INSTRUCTIONS TO BIDDERS}

Proposals, to be entitled to consideration, must be made in accordance with the following instructions:

Proposals shall be made upon the form provided therefor, and all blank spaces in the form shall be fully filled; numbers shall be stated both in writing and in figures; the signature shall be in long hand; and the completed form shall be without interlineation, alteration or erasure.

Proposals shall not contain any recapitulation of the work to be done. No oral, telegraphic or telephonic proposals or modifications will be considered.

Proposals shall be addressed to the Owner, in care of the Architect, and shall be delivered to the Architect enclosed in an opaque sealed envelope addressed to him, marked "Proposal" and bearing the title of the work and the name of the Bidder.

Should a bidder find discrepancies in, or omissions from, the drawings or documents, or should he be in doubt as to their meaning, he should at once notify the Architect, who will send a written instruction to all bidders. Neither Owner nor Architect will be responsible for any oral instructions.

Before submitting a proposal, bidders should carefully examine the drawings and specifications, visit the site or work, fully inform themselves as to all existing conditions and limitations and shall include in the Proposal a sum to cover the cost of all items included in the Contract.

The competency and responsibility of bidders and of their proposed subcontractors will be considered in making the award. The Owner does not obligate himself to accept the lowest or any other bid.

Provision will be made in the Agreement for payments on account in the following words: (Insert the provision).

Any Bulletins issued during the time of bidding are to be covered in the proposal and in closing a contract they will become a part thereof. 


\section{FORM OF PROPOSAL}

(The Proposal should be dated and addressed to the Owner in care of the Architect.)

DEAR SIR: Having carefully examined the Instructions to Bidders, the General Conditions of the Contract

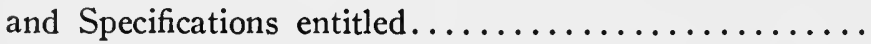

(Here insert the caption descriptive of the work as used therein.)

and the Drawings, similarly entitled, numbered........ as well as the premises and the conditions affecting the work, the Undersigned proposes to furnish all materials

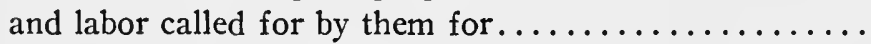

(Here insert, in case all the work therein described is to be covered by one contract, "the entire work." In case of a partial contract insert name of the trade or trades to be covered and the numbers of the pages of the Specifications on which the work is described.)

in accordance with the said documents for the sum of $\ldots \ldots \ldots$......... Dollars $(\$ \ldots . .$.$) and to execute a$ contract for the above work, for the above stated compensation in the form of the Standard Agreement of the American Institute of Architects (second edition), provided that he be notified of the acceptance of this proposal within ......... days of the time set for the submission of bids.

Very truly yours,

SUGGESTIONS TO ARCHITECTS USING THE ABOVE FORM OF PROPOSAL

The above form includes only such statements as will probably be required in any Proposal. Additions will usually have to be made to it. Suggestions suited to certain conditions are offered in the following notes.

If the Bidder is to name the time required for completing the work, insert such a clause as the following:

The Undersigned agrees, if awarded the Contract, to complete it within...........days, Sundays and whole holidays not included. 
If liquidated damages are to be required, insert the following:

And further agrees that, from the compensation otherwise to be paid, the Owner may retain the sum of....... dollars $(\$ \ldots . .$.$) ) for each day thereafter, Sundays and$ whole holidays not included, that the work remains uncompleted, which sum is agreed upon as the proper measure of liquidated damages which the Owner will sustain per diem by the failure of the undersigned to complete the work at the time stipulated, and this sum is not to be construed as in any sense a penalty.

If a bond is required, insert the following:

The Undersigned agrees, if awarded the Contract, to execute and deliver to the Architect within........days after the signing of the Contract, a satisfactory bond in the form issued by the American Institute of Architects (second edition) and in the sum of .........., extending from the time of signature for .........months from the day on which the final payment under the contract falls due, and further agrees that if such bond be not required, he will deduct from the proposal price the sum of....... dollars $(\$ \ldots . . . .$.$) .$

If a certified check is required, the following clause should be inserted:

The Undersigned further agrees that the certified check payable to.............. Owner, accompanying this proposal, is left in escrow with the Architect; that its amount is the measure of liquidated damages which the Owner will sustain by the failure of the Undersigned to execute and deliver the above named Agreement and bond, and that if the Undersigned defaults in executing that Agreement within..........days of written notification of the award of the contract to him or in furnishing the Bond within..........days thereafter, then the check shall become the property of the Owner, but if this proposal is not accepted within...........days of the time set for the submission of bids, or if the Undersigned 
executes and delivers said Contract and Bond, the check shall be returned to him on receipt therefor.

If alternative proposals are required, they should be set forth, as for example,

Should............ be substituted for........... the Undersigned agrees to deduct (or will require the addition of).......... dollars (\$.......) from (or to) the proposed sum.

If unit prices are required as a part of the proposal, they should be set forth as, for example:

The Undersigned agrees that work added shall be computed at the following prices, and that work omitted shall be computed at ........per cent less than these prices. Concrete foundations................per cubic yard,

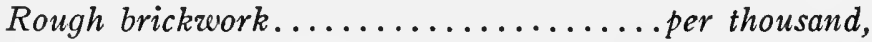

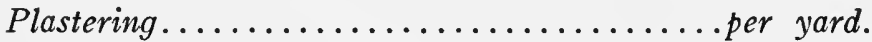

If the names of subcontractors whom the Contractor proposes to employ are required as a part of the Proposal this requirement should be set forth, as, for example:

In case of obtaining the award the Undersigned will employ, subject to the Architect's approval, subcontractors in each of the several trades selected from the following list (one or more names must be inserted for each trade):

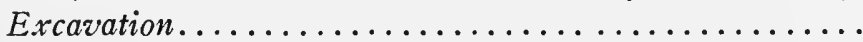

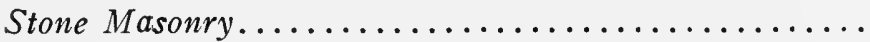

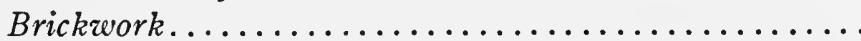
etc., etc. 


\title{
APPENDIX C
} (Published by special permission and courtesy of the American Institute
of Architects.)

\section{THE AMERICAN INSTITUTE OF ARCHITECTS}

\author{
PROFESSIONAL PRACTICE OF ARCHITECTS \\ SCHEDULE OF PROPER MINIMUM CHARGES
}

I. The architect's professional services consist of the necessary conferences, the preparation of preliminary studies, working drawings, specifications, large scale and full size detail drawings, and of the general direction and supervision of the work, for which, except as hereinafter mentioned, the minimum charge, based upon the total cost $*$ of the work complete is six per cent.

2. On residential work, alterations to existing buildings, monuments, furniture, decorative and cabinet work and landscape architecture, it is proper to make a higher charge than above indicated.

3. The architect is entitled to compensation for articles purchased under his direction, even though not designed by him.

4. If an operation is conducted under separate contracts, rather than under a general contract, it is proper to charge a special fee in addition to the charges mentioned elsewhere in this schedule.

5. Where the architect is not otherwise retained, consultation fees for professional advice are to be paid in

* The total cost is to be interpreted as the cost of all materials and labor necessary to complete the work, plus contractors' profits and expenses, as such cost would be if all materials were new and all labor fully paid, at market prices current when the work was ordered. 
proportion to the importance of the question involved and services rendered.

6. Where heating, ventilating, mechanical, structural, electrical and sanitary problems are of such a nature as to require the services of a specialist, the owner is to pay for such services. Chemical and mechanical tests and surveys, when required, are to be paid for by the owner.

7. Necessary traveling expenses are to be paid by the owner.

8. If, after a definite scheme has been approved, changes in drawings, specifications or other documents are required by the owner; or if the architect be put to extra labor or expense by the delinquency or insolvency of a contractor, the architect shall be paid for such additional services and expense.

9. Payments to the architect are due as his work progresses in the following order: Upon completion of the preliminary studies, one-fifth of the entire fee; upon completion of specifications and general working drawings (exclusive of details), two-fifths additional, the remainder being due from time to time in proportion to the amount of service rendered. Until an actual estimate is received, charges are based upon the proposed cost of the work and payments received are on account of the entire fee.

Io. In case of the abandonment or suspension of the work, the basis of settlement is to be as follows: For preliminary studies, a fee in accordance with the character and magnitude of the work; for preliminary studies, specifications and general working drawings (exclusive of details), three-fifths of the fee for complete services.

II. The supervision of an architect (as distinguished from the continuous personal superintendence which may be secured by the employment of a clerk-of-theworks or superintendent of construction) means such inspection by the architect or his deputy, of work in stu- 
dios and shops or a building or other work in process of erection, completion or alteration, as he finds necessary to ascertain whether it is being executed in general conformity with his drawings and specifications or directions. He has authority to reject any part of the work which does not so conform and to order its removal and reconstruction. He has authority to act in emergencies that may arise in the course of construction, to order necessary changes, and to define the intent and meaning of the drawings and specifications. On operations where a clerk-of-the-works or superintendent of construction is required, the architect shall employ such assistance at the owner's expense.

12. Drawings and specifications, as instruments of service, are the property of the architect.

As revised at the Washington Convention, December I5-17, I908.

OfFICE OF THE Secretary, The Octagon, Washington, D. C.

February, I9I4 


\section{APPENDIX D}

A. I. A. Document I07

(Published by special permission and courtesy of the American Institute of Architects.)

\section{A CIRCULAR OF ADVICE}

Relative to Principles of Professional Practice

\section{THE CANONS OF ETHICS}

THE AMERICAN INSTITUTE OF ARCHITECTS

Office of the Secretary, Tfie Octagon, Washington, D. C., February, igrs.

A CIRCULAR OF ADVICE

The American Institute of Architects, seeking to maintain a high standard of practice and conduct on the part of its members as a safeguard of the important financial, technical and esthetic interests entrusted to them, offers the following advice relative to professional practice:

The profession of architecture calls for men of the highest integrity, business capacity and artistic ability. The architect is entrusted with financial undertakings in which his honesty of purpose must be above suspicion; he acts as professional adviser to his client and his advice must be absolutely disinterested; he is charged with the exercise of judicial functions as between client and contractors and must act with entire impartiality; he has moral responsibilities to his professional associates and subordinates; finally, he is engaged in a profession which carries with it grave responsibility to the public. These duties and responsibilities cannot be properly discharged unless his motives, conduct and ability are such as to command respect and confidence.

No set of rules can be framed which will particularize 260 
all the duties of the architect in his various relations to his clients, to contractors, to his professional brethren, and to the public. The following principles should, however, govern the conduct of members of the profession and should serve as a guide in circumstances other than those enumerated.

I. On the Architect's Status.-The architect's relation to his client is primarily that of professional adviser; this relation continues throughout the entire course of his service. When, however, a contract has been executed between his client and a contractor by the terms of which the architect becomes the official interpreter of its conditions and the judge of its performance, an additional relation is created under which it is incumbent upon the architect to side neither with client nor contractor, but to use his powers under the contract to enforce its faithful performance by both parties. The fact that the architect's payment comes from the client does not invalidate his obligation to act with impartiality to both parties.

2. On Preliminary Drawings and Estimates.-The architect at the outset should impress upon the client the importance of sufficient time for the preparation of drawings and specifications. It is the duty of the architect to make or secure preliminary estimates when requested, but he should acquaint the client with their conditional character and inform him that complete and final figures can be had only from complete and final drawings and specifications. If an unconditional limit of cost be imposed before such drawings are made and estimated, the architect must be free to make such adjustments as seem to him necessary. Since the architect should assume no responsibility that may prevent him from giving his client disinterested advice, he should not, by bond or otherwise, guarantee any estimate or contract.

3. On Superintendence and Expert Services.-On all work except the simplest, it is to the interest of the owner to employ a superintendent or clerk of the works. In 
many engineering problems and in certain specialized esthetic problems, it is to his interest to have the services of special experts and the architect should so inform him. The experience and special knowledge of the architect make it to the advantage of the owner that these persons, although paid by the owner should be selected by the architect under whose direction they are to work.

4. On the Architect's Charges.-The Schedule of Charges of the American Institute of Architects is recognized as a proper minimum of payment. The locality or the nature of the work, the quality of services to be rendered, the skill of the practitioner or other circumstances frequently justify a higher charge than that indicated by the Schedule.

5. On Payment for Expert Service.-The architect when retained as an expert, whether in connection with competitions or otherwise, should receive a compensation proportionate to the responsibility and difficulty of the service. No duty of the architect is more exacting than such service, and the honor of the profession is involved in it. Under no circumstances should experts knowingly name prices in competition with each other.

6. On Selection of Bidders or Contractors.-The architect should advise the client in the selection of bidders and in the award of the contract. In advising that none but trustworthy bidders be invited and that the award be made only to contractors who are reliable and competent, the architect protects the interests of his client.

7. On Duties to the Contractor.-As the architect decides whether or not the intent of his plans and specifications is properly carried out, he should take special care to see that these drawings and specifications are complete and accurate, and he should never call upon the contractor to make good oversights or errors in them nor attempt to shirk responsibility by indefinite clauses in the contract or specifications.

8. On Engaging in the Building Trades.-The architect 
should not directly or indirectly engage in any of the building trades. If he has any financial interest in any building material or device, he should not specify or use it without the knowledge and approval of his client.

9. On Accepting Commissions or Favors.-The architect should not receive any commission or any substantial service from a contractor or from any interested person other than his client.

Io. On Encouraging Good Workmanship.-The large powers with which the architect is invested should be used with judgment. While he must condemn bad work, he should commend good work. Intelligent initiative on the part of craftsmen and workmen should be recognized and encouraged and the architect should make evident his appreciation of the dignity of the artisan's function.

II. On Offering Services Gratuitously.-The seeking out of a possible client and the offering to him of professional services on approval and without compensation, unless warranted by personal or previous business relations, tends to lower the dignity and standing of the profession and is to be condemned.

12. On Advertising.-Advertising tends to lower the dignity of the profession and is therefore condemned.

13. On Signing Buildings and Use of Titles.-The display of the architect's name upon a building under construction is condemned, but the unobtrusive signature of buildings after completion has the approval of the Institute. The use of initials designating membership in the Institute is proper in connection wth any professional service and is to be encouraged as helping to make known the nature of the honor they imply.

I4. On Competitions.-An architect should not take part in a competition as a competitor or juror unless the competition is to be conducted according to the best practice and usage of the profession, as evidenced by its having received the approval of the Institute, nor should he continue to act as professional adviser after it has been 
determined that the program cannot be so drawn as to receive such approval. When an architect has been authorized to submit sketches for a given project, no other architect should submit sketches for it until the owner has taken definite action on the first sketches, since, as far as the second architect is concerned, a competition is thus established. Except as an authorized competitor, an architect may not attempt to secure work for which a competition has been instituted. He may not attempt to influence the award in a competition in which he has submitted drawings. He may not accept the commission to do the work for which a competition has been instituted if he has acted in an advisory capacity either in drawing the program or in making the award.

15. On Injuring Others.-An architect should not falsely or maliciously injure, directly or indirectly, the professional reputation, prospects or business of a fellow architect.

I6. On Undertaking the Work of Others.-An architect should not undertake a commission while the claim for compensation or damages or both, of an architect previously employed and whose employment has been terminated remains unsatisfied, unless such claim has been referred to arbitration or issue has been joined at law; or unless the architect previously employed neglects to press his claim legally; nor should he attempt to supplant a fellow architect after definite steps have been taken toward his employment.

I7. On Duties to Students and Draughtsmen.-The architect should advise and assist those who intend making architecture their career. If the beginner must get his training solely in the office of an architect, the latter should assist him to the best of his ability by instruction and advice. An architect should urge his draughtsmen to avail themselves of educational opportunities. He should, as far as practicable, give encouragement to all worthy agencies and institutions for architectural educa- 
tion. While a thorough technical preparation is essential for the practice of architecture, architects cannot too strongly insist that it should rest upon a broad foundation of general culture.

18. On Duties to the Public and to Building Authorities.-An architect should be mindful of the public welfare and should participate in those movements for public betterment in which his special training and experience qualify him to act. He should not, even under his client's instructions, engage in or encourage any practices contrary to law or hostile to the public interest; for as he is not obliged to accept a given piece of work, he cannot, by urging that he has but followed his client's instructions, escape the condemnation attaching to his acts. An architect should support all public officials who have charge of building in the rightful performance of their legal duties. He should carefully comply with all building laws and regulations, and if any such appear to him unwise or unfair, he should endeavor to have them altered.

I9. On Professional Qualifications.-The public has the right to expect that he who bears the title of architect has the knowledge and ability needed for the proper invention, illustration and supervision of all building operations which he may undertake. Such qualifications alone justify the assumption of the title of architect.

\section{THE CANONS OF ETHICS}

The following Canons are adopted by the American Institute of Architects as a general guide, yet the enumeration of particular duties should not be construed as a denial of the existence of others equally important although not specially mentioned. It should also be noted that the several sections indicate offenses of greatly varying degrees of gravity.

It is unprofessional for an architect- 
I. To engage directly or indirectly in any of the building trades.

2. To guarantee an estimate or contract by bond or otherwise.

3. To accept any commission or substantial service from a contractor or from any interested party other than the owner.

4. To advertise.

5. To take part in any competition which has not received the approval of the Institute or to continue to act as professional adviser after it has been determined that the program cannot be so drawn as to receive such approval.

6. To attempt in any way, except as a duly authorized competitor, to secure work for which a competition is in progress.

7. To attempt to influence, either directly or indirectly, the award of a competition in which he is a competitor.

8. To accept the commission to do the work for which a competition has been instituted if he has acted in an advisory capacity, either in drawing the program or in making the award.

9. To injure falsely or maliciously, directly or indirectly, the professional reputation, prospects or business of a fellow architect.

Io. To undertake a commission while the claim for compensation, or damages, or both, of an architect previously employed and whose employment has been terminated remains unsatisfied, until such claim has been referred to arbitration or issue has been joined at law, or unless the architect previously employed neglects to press his claim legally.

I I. To attempt to supplant a fellow architect after definite steps have been taken toward his employment, e. g., by submitting sketches for a project for which another architect has been authorized to submit sketches. 
I2. To compete knowingly with a fellow architect for employment on the basis of professional charges.
Adopted December 14-16, 1909.
Revised December 10-12, I9I2. 


\section{APPENDIX E}

(Published by special permission and courtesy of the New York Chapter of the American Institute of Architects.)

SCHEDULE OF CHARGES APPROVED BY THE NEW YORK CHAPTER OF THE AMERICAN INSTITUTE OF ARCHITECTS

SUPPLEMENTARY TO THE STATEMENT OF PROFESSIONAL PRACTICE OF ARCHITECTS AND SCHEDULE OF PROPER MINIMUM CHARGES OF THE AMERICAN INSTITUTE OF ARCHITECTS

ADOPTED DEC. 15-17, 1908 .

The New York Chapter of the American Institute of Architects as a professional body, recognizing that the value of an Architect's services varies with his experience, ability, and the locality and character of the work upon which he is employed, does not establish a rate of compensation binding upon its members, but it is the judgment of the New York Chapter that for full professional services adequately rendered, an architect practicing in the City of New York should receive as reasonable remuneration therefor at least the compensation mentioned in the following schedule of charges:

I. The Architect's professional services consist of the necessary conferences, the preparation of preliminary studies, working drawings, specifications, large scale and full size detail drawings, and of the general direction and supervision of the work, for which, except as hereinafter mentioned, the minimum charge, based upon the total cost of the work complete, as established by the American Institute of Architects, 1908, is: . . . . . 6 per cent. 
2. Residential Work:

Private dwellings within the limits of the City of New York,

On the first $\$ 50,000$ of cost . . 8 per cent. On the balance of cost, the minimum fee of . .

Private dwellings outside of the City of New York, including stables and other dependencies.

On the first $\$ 50,000$ of cost . . Io per cent.

On the balance of cost . . . . 8 per cent.

The graduated commission applies only to the above two classes of residential work.

3. Monumental, decorative and landscape work, special interior and cabinet work, alterations to existing buildings.

In all cases whether in connection with Federal, Municipal, or other work . . . . Io per cent.

4. Designs for fabrics, furniture and fixtures, lighting fixtures, and special decorative work 15 per cent.

5. Articles not designed by the architect but purchased under his direction . . . . . 6 per cent.

6. All disbursements for travelling expenses, measurements, surveys, fees for expert advice when requested or sanctioned by the client, and the cost of all prints, to be paid for by the client.

7. All of the above charges are subject to increase by special arrangement, where the cost of the work is small or the conditions unusually difficult.

8. By special interiors and cabinet work, is meant that part of the work which is individual, requiring special study and drawings for each room or each feature thereof, as distinguished from the work which is repetitious and which can be executed from typical drawings and general specifications.

9. The supervision of an architect does not guarantee the performance of the contract by the contractor, 
270 LAW OF ARCHITECTURE AND BUILDING

or insure the client against defective work thereunder.

I0. The Schedule of the American Institute of Architects, shall govern in all cases not covered by the foregoing Schedule.

F. H. Holden, Secretary, New York Chapter, A. I. A.

Adopted, January 8th, I9IO. Copyright 1910, by the New York Chapter of the American Institute of 


\section{FORMS}





\section{FORMS}

(See also Appendix B)

As stated in the introduction, it has seemed best to give, in addition to the forms included in Appendix B, a number of the more usual and important forms required in lien proceedings. The forms here given deal primarily with the early steps, preliminary to or upon the institution of a lien action. For other forms dealing with later proceedings, or forms less intimately connected with the rights of the architect, owner and contractor, reference may be made to any standard form books or special text books on lien litigation. The following forms are selected largely from forms used in actual litigation. They should, of course, be adapted to the special circumstances of the cases in which use may be made of them.

\section{NOTICE OF LIEN (A) AND COMPLAINT (B)}

(in action to foreclose lien where work has been performed at request of lessee of a portion of premises of an office building, apartment house or similar structure, and where architect has furnished special materials, in addition to preparing plans and specifications.) 


\section{(A) NOTICE OF LIEN}

To the Clerk of the County of New York, State of New York:-

TAKe Notice, that I, A...., residing in the City of ....., County of ...., and State of ...., with offices at No............ Avenue, Borough of Manhattan, City, County and State of New York, have and claim a lien for the principal and interest of the value and agreed price of the labor and materials hereinafter mentioned, upon the real property and upon the improvements hereinafter mentioned, pursuant to the Lien Law and the Acts amendatory thereof and supplemental thereto; and I do further state and allege as follows, to wit, that

I. The name of the owner of the real property against whose interest a lien is claimed is, B...... Its address and principal office is at No........... Avenue, in the Borough of Manhattan, City and State of New York. A lien is likewise claimed against the fee of said property and the interest therein, if any, of C..... and D..... all as hereinafter stated.

II. The names of the corporation and of the person by which and by whom I was employed and to which and to whom I furnished the labor and materials are: C.... and D.... The address of said C... is No. .......... Avenue, Borough of Manhattan, City and State of New York, and the address of said D.... is, No. .......... Avenue, Borough of Manhattan, City and State of New York.

III. The labor performed, materials furnished and the agreed prices thereof are as follows:

Services as architect in the superintendence and preparation of plans and specifications, the preparation and furnishing of designs for and the furnishing and installation of especially designed electric-lighting fixtures in connection with, and the superintendence and supervision 
as architect of, certain alterations and improvements in and to and the out-fitting of the offices occupied and leased by C.... and situate on the Sixth floor of the building known as No........... Avenue, Borough of Manhattan, City and State of New York, the foregoing including the supervision by me and the superintendence by me as architect of all of said work, the making of said alterations, the designing and installation of said fixtures, the carrying out of the work done pursuant to said plans and specifications, and all of the details of the work above referred to.

Said services were performed at the request of said C...., and D..., and for said services, said C.... and said D.... jointly and severally expressly covenanted and agreed to make payment to me as follows, viz.: For so much of said services as were exclusive of the furnishing of the said lighting fixtures the sum of ..... dollars; and for the furnishing and installation of said lighting fixtures and the superintendence thereof, the additional sum of ..... dollars.

IV. The amount unpaid and owing to me for said labor and materials aforesaid at the time of the filing of this Notice of Lien is the sum of ...... dollars. Said labor and materials were and are reasonably worth and of the reasonable value of the said sum of ...... dollars.

V. On information and belief, the time when the first item of work was performed was the 2oth day of September, 1913, and the time when the last item of work was performed was the 7 th day of November, 19r3. Ninety days have not elapsed since the last item of said work, for which this lien is claimed, was performed. The work on said premises is entirely performed at the present time.

VI. On information and belief, the property subject to this lien, and upon which I claim a lien, is described as follows, viz:

All that plot, piece or parcel of land in the City, 
County and State of New York, with the buildings and improvements thereon erected and situate, bounded and described as follows, to wit:

(Insert detailed description by metes and bounds, with diagram if practicable.)

VII. This lien is claimed upon the fee of said' premises and upon the buildings and improvements thereon erected, situate, or made, with any and all appurtenances thereto and against any and all interest and estates of said B.... and C.... and D...., and any and all of them, in or to or concerning said premises and the said improvements and appurtenances.

VIII. Said labor was performed and said materials were furnished with the express knowledge, consent and approval of said B...., the owner of the fee of said premises.

IX. All the labor performed and materials furnished herein have been performed and furnished in the manner and for the purposes herein set forth, and for the improvement of the said real property.

Dated, New York City, January -, I9I4.

A....,

Lienor.

$\left.\begin{array}{l}\text { State of New York } \\ \text { County of New York }\end{array}\right\}$ ss.

A...., being duly sworn, deposes and says: that he is the claimant and lienor mentioned in the foregoing Notice of Lien; that he has read said Notice, and knows the contents thereof, and that the same is true of his own knowledge, except as to the matters therein stated to be alleged upon information and belief, and that as. to those matters, he believes it to be true.

Sworn to before me, this

— day of January, I9I4.

A....

(Signature, title, etc., of notary.) 


\section{(B) COMPLAINT}

City Court of the City of New York

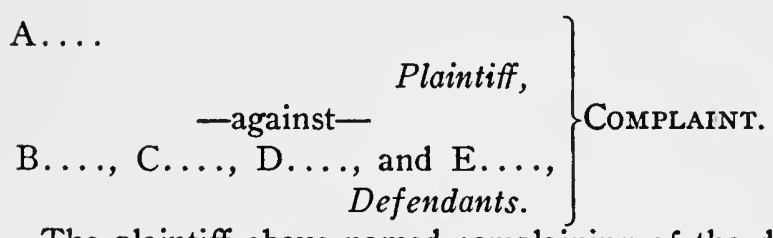

The plaintiff above named complaining of the defendants above named, by ......, his attorneys, respectfully shows to the Court as follows:

FIRST: On information and belief, that at all the times hereinafter mentioned the defendant B... was and still is a corporation organized and existing under and by virtue of the Laws of the State of New York, and was and is the owner of the following real property situate in the Borough of Manhattan, City, County and State of New York, and more particularly bounded and described as follows, to wit:

(Insert detailed description of property by metes and bounds.)

together with the building on said property erected and situate and known as No. ........ Avenue, in said Borough of Manhattan, City of New York.

On information and belief, that at all the times hereinafter mentioned the defendant C.... was and is a corporation organized and existing under and by virtue of the laws of the State of ..... and the defendant D... was and is an officer, to wit: the ......, of the said defendant C.....

SECOND: On information and belief, that on or about the Ioth day of September, 1913, the defendant B.... executed and delivered a lease of and leased a portion of the Sixth floor of the said building erected and situate on the aforesaid premises and owned by said B...., to the defendant C...., and said defendant C..., there- 
upon entered into and has since continued in possession of said leased portion of said premises and was in possession thereof as said tenant at the time when plaintiff was employed by the defendants and the work, labor, services and materials herein referred to were performed and furnished, all as hereinafter stated.

THIRD: That on or about and between the 2oth day of September, I9I3, and the 7th day of November, I9I3, plaintiff, at the special instance and request of the defendants, C.... and D...., and with the express knowledge, consent and approval of the owner, the defendant B...., furnished certain labor and materials in and concerning the said real property and the said building thereon erected and situate as aforesaid, as follows, to wit :

Performed services as an architect in the superintendence and preparation of plans and specifications, the preparation and furnishing of designs for and the furnishing and installation of especially designed electriclighting fixtures, in connection with, and the superintendence and supervision by plaintiff as architect of, certain alterations and improvements in and to, and the outfitting, in accordance with said plans, specifications and designs, of the said portion of said building and premises leased as aforesaid to said defendant C...., by said defendant B..., which said services necessitated and included the supervision and superintendence by plaintiff as architect of all of said work, including superintendence by plaintiff of the making of said alterations in accordance with said plans and specifications, of the choice and installation and furnishing of said fixtures, and of all the details of the improvements and work herein referred to.

FOURTH: That said services, labor and materials aforesaid exclusive of the designing and furnishing and superintendence of the installation of the electric-lighting fixtures herein referred to, were reasonably worth 
the sum of ...... Dollars, which said sum the defendants, B.... and C...., duly promised and agreed to pay to plaintiff therefor; that the preparation of designs for and the furnishing and installation and superintendence of the furnishing and installation of said electric-lighting fixtures, and the said fixtures themselves, were reasonably worth the additional sum of ...... Dollars, which said sum said defendants, B... and C..., duly promised and agreed to pay plaintiff therefor.

FIFTH: That plaintiff has duly performed and fulfilled all the work, conditions and covenants of said contract and agreement on his part to be performed but that no part of said sum of ...... Dollars and no part of said sum of ...... Dollars has been paid and that the whole of each of said sums is now justly due and owing from the defendants to plaintiff.

Sixтн: That the labor and materials performed and furnished and herein referred to, were actually used in and upon and for the improvement of the said property and building aforesaid and that said building and property have been enhanced in value thereby.

Seventh: That on the - day of January, I9I4, and within ninety days after the completion of the contract above set forth, the plaintiff filed a notice of lien in writing in the clerk's office of the County of New York, State of New York, the County in which the property aforesaid against which a lien is asserted is situated, on and against the said real property for the aggregate amount of and sum due to plaintiff for said labor and materials aforesaid, to wit: the sum of ...... Dollars; that said notice of lien contained the name of the owner of said real property against whose interest the lien was claimed and the nature of his interest, the name of the person and corporation by whom plaintiff was employed and to whom and to which he furnished the labor and materials and against whose interest the lien was claimed, the labor performed, materials furnished, 
and the agreed prices thereof, the amount unpaid, the time when the first and last items of work and materials were performed and furnished, and also a description of the property to be charged with the lien in all ways sufficient for identification; that said notice of lien was duly verified and complied in all respects with the requirements of the statutes in such case made and provided, and that on the — day of January, I9I4, said lien was duly entered and docketed by said clerk in the lien docket kept in his office; that a copy of said notice of lien is hereto annexed and marked Exhibit $\mathrm{A}$ and made a part of this complaint.

EIGHTH: On information and belief, that on the day of January, I9I4, and after filing his notice of lien as hereinbefore set forth, plaintiff caused copies of said notice to be and the same were duly served upon the defendant B..., the owner of said building and property aforesaid, and the defendants, C... and D..., respectively.

Ninth: That no other persons have filed liens against said property "nor have subsequent liens or claims by judgment, mortgage or conveyance, except the defendant E...., which is the holder of a mortgage on said premises dated ....., and due ....., for the sum of ..... Dollars.

Tenth: That no other action or proceeding has been brought or commenced or is pending at law or otherwise upon the debt hereinbefore referred to or to enforce any of the rights and obligations hereinbefore set forth, or to recover said debt or any part thereof, and that no part of said debt or of the amount herein claimed has been paid or collected.

WHEREFORE, plaintiff demands judgment:

I. That the priority of all liens and claims on said property be determined and the rights of the respective parties hereto be duly adjudicated. 
2. That he be adjudged to have a lien on said property for the sum of ...... Dollars.

3. That the defendant B..., and all persons claiming under it be foreclosed of all equity of redemption or other interest in said premises.

4. That the interest in said premises of the defendants, B.... and C...., be sold as provided by law and that from the proceeds of such sale the plaintiff be paid the amount of his lien as aforesaid and interest thereon from the 7 th day of November, I9I3, together with the costs of sale and the costs of this action.

5. That plaintiff have personal judgment against the defendants, B..., C.... and D..., and each of them, in the sum of ..... Dollars, together with interest thereon from said November 7 th, I9I3, and for any deficiency that may remain due him after such sale.

6. That plaintiff may have such other or further judgment, decree, order or adjudication as may be necessary to protect his rights in the premises or as may to the Court seem just and proper.

\section{Attorneys for Plaintiff, Office and Post office address, No. 2 Rector Street, Borough of Manhattan, New York City.}

\section{$\left.\begin{array}{l}\text { State of New York } \\ \text { County of New York }\end{array}\right\}$ ss.}

A...., being duly sworn, deposes and says:

That he is the plaintiff in this action; that he has read the foregoing complaint and knows the contents thereof and that the same is true of his own knowledge, except as to the matters therein stated to be alleged upon informa- 
tion and belief and that as to those matters, he believes it to be true.

Sworn to before me this

..... Day of ....., I9r4.

(Notary's signature, title, etc.)

A. . . . .

(Exhibit A. annexed)

\section{NOTICE OF LIEN (A) AND COMPLAINT (B)}

(where work performed has been in connection with private residence.)

\section{(A) NOTICE OF LIEN}

To the Clerk of the County of Westchester, State of New York:-

TAKE Notice, that I, A...., residing at the City of ...... County of ...... and State of ....., with offices at No. ...... Broadway, in the Borough of Manhattan, City and State of New York, have and claim a lien for the principal and interest of the value and agreed price of the labor and materials hereinafter mentioned and the disbursements hereinafter mentioned, upon the real property and upon the improvements hereinafter mentioned, pursuant to the Lien Law and the Acts amendatory thereof and supplemental thereto, and I do further state and allege, as follows, viz.: that

I. The name of the owner of the real property against whose interest a lien is claimed, is, on information and belief, B..... Her address is No. ...... Street, Yonkers, New York. A lien is likewise claimed against the fee of said property, and the interest therein, if any, of C..., all as hereinafter stated.

II. The name of the persons by whom I was employed and to whom I furnished the labor and materials are B...., and C..., the husband of said B.... The 
address of each of said persons is No. ..... Street, Yonkers, New York.

III. The labor performed and materials furnished and the agreed price thereof are as follows, to wit:

Architectural services in the matter of the erection upon the premises described in paragraph VI hereof of a residence for said $\mathrm{B} . .$. and $\mathrm{C} . .$. , consultations regarding, and the preparation of all plans and specifications therefor; general and detailed consultations with said B.... and C.... in regard to and personal and detailed supervision on said premises of, the erection, construction and completion of said residence and building thereon; superintendence of all construction work, and general supervision and superintendence of all work in the matter of the erection of said residence in accordance with the said plans and specifications, including all changes, alterations and additions.

Said services were performed at the request of said B.... and C.... and upon the terms, both as to payment, agreed price and charges, which are set forth and appear in the contract, a copy of which is hereto annexed and marked Exhibit I and made a part hereof. The work on said premises is entirely performed, the building is completed and the final architect's certificate has been issued. In addition to the labor performed as aforesaid, necessary disbursements have been paid out by me in connection with said labor and services, in the amount of $\$$.......

IV. The amount unpaid and owing to me for such labor aforesaid is $\$ \ldots .$. at the time of filing this notice, and for such disbursements aforesaid $\$ . .$. , all as more fully appears from the statement of account hereto annexed and marked Exhibit II. Such labor was and is reasonably worth and of the reasonable value of said sum of $\$ \ldots . .$.

V. On information and belief, the time when the first item of work was performed was the ..... day of 
August, r909. The time when the last item of work was performed was the ..... day of May, I9rr. Ninety days have not elapsed, dating from the last item of work performed, for which this lien is claimed.

VI. On information and belief, the property subject to this lien and upon which I claim a lien, is more particularly bounded and described as follows, to wit :-

(Take in detailed description of property by metes and bounds with diagram if practicable.)

VII. This lien is claimed upon the fee of said premises and upon all the improvements and buildings thereon made or erected, together with any and all appurtenances thereto, and against any and all interest of said B... and C.... and either and both of them, in and to and concerning said premises and the said improvements and appurtenances. Said labor and services were performed and materials furnished, as hereinbefore stated, at the request of said $B . .$. and $C . .$. and with their knowledge and consent, and under and pursuant to the said express contract and agreement between the undersigned lienor and said B... and C..., a copy of which is hereto annexed and marked Exhibit I, and made a part hereof as aforesaid.

VIII. All the labor for which this lien is claimed has been actually furnished, completed and performed, and all said labor was performed in the manner and for the purposes herein set forth and for the improvement of the said real property hereinbefore described, and the undersigned lienor has performed and complied with each and all of the covenants and conditions by him to be performed and complied with under the terms of said contract.

Dated, New York, N. Y., May -, I9II.

A.....

Lienor. 
State of New York

COUNTY OF NEW YORK $s$.

A...., being duly sworn, says that he is the claimant and lienor mentioned in the foregoing notice of lien; that he has read said notice and knows the contents thereof; and that the same is true of his own knowledge, except as to the matters therein stated to be alleged upon information and belief, and that as to those matters he believes it to be true.

Sworn to before me, this

— day of May, I9II.

(Notary's signature, title, etc.)

A......

(Annex Exhibit.)

(B) COMPLAINT

New York Supreme Court, County of Westchester A......,

B..., C.... and D...., $\underset{\text { Defendants. }}{\text { against- }}\}$ ComplainT.

The plaintiff above named, for his complaint in the above entitled action, by ...... his attorneys, alleges and respectfully shows to the Court:

First: On information and belief: that at all the times hereinafter mentioned, the defendant B... was and still is the owner of the following real property, situate in the City of Yonkers, in the County of Westchester and State of New York, and more particularly bounded and described as follows, to wit:-

(Insert detailed description by metes and bounds.)

SECOND: On information and belief, that the de- 
fendant C.... is the husband of said defendant B...., and that the defendant D... is the holder of a mechanic's lien against the above mentioned premises and the interest therein of said B.... which lien is in the amount and of the character specified in the paragraph hereof designated Seventh and that said D... is made a party hereto accordingly.

THIRD: That on or about the Ist day of August, I909, plaintiff and the defendants, B... and C...., above named, duly made and entered into a contract and agreement in writing, a copy of which is hereto annexed and marked Exhibit $A$ and made a part hereof, wherein and whereby the said defendants, B.... and C...., duly agreed to employ, and did employ, plaintiff as architect to consult with them regarding and to prepare and revise sketches and specifications and plans and drawings for and personally to superintend and supervise the erection of a residence and building to be erected by said two defendants in accordance with and pursuant to said plans and specifications upon the said above described premises, and that in and by said agreement and contract it was mutually covenanted and agreed between plaintiff and said defendants, B.... and C...., that in consideration of the premises and of the plaintiff's agreeing to undertake and perform and undertaking and performing said work and preparing and furnishing said plans and sketches and drawings and supervising and superintending the erection of said residence and building, said defendants, B... and C...., would pay and they agreed to pay to plaintiff for his said services, and would, and did agree to, reimburse him for the disbursements and expenses incurred by him and his employees and representatives, the sums and in the manner and upon the terms and in the amounts more specifically set forth and appearing in said contract hereto annexed and made a part of this complaint and marked Exhibit $A$, as aforesaid; that in and by said contract and agree- 
ment it was further and specially mutually covenanted and agreed between plaintiff and said defendants, B... and C...., that plaintiff should receive from and be paid by the said defendants, B... and C...., and said two defendants did duly promise and covenant and agree to pay plaintiff, for his said services and plans and specifications and drawings, in the manner and upon the terms and conditions as to time of payment set forth in said contract, that is to say, one-fifth $(1 / 5)$ of plaintiff's total commissions upon the completion of the sketches for said residence, two-fifths $(2 / 5)$ thereof upon the completion of the working drawings and specifications, and the balance thereof from time to time as the work should progress, and in any event, and not later than forthwith upon the completion of said building, an amount equal to six $(6 \%)$ per centum of the amount of the contract price and authorized extras for the erection of said residence and building on said premises above described, together with all reasonable and proper reimbursement for, and the reasonable value of, all extra work done on the said drawings and plans and specifications, together with the amount of plaintiff's traveling expenses and the traveling expenses of his representatives and employees.

FOURTH: That plaintiff did and has duly performed for said defendants, B.... and C..., all the work and duly furnished all the materials provided for in said contract, and that said work was performed and said materials were furnished for and actually used in the improvement of the said real property and premises hereinbefore described and the erection of said residence and building thereon and that said property and building have been enhanced in value thereby; that plaintiff has duly fulfilled and performed all of the conditions, covenants and agreements of said contract and agreement on his part to be performed and in the manner and within the time therein provided and specified, and that 
the last item of work was performed and said residence and building and work completed on the ..... day of May, I9I I that said contract price and authorized extras for the erection of said residence and building amounted to the sum of $\$ \ldots \ldots$; that six $(6 \%)$ per centum thereof amounts to the sum of $\$ \ldots . .$. ; that extra work was necessarily performed by plaintiff on . said drawings and specifications and plans and in superintending the construction of said building and at the special instance and request of said defendants, B.... and C...., of the reasonable value and which was and is reasonably worth the sum of $\$ \ldots . .$. ; that said necessary traveling expenses of plaintiff and his employees and representatives amounted to the sum of $\$ \ldots \ldots$; making an aggregate total amount of $\$ \ldots \ldots$ which amount became due and owing to plaintiff from said defendants, B.... and C...., prior to the commencement of this action, pursuant to the provisions of said contract and agreement between them; that no part of said sum has been paid, though payment thereof was heretofore and before the commencement of this action duly demanded, except the sum of $\$ . . .$. and that heretofore and prior to the commencement of this action, the balance of said sum of $\$ \ldots .$. , to wit, the sum of $\$ \ldots .$. . became and now is justly due and owing from said defendants, B... and C...., to the plaintiff under and pursuant to the terms of said contract and agreement.

Fifth: That on the ..... day of May, I9I I, and within ninety days after the completion of the said contract and work above set forth, and within ninety days after the completion of said residence and building and the last item of work thereon, plaintiff duly filed a notice of lien in writing in the Clerk's office of the County of Westchester, State of New York, in which county the property aforesaid and above described and against which the lien was asserted, is situate, on and against said 
real property and the building and improvements thereon and the interests and estates of said defendants, B.... and C...., in and to said property and said building and improvements, for the said unpaid balance and amount of the labor and materials and expenses aforesaid, to wit, the said sum of $\$ . . .$. ; that said notice of lien contained the name of the owner of said real property, to wit, said B...., against whose interest and the interest of said C...., if any, the lien was and is claimed, and the nature of her interest and the nature of the interest of said C.... and the name of the person and persons by whom plaintiff was employed and to whom he furnished the said labor and materials; the labor performed and the agreed price thereof; the amount unpaid; the time when the first and last items of work were performed and furnished, and also a description of the property to be charged with the lien in all ways sufficient for identification; that said notice of lien was duly verified and, on information and belief, complied in all respects with the requirements of the statute in such case made and provided, and was on the ...... day of May, I9I I, duly filed and entered and docketed by said Clerk of said County of Westchester in the lien docket kept in his office; that a copy of said notice of lien is hereto annexed and marked Exhibit $\mathrm{B}$, and made a part of this complaint.

Sixth: On information and belief, that on the said ..... day of May, I9I I, and after the filing of his said notice of lien as hereinbefore set forth, the plaintiff caused a copy of said notice to be and the same was duly served personally upon B... the owner of said premises, and one of the defendants herein, as aforesaid, and also caused a copy of said notice to be and the same was duly served personally upon the defendant C...., the husband of said B..., in manner as is by statute provided.

Seventri: On information and belief, that there are 
no other subsequent liens or claims by judgment, mortgage or conveyance outstanding against said property, except as follows, viz. :

A mechanic's lien, filed by the defendant D...., the contractor by whom said residence was erected, against said B.... and said premises and the interest and estate of said B... therein for $\$ \ldots \ldots$, filed $\ldots \ldots \ldots \ldots$ IgII, in the office of the Clerk of the County of Westchester, State of New York.

EIGHTH: That no other action or proceeding has been brought or commenced or is pending at law or otherwise upon the debt hereinbefore referred to or to enforce any of the rights and obligations hereinbefore set forth, or to recover said debt or any part thereof, and that no part of said debt or of the amount herein claimed has been paid or collected.

Ninth: That plaintiff has duly performed and complied with each and all of the provisions of said contract and agreement on his part to be performed and complied with.

Wherefore, plaintiff demands judgment:

I. That he be adjudged to have a lien on said property for the sum of $\$$.......

2. That the defendants, B... and C..., and each and both of them, and all persons claiming under them, be foreclosed of all equity of redemption or other interest in said premises.

3. That the said premises and the interest in said premises of said B... and C... and each and both of them, be sold as provided by law, and that from the proceeds of said sale the plaintiff be paid the amount of his lien aforesaid and legal interest thereon, together with the expenses of said sale and the costs and disbursements of this action.

4. That plaintiff have personal judgment against the 
defendants, B... and C..., in the sum of $\$ \ldots .$. with legal interest, and for any deficiency that may remain due him after such sale.

5. That the priority of any and all claims by lien judgment, mortgage, or conveyance, or otherwise, outstanding against said property, may be determined and plaintiff decreed to have a prior lien on said property, and that plaintiff may have such further judgment, decree or order as may be necessary to protect his rights in the premises, and such other and further relief as to the Court may seem just and proper.

Attorneys for Plaintiff,

Office and post office address,

No. 2 Rector Street,

Borough of Manhattan, New York City.

$\left.\begin{array}{l}\text { State of New York } \\ \text { County of New York, }\end{array}\right\}$ ss.

A... being duly sworn, deposes and says: that he is the plaintiff named in the foregoing complaint; that he has read said complaint and knows the contents thereof, and that the same is true of his own knowledge, except as to the matters therein stated to be alleged upon information and belief, and that as to those matters he believes it to be true.

Sworn to before me this

..... day of June, I9Ir.

A.....

(Notary's signature, title, etc.)

(Exhibits Annexed.) 


\section{LIS PENDENS-PRIVATE PROPERTY}

New York Supreme Court, County of Westchester $\left.\begin{array}{c}\text { Plaintiff, } \\ \text { B...., C.... against- } \\ \text { and D...., } \\ \text { Defendants. }\end{array}\right\}$ LIS PENDENS. SIR :

Notice is hereby given that an action has been commenced and is now pending in the above named Court by the above named plaintiff against the above named defendants, the object of which action is to foreclose a mechanic's lien, notice of which lien was on the ..... day of May, I9II, duly filed in the office of the Clerk of the County of Westchester, State of New York; and

NotICE is further given hereby that the real property affected by said lien is more particularly bounded and described as follows, to wit:-

(Take in detailed description by metes and bounds and lot, Block and street numbers.)

Dated, New York City, August ......, IgI I.

\section{Attorneys for Plaintiff, Office and post office address, No. 2 Rector Street, Borough of Manhattan, New York City.}

To the County Clerk of the County of Westchester, State of New York.

SIR :

You are hereby directed and requested to index the foregoing notice in and against the names of the follow- 
ing defendants in the above entitled action, that is to say, against the names of the defendants, B.... and C.....

Attorneys for Plaintiff,

Office and post office address, 2 Rector Street,

Borough of Manhattan,

New York City.

\section{NOTICE TO OWNER OF CLAIM}

\section{(Under New Jersey Practice)}

TO RICHARD ROE:-

YOU ARE HEREBY NOTIFIED by the undersigned, that A. B., the contractor with whom you have contracted for the erection of the building and dwelling hereinafter referred to, is justly indebted to me, the undersigned, in the sum of ..... Dollars, for work done and labor performed by me at his request, in erecting and constructing, and for materials furnished by me at his request and used in the erection and construction of, the certain three-story stone and frame residence and dwelling house owned by you, situate, lying and being at the Northeast corner of ..... Street and ...... Avenue, in the City of ......, County of ..... and State of New Jersey, and situate and erected upon the property at said location, which is more particularly bounded and described as follows, to wit: (take in description of property, preferably by metes and bounds), which said residence and dwelling house is mentioned and referred to and described in a certain contract in writing heretofore made and entered into between you and said A. B. and heretofore, and on or about the ..... day of ...... 1914, filed in the office of the Clerk of said County of ......, State of New Jersey, and

YOU ARE HEREBY FURTHER NOTIFIED, that I, the undersigned have demanded from the said A. B. payment of 
the said sum of ..... Dollars so due and owing to me as aforesaid and that he, the said A. B. has failed and refused to make payment of the same or any part thereof; and

I DO HEREBY, THEREFORE, NOTIFY AND REQUIRE YOu to retain the amount of money so due to and claimed by me out of the amount owing by, or due from, you to the said A. B. and, upon your being satisfied of the correctness of my demand, to pay the said sum of ..... Dollars, thereupon and forthwith, to me.

Dated, ...... New Jersey, July Ist, I9I4.

(Signed)

JoHN DOE. 


\section{GENERAL INDEX}

\section{References Are to Sections}

\section{ACCEPTANCE}

of commissions by architect, 4 .

of plans, as affecting architect's compensation, 26, 27.

ACTION and delivery distinguished, 27.

for neglect against architect-burden of proof, 44 . by contractor, when premature, 69 .

\section{ADMISSION}

AGENCY

of architects to practice, 3 .

of architect (see also Architect, Emergency, Extras, Super-

\section{AGREEMENT} intendence), 7-19, 46, 65-66.

between architect and builder,-where improper, 4 .

ALTERATION

of contract terms.

by architect, 9 -II.

by owner as affecting architect's agency, 13 .

\section{AMERICAN}

Institute of Architects, schedule of, as proof of value of services, 37.

Institute of Architects-Standard Documents of (see also APPROVAL Appendix B), 72.

of architect, as affecting lien of subcontractor, 95 .

of architect,-lien action as affected by unreasonable withholding of, 95 .

of City Department as condition precedent to maintenance of mechanic's lien, 96 .

of architect,- -unreasonable withholding of, as ground for damages, II4.

ARBITRATION

provision re certificates as affected by covenant for, 55 . provision as affecting provision for liquidated damages, 70 . agreements, as usurping jurisdiction of courts, 72.

ARBITRATOR architect as, $49,65,66$. power of architect to delegate to partner authority as, I4, 15 .

ARCHITECT relation in general between owner and, $\mathbf{I}$. obligations to public of, $1,3,39$. right of, to plead privilege, 2. 
ARCHITECT—continued

[References Are to Sections.]

disclosure of employer's intentions by, 2.

liability for, 2 .

confidential and trust relations of owner and, I, 3, I4.

good faith required of, 3 , II4.

requirements for admission of, to practice, 3 .

to have no concealed or conflicting interest in contract, 4 .

compensation of, as affected by pecuniary interest in contract, 4 .

agreements between builder and, 4 .

effect of, 4 .

acceptance of commissions by, 4 .

loans by builder to, 4 .

employment by contractor of, 4 .

effect of, 4 .

in dual capacity of architect and contractor, 4 .

assumption of good faith of, 6 .

agency of, importance of, 7 .

express and implied agency of, 8.

agency of,-re extras, 9,54 .

as general agent of owner, 9, Io, II, 54 .

agency of, as limited by contract terms, 9, IO, II, 54 .

modification or change of contract terms by, 9 -II.

agency of, as superintendent, $9-19,46,65-67$.

ratification of changes by owner as affecting, 13 .

limitations on general agency of, II.

power of, to employ or substitute new contractor, II.

certificate of, to comply with form specified, II.

certificate of, as affecting right of builder to recover, 55 .

unreasonable refusal to issue certificate by, 55 , II4.

giving of certificates to subcontractors by, II.

right of, to certify extras strictly construed, II.

not allowed to change materials or construction, II.

authority of, to supervise letting of subcontracts, Ir.

authority of, to employ workmen, II.

right of, to receive notice of assignment of contract, II.

special agency of, I2.

general agency of-as enlarged by special agency, I2.

must exercise special agency with care, I2.

strict construction of special agency of, I2.

delegation of powers in general by, I4.

delegation of authority as arbitrator to partner by, I5.

delegation of authority of, by consent, I5.

care required in delegation of authority by, I6.

power of, to act in emergency, 17.

dangers of implied authority of, 18.

importance of caution in exercise of agency authority by, I9.

precautionary suggestions re agency of, 19 .

important to understand right of, to compensation, 20.

theories of recovery of compensation by, 21. 
ARCHITECT—continued

[References Are to Sections.]

right of, to recover for plans, in absence of special agreement, 22.

right of, to compensation for plans, as affected by conditions specified, 22, 23.

right of, to compensation, as affected by conditions re cost of building, 24-25.

estimate of cost by, 24,25 .

compensation of,

as dependent upon delivery and acceptance of plans, 26, 27.

not provable by custom alone, $28,29$.

as dependent on actual contract, $28,29$.

in competitions, 30 .

as dependent on proof of care and skill, $3 \mathrm{I}$.

as affected by modification of contract, 32 .

as affected by rescission of contract by owner, 33-36.

for preliminary sketches, 33,38 .

computation of value of services, 37 .

as affected by variance between preliminary sketches and working drawings, 38 .

charge schedule of American Institute of Architects, as proof of value of services of, 37 .

duties of owner to, 38 .

general suggestions and rules re compensation of, 38 .

skill required of, in general, 39.

compensation of, as affected by defects in plans, 40.

liability of,

for defects in plans, 40.

for mistakes and negligence re plans, $4 \mathrm{I}-45$.

for defects in plans, as affected by compliance with plans, 43,44 .

for expense of repairs, 45 .

for improper superintendence, 46 .

burden of proof in action for damages for defects in plans and specifications, 44 .

care required of, in superintendence, 46 .

measure of care and diligence in superintendence required of, 46 .

negligence of, a question of fact, 47 .

burden of proof in action to recover damages for negligence of, 48 .

as arbitrator, $49,65,66$.

duties to owner of, in issuance of certificates, 50 .

care and diligence required in issuance of certificates by, 50 .

death of, $5 \mathrm{I}$.

as affecting provision requiring certificate, 66 .

right to plans as between owner and, $\mathbf{5 2}$.

right to plans as between builder and, II5.

right of builder to compensation, as affected by estimates of, 
ARCHITECT-continued [References Are to Sections.]

weight given to testimony and opinion of, 55 .

as supervisor (see also Architect and Superintendence), 66. lien of, 80 .

as affected by superintendence, $8 \mathrm{I}-83$.

New York rule re lien rights of, 82,84 .

Massachusetts rule re lien rights of, 83,84 .

effect on lien action of unreasonable withholding of certificate by, 95

certificate of, as condition precedent to enforcement of lien, 95 .

enforcement of lien, as affected by collusion between owner and, 97.

rights and liabilities in general of builder and, I I4.

duties to builder of, 3 , II 4 .

summary of points of importance to builder, owner and, I 6 .

ASSIGNMENT

mechanic's lien as affected by general, I04.

ASSUMPTION

of good faith of architect, 6.

ATTACHING

plans and specifications to contract, 62 .

AUTHORITY

of architect,

dangers of implied, 18.

as superintendent, 9-19, 46, 65-67.

to receive notice of assignment of contract, II.

BALANCE

of contract price,-presumption re, upon completion by owner, 68.

\section{BREACH}

of guarantee as affecting right of contractor to recover, 55.

BUILDER (see also Contractor)

good faith required of architect toward, 3, II4.

loans to architect by, 4 .

agreements between architect and, 4 .

right to compensation for extras, of, 54 .

compensation of, 54 .

effect of architect's estimates on compensation of, 54 .

chargeable with notice of contract provisions, 54 .

recovery of, as dependent upon approval of, and issuance of certificate by, architect, 55 .

recovery by, upon completion of work by owner, 55 .

right of, to plans,

as against owner, 57 .

as against architect, II5.

mutual liabilities of owner and, 56 .

completion by owner upon failure of, 68 .

collusion of architect and owner in withholding certificate no

bar to enforcement of lien by, 97. 
BUILDER-continued

[References Are to Sections.]

suspension of work by mutual consent, as affecting recovery of compensation by, 69.

when action by, premature, 69 .

lien rights of, 89-105.

right of, to lien dependent on performance, $9 r$.

substantial performance by, as supporting lien, 92.

effect of delay upon lien of, 93, 94 .

lien of, as affected by architect's approval, 95 .

rights and liabilities of architect and, II4.

refusal of architect to issue certificate as basis for action for damages by, II 4 .

summary of points of importance to architect, owner and, II6. BUILDING CONTRACT (see Contract).

BURDEN

of proof in action for damages for defects in plans and specifications, 44.

of proof in action for damages for negligence or want of skill of architect, 48.

CARE

of proof in lien action, where architect's approval is withheld, 95.

required in delegation of authority by architect, 16.

proof of, as affecting right of architect to recover, 31 .

degree of, required of architect in superintendence, 46 .

CERTAINTY

required in contract, 62 .

CERTIFICATE

of architect to subcontractors, II.

of architect to comply with form specified, II.

duties of architect to owner in issuance of, 50.

care required in issuance by architect of, 50 .

of architect, importance of, 55 .

unreasonable refusal of architect to issue, 55 .

proof of waiver of, 55 .

recovery by builder, where error of law is result of failure of architect to give, 55 .

effect of final, 55 .

as evidence of amount due from owner to contractor, 55 .

as affected by covenant for arbitration, 55 .

provisions for, enforcible for benefit of contractor, as well as owner, 55 .

death of architect as affecting provision for, 66 .

issuance by architect of,

as condition precedent to recovery by contractor, 55 .

as condition precedent to maintenance of lien action, 95 .

effect of collusion, 97.

waiver by owner, 98 .

as evidence of performance, to support lien, 99 .

duties of architect to contractor re issuance of, II 4 . 
CERTIFICATION

[References Are to Sections.]

of extras by architect strictly construed, II.

CHANGE

of contract terms by architect, 9-1 I.

in specifications, - contract provision that consent of architect is necessary to, 67 .

in ownership, as affecting mechanic's lien, I02.

CHANGES

approved by owner, as affecting architect's agency, I3.

CITY

Department,-approval of as condition precedent to enforcement of lien, 96 .

\section{CLAIMS}

priority of, in mechanic's lien, II3.

COLLUSION

between owner and contractor, 38 .

between architect and owner, in withholding certificate, no COMMISSIONS bar to enforcement of lien, 97.

acceptance by architect of, 4 .

COMPENSATION

of architect (see also Architect, Mechanic's Lien, Plans, Preliminary Sketches, Recovery).

as affected by pecuniary interest in contract, 4 .

theories of recovery by architect of, 2 I.

important to understand right of architect to, 20.

right of architect to, in absence of special agreement, 22. as dependent upon delivery and acceptance of plans, 26,

27.

not sustained by proof of custom, alone, 28, 29 .

for plans submitted in competitions, 30 .

as dependent on proof of care and skill, 3 r.

as affected by modification of contract, 32 .

for preliminary sketches, 33,38 .

as affected by rescission of contract by owner, 33-36.

computation of value of services, 37 .

schedule of charges of American Institute of Architects, as evidence of value of services, 37 .

as affected by variance, between preliminary sketches and working drawings, 38 .

general suggestions and rules re, 38 .

as affected by defects in plans, 40 .

of builder (see also Builder, Contractor, Damages, Mechanic's Lien, Recovery).

as affected by modification of contract, 54 .

effect of estimates by architect on, 54 .

occasioned by omission or act of owner, 54 .

as dependent upon approval of and issuance of certificate by architect, 55 . 
COMPETITIONS

[References Are to Sections.] right to compensation for plans submitted in, 30 .

COMPLETE right to compel owner to, 35 .

COMPLETION

of contract by owner, 68 .

presumption re unpaid balance of contract price, upon, 68 .

COMPLIANCE

with plans as affecting right of action against architect for defects, 44 .

COMPUTATION

of value of services of architect, 37 .

CONCEALED

interest of architect in contract, 4.

CONDITION

precedent,- - architect's certificate a, to maintenance of lien, 95 . precedent, delivery and acceptance of plans as, to architect's CONDITIONS right to recover, $26,27$.

of contract-waiver of, 15 .

CONFLICTING

interest of architect in contract, 4 .

CONSENT

suspension of work by mutual, 69 .

of owner, as affecting right to lien, 88, 105.

delegation of authority by architect, by, 15 .

CONSIDERATION

necessity of, in contract, 62 .

CONSPIRACY

between owner and contractor, 38 .

between architect and owner, 97.

CONSTITUTIONALITY

of mechanic's lien legislation, 76 .

CONSTRUCTION

of contract provisions re extras, II.

CONSTRUCTION CONTRACT (see Contract)

CONTRACT

modification or change of, by architect, $9-1$ I.

provisions for extras, in, 9-10, 67.

validity of provisions re extras, in, 67 .

waiver by parties of conditions of, 15 .

modification of, as affecting compensation of architect, 32.

rescission of by owner as affecting compensation of architect, 33,34 .

right to compel owner to complete, 35 .

measure of damages on refusal of owner to complete, 36 .

extension, by implication, of term of, 54 .

effect of fraud on, 56 .

general requisites of construction, 62 .

necessity of consideration for, 62 . 
CONTRACT-continued

[References Are to Sections.]

necessity of certainty in, 62 .

necessity of written, 62 .

for illegal purpose, 62 .

embodied in various instruments, 62 .

incorporation, by reference, of plans and specifications in, 62 .

necessity of attaching plans and specifications to, 62 .

various statutory provisions re, 63 .

distinction between void and illegal, 64 .

validity of provision requiring consent of architect to change in, 67 .

requirement of owner's consent for sub-letting of, 67 .

waiver by owner of terms of, 67 .

provisions re liquidated damages, 70.

not to usurp jurisdiction of courts, $7 \mathrm{I}, 72$.

mechanic's lien as dependent upon, 79 .

lien by, 86.

provisions, as affecting lien rights of subcontractor, ino.

effect upon lien rights of filing or recording of, 112 .

CONTRACTOR (see also Builder)

good faith required of architect toward, 3, II4.

loans to architect by, 4.

as superintendent of his own work, 4.

architect acting as, 4

employment of architect by, 4 .

employment or substitution by architect of new, II.

compensation of, 54 .

effect of architect's estimates on compensation of, 54 .

chargeable with notice of contract provisions, 54 .

recovery for extras by, 54, 67 .

recovery by, where architect's refusal to issue certificate is unreasonable, 55 .

certificate, as evidence of amount due from owner to, 55 .

breach of guarantee, as affecting recovery by, 55 .

certificate provisions enforcible for benefit of, 55 .

right of owner to recover damages from, 56 .

obligations of owner to, 56 .

obligations to owner of, 56 .

right of, to plans,

as against owner, 57 .

as against architect, II5.

liability of, for work of subcontractor, 58 .

recoupment from subcontractor by, 59 .

necessity of substantial performance by, 6r.

importance of provisions re extras, to, 67 .

completion by owner upon failure of, 68 .

suspension of work by mutual consent, as affecting recovery of compensation by, 69 .

when action by, premature, 69 .

lien rights of, 89-105. 
CONTRACTOR-continued

[References Are to Sections.]

right of to lien dependent upon performance, $9 \mathbf{r}$.

substantial performance by, as supporting lien, 92 .

effect of delay upon lien of, 93,94 .

lien of, as affected by architect's approval, 95.

collusion between architect and owner in withholding certificate no bar to enforcement of lien by, 97.

lien of subcontractor as affected by failure of, to complete, 109. necessity, and effect upon lien rights, of filing or recording contract between owner and, 112 .

rights and liabilities of architect and, $\mathrm{II}_{4}$.

refusal of architect to issue certificate as basis for action for damages by, I I 4 .

summary of points of importance to architect, owner and, II6. CORPORATIONS

COST

as lienors, 100 .

of building, as affecting architect's right to compensation, 24, 25.

estimation by architect of, 24,25 .

COURTS

tendency of, in enforcement of provision re extras, 67 . CUSTOM

as affecting right of architect to compensation, 28, 29.

DAMAGES (See also Architect, Contractor, Owner)

measure of, on refusal of owner to complete, 36 .

liquidated, 70 .

arbitration provision as affecting provision for liquidated, 70 .

right of builder to, for refusal of architect to issue certificate, II 4.

for defects in plans, 40.

for improper workmanship, 56.

burden of proof in negligence action against architect for, 48 .

DANGERS

of implied authority of architect, I8.

DEATH

of architect, $5 \mathrm{I}$.

as affecting provision requiring certificate, 66 .

of owner as affecting mechanic's lien, I03.

\section{DEFECTS}

in plans,-liability of architect for, 40 .

DEGREE

of care and diligence required of architect as superintendent, 46.

DELAY

effect of, upon lien of contractor, 93, 94.

DELEGATA POTESTAS NON POTEST DELEGARE, r4, 15.

DELEGATION

of authority by architect, I4, 15 .

by consent, 15 .

due care required in, 16. 
[References Are to Sections.]

DELAGATUS NON POTEST DELEGARE, 14, 15.

DELIVERY

and acceptance of plans as affecting architect's right to compensation, 26, 27.

and acceptance distinguished, 27.

DILIGENCE

degree of, required of architect in superintendence, 46 .

DISCLOSURE

of employer's intentions by architect, $\mathbf{2}$.

DISTINCTION

between void and illegal contracts, 64 .

DOCUMENTS

the "Standard Documents" of the American Institute of Architects (see also Appendix B), 72.

DRAWINGS (see also Compensation, Preliminary sketches).

contract provisions requiring consent of architect, to justify

EMERGENCY departure from specifications or, 67 .

powers of architect in, 17.

EMPLOYEES of subcontractor,-lien rights of, irr.

EMPLOYMENT

ERROR of workmen by architect, II.

of law,-recovery by builder where failure to give certificate is due to, 55 .

ESTIMATES

of architect, as affecting right of builder to compensation, 54 .

ESTIMATION

of building cost by architect as affecting liability of owner,

ESTOPPAL $24,25$.

of owner from claiming architect's acts improper, 5 .

of owner from claiming exceeding of agency powers by archi-

EVIDENCE tect, 13 .

certificate as evidence of performance in general, 55 .

certificate as evidence of performance to support lien, 99 .

schedule of charges of American Institute of Architects, as,

EXCEEDING

of agency powers by architect (see also Architect), when

EXPRESS

owner estopped from claiming, 13 .

agency of architect, 8.

EXTENSION

of contract term by implication, 54 .

EXTRAS (see also Architect, Builder, Contractor, Owner)

rights and liabilities of architect re, 9, 54 .

right of architect to certificate for, strictly construed, II. 
EXTRAS-continued

[References Are to Sections.]

right of builder to recover for, 54 .

occasioned by omission or act of owner, 54 .

importance to owner and contractor of contract provisions re, 67.

tendency of courts in enforcement of provisions for, 67 .

order for, by implication, 67 .

validity of provisions in contract for, 67 .

FAILURE

of builder-completion by owner upon, 68 .

FILING

of contract and specifications as affecting lien rights, II2.

FINAL

FIRE

certificate-effect of, 55 .

FIXTURES

FORM right to mechanic's lien for lighting, 87.

specified-certificate of architect to comply with, II.

FORMS (See Special Index to Forms, page 314).

FRAUD

effect of, on contract, 56 .

GENERAL

assignment, as affecting mechanic's lien, 104.

GOOD FAITH

required of architect,

toward owner, 3.

toward builder, 3 , II 4 .

of architect assumed, 6.

GUARANTEE

right of contractor to recovery, as affected by breach of, 55 . HISTORY

of mechanic's lien legislation, $\mathbf{7 4}, 75$.

ILLEGAL

contract for purpose which is, 62 .

contract as distinguished from void contract, 64 .

IMPLICATION

extension of term of contract by, 54 .

IMPLIED

agency of architect, 8.

authority of architect, $\mathbf{1 8 .}$

IMPROPER dangers of, I8.

agreement between architect and builder, 4 . superintendence, liability of architect for, 46 .

INSTITUTE

of Architects,-American,-charge schedule of as proof of value of services, 37 . 
INTEREST [References Are to Sections.]

conflicting, - of architect in contract, 4

ISSUANCE

of certificate,-duties of architect,

to owner in, 50 .

to builder in, II4.

JURISDICTION

of courts,

contract not to usurp, 71,72 .

arbitration agreements, as usurping, 72.

LIABILITIES

of architect, owner and contractor (see Architect, Builder, Contractor, Compensation, Lien, Owner, Plans).

LIEN (see Mechanic's Lien)

\section{LIGHTING}

fixtures, right to mechanic's lien for, 87 .

LIMITATION

of agency of architect, IO-I9.

LIQUIDATED

damages, 70 .

legality of provision for, as distinguished from penalty, 70.

LOANS

arbitration provision as affecting provision for, 70 .

by builder to architect, 4 .

MAINTENANCE

of lien,-approval by City Department as condition precedent to, 96.

MASSACHUSETTS

right of architect to lien in, 83,84 .

MATERIAL-MEN

of subcontractor,-lien rights of, III.

MEASURE

of damages on refusal of owner to complete, 36 .

of care and diligence required of architect in superintendence, 46.

MECHANIC'S LIEN

as dependent on state statutes, 73,85 .

definition of, 73 .

history of, 74,75 .

constitutionality of, 76 .

as statutory remedy, 77 .

imposes no personal liability, 78 .

necessity of contract to enforcement of, 79 .

of architect, in general, 80, 8r.

importance of superintendence in establishment of architect's right to, $8 \mathrm{I}-83$.

of architect under New York doctrine, 82, 84. 
MECHANIC'S LIEN-continued

[References Are to Sections.] of architect under Massachusetts doctrine, 83, 84 . importance of statutory provisions in consideration of, 85 . by contract, 86 . for lighting fixtures, 87 . consent of owner, as affecting right to, 88 . rights of contractor in general, 89-90. as dependent on performance, $9 \mathrm{I}$. the doctrine of substantial performance, 92 . as affected by delay, 93, 94 .

as dependent on architect's approval, 95 . certificate of architect as condition precedent to enforcement of, 95 .

approval of City Department as condition precedent to enforcement of, 96 .

enforcible where certificate of architect withheld through collusion with owner, 97.

waiver of production of certificate by owner as affecting, 98 . certificate as evidence of performance to support, 99.

right of corporations to enforce, I00.

effect of destruction of building by fire on, ror.

as affected by change in ownership, 102 .

effect of death of owner upon, I03.

as affected by general assignment, 104 .

consent of owner as affecting right to, 105 .

of subcontractor,

nature of, 106.

Pennsylvania doctrine re, 107.

New York doctrine re, 108. subrogation, 108.

failure of contractor to complete as affecting right of subcontractor to, I09.

contract provisions as affecting rights of subcontractor to, I IO.

rights of employees and material-men of subcontractor to, III.

effect of filing or recording contract and specifications upon, I12.

necessity of filing specifications with contract, II2. "Stop Notice" under New Jersey practice, II 2. priority of claims in, 113 .

MISTAKES in plans, $4 \mathrm{I}-45$.

MODIFICATION

of contract by architect, 9-I I.

of contract, as affecting compensation of architect, 32.

MUTUAL

consent-suspension of work by, 69 . 
NEGLIGENCE

[References Are to Sections.]

of architect-a question of fact, 47. NEW

or lack of skill of architect-burden of proof in action for, 48 .

contractor, employment by architect of, Ir.

NEW YORK

right of architect to lien in, 82,84 .

doctrine re lien of subcontractor, 108 .

NOTICE

of assignment of contract-architect without authority to receive, Ir.

builder chargeable with notice of contract provisions, 54 .

Stop, under New Jersey practice, II 2 .

OBLIGATIONS

of architect, owner, and contractor (see Architect, Builder, Contract, Contractor, Damages, Mechanic's Lien, Owner, Plans, Preliminary Sketches).

\section{OMISSION}

by owner, as affecting builder's right to compensation for extras, 54 .

OPINION

of architect-weight of, 55 .

\section{OWNER}

relation in general between architect and, $\mathrm{I}$.

estoppel of, from claiming architect's acts are improper, 5 .

liability of, where new contractor employed by architect, II.

not bound by receipt of notice of assignment of contract by architect, II.

estoppel of, from claiming exceeding of agency powers by architect, $\mathrm{I} 3$.

alterations or changes approved by, as affecting architect's. agency, 13 .

relations of architect to, based on trust and confidence, I-3, I4 liability to architect of, for plans, in absence of special agreement, 22.

as affected by conditions specified, 22,23 .

as affected by conditions re cost of building, 24, 25 .

estimate of cost by architect as affecting liability of, 24, 25 .

rescission of contract by, 33-36.

can not be compelled to complete, 35 .

rights of, against architect for neglect and mistake, 40-43.

burden of proof in action by, against architect for neglect, 44 . right of, to damages for repairs, 45 .

right of, to damages for improper workmanship, 56 .

right of, to plans, as against architect, 52 .

right of, to plans, as against builder, 57 .

extras occasioned by omission or act of, 54 .

architect's certificate, as affecting right of builder to recover against, 55 .

waiver of issuance of architect's certificate by, 55 . 
OWNER-continued

[References Are to Sections.]

liability of, where refusal to issue architect's certificate is unreasonable, 55 .

recovery by builder on completion of work by, 55 .

certificate as evidence of amount due to contractor from, 55 . certificate provisions enforcible for contractor as well as, 55 .

liability of contractor for damages, to, 56 .

obligations to contractor of, 56 .

obligations of contractor to, 56 .

importance of provisions re extras to, 67 .

waiver of contract terms by, 67 .

completion of contract by, 68 .

construction by courts of provision for completion by, 68 .

presumption re unpaid balance of contract price on completion by, 68 .

consent of, as affecting mechanic's lien, 88, 105.

production of certificate in lien action may be waived by, 98 .

mechanic's lien, as affected by death of, I03.

effect on lien rights of filing or recording contract between contractor and, II 2 .

necessity of filing specifications with contract to prevent lien claim against, II2.

summary of points of importance to architect, builder and, II6.

OWNERSHIP

change of, as affecting lien, ro2.

PARTNER

delegation of authority by architect to, 14, I5.

PAYMENT

time of, where no fixed time specified, 60 .

right of architect to (see Architect, Compensation, Plans, Preliminary Sketches).

right of contractor to (see Contractor, Builder, Compensation).

\section{PECUNIARY}

interest of architect in contract,-effect of, 4. PENALTY

as distinguished from liquidated damages, 70 .

PENNSYLVANIA

doctrine re lien of subcontractor, ro7.

PERFORMANCE

as affecting right of contractor to lien, $9 \mathbf{I}$.

doctrine of substantial, 92.

PLANS

right of architect to recover for, $20-25$.

theories of recovery by architect for, 2 I.

right of architect to compensation for, as affected by conditions re cost, $24,25$.

right of architect to compensation for, as dependent upon delivery and acceptance, $26,27$. 
PLANS-continued

[References Are to Sections.]

delivery and acceptance of, distinguished, 27.

defects in,

as affecting compensation of architect, 40.

liability of architect for, 40 .

mistakes and negligence re, 4I-45.

compliance with, as condition precedent to recovery of damages from architect for defects, $43,44$.

right of owner to,

as against architect, $\mathbf{5 2}$.

as against builder, 57 .

right of builder to,

as against owner, 57 .

as against architect, II5.

right of architect to,

as against owner, 52 .

as against builder, II5.

incorporation of plans and specifications in contract, by reference, 62 .

where must be attached to contract, 62 .

PRECAUTIONARY SUGGESTIONS

re agency of architect, 19.

re compensation of architect, 38 .

in general, 116.

PRECEDENT

certificate of architect, as condition precedent to maintenance of lien, 95.

PRELIMINARY SKETCHES

right to compensation for, 33,38 .

variance between working drawings and, 38 .

PREMATURE

action by contractor, 69 .

PRESUMPTION

re unpaid balance of contract price on completion by owner, 68.

PRIORITY

of lien claims, II3.

PRIVILEGE

right of architect to plead, 2.

PRODUCTION

of certificate,-necessity of, 55 .

in lien action, 95 .

PROOF

waiver of, 98 .

of skill and due care as affecting right of architect to recover, 3 I.

PUBLIC

duties of architect to, 3 .

QUESTION

of fact-negligence of architect $a, 47$. 
RECORDING

[References Are to Sections.]

of contract as affecting lien rights, 112.

RECOUPEMENT

by contractor from subcontractor, 59 .

RECOVERY

of compensation by architect,

theory of, $2 \mathrm{I}$.

in absence of special agreement, 22.

as affected by special conditions, 22-25.

as affected by proof of exercise of due care, $3 \mathrm{r}$.

by builder, where failure to give certificate due to error of law, 55 .

by architect, in general (see Architect, Compensation, Mechanic's Lien, Plans, Preliminary Sketches).

by contractor, and subcontractor in general (see Contractor, Subcontractor, Builder, Compensation, Damages, Mechanic's Lien).

by owner, in general (see Owner, Damages).

REFERENCE

incorporation of plans and specifications in contract by, 62.

REFUSAL

by owner to complete,--measure of damages on, 36 .

of architect to issue certificate,

as bar to recovery by contractor, 55 .

as affecting lien of contractor, 95 .

as justifying action for damages by contractor, II4.

RELATIONS

of architect and owner (see Architect, Owner).

REPAIRS

liability of architect for expense of, 45 .

REQUIREMENTS

for admission of architects to practice, 3 .

REQUISITES

general, of construction contract, 62 .

RESCISSION

of contract by owner, 33-36.

RIGHTS

of architect, owner and contractor (see Architect, Owner, Builder, Contractor, Compensation, Damages, Mechanic's Lien, Plans).

SERVICES

of architect-computation of value of, 37 .

\section{SKETCHES}

right to compensation for preliminary, 33,38 .

variance between working drawings and preliminary, 38 .

SKILL

proof of, as affecting right of architect to recover, $3 \mathrm{r}$. 
SPECIAL AGENCY

[References Are to Sections.]

of architect, 12 .

to be carefully exercised, 12.

strictly construed, I2.

\section{SPECIFICATIONS}

incorporation of, in contract by reference, 62 .

must be attached to contract, when, 62 .

contract provision that consent of architect necessary to authorize departure from, 67.

necessity of filing, with contract to protect owner from lien, II2.

STANDARD DOCUMENTS

of the American Institute of Architects (see also Appendix B), 72 .

STATE

statutes re contract, 63 .

statutes re liens, importance of, 85 .

\section{STATUTORY}

provisions re contract, 63 .

provisions, importance of, in consideration of lien rights, 85 .

"Stop Notice" under New Jersey practice, II 2.

\section{STRICT}

construction of right to architect's certificate, II.

construction of agency of architect, 9-12, 54 .

\section{SUBCONTRACTOR}

certificates of architect to, II.

liability of contractor for work of, 58 .

recoupement by contractor from, 59 .

nature of lien of, 106 .

Pennsylvania doctrine re lien of, 107.

the theory of direct lien, 107.

New York doctrine re lien of, 108.

the theory of subrogation, 108.

failure of contractor to complete as affecting lien rights of, 109.

contract provisions as affecting lien rights of, IIo.

rights of employees and material-men of, III.

recording contract as affecting lien rights of, II2.

filing or recording specifications and contract as affecting lien rights of, II2.

remedy of, by "Stop Notice," II2.

SUB-LETTING

of contract, as dependent upon owner's consent, 67 .

\section{SUBROGATION}

lien of subcontractor by, 108 .

\section{SUBSTANTIAL}

performance, necessity of proof by contractor of, 6r.

performance, - what constitutes, $6 \mathbf{r}$. 
SUBSTITUTION

[References Are to Sections.]

of new contractor by architect, II

SUGGESTIONS

re compensation of architect, 39 .

re agency of architect, 19.

in general, for architect, owner and builder, II6.

SUMMARY

of special matters affecting architect, owner and contractor, II6.

SUPERINTENDENCE (see also Architect, Mechanic's Lien)

by contractor of his own work, 4 .

by architect, in general, 9, 19, 46, 65-66.

care and diligence required of architect in, 46 .

liability of architect for improper, 46 .

importance of, in enforcement of mechanic's lien, 8I-83.

SUPERINTENDENT

agency of architect as, 9-19, 46, 65-67.

SUPERVISION

by architect of letting of subcontract, II.

SUPERVISOR

architect as (see also Architect, Superintendence), 66.

SUSPENSION

of work by mutual consent, 69 .

TENDENCY

of courts in enforcing provisions for extras, 67.

TESTIMONY

TIME

of architect-weight of, 55 .

extension of term of contract by implication, 54 .

of payment where no fixed time specified, 60 .

UNPAID

balance of contract price,--presumption re, on completion by owner, 68.

UNREASONABLE

withholding of certificate by architect, 55 .

withholding of architect's approval in lien action, 95.

USURPATION

of jurisdiction of courts by contract, 7I, 72 .

VALIDITY

of contract provisions,

re extras, 67.

re liquidated damages, 70 .

\section{VALUE}

of architect's services, computation of, 37 .

schedule of American Institute of Architects as proof of, 37. 
VARIANCE

[References Are to Sections.]

between preliminary sketches and working drawings, 38 . effect of, 38.

VARIATION

VOID

of contract terms by architect, 9-II.

contract as distinguished from illegal contract, 64 .

WAIVER

of contract conditions, 15,67 .

by owner of issuance of architect's certificate, 55 .

of certificate-proof of, 55 .

by owner of production of certificate in lien action, 98 .

WITHHOLDING

of architect's approval in general,- effect of, 55 .

WORK in lien action, 95 .

suspension of, by mutual consent, 69 .

WORKMEN

supervision by architect of employment of, II.

WRITTEN

. contract,-necessity of, 62 .

\section{INDEX TO FORMS}

\section{[References Are to Pages.]}

Complaints in lien actions, 277, 285.

Lis pendens private property, 292.

Notice to owner of claim against contractor, 293.

Notices of lien in lien actions, 273, 282.

Standard form of, acceptance of subcontractor's proposal, 252. agreement between contractor and owner, 222.

bond, 245 .

certificate of authority to execute contract or bond, $25 \mathrm{I}$. contractor's proposal, with alternative clauses, 254 .

general conditions of the contract, 224.

instructions to bidders, 253.

invitation to submit proposal 252.

subcontract, 247 . 




\section{UNIVERSITY OF CALIFORNIA LIBRARY}

\section{Los Angeles}

This book is DUE on the last date stamped below.

FEB 41980

[aue lihuare Ror'd

IPN? 1980 


\section{;}

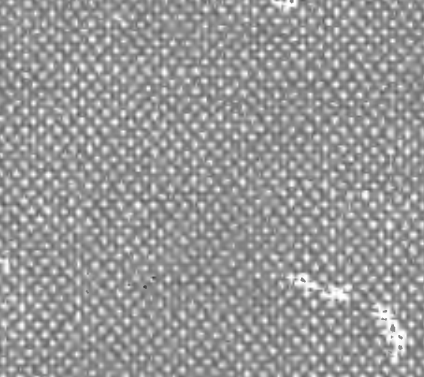

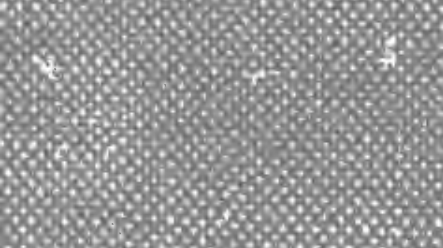

.

$\%$ 